\title{
Shattering the Slave Power: \\ Northern Soldiers Interpret Their Civil War
}

\author{
Peter Clayton Luebke \\ Richmond, Virginia
}

B.A., College of William \& Mary, 2005

M.A., University of Virginia, 2007

\author{
A Dissertation presented to the Graduate Faculty \\ of the University of Virginia in Candidacy for the Degree of \\ Doctor of Philosophy \\ Department of History \\ University of Virginia \\ May, 2014
}


(C) Copyright by

Peter Clayton Luebke All Rights Reserved

May 2014 


\section{Table of Contents}

$\begin{array}{ll}\text { Introduction } & 1\end{array}$

Chapter 1 "For the Union, Constitution, and Enforcement of the Laws":

Pennsylvania and New Jersey Troops Confront the Slave Power

29

Chapter 2 "The Bone and Sinue of the Population": Western Soldiers, Masculinity, and the Fight Against the Slave Power

Chapter 3 "Equal to Any Minstrel Concert I Ever Attended at Home": Union Soldiers and Blackface Minstrelsy as a Strategy of Containment

Chapter 4 "To Transmit and Perpetuate the Fruits of This Victory": Union Regimental Histories and the Slave Power in Immediate Retrospect

Chapter 5 "Bugles of Liberty": Military Order of the Loyal Legion of the United States Remember Their Struggle Against the Slave

Power

Conclusion 


\section{Introduction}

$* * * * * * * * * * * * * * * * * * * *$

The first volume of former Massachusetts Republican senator Henry Wilson's History of the Rise and Fall of the Slave Power in America appeared in 1872. In the exhaustive work, which would eventually span three heavy volumes and cover nearly two thousand pages, Wilson gave a legal, political, and cultural history of how a slaveholding aristocracy in the South had corrupted American democracy, thereby leading to the outbreak of the Civil War. As he explained in his preface, "from the closing months of 1860 to the spring of 1865 , the United States presented to the gaze of mankind a saddening and humiliating spectacle... Violence held its carnival and reaped its bloody harvest." Many "thoughtful men have asked why this Christian nation...was rent and dissevered by fraternal strife. Why was the soil of republican America reddened with the blood of husbands and fathers, sons and brothers, and bathed with the tears of wives and mothers, daughters and sisters?"1

Wilson proposed an answer to that question. In his opinion, a "Slave Power" had sought "to make perpetual its hateful dominion." He explained that "inborn indolence, conjoined with avarice, pride, and lust of power" resulted in the institution of slavery, which "reduced man, created in Divine image, to property." From such base motives, the system of slavery created "a commanding power, ever sensitive, jealous, proscriptive, dominating, and aggressive." For Wilson, the history of American politics charted out the path that the Slave Power had taken to seize control of the institutions of government, how its "Champions" sought "to oppose every interest, every institution, and every

\footnotetext{
${ }^{1}$ Henry Wilson, History of the Rise and Fall of the Slave Power in America, Vol. I (Boston: Houghton, Mifflin and Company, 1872), v.
} 
individual that menaced its paramount sway." ${ }^{2}$ The election of Abraham Lincoln in 1860 as president, for Wilson, marked the first time that the Slave Power faced a setback. The slaveholders, who "for more than two generations...had dictated principles, shaped policies, made Presidents and cabinets, judges of the Supreme Court, Senators, and Representatives...had been beaten." ${ }^{3}$ Reacting precipitously to this check on their power, the slaveholding aristocrats of the South engineered undemocratic conventions to take their states out of the Union. Northerners, unwilling to let the flame of republican liberty go out in the world because of the machinations of such a craven class, sprang to the rescue.

Although Wilson wrote more than a decade after the start of the Civil War, his assessment that a "Slave Power" of some kind had derailed the American experiment had been a widely held idea among the wartime generation. Wilson only offered the most comprehensive and sustained account of it. Foreign critics, such as the economist John Eliot Cairnes, had also fingered a slaveholding oligarchy as the force behind secession and the American Civil War. ${ }^{4}$ But beyond politicians, common men who served in the Union armies thought that white southern aristocrats sought to undermine the Union, and said so in letters home and in their diaries.

For instance, Harris Beecher, who had served with the 114th New York Infantry Regiment during the war, explained in a regimental history, a book aimed at telling the

\footnotetext{
${ }^{2}$ Ibid., v, 1-2, and 17.

${ }^{3}$ Henry Wilson, History of the Rise and Fall of the Slave Power in America, Vol. II (Boston: Houghton, Mifflin and Company, 1874), 704.

${ }^{4}$ J. E. Cairnes, The Slave Power: Its Character, Career, \& Probable Designs: Being an Attempt to Explain the Real Issues Involved in the American Contest (London: Parker, Son \& Bourn, 1862).
} 
families at home what the soldiers had fought for, that "history no where tells us that aristocracy is the parent of a successful revolution." After cataloguing a number of upheavals that had resulted in the overthrow of the old order, he turned to the "American rebellion," which he assessed as "a revolt of the aristocracy" with "no nobler purpose than the enrichment of the privileged classes." ${ }^{5}$ During the Civil War, Capt. Francis Moore of the 2nd Illinois Cavalry found the white populace of the South ignorant. He acidly remarked that "the rulers and leaders, who are the few intelligent and educated, find it much easier to lead and rule the masses if they are kept in ignorance." As a result, the white masses of the South had been "used by dupes by the rich." Despite the damage the war had inflicted upon the nation, Moore found it ultimately salutary in its effects, for "the South will yet come out of her baptism of fire all the better for the scorching" because "slave aristocracy will give way to northern thrift, education, and enterprise."6 Both Beecher and Moore used the Slave Power Conspiracy thesis to explain the Civil War and what they saw during it; while they opined at far shorter length than Wilson, their testimony, and much more like it, demonstrates that soldiers drew upon the idea during the war.

Scholars who have looked at Union soldiers during the Civil War have often given the idea of the Slave Power short shrift in their analyses. Bell Irvin Wiley, in a pioneering study of Union soldiers during the Civil War, focused on the daily texture of

\footnotetext{
${ }^{5}$ Harris Beecher, History of the 114th Regiment, N.Y.S.V. Where it Went, What it Saw, and What it Did (Norwich: J.F. Hubbard, Jr., 1866), 12-15.

${ }^{6}$ The Story of My Campaign: The Civil War Memoir of Francis T. Moore, Second Illinois Cavalry, edited by Thomas Bahde with a foreword by Micahel Fellman (DeKalb: Northern Illinois University Press, 2011), $145,86,163$.
} 
soldiers' lives, what they ate, how they entertained themselves in camps, and how they dealt with the ordeal of combat. Further studies, such as James I. Robertson's Soldiers Blue and Gray deepened Wiley's analysis through a broader consideration of sources. Both Wiley and Robertson largely avoided discussing in detail the ideological motivations of Union troops. ${ }^{7}$

Other historians, more concerned with the ideologies of northern soldiers during the Civil War have mentioned the Slave Power conspiracy thesis, largely in passing. Historians Earl J. Hess, Randall Jimmerson, James M. McPherson, and Reid Mitchell have noted that the idea of the Slave Power impelled many northerners to enlist. All four of these authors pointed to the ways in which the concept helped sustain commitment to the Union cause, but they offered little sustained attention to how the idea persisted throughout the war and how it meshed with the evolution of emancipation as a war aim. Furthermore, these scholars, except for Hess, concerned primarily with the wartime years by necessity avoided discussion of how the Slave Power thesis shaped how soldiers saw the war after it had ended. ${ }^{8}$

\footnotetext{
${ }^{7}$ James I. Robertson, Jr., Soldiers Blue and Gray (Columbia: University of South Carolina Press, 1988); and Bell Irvin Wiley, The Life of Billy Yank: The Common Soldier of the Union (Indianapolis: BobbsMerrill, 1952).

${ }^{8}$ Earl J. Hess, Liberty, Virtue, and Progress: Northerners and Their War for the Union, 2d ed. (New York: Fordham University Press, 1997); Randall Jimmerson, The Private Civil War: Popular Thought During the Sectional Conflict (Baton Rouge: Louisiana State University Press, 1988), 45-46; James M. McPherson, For Cause and Comrades: Why Men Fought in the Civil War (New York: Oxford University Press, 1997), 19; and Reid Mitchell, Civil War Soldiers (New York: Penguin, 1988), 13-14.
} 
In recent years, several scholars have identified how for some soldiers, the prime meaning of the Civil War became the freedom struggle, that is the primary importance of the war for both soldiers and present historians, was the end of slavery. Historian Chandra Manning has argued that "slavery" stood at "the center of soldiers' views of the struggle." She claimed that "by the end of the war, white northern opinions about racial equality and civil rights, intractable though they had seemed in 1861, were far more malleable and vulnerable to intense self-scrutiny among Union troops than anyone could have imagined when the war began. ${ }^{19}$ Indeed, Manning and other scholars such as James Oakes, have done a superb job charting the ways in which some Union soldiers began to see the key meaning of the Civil War as the emancipation of enslaved African Americans.

While Manning and Oakes have written superb accounts that apply to some soldiers, they tend to overstate the breadth and depth of these views in the northern ranks. They have recognized the importance of slavery in soldiers' understandings of the war, but in transformative terms. Soldiers antebellum views and ideas changed over the course of the war; as troops came into contact with slavery, they imbued their cause with a humanitarian impulse to end slavery and incorporate formerly enslaved African Americans into the nation. But for many soldiers, the war confirmed, rather than transformed, earlier views.

\footnotetext{
${ }^{9}$ Chandra Manning, What This Cruel War Was Over: Soldiers, Slavery, and the Civil War (New York: Knopf, 2007), 11-12; and James Oakes, Freedom National: The Destruction of Slavery in the United States, 1861-1865 (New York: Norton, 2012).
} 
Indeed, historian Gary W. Gallagher has found that soldiers, throughout the war, saw the conflict as a struggle to save the Union. He has described how "they believed victory over the slaveholders confirmed the nation, made it stronger in the absence of slavery's pernicious influence, set the stage for the country's continuing growth and vitality, and kept a democratic beacon shining in a world dominated by aristocrats and monarchs." ${ }^{10}$ While northerners embraced the abolition of slavery, they often saw it one of many important aspects of the war. This dissertation looks more narrowly at Union soldiers and how they used the idea of the Slave Power thesis to sustain their commitment to the war.

Northerners, of different regions and different political affiliations, could draw upon the Slave Power thesis to inform their wartime Unionism. The Slave Power thesis worked well for them precisely because of its shadowy and vague conception of the threat that faced the Union. Its elasticity permitted soldiers from different regions to read their own antebellum cultural traits into the war; it allowed the persistence of localism to exist within a broad framework of Union and nationalism. Furthermore, the Slave Power thesis pried apart the institution of slavery from the enslaved themselves, which allowed many soldiers to oppose the institution of slavery without having to revise their prejudice about African Americans.

Encapsulated simply, the Slave Power thesis held that white southern elites, who accrued vast amounts of economic and political power through the enslavement of millions of African Americans, formed a domestic aristocracy that subverted republicanism in its continual quest for even more despotic power. This native oligarchy

\footnotetext{
${ }^{10}$ Gary W. Gallagher, The Union War (Cambridge: Harvard University Press, 2011), 6.
} 
deceived the common white men of the South and used northern Democrats, the so-called "Doughfaces," to capture the institutions of government. When northerners, primarily the Republican Party, attempted to limit the expansion of slavery, the Slave Power conspired to destroy the Union in an effort to preserve and consolidate their power. ${ }^{11}$

${ }^{11}$ Historians have written extensively about the idea of the Slave Power conspiracy. Chauncey S. Boucher, a historian at the University of Chicago, argued that southern politics had been divided before the war and the Slave Power conspiracy had been entirely a northern idea without much tie to reality. David Brion Davis saw the Slave Power conspiracy theory, following Richard Hofstadter, as an example of the "paranoid style" in American politics, somewhat confirming Boucher's views. More recently, Leonard L. Richards has shown that while the Slave Power conspiracy never approached a coherent movement, southerners and their northern allies had enjoyed disproportionate political clout during the antebellum years. Eric Foner and John Ashworth have both examined the idea of the Slave Power as a central tenet of Republican Party ideology. Both Larry Gara and Jeremy J. Tewell have noted that the Slave Power conspiracy theory allowed northerners to attack the institution of slavery while denying any humanitarian concern for enslaved African Americans. John Elliot Cairnes, Adelaide Weinberg, and Andre Fleche have charted the importance of the idea of the Slave Power conspiracy in mobilizing international support for the Union during the Civil War. Chauncey S. Boucher, "In Re That Aggressive Slaveocracy," Mississippi Valley Historical Review Vol. 8 No. 1/2 (June-September 1921), 14-15; David Brion Davis, The Slave Power Conspiracy and the Paranoid Style (Baton Rouge: Louisiana State University Press, 1969), 31; Richard Hofstadter, "The Paranoid Style in American Politics," in The Paranoid Style in American Politics and Other Essays (New York: Vintage Books, 1967), 4, 39; Leonard L. Richards, The Slave Power: The Free North and Southern Domination, 1780-1860 (Baton Rouge: Louisiana State University Press, 2000), 25; Eric Foner, Free Soil, Free Labor, Free Men: The Ideology of the Republican Party Before the Civil War (New York: Oxford University Press, 1970), 9, 316; John Ashworth, "Free Labor, Wage Labor, and Slave Power: Republicanism and the Republican Party in the 1850s," in The Market Revolution in America: Social, Political, and Religious Expressions, 1800-1880, edited by Melvyn Stokes and Stephen Conway (Charlottesville: University of Virginia Press, 1996), 142; Larry Gara, "Slavery and Slave Power: A Crucial 
Politicians of the wartime generation explained the war as the culmination of the Slave Power conspiracy. Foremost among these had been Henry Wilson, ${ }^{12}$ Historian Thomas J. Pressley has noted that Wilson "pictur[ed] a war which had grown out of the irrepressible conflict between slavery and freedom" and "he blamed it solely upon the conspiracy of Southern leaders; these men had succeeded in 'dragooning' the Southern states into secession... The cause of the war was thus the selfish ambition of evil men who were working always to advance the cause of slavery." ${ }^{13}$ Other northerners, including former general John A. Logan, wrote their own volumes following in the same

Distinction," Civil War History: A Journal of the Middle Period, Vol. XV, No. 1 (March 1969), 6; Jeremy J. Tewell, A Self-Evident Lie: Southern Slavery and the Threat to American Freedom (Kent, OH: Kent State University Press, 2013), 3, 87, 98-9; Cairnes, The Slave Power; Adelaide Weinberg, John Elliot Cairnes and the American Civil War: A Study in Anglo-American Relations (London: Kingswood Press, 1969), 6, 31; and Andre M. Fleche, The Revolution of 1861: The American Civil War in the Age of Nationalistic Conflict (Chapel Hill: University of North Carolina Press, 2012), 6, 131.

${ }^{12}$ Wilson completed the first two volumes of his history before dying. Samuel Hunt completed the third volume and prepared it for publication. Some debate exists regarding the authorship of the earlier two volumes; both Hunt and another friend of Wilson, Elias Nason, had been heavily involved with the first two volumes. See: John L. Myers, "The Writing of History of the Rise and Fall of the Slave Power in America," Civil War History Vol. 31 No. 2 (June 1985), 148-51; and Henry Wilson, Rise and Fall of the Slave Power in America.

${ }^{13}$ Thomas J. Pressly, Americans Interpret Their Civil War (Princeton: Princeton University Press, 1954), 39. 
vein. Enjoying wide distribution in the North, these books served to validate the antebellum and wartime political stands taken by their authors. ${ }^{14}$

Wilson and Logan had been wartime Republicans, but their writings displayed the hold that the concept of the Slave Power had upon the public mind more broadly both during the war and after. The Slave Power thesis had a wide circulation in the North. Whether or not it captured a reality in the South and whether or not it served as a purely partisan rhetorical device before the Civil War, most northerners would have been familiar with some incarnation of the idea. The Slave Power thesis gave northerners a powerful tool with which to explain the coming of secession, regardless of political affiliation.

A brief look at the editorials that appeared in a few Democratic newspapers during the secession crisis reveals how Republican claims of a Slave Power conspiracy crept across partisan lines and emerged in different regions of the country. Regardless of whether or not Democrats employed the language of the Slave Power conspiracy out of sincere belief or a desire to distance themselves from the idea that they had facilitated secession through their alliance with southern Democrats, editorials began to appear that adopted the Slave Power thesis's language and tone. Secession provided ample evidence that validated fears of a conspiracy; happily enough for Democrats, blaming a southern cabal also excused them from any knowing complicity in rending the Union asunder.

During the secession winter, northerners observed the ways in which the leaders of the southern states propelled their people toward the destruction of the republic. Pockets of overwhelming support for the Union in the east of Tennessee, the west of

\footnotetext{
${ }^{14}$ John A. Logan, The Great Conspiracy: Its Origin and History (New York: A. R. Hart, 1886).
} 
Virginia, and the east of Texas seemed to demonstrate that southern whites, on the whole, also objected to secession. Irregularities in the secession conventions of other states helped convince northerners that the southern political class had only presented the image of a popular referendum of secession, using the process to enrobe their conspiracy in the trappings of democracy. Further events, such as the seizure of Harpers Ferry by Virginia's ex-governor Henry A. Wise before the state had formally seceded, gave even more evidence that slaveholding politicians sought to drag their people into war. Amidst this climate, even Democratic newspapers began to draw upon the Slave Power conspiracy thesis to explain the crisis of the Union.

The Confederate decision to fire on Fort Sumter in Charleston harbor galvanized northern sentiment against the South. Papers that had formerly been friendly to Southern interests, such as the Columbus Daily Capital City Fact that had supported Vice President John C. Breckenridge in the presidential election, recommended that all supporters of republicanism rally around the flag. The editors declared that "civil war has been inaugurated by the act of the drunken minions of JEFF. DAVIS and his Slave Oligarchy." Blaming Jefferson Davis and his drunken minions limited responsibility for secession to that select, if inebriated, cabal. The editors also warned that "men who have disgraced their northern blood by sympathizing with the Southern oligarchy, had better change their tune, and that speedily." Here, the editors sought to distance themselves from charges that all northern Democrats had in effect been doughfaces. Beyond these admonishments, the editors thought that Confederate success would mean the subjugation of the North. They pointed out a dire threat to the common man, claiming that "Northern men, in the eyes of the Lords of the Lash and breeders of quadroon bondsmen, are no 
better than their chattle [sic] slaves." Because the oligarchy thus threatened the North, it had to be suppressed. The editors claimed that "where there is no Liberty, there can be no Democracy, and the great Democratic party which established and has maintained the Union of these States thus far, will be found as a unit rallying around the banner handed down to a generation who are taught to reverence JEFFERSON and worship WASHINGTON as the Father of his county." ${ }^{15}$

Other Democratic papers sounded similar notes in a way that showed how the Civil War itself would erode partisan identification. The Boston Herald, which claimed it had done the "utmost to accomplish" the election of Stephen Douglas, reminded its readers that "it is not a party question now, but a matter of self-preservation." The editors noted that once the war was over "we shall be the foremost to fight for the great Democratic doctrine of non-intervention." Yet the editors saw secession as something far different, and advocated a strong prosecution of the war because "the right of the people to self-government is too precious a boon to be overthrown by a revolution having for its object a reign of despotism and total disregard of the people." They claimed that the southern leaders aimed to establish "despotism more intolerable than any ever practiced in England, France, or Russia." The evidence for these allegations lay in the "refusal of the Southern Confederacy to submit their acts to the people in the seceded states." Thusly, the editors concluded that the "naturally over-bearing and despotic" slave owner had subverted the democratic process within the southern states themselves and sought to do the same to the republican experiment of the United States. The "arbitrary will" of the

\footnotetext{
15 "The War Commenced!," Columbus Daily Capital City Fact, April 13, 1861 in Howard Cecil Perkins, Northern Editorials on Secession, 2 vols. (New York: D. Appleton-Century Company, 1942), 728-29.
} 
slaveholder washed away the "blessings of civil and religious liberty." The editors of the Boston Herald showed how the Slave Power thesis could transcend partisan lines.

Secession could not be countenanced, even by the supporters of popular sovereignty and "nonintervention," because it was not popular at all. In fact, the southern oligarchs had taken great pains to prevent the people in the South from weighing in on the question of secession at all. ${ }^{16}$

While the editors of the Boston Herald had justified combating secession with "true" Democratic Party ideals, other editors called for a temporary end to partisan conflict due to the exigencies of the Civil War. The Pittsburgh Post, which had supported Stephen A. Douglas in the 1860 presidential election, exemplified this shift in rhetoric. The editors of the paper remarked: "The aspect of the question is now wholly changed from what it has hitherto been." Before Sumter, the question had been "a political one, and all conservative men, deprecating the horrors of a civil war, have earnestly urged a fair compromise granting the South her rights under the Constitution." The precipitate Confederate aggression had shifted matters from a political question to an existential crisis for the United States. The editors of the paper thought that "political partisanship must now cease to govern men on this issue." All northerners bore a responsibility for protecting the Union and "its property, its citizens, and its flag, and its granted rights against all usurpers, all rebels, all traitors." The Post saw secession as an attack upon all Americans. $^{17}$

\footnotetext{
16 "Fort Sumter Surrendered," Boston Herald, April 15, 1861 in Perkins, Northern Editorials on Secession, 730-31.

17 "The War Begun--The Duty of American Citizens," Pittsburgh Post, April 15, 1861 in Perkins, Northern Editorials on Secession, 738-39.
} 
Some newspaper editors expressed doubts that southerners had ever been sincere. The Rochester Daily Union and Advertiser remarked that "the Rebel leaders have 'precipitated a Revolution' simply by propagating a delusion, and making the masses of their people believe a lie." Here again reappeared the belief that secession conventions across the South had manipulated the electoral and democratic processes; the oligarchs had skillfully sidestepped a true democratic referendum on their actions, instead substituting lies and deceptions. The editors declared: "in no single instance we recall have the People been permitted to pass a free and unbiased judgment upon the Rebel programme; nor to indicate their own wishes in the premises." In light of secession, the editors evaluated the compromises that had maintained the Union until 1860 as acts of bad faith by the southern traitors; the compromises had just been plays for time as the oligarchs waited until they could enact their nefarious schemes in full. Northerners of all political stripes had not only a duty to protect the nation as a whole, but also to protect those whites in the South whose rights had been usurped by "the hands of a few rebel leaders who recognize no practical responsibility to the People, and who will yield to no influence but that of MIGHT." Despite what secessionists might claim, the editors avowed that "it is we--the States and People of the States yet remaining loyal to the Union and the Constitution--and not the Rebels, who are fighting for Liberty and the cause of Free Government." ${ }^{18}$

The editors of the Columbus Daily Capital City Fact tied together many of these strands of thought in an extended editorial that linked southern bad faith in antebellum

\footnotetext{
18 "Why We Must Fight and Why We Must 'Conquer the South'," Rochester Daily Union and Advertiser, May 2, 1861 in Perkins, Northern Editorials on Secession, 818-19.
} 
compromises to concealed aristocratic intentions. The paper grumbled that "for more than a half a century the North has voluntarily borne the self-imposed burden inseparable from an almost nationalized system of involuntary servitude, for the sole purpose of fostering and protecting Southern slavery and encouraging Southern taskmasters in the commission of licentious acts which have led to the present sad state of affairs." Due to northern acquiescence, the slaveholding elite had concentrated its power. ${ }^{19}$

Secession revealed that despite their talk of constitutional rights and liberties, Southern leaders sought to "humble the North at the shrine of their ideal Slave Oligarchy." With the war beginning, the paper warned that "deep-dyed, dark and damnable villainy, that once prowled in darkness and secrecy, now stalks the streets with the bold face of honesty" and "anarchy has clothed itself in Executive habiliments." Painting a grim picture of what awaited, the editors fulminated that "Treason is rampant, rebellion respectable, peculation honorable, assassination rewarded and murder legalized. All this, and more, that slavery may be perpetuated and freedom throttled."20

The editors spelled out a choice for readers: "we are destined to accept the law that coarse and sordid Oligarchy may vouchsafe, or fight again the battle for freedom." Declining to accept oligarchy, the editors sounded the tocsin, calling upon the North to "accept the sword, its unerring point directed at the heart of treason." Continuing, the editors invoked the American Revolution and the mission of the United States to serve as an example of republicanism in the world as a justification for crushing the aristocracy.

\footnotetext{
${ }^{19}$ The South--Past, Present and Future," Columbus Daily Capital City Fact, May 18, 1861 in Perkins, Northern Editorials on Secession, 837.

${ }^{20}$ Ibid, 837.
} 
They asked: "are we, the people of the only free government on God's footstool, who broke the sceptre of KING GEORGE and set our feet on the supremacy of the British Parliament, to surrender ourselves, bound hand and foot in the bonds of our own weaving, into the hands of this despicable and detestable Oligarchy?" The Democratic editors also warned that secession had awakened across the North "in fields, in farm houses, in workshops, and in tented camp...a spirit aroused which can never be silenced or exorcised till it has done its task." The start of the war meant that "the South is doomed, and with it slavery." The paper "bid the South beware of three calamities-Northern fanaticism, Southern slavery, and the vengeance of an outraged and insulted God." The editors opined that these forces, already unleashed, could not "be brought under the control of the Federal arm, and their aim is deep and terrible revenge." 21 While the Daily Capital City Fact warned that the Civil War doomed slavery, other papers called for its end. They advocated outright abolition as the best means with which to demolish the slaveholding aristocracy. The Madison, Wisconsin Daily Argus and Democrat drew a line from the nullification heresies of South Carolinian John Calhoun to the secession crisis and identified slavery as the mainspring behind both crises. The paper called for the North to end slavery. It claimed that although "no party at the north...sought or desired to weaken the Constitutional guarantees that protect slavery," secession had altered that state of affairs. The North had submitted to "measure after measure of rigorous and obnoxious legislation" to preserve the Union. The North had been honest the whole time, while the proslavery doctrines of Calhoun had been "nourished faithfully in secret" and spread by "the arts of demagogues, the labors of men

${ }^{21}$ Ibid, 838-39. 
high in power, and constant efforts to excite the Southern mind." Taking all of this into consideration, the editors called for "the total extinction of slavery" as the only way to resolve the problem. ${ }^{22}$

These examples from newspapers during the secession crisis and the first days of the war serve not to argue that Democrats wholeheartedly endorsed the Slave Power thesis, but to illustrate that as war erupted, northerners of all political stripes could draw upon the Slave Power thesis as a means to argue for a war with the South, and that it held deep cultural currency across the North. The papers quoted here show that northerners from the northeast, the mid-Atlantic, and the West could all invoke the Slave Power conspiracy thesis. The idea that a Southern oligarchy had "dragooned" its own white population to support its aristocratic heresies and pretentions gained traction. The oligarchy had to be confronted, because its newfound "bold faced honesty" demonstrated the futility of compromise. Not only did the slaveholding elite threaten the American experiment as a whole; secession also portended an attempt to enslave white northerners. What mattered about the claims of Democratic editors was not the validity of their claims so much as that they could couch their explanations for the coming of the war in terms of the Slave Power thesis. Their calls for northern action, likewise, rested upon the assumptions of the Slave Power conspiracy. Even before the war began in earnest, northerners had begun to turn to the Slave Power thesis as a way to explain the coming cataclysm. This explanation transcended partisan political lines and provided the northern

\footnotetext{
22 "The Abolition of Slavery the Only End of This War," Madison (Wisconsin) Daily Argus and Democrat, May 4, 1861 in Perkins, Northern Editorials on Secession, 822-24.
} 
populace with a plan of action. The war would need to chasten the slaveholding oligarchy, if not sweep it away entirely.

Five salient points emerge from this discussion of the Slave Power thesis. First, by the start of the Civil War, the Slave Power thesis had circulated widely in the North. Before the war, the thesis had been a part of the Republican Party's message about why slavery's expansion had to be stopped. The expansion of slavery further aggrandized the southern oligarchy, thereby threatening liberty and the free labor system of the North. If the thesis was couched in strictly partisan terms during the 1850 s, secession seemed to prove it correct. While Democratic editors might disagree with the Republican Party as a whole, secession demonstrated that an aristocratic minority had captured power in the South. Democratic editors also had a powerful incentive to promulgate this view, as it shifted emphasis away from the complicity of northern doughface Democrats in the political turmoil of the 1850 s. Allowing the South to form its own nation would not only subject the white men of the South to the tyranny of the aristocracy, but it also threatened the very principles of American republicanism that formed the bedrock of liberty for all white Americans.

Second, the Slave Power thesis meshed well with the idea that nineteenth century Americans served as the sole beacon of republicanism in the world. The struggle of the North against the South represented the conflict between those who believed in the providential mission of America in the world to spread the light of liberty and domestic traitors who sought to enshrine a revanchist regime that would reverse the American Revolution and restore despotism in the New World. Within the international context of the revolutions of 1848 and resurgent monarchies in the Old World, aristocracy appeared 
robust. The Slave Power thesis explained the Civil War in terms that rendered moot many political differences in the North. While the Democratic Party fought the Republican Party tooth and nail over the best way to preserve the Union, neither party advocated for a Slave Power. Both parties could use the thesis to explain precisely how the Confederacy threatened the Union, and by extension, republicanism in the world.

Third, the Slave Power thesis gave northerners a clear enemy, the southern gentry. This allowed them to avoid many thorny questions that would arise in the war, most acutely the place of African Americans in the nation. The Civil War had come about as a result of the white oligarchy's attempted subversion of the republican ideals that undergirded equality for white men. As the editors of the Daily Capital City Fact and the Daily Argus and Democrat had recognized, the institution of slavery stood at the heart of the conflict between the North and the South. Many northerners knew that the Civil War was "about" slavery, but they understood this to mean the institution rather than the enslaved themselves. Attacking the system of slavery would undermine the aristocracy, and therefore could be a palatable means of prosecuting the war. Yet, justifying attacks on the system of slavery in this fashion also left aside consideration of the enslaved African Americans themselves. Belief in the Slave Power conspiracy allowed some northerners to accept that emancipation would come because it would wipe out the southern slaveholding cabal that had caused the war, but it offered little prescription for how the millions of enslaved black people in the South should be treated or what their place in the nation would be.

Fourth, the Slave Power thesis gave northerners a way to explain the differences between the North and South. Any perceived inferiority in the South, from differences in 
speech to farming practices, could be explained within the context of a southern aristocracy that had conspired to degrade other southern whites. Conveniently for northerners, the Slave Power thesis naturalized their northern culture and modes of labor. The Southern oligarchs had perverted the lands under their dominion and diverted them from the course they should have followed. Therefore, northerners could fight to restore what should have been while avoiding any deep contemplation of northern complicity with the Slave Power or the ways in which northern economic development had contributed to sectional tension. Crucially, the thesis allowed many northerners to define the Civil War as a fight against the slaveholding cabal rather than as a struggle for any precisely defined idea of Union. The Slave Power thesis could embrace a multitude of local interpretations because it united northerners by defining what they were fighting against rather than clearly stating any controversial idea of what they fought for.

Fifth, as the Democratic editorials suggest, the Slave Power Conspiracy thesis transcended partisan political lines. Partisan politics during the antebellum period had presented competing visions for the American Union. The Slave Power Conspiracy thesis allowed soldiers to see the war as something above partisan politics; through secession, it threatened the entirety of the American system. Arguing about political planks during the war seemed, for many soldiers, as a distraction from the real effort of the war. This led to the emergence of a wartime Unionism that temporarily set aside partisan differences, as historian Adam I. P. Smith has documented in his work. ${ }^{23}$

\footnotetext{
${ }^{23}$ Reid Mitchell also noted that after the outbreak of the war, "no longer would party dominate men's loyalties and demand all their affections...The war would destroy the old, temporizing, divisive ways of the past forty years of politics." Reid Mitchell, Civil War Soldiers, 18; Adam I. P. Smith, No Party Now: Politics in the Civil War North (New York: Oxford University Press, 2006); and, Adam I. P. Smith,
} 
Thus, as northern men rallied around the flag and marched to war, they did so in an environment where the Slave Power conspiracy thesis had permeated their culture. As they ventured further and further into the South, they found strong evidence that confirmed their suspicions of the depraved and tyrannical nature of the slaveholding oligarchy. They found whites whom they perceived as being corrupted under decades of domination. Here northerners saw powerful evidence of what awaited them if they failed to depose the southern aristocracy. Whereas the expansion of slavery had previously been an abstract fear, poor white trash groveling outside of hovels and rooting in the dirt, looking scarcely less bestial than the hogs they ate, revealed what domestic aristocracy designed to inflict upon the North. The Slave Power thesis gave soldiers a framework within which they could cast their war as a cause of global-historical importance--the last chance to save republicanism in a world increasingly hostile to the idea--while imbuing it with the idea that immediate danger awaited if the oligarchs gained the opportunity to form their own nation and then inflict their despotism upon the North.

Such an appeal served as an ideology that sustained Union soldiers during the war, and one that placed an emphasis on the preservation of the Union as a means to smother domestic tyranny. This ideology could advocate an immediate end to the system of slavery, as it served as the heart of power for the southern elite. Soldiers understood that the most efficacious way to strike at the power of the slaveholder lay in taking away his slaves. Not incidentally, such a view also left aside consideration of what would

\footnotetext{
"Conservatism, Transformation, and the War for the Union," in Reconfiguring the Union: Civil War Transformations, edited by Iwan W. Morgan and Philip John Davies (New York: Palgrave Macmillan, 2013).
} 
happen to the enslaved people after they had been freed. For some northerners, the Slave Power held immense appeal precisely because it provided a meaning for the Civil War while leaving aside a precise positive definition for Union or liberty. It also allowed soldiers to see themselves as important actors on the right side of world history, no matter how small their individual contributions to the cause. For these reasons, the Slave Power thesis could motivate soldiers from different regions and allow local innovation during the war years. In addition, the global-historical importance of the struggle, as defined by the victory of republicanism over aristocracy, persisted far into the postwar period.

The five chapters of this dissertation chart some of the wartime expressions of the Slave Power Conspiracy thesis among soldiers from different regions. The first three chapters examine how antebellum cultural contexts shaped how soldiers saw the war, and how the Slave Power Conspiracy thesis could accommodate these views. The final two chapters show how soldiers continued to use the idea far into the postwar period. Unlike Reid Mitchell and Randall Jimmerson, I chart the ways in which soldiers could draw upon the Slave Power Conspiracy thesis both during the war and after.

The first three chapters draw upon wartime testimony from Union soldiers. This testimony takes the form of letters, both to friends and families as well as hometown newspapers, and diaries kept at the time. As historian Chandra Manning has noted, "Civil War soldiers' letters and diaries offer unparalleled insight into the thoughts of ordinary Americans during a defining time in the nation's history. ${ }^{24}$ While soldiers undoubtedly changed the content of their letters or diaries based on who they expected to read them, these sources provide the best way of examining what they thought about the Civil War. I

\footnotetext{
${ }^{24}$ Manning, What This Cruel War Was Over, 9.
} 
have relied nearly entirely upon contemporary letters and diaries, written at the time of the events they describe or shortly thereafter. In a few instances, I have turned to postwar memoirs, but usually only when contemporary sources mention the same events. In my handling of this evidence, I differ little in general approach from historians such as Jimmerson, Manning, Mitchell, and McPherson.

In one key respect, I handle these sources quite differently from Jimmerson, Manning, Mitchell, and McPherson, however. All of these scholars took a broad approach, essentially treating soldiers, North and South, as somewhat interchangeable within their respective sides. Instead, I have looked at how the Slave Power Conspiracy thesis allowed for a considerable expression of idiosyncratic regional culture. I see regional antebellum culture as an influence that broadly connected soldiers from similar areas in ways that often proved more pronounced than other lenses such as partisan affiliation or class identity. For instance, an officer from Keokuk, Iowa would share more in his view of the Civil War with an enlisted man from Terra Haute, Indiana, than an officer from Philadelphia, Pennsylvania. When soldiers' letters and diaries are read in terms of regional origin rather than in terms of partisan identification or class, trends emerge that would otherwise remain submerged. A reading of testimony in this fashion helps show how soldiers could draw upon the implicit tenets of the Slave Power conspiracy thesis during the war while maintaining a parochial outlook.

Chapter One looks at troops from Pennsylvania and New Jersey. These soldiers saw the Civil War through the lens of the American Revolution, as they were steeped in its history and came from areas rich in battlefields from that earlier war. They saw themselves as fighting to preserve the gains of the Revolution, which had been perverted 
by the Slave Power. They solidified their commitment to the Union through visits to sites in the South associated with the Revolution and the founding generation, which also reinforced their sense that they fought against a domestic aristocracy. Their battlefield tourism also shaded into commemoration of their own battles, thereby intertwining even more firmly their war with the Revolution. The Slave Power Conspiracy thesis helped in the process, as it affirmed that republican democracy had been subverted by a domestic aristocracy, and thus the Civil War was a reenactment of the American Revolution. Gallant patriots from Pennsylvania and New Jersey, like their forebears in the Continental Army, nobly fought against despotism.

Chapter Two looks at western troops from the states of Indiana, Illinois, Iowa, Michigan, and Wisconsin and examines how their particular western ideas of masculinity influenced their use of the Slave Power Conspiracy thesis. Many soldiers from these areas shared an idea of a robustly independent masculinity shaped by their frontier residence and staunch belief in free labor. They believed that a man wrested profit from the soil as a farmer, and set aside personal considerations when duty called. Within this context, they saw their service as the true measure of masculinity. These soldiers zealously defended their independence and saw in secession a conspiracy to enslave them and rob them of the fruits of their labor. Beyond seeing the southern oligarchy as the enemy, they also tended to see eastern soldiers as similarly inclined to place personal profit and advancement ahead of patriotism, leading to tension with eastern troops. Westerners also expressed their patriotism through white-supremacist free-labor ideals tied to their concept of masculinity. In the South, they came into contact with what they often dubbed "poor white trash," and saw in these southerners what the Slave Power, 
abetted by pusillanimous northern Democrats, held in store for them. This helped move them to embrace emancipation as a war measure, as the best way to depose the Slave Power was to take away the slaves that gave it strength. Yet contact with large numbers of enslaved African Americans in the South horrified many of these soldiers because it demonstrated to them what the Slave Power held in store for them, and so while they supported emancipation, they found little reason to set aside their antebellum prejudices. For some westerners, the Slave Power thesis gave them a framework with which to interpret what they saw in the South and gave them a clear goal in the war.

Chapter Three considers troops from the urban northeast who used the antebellum popular entertainment of the blackface minstrel show as a strategy to contain the radical nature of emancipation and the potential for racial egalitarianism. Many soldiers from the urban northeast used the Slave Power conspiracy thesis to explain the breakdown between the sections and the coming of secession. They felt deeply that they needed to maintain the Union, particularly because the Confederacy represented resurgent aristocracy. These soldiers carried to the field their tradition of the blackface minstrel show, a form of entertainment that had developed in primarily working-class theaters during the antebellum era as a way for urban workers to reassure themselves that they still maintained the independence necessary for participation in a republican democracy. This tradition meshed well with the Slave Power thesis, as urban northeastern soldiers felt little sympathy for the enslaved African Americans they encountered and the Slave Power thesis allowed them to leave aside questions of race. They saw little contradiction between hating slavery and abusing blacks. As Union war aims shifted, incorporating 
emancipation as a key war goal, the blackface minstrel show helped these soldiers to reassure themselves that they remained superior to African Americans.

The final two chapters, concerned with charting how soldiers utilized the Slave Power Conspiracy thesis after the Civil War, necessarily rely upon different kinds of testimony. When the war ended, soldiers returned home, and thus had little reason to carry on a voluminous correspondence. Yet they did not remain silent regarding the Civil War and the role they had played in it; in addition to well-known commemorative activities, such as establishing graveyards, participating in patriotic parades, and erecting monuments, they kept up a lively literary output about the war. The final two chapters look at some of these public forms of communication and how the Slave Power Conspiracy thesis emerged in them as a way to interpret the Civil War, using sources seldom mined by historians.

Chapter Four delves into regimental histories written in the immediate postwar years of 1865 and 1866. These regimental histories, produced locally for parochial audiences, reaffirmed the Slave Power thesis. Historians have underutilized regimental histories, believing them to be works that presented exaggerated accounts of the exploits of individual regiments, bereft of truthful or meaningful content. Soldiers, however, used regimental histories not only to describe their experiences for audiences at home, but also to tell their communities what the war had been about. Overwhelmingly, these nearly 50 regimental histories written in the years directly following the Civil War portrayed the conflict as a struggle of the North against an aristocratic South. Authors portrayed the South as a backward land and blamed this economic underdevelopment on a system of slave labor that had prevented true democracy. Behind this baleful system stood a white, 
slaveholding oligarchy that had sparked the war in an effort to accrue even more power and despotic dominion. Authors saw most white southerners and former Confederates as dupes of the oligarchy. In their eyes, support for the Confederacy had been a virtuous patriotism that the oligarchy had perverted through sustained pressure. White southerners, on the whole, appeared as a people who had been deluded by their leaders rather than as sincere supporters. Because the authors of regimental histories tended to see the war as a battle against the homegrown aristocracy, they often accorded little sustained consideration to African Americans. In regimental histories, soldiers began to shift from an implicit acknowledgment of the Slave Power conspiracy to an explicit one, as they consciously reflected on the meaning of the war at greater length.

Chapter Five demonstrates that soldiers remained remarkably consistent in identifying a slaveholding aristocracy as the culprits behind the Civil War. It does so through the examination of the published speeches of the Military Order of the Loyal Legion of the United States (MOLLUS). The MOLLUS patterned its organization on the Society of the Cincinnati, a group which had been formed by officers of the Continental Army in order to preserve the gains of republicanism after the American Revolution. They aimed to preserve for posterity what they saw as the facts of the war effort. Toward this end, members delivered speeches at meetings and public gatherings; later they published their speeches and disseminated them as pamphlets or bound volumes. The bulk of their papers appeared in the last two decades of the nineteenth century and the first of the twentieth. In this sense, they represented a northern effort to ensure that their interpretation of the war got into the books. In sum, the papers reflected a northern rejoinder to the Southern Historical Society Papers, a southern publication effort that 
sought to valorize the Confederate cause and Robert E. Lee's Army of Northern Virginia, in particular. For the veterans of MOLLUS, the Slave Power Conspiracy theory allowed them to aggrandize their own accomplishments by placing their victory within a globalhistorical context of the victory of republicanism over aristocracy redolent of the American Revolution. Much as it had functioned in wartime, the turn to the Slave Power Conspiracy theory also enabled these veterans to sidestep thorny questions regarding the place of formerly enslaved African Americans in the nation, as the narrative of the war that emerged placed emphasis upon virtuous white northerners shattering a slaveholding elite.

Taken together, these chapters show the importance of the Slave Power Conspiracy thesis to soldiers who fought in the Civil War. Broadly speaking, the Slave Power Conspiracy thesis allowed soldiers to link their parochial cultures with the national struggle, primarily because it defined the war as a struggle against a domestic aristocracy and thereby placed enslaved African Americans on the margins of the conflict. After the war, the Slave Power Conspiracy thesis provided soldiers a framework within which they could valorize their own conduct; they had won a second American Revolution by overthrowing the slaveholding oligarchy. Anything that occurred in the postwar period with the formerly enslaved African Americans had little, if any, connection in their minds to the stature of their wartime efforts. Indeed, discussion of the Slave Power Conspiracy became even more pronounced and direct in the late postwar period, when elderly veterans in the MOLLUS sought to establish what they saw as the global-historical importance of the Civil War, which had swept away the last vestiges of aristocracy in 
America. The United States, unhindered by these vestiges of the past, could assume its proper role as a unified and unsullied beacon of republicanism in the world.

Historians have therefore undervalued the importance of the Slave Power Conspiracy thesis in sustaining the commitment of northern soldiers to the Union. The idea gave them a clear enemy to oppose--the slaveholding oligarchy--while accommodating local cultural variations. The Slave Power Conspiracy also allowed some soldiers to separate their struggle from questions regarding the enslaved themselves, leaving consideration of those issues until after the war. The Slave Power thesis also allowed some soldiers to support emancipation and the enlistment of African Americans without necessarily endorsing civil rights for African Americans or their full integration into the American nation; the Slave Power posed such an existential threat that previously unthinkable actions could be contemplated. The force of the Slave Power Conspiracy thesis can also been seen in how soldiers returned to the idea in their descriptions of the Civil War, even into the twentieth century. It helped them to place their war within a global-historical framework that gave their struggles transcendent importance, the equal of the Revolutionary generation. 


\section{Chapter 1 \\ "For the Union, Constitution, and Enforcement of the Laws": Pennsylvania and New Jersey Troops Confront the Slave Power \\ $* * * * * * * * * * * * * * * * * * * *$}

After Sunday morning inspection, Private Milton McJunkin of the 85th

Pennsylvania Infantry Regiment took a walk around camp, and came across the grave of a fellow soldier from Pennsylvania. In a reflective mood, he sat down to write a letter home to his friend Thomas West, laying out the reasons why he found the struggles of the three long hard years of warfare worthwhile. He wrote of "the invaluable services, the great hardship and suffering's of the common soldiers, the million or more of brave, patriotic men, who sacrificed the comforts of home, the proffits of business, the tenderest ties of affection, to uphold the old flag, and to conquer the enemies of a free, liberal, constitution government." 25 The Union had called, and patriots answered. McJunkin described for his friend the travails he and others had gone through, how soldiers all underwent "severe trials, hardships, exposure and suffering to which they are inevitably allied, foot sore, overwearied, overburdened, and often (but necessarily) ill fed, under torrid heat, and freezeing cold."

Beyond the elements, soldiers confronted "the field of carnage, when the grass was yet wet with blood" and the "saddest of all sounds, the wounded soldiers last sigh." The sight of "dead soldiers, scattered over meadows, grainfields, orchards or in trenches and parallel's, festering in the sun, or stark and frozen by the winter's frost, with torn and clotted garments, always come back to us when we reflect upon the shocking, terrible realities of the present war, and how many hearts are saddened, how many homes are

\footnotetext{
${ }^{25}$ I have left internal grammar consistent with the original sources without the use of "sic." Any interventions have been made with brackets.
} 
desolated by the loss of the returning brave." He thought that the nation owed "an immense debt of gratitude to the rank and file of our armies. they have borne the burthens of the war. they have fought our battles, won our victories and rolled back the accursed waves of rebellion...let us not forget those brave men." He concluded, emphatically, that "they have fought the great battles of constitutional freedom between a slave oligarchy and a republican government. ${ }^{26}$ The grave of his fellow Pennsylvanian had called forth McJunkin's own statement on why he found value in serving his country. Three months later, he himself would lie beneath Virginia sod after falling ill at Bermuda Hundred and dying in the hospital at Portsmouth.

As McJunkin's letter hinted, some soldiers from the mid-Atlantic states of Pennsylvania and New Jersey could see the Civil War as a battle between "constitutional freedom" and "a slave oligarchy." They thought that they fought against a Slave Power, but they interpreted that concept through the lens of the American Revolution. Some of these men emphasized that they fought to preserve the Constitution and the laws, thereby preserving the Union. Their heritage from two states deeply associated with the American Revolution led them to see the Civil War as a struggle to confront the Confederacy's usurpation of the rightful laws that ensured the perpetuation of the American republic. As they considered the historic landscapes of northern Virginia that they traversed on campaign and the heroes it had given birth to, they also considered the natural landscape. They found in it a vast potential; it had already sired statesmen of the highest caliber and

\footnotetext{
${ }^{26}$ Milton McJunkin to Thomas West, January 17, 1864 in The Bloody 85th: The Letters of Milton McJunkin, a Western Pennsylvania Soldier in the Civil War, compiled and edited by Ronn Palm, Richard Sauers, and Patrick A. Schroeder (Lynchburg, VA: Schroeder Publications, 2002), 109-10.
} 
could do so again. Accordingly, some Pennsylvania and New Jersey troops looked more charitably on the landscape of the South. Instead of seeing a landscape degraded by slavery, they saw fertile fields and a land that simply needed the return of lawful order to make it productive again. Within these contexts, the institution of slavery looked less threatening to these soldiers. Accordingly, they proved rather open to the integration of African American labor within the army and to emancipation.

Some troops from Pennsylvania and New Jersey saw the war as a struggle between legally constituted authority and a scheming Slave Power. Many troops from the Mid-Atlantic tended to interpret their goal as the maintenance of the Union and Constitution against the lawlessness that the slaveocracy threatened. While scholars have argued that troops from the Mid-Atlantic envisioned moderate war aims, they have often neglected how these views fit within the framework of the Slave Power conspiracy thesis. ${ }^{27}$ Private Alonzo B. Searing of the 11th New Jersey Infantry Regiment wrote a

${ }^{27}$ Scholars who have looked at what motivated Pennsylvania troops to enlist have found a variety of factors, but all stress the relative moderate war aims that these soldiers envisioned. They also stress that enlistment patterns, and sentiments in uniform, do not conform readily to antebellum or wartime partisan politics. Historian Carol Reardon argued that in Centre County, Pennsylvania, many who enlisted held politically moderate aims. In her study of the 148th Pennsylvania Infantry Regiment, she discovered that on the whole, volunteers exhibited "moderate civic values" that "extended to the population at large." While a study of a single regiment, Reardon's article suggests that moderation among Pennsylvania troops reflected views held by a broader swath of the population. Likewise, historian Mark A. Snell has found that soldiers from Pennsylvania's York County, at least initially, enlisted due to rage militaire and that both Republican and Democratic newspapers supported the war effort in the months following the Confederate attack on Fort Sumter. More recently, Kathleen Shaw detected little evidence that partisan political sentiments had a major effect on enlistment rates of young Pennsylvanians in Franklin County. Timothy J. Orr has also 
brief poem that he sent home to his sister, which concluded "We have joined the Union Army,/ To fight for a holy cause--/ For the Union, constitution/ And enforcement of the laws." ${ }^{28}$ Private George Washington Beidelman of the 71st Pennsylvania Infantry Regiment told his father "One part of the nation [is] in rebellion and against the laws and properly constituted authorities of the government... and refusing to submit to its functions, without a single reason.... and infested with a band of treason plotters, whose

written that antebellum partisan affiliations fell aside over the course of the war as soldiers came to advocate continuation of the war. William J. Jackson, writing of the motivations that led New Jersey troops to enlist, also found a broad desire to confront traitors rather than partisan political motivations. Carol Reardon, "'We Are All in This War': The 148th Pennsylvania and Home Front Dissension in Centre County During the Civil War," in Union Soldiers and the Northern Home Front: Wartime Experiences, Postwar Adjustments, edited by Paul A. Cimbala and Randall M. Miller (New York: Fordham University Press, 2002), 5; Mark A. Snell, "'If They Would Know What I Know It Would Be Pretty Hard to Raise One Company in York': Recruiting, the Draft, and Society's Response in York County, Pennsylvania, 18611865," in Cimbala and Miller, Union Soldiers and the Northern Home Front, 78-85; Kathleen Shaw, "'Johnny Has Gone for a Soldier': Youth Enlistment in a Northern County," Pennsylvania Magazine of History and Biography Vol. 135 No. 4 (October 2011), 428-29; Timothy J. Orr, "'A Viler Enemy in Our Rear': Pennsylvania Soldiers Confront the North's Antiwar Movement," in The View from the Ground: Experiences of Civil War Soldiers, edited by Aaron Sheehan-Dean (Lexington: University Press of Kentucky, 2007),171-98; and William J. Jackson, New Jerseyans in the Civil War: For Union and Liberty (New Brunswick, NJ: Rutgers University Press, 2000), 37-58.

${ }^{28}$ Alonzo B. Searing to Sister, October 3, 1862 in Alonzo's War: Letters from a Young Civil War Soldier, edited by Mary Searing O'Shaughnessy (Madison, NJ: Fairleigh Dickinson University Press, 2012), 14. 
sole aim is to attain the object of their unrighteous ambitions, by the overthrow of the best Constitution and government the world has ever produced." 29

Fear of the subversive lawlessness of the Slave Power overrode partisan politics among some soldiers from New Jersey and Pennsylvania; Southern intransigence and the need to protect the Constitution erased fewer monumental partisan squabbles. Private Benjamin Parks the 6th Pennsylvanian Reserves (35th Pennsylvania) Infantry Regiment explained to his friend Henry Eyer why he had enlisted. He pointed out that "the Oligarchy which has sprung up in our midst strong and determined in purpose, aims at the very vitals of our Republic, which has by its nurturing institutions brought it from utter insignificancy to comparitive greatness, it has peirced the very bosom which nourished it--defied our law and dared raise a rebel standard." Parks saw the war as a stark choice between "government...preserved, our flourishing institutions[,] which like the stars of heaven shine with an unchanged and eternal luster in all climes" or "a potentate with robes of majesty," before whom Americans would "bow beneath the sway of a Sceptre." He thought that the duty of all "freedom loving people" lay in combating the enemy, who prepared "perfidious designs and intrigues to dash down as with Herculanium our greatness, as a nation, and hurl all wrecked mass in the Oceon of oblivion leaving not vestage of our former grandeur and potency." Parks closed by

\footnotetext{
${ }^{29}$ George Washington Beidelman to Father, May 15, 1861 in Catherine H. Vanderslice, The Civil War Letters of George Washington Beidelman (New York: Vantage Press, 1978), 14.
} 
remarking "It matters little wether we are Republicans or Democrats, so we are honest, loyal, and true." 30

These same troops also pointed to a slave-holding oligarchy as the architects of disunion. Parks aligned the South with the trappings of monarchy: "a potentate with robes of majesty" and "a Sceptre." Captain Levi Bird Duff of the 105th Pennsylvania Infantry Regiment thought that "under our laws through the influence which slave-holders have exercised on congress, slavery has for the last half century been a sacred institution. Shall it be sacred still when it imperils the very existence of our government... Whenever the causes which produced this rebellion are thoroughly understood by the men in power \& they have the courage enough to act according to their convictions we may expect it to be crushed, not sooner." ${ }^{31}$ He later elaborated that in the South people "were descendants of the aristocratic families of the old world \& have always lived under the influence of the institution of slavery never knew nor practiced democracy as understood by us at the North. It is not surprising that they rebelled." ${ }^{32}$ Captain Edward A. Acton of the 5th New Jersey Infantry Regiment believed that "Ambitious men who desire power and fame have

\footnotetext{
${ }^{30}$ Benjamin Theodore Parks to Henry C. Eyer, September 4, 1861 in "Civil War Letters Concerning Members of Co. G, 174th Reg. P.V.I.," edited by William A. Russ, Jr., Susquehanna University Studies Vol. 5 No. 3 (April-June 1955), 183-85.

${ }^{31}$ Levi Bird Duff to [Wife], September 25, 1861 in To Petersburg with the Army of the Potomac: The Civil War Letters of Levi Bird Duff, 105th Pennsylvania Volunteers, edited by Jonathan Helmreich (Jefferson, NC: McFarland \& Company, 2009), 20.

${ }^{32}$ Levi Bird Duff to [Wife], February 1, 1862 in Helmreich, To Petersburg with the Army of the Potomac, 36-37.
} 
staked every thing upon the success of this rebellion and their own personal interest...They will be ranked with Judas Iscarriot \& Benidict Arnold." ${ }^{33}$

Alonzo Searing, near the end of the Civil War, reflected upon the Confederacy. He opined that "the poor dupes who fought its battles will now have to return to their homes" with "the mortifying thought that they have been exerting their utmost energies to subvert the best Government that ever existed." Here, a crucial aspect of the Slave Power thesis emerged. The slaveholding oligarchy, while a baleful presence on the national stage, had also subverted republicanism at home. The common Confederate soldier had been a "poor dupe" of the white elite; his energies had been bent towards defending the prerogatives of the slaveholders. In Searing's opinion, the northern soldier had fought sincerely and with a clear vision of "preserving our glorious Union intact as it was bequeathed to us by our forefathers." ${ }^{34}$

In these ways, some troops from Pennsylvania and New Jersey believed that a slave-holding oligarchy had subverted republicanism in the United States. Parks, for instance, identified an oligarchy that sought to consign America to a historical footnote, a curiosity such as the Roman town of Herculaneum, which had been buried under a layer of ash by the eruption of Mount Vesuvius, along with the better-known city of Pompeii. Levi Duff, likewise, saw that slaveholders had mobilized their resources within the Federal government in order to protect their prerogatives, and drunk with their power, thrust the nation into turmoil. But, these soldiers also drew parallels in their accounts

\footnotetext{
${ }^{33}$ Edward A. Acton to Mary, April 18, 1862 in Mary Acton Hammond, "'Dear Mollie': Letters of Captain Edward A. Acton to His Wife, 1862," Pennsylvania Magazine of History and Biography Vol. 89 No. 1 (January 1965), 11.

${ }^{34}$ Alonzo B. Searing to Sister, April 23, 1865 in O'Shaughnessy, Alonzo's War, 214.
} 
between the slaveholding aristocracy and the British aristocracy of an earlier generation. Parks, for instance, aligned the Confederacy with the traditional hallmarks of tyranny. Duff, for his part, aligned the United States with Jesus Christ; the United States stood as the savior of the world, shining the beacon of republicanism into the aristocratic darkness. The Confederate "traitors" played the role of Judas Iscariot, who had sold out the Messiah for filthy lucre. Crucially, Duff also invoked the Revolution, placing the betrayal of republicanism by Benedict Arnold in the earlier war as an act equal in cravenness to that of Judas.

Thus did troops from Pennsylvania and New Jersey cast themselves as the successors of the generation of the American Revolution. ${ }^{35}$ Like their forebears, they girded for war against an aristocracy, this time one of slaveholders. Levi Bird Duff proclaimed: "I feel proud of my position humble though it be. I would rather be a soldier in this great American army than be a king. I am as proud of my country as the old

\footnotetext{
${ }^{35}$ The Revolution and the heroes of the early Republic held great sway in Pennsylvania, particularly Philadelphia. J. Matthew Gallman has investigated how civil rituals that celebrated Washington and the founders were adapted to supporting the Union cause in the Civil War. Albrecht Koschnik has charted the peculiar sway the Federalist Party had on partisan politics in Philadelphia until the 1840s. Sean Nalty has shown the growth of antiparty nationalism with the Union Party in Pennsylvania during the Civil War. J. Matthew Gallman, Mastering Wartime: A Social History of Philadelphia During the Civil War (New York: Cambridge University Press, 1990), 85-116; Albrecht Koschnik, "Let a Common Interest Bind Us Together": Associations, Partisanship, and Political Culture in Philadelphia, 1775-1840 (Charlottesville: University of Virginia Press, 2007); and Sean Nalty, "'Come Weal, Come Woe, I Am with the Anti-Slavery Party': Federalism and the Formation of the Pennsylvania Union Party," in A Political Nation: New Directions in Mid-Nineteenth-Century American Political History, edited by Gary W. Gallagher and Rachel A. Shelden (Charlottesville: University of Virginia Press, 2012), 143-66.
} 
Roman was of his. The day of calamity is upon her; I rejoice that I am permitted to aid in her defense." He continued, "I have often envied the men of '76. And I have sometimes thought that in my day there would be nothing to $\underline{\text { do. }}$. Little did I think that so soon so great a responsibility was to fall upon the shoulders of the young men of this country." ${ }^{36}$ As he described to his wife the pride he took in service, Duff explicitly connected his war to the Revolution. For Duff, the volunteers of 1861 were as heroic within the American pantheon as the Minute Men of 1776.

Duff's attitude was hardly unique. Troops from Pennsylvania and New Jersey, more so than their counterparts in the West, viewed the Civil War as a second chapter in the Revolution. They fought to uphold the laws and Constitution, as well as the Union the founding documents created. Troops from the mid-Atlantic did not just venerate the country's founding in the abstract. Raised in an area dotted with locations significant to the Revolution, they found concrete personal links to that earlier conflict. Throughout their campaigns in Virginia, troops from Pennsylvania and New Jersey flocked to sites associated with George Washington and the Revolution, seeking physical souvenirs to remind them of the ties between the past struggles and their own. Their Revolutionary War battlefield tourism became linked to their own struggles, as their battles merged with those of the past, most particularly at Yorktown. Some soldiers even began to revisit their own battlefields in the manner that they had previously reserved for the Revolutionary War sites. These constantly fashioned and refashioned connections to Washington and the Revolution rooted their abstract idea of fighting to preserve the laws and

\footnotetext{
${ }^{36}$ Levi Bird Duff to [Wife], September 27, 1861 in Helmreich, To Petersburg with the Army of the Potomac, 21.
} 
Constitution--under assault from the corrupt slaveholding oligarchy--in the physical world. Some soldiers, through their visits to earlier hallowed grounds, saw themselves as reenacting the struggle of the Revolutionary generation against a hostile aristocracy.

Troops from Pennsylvania and New Jersey had grown to maturity aware of the direct connections to the Revolution all around them. Valley Forge, in Pennsylvania, had become almost synonymous with George Washington and the travails of his Continental Army. ${ }^{37}$ Some of Washington's most important battles had occurred in the mid-Atlantic, including his famed crossing of the Delaware River and the battles of Trenton, Brandywine, Princeton, and Monmouth. The Continental Congress, too, had made its home in Philadelphia, with brief periods of exile when chased out by the British. Beyond the Revolution, Pennsylvanians also looked to the French-Indian War as a source of pride. The ill-fated Braddock expedition, where French and Indian allies had wiped out a British force, thereby precipitating the Seven Years' War, and the successful assault of John Forbes on the French fort at Duquesne at the Forks of the Ohio, which secured safety for the Pennsylvania and Virginia backcountry from French and Indian raids, had all transpired in the Pennsylvania back country. In the light of the Revolution, the FrenchIndian War took on the aura of a precursor. As they saw it, American heroism and fortitude in the face of savage Indian and French attacks had resulted in the expulsion of craven French aristocracy from the continent amid British bumbling and brutality.

\footnotetext{
${ }^{37}$ For Washington's legacy in the American military tradition, see: Marcus Cunliffe, Soldiers \& Civilians: The Martial Spirit in America 1775-1865 (New York: The Free Press, 1968) and Don Higginbotham, George Washington and the American Military Tradition (Athens: University of Georgia Press, 1985).
} 
The significance Pennsylvania and New Jersey troops found in the locations in and around which they grew up belonged to the burgeoning practice of Revolutionary battlefield tourism in the early republic. As historian Thomas A. Chambers has shown, initially tourists focused on the sites in the Niagara corridor--Ticonderoga, Saratoga, and Fort Niagara--with their journeys facilitated by a burgeoning transportation network. The natural scenery, increasingly important in the Romantic era, drew visitors as much as the battlefields themselves. As Chambers noted, "the Romantic impulse toward nostalgic reflections on landscape and history allowed tourists to express their membership in a cultural elite conversant in the vocabulary of the picturesque but also interested in their nation's origins and unique character." But, as he has also noted, during the sectional crises of the 1850s, the ways in which Americans experienced battlefields changed. As he explained, "meaning became increasingly localized and political, as broader memories of a gauzy Revolution of brave soldiers and tragic battles fought on scenic battlefields was relegated to secondary importance;" battlefields became places where people expressed diverging sectional nationalisms. ${ }^{38}$ With so many battlefields in their own backyards, troops from Pennsylvania and New Jersey focused on the contributions of their states to the overthrow of aristocracy during the Revolution.

Beyond the sites of the battles that Pennsylvanians and New Jerseyans might have visited, the memory of the Revolution permeated print culture in these states. Books weighed down the shelves, relating the heroic deeds of Washington and his compatriots. Francis Parkman's The Conspiracy of Pontiac told, in a romantic fashion, of the Indian

\footnotetext{
${ }^{38}$ Thomas A. Chambers, Memories of War: Visiting Battlegrounds and Bonefields in the Early American Republic (Ithaca, NY: Cornell University Press, 2012), 11,184.
} 
struggle in the backcountry that had followed the French-Indian War. The popular "pictorial field-books" of Benson Lossing provided readers with descriptions of the battles of the Revolution and the War of 1812 in the form of travelogues. Lavish illustrations of the battlefields, relics, and ruins that accompanied them increased interest among readers. ${ }^{39}$ In popular magazines, accounts of battlefield tourism circulated widely, especially those of Virginian David Hunter Strother, who wrote under the pseudonym of Porte Crayon. ${ }^{40}$ Pennsylvania and New Jersey lay firmly within mainstream circuits of the book and magazine trade in the East, so these works found wide audiences there. ${ }^{41}$

\footnotetext{
${ }^{39}$ Lossing travelled widely, collecting both stories and pictures to include in his account, ranging from lower Canada to South Carolina. Instead of presenting a chronological history, he organized his books so that they followed his travel itinerary. As one historian has noted, they gave "a combination of solid
} historical research and engaging travelogue that contemporaries found attractive." Published in thirty installments, or "numbers," and then issued as two volumes in 1850-1852, the Pictorial Field-Book of the Revolution had sold 11,431 numbers, 1,541 copies of volume one, and 1,990 copies of volume two by 1856; Harold E. Mahan, Benson J. Lossing and Historical Writing in the United States 1830-1890 (Westport, CT: Greenwood Press, 1996), 55, 63.

${ }^{40}$ David Hunter Strother wrote a series of travel accounts of his journeys in Virginia, North Carolina, and New England that were published in Harper's Monthly Magazine during the 1850s. He discussed visiting several different Revolutionary War battlefields. Chambers, 101-05; and Cecil D. Eby, Jr., "Porte Crayon": The Life of David Hunter Strother (Chapel Hill: University of North Carolina Press, 1960), 73-96.

${ }^{41}$ At the start of the $19^{\text {th }}$ century, Philadelphia stood as the most important city in the American book trade; according to an 1804 catalogue of books printed in America, it outstripped both Boston and New York in absolute numbers of books printed. By the mid-19th century, both Boston and New York surpassed Philadelphia, which nevertheless remained quite important with more than 100 printing firms of various sizes in 1850 (by 1880 the number of firms approached 300). By 1880, Pennsylvania as a whole had more booksellers, stationers, and news agents than any other state in the Union except for New York. Thus, 
With thoughts of the Revolution circulating so widely, soldiers sought symbolic ties to the Revolution before they reached Virginia. As troops mustered into their regiments and marched to war, cities brought out long-sequestered relics. Benjamin Theodore Parks recalled that on the way to the front, his regiment mustered in front of "three peices of ordnance... brought from France by Gen, Leayfaette during the revolution" that had been stamped with "the French Coat of Arms." ${ }^{42}$ Lieutenant Colonel William J. Bolton of the 51st Pennsylvania Infantry Regiment wrote of a camp ground in Annapolis, Maryland, where "French troops during the Revolution" had "encamped on this very same ground. There were stoneheads and foot-marks on our drill grounds." ${ }^{43}$ Private Oliver Willcox Norton of the 83rd Pennsylvania Infantry Regiment mustered into service at Camp Wilkins in Pittsburgh, near which stood the ruins of Fort Pitt, the British structure that had replaced the French fort at Duquesne. Norton reported seeing "eight

residents of Pennsylvania enjoyed broad access to popular printed matter. James N. Green, "The Rise of Book Publishing," in The History of the Book in America: Volume 2: An Extensive Republic: Print, Culture, and Society in the New Nation 1790-1840, edited by Robert A. Gross and Mary Kelley (Chapel Hill: University of North Carolina Press, 2010), 94; Bruce Laurie, "Labor and Labor Organization," in A History of the Book in America: Volume 3: The Industrial Book 1840-1880, edited by Scott E. Casper, Jeffrey D. Groves, Stephen W. Nissenbaum, and Michael Winship (Chapel Hill: University of North Carolina Press, 2007), 74; and Michael Winship, "The National Book Trade System," in Casper, et al., History of the Book in America: Volume 3, 124.

${ }^{42}$ Benjamin Theodore Parks to Henry C. Eyer, June 1861 in Russ, "Civil War Letters Concerning Members of Co. G, 174th Reg. P.V.I.," 182.

${ }^{43}$ William J. Bolton diary entry, November 20, 1861 in The Civil War Journal of Colonel William J. Bolton, 51st Pennsylvania, April 20, 1861-August 2, 1865, edited by Richard A. Sauers (Conshohocken, PA: Combined Publishing, 2000), 33. 
guns and a lot of balls that were taken in the Revolution. One of the guns was marked W. Bowen, fecit 1747, two others ditto 1755, one 1776 and two made in Paris." The site so fascinated Norton, that in the fashion of tourists everywhere, he took "just for curiosity" a "piece of bark from a log in the old fort...built more than one hundred years ago." ${ }^{44}$ Private Jacob Heffelfinger of the 7th Pennsylvania Reserves (36th Pennsylvania) Infantry Regiment reported that Camp Curtin was "within three miles of the Brandywine battle ground." Visiting it, he was surprised that "the old Birmingham Quaker Meeting house is still standing" and that "it was used as a hospital during the battle." He observed "a large black spot on the solid oak floor, which some of the old citizens insist was caused by blood." Wandering about the larger battlefield, he visited "the hill on which Lafayette was wounded" and saw "the woods into which the Americans retreated." ${ }^{45}$ New Jersey troops formed up outside of Washington, D.C., in Camp Trenton or Camp Monmouth, named after the battles of the Revolutionary War. ${ }^{46}$ Beyond just seeing themselves as the

\footnotetext{
${ }^{44}$ Oliver Willcox Norton to Sister L., May 10, 1861 in Oliver Willcox Norton, Army Letters 1861-1865, Being Extracts from Private Letters to Relatives and Friends from a Soldier in the Field During the Late Civil War with an Appendix Containing Copies of Some Official Documents, Papers and Addresses of a Later Date (Chicago: O. L. Deming, 1903), 10-11.

${ }^{45}$ Jacob Heffelfinger to Sister, June 15, 1861 in "'Dear Sister Jennie--Dear Brother Jacob': The Correspondence Between a Northern Soldier and His Sister in Mechanicsburg, Pennsylvania, 1861-1864," edited by Florence C. McLaughlin, The Western Pennsylvania Historical Magazine Vol. 60 No. 2 (April
} 1977), 112.

${ }^{46}$ Robert McAllister to Ellen, July 11, 1861 and Robert McAllister to Ellen, July 13, 1861, in The Civil War Letters of General Robert McAllister, edited by James I. Robertson, Jr. (reprint, Baton Rouge: Louisiana State University Press, 1998 [1965]), 40-41. 
inheritors of the Spirit of '76, soldiers literally walked in the footsteps of their Revolutionary-era forefathers.

Soldiers sought to sustain these ties to the early heroes of the Republic throughout the war. Levi Bird Duff sent home "some flowers" he had picked "from the garden of Chief Justice John Marshall, formerly of the Supreme Court of the U.S." He explained that Marshall "was one of the most celebrated American jurists. His residence was in Fauquier County near Piedmont." ${ }^{47}$ On Virginia's Peninsula, Sergeant E. N. Boots of the 101st Pennsylvania Infantry Regiment spent time investigating Virginia's colonial history. He reported that "Williamsburg is the oldest corporate town in Va. its charter dates back to 1735. It is also the seat of William \& Mary's College, except Yale, the oldest college in the United States." Aside from this inaccurate assessment, Boots found the town much more significant for the "place of burial of the Custis family" because of their association with "Martha Custis: the wife of Washington." Drawing a connection between the past generation and the current one, he noted that further down the Peninsula, "the white house, which stands on the spot that the old mansion did, where Washington, on his way to Williamsburgh, stopped for the night \& saw her who afterwards became his wife" served as the headquarters of Army of the Potomac commander Major General George B. McClellan. ${ }^{48}$

As E. N. Boots's account makes clear, soldiers sought out sites associated with George Washington more than any other. While Marshall might have been a celebrated

\footnotetext{
${ }^{47}$ Levi Bird Duff to [Wife], July 26, 1863 in Helmreich, , To Petersburg with the Army of the Potomac, 136.

${ }^{48}$ E. N. Boots to Mother, May 20, 1862 in "Civil War Letters of E. N. Boots, Virginia 1862," edited by Wilfred W. Black, Virginia Magazine of History and Biography Vol. 69 No. 2 (April 1961), 200.
} 
jurist, or the antiquity of the College of William and Mary fascinating, Washington stood as the pinnacle of American patriotism. Sites connected with the father of the country attracted more soldiers than others. Alonzo B. Searing took a trip to "the Court House where General Washington used to transact business" in Fairfax. ${ }^{49}$ He later visited the Episcopal Church in Alexandria, noting that "the building is nice, but a very old one, for it is the same in which General Washington used to attend when he lived at Mount Vernon. His name is carved upon the pew in which he used to sit." ${ }^{50}$ James Rush Holmes of the 61st Pennsylvania Infantry Regiment took a great interest in Pohick Church, because, as he explained to his sister, it was "the church Washington was married in." He pried "a piece of wood off his Pew" and recorded that "his name is on the door. It is a verry antique place." ${ }^{51}$ Private Joel Molyneux of the 141st Pennsylvania Infantry Regiment sought out Arlington House in Virginia because "some of Washington's family once lived there--the Custisses." ${ }^{52}$ In Fredericksburg, troops sought out the monument for Mary Washington, mother of George. Sergeant A. F. Hill of the 8th Pennsylvania Reserves (37th Pennsylvania) Infantry Regiment became curious after seeing "a marble column, about fourteen feet in height" that stood somewhat incongruously "in a green

\footnotetext{
${ }^{49}$ Alonzo B. Searing to Sister, November 17, 1862, in O'Shaughnessy, Alonzo's War, 24.

${ }^{50}$ Alonzo B. Searing to Sister, July 31, 1864 in O'Shaughnessy, Alonzo's War, 160.

${ }^{51}$ James Rush Holmes to Sister, November 13, 1861 in "The Civil War Letters of James Rush Holmes," edited by Ida Bright Adams, The Western Pennsylvania Historical Magazine Vol. 44 No. 2 (June 1961), 113.

${ }^{52}$ Joel Molyneux to Brother, October 9, 1862 in Quill of the Wild Goose: Civil War Letters and Diaries of Private Joel Molyneux, 141st Pennsylvania Volunteers, edited by Kermit Molyneux Bird (Shippensburg, PA: Burd Street Press, 1996), 42.
} 
field." He found out that it marked "the spot where the mother of Washington was buried" and resolved to visit it. To his distress, the monument had been "spattered over with hundreds of bullets and shot--that the rebels, during their possession, had been amusing themselves by discharging their muskets against it! What desecration!" ${ }^{53}$ Here, Hill began to draw a more explicit link between the Revolution and the current war. The Confederates, through their actions, desecrated not only the ideals of the Revolution but also the actual antiquities and locations associated with it.

The site that provoked soldiers to reflect on the past in the present more than any other was George Washington's home on the Potomac, Mount Vernon. Troops from Pennsylvania and New Jersey made repeated visits to the site, collecting plants and objects in order to obtain a physical tie to Washington. Captain Jacob W. Greenawalt of the 105th Pennsylvania Infantry Regiment sent home to his wife "a small Cedar Tree which I pulled up a few steps from the Tomb of Washington on Mount Vernon." He instructed her to plant it in a safe spot at home and nourish it well, for "I value it high not so much on account of the tree itself as the sacred soil upon which its germ was nourished and sprang." ${ }^{54}$

Lieutenant Colonel Robert McAllister of the 1st New Jersey Infantry Regiment also made a pilgrimage to Mount Vernon. He mailed to his daughters "three Geranium plants which you will find placed between the leaves from some book. The two large ones are from the flower garden at Mount Vernon...The small leaf was presented to me

\footnotetext{
${ }^{53}$ A. F. Hill, Our Boys. The Personal Experiences of a Soldier in the Army of the Potomac (Philadelphia: John E. Potter, 1864), 244-45.

${ }^{54}$ Jacob W. Greenawalt to Wife, November 23, 1861 in Edwin P. Hogan, Waiting for Jacob: A Civil War Story (Latrobe, PA: Saint Vincent College Center for North Appalachian Studies, 2000), 43-44.
} 
the same day as I was riding to our outpost pickets." He told them that "the Mount Vernon plants I call Union, and the little delicate plant I call Secession. I hope it will soon be smothered by the grate overpowering plants of the Union." The larger geraniums, grown in the soil of Washington's homestead, demonstrated the strength of the Union that he had fathered, while the smaller plant from the edge of enemy territory represented the weakness of the rebellion. McAllister also sent his wife "a Geranium stem which I got at Mount Vernon." As with Greenawalt, McAllister instructed his wife to "take good care of it, plant it in a pot, and cultivate it will all care and attention." He explained that: "I got it from the garden planted by Washington. It was given to me by the old negro who went with Genl Lafayette to the tomb of Washington when the General went to commune with his old friend in that solemn place." In addition to the geranium, he also enclosed "large leaves from a bush brought by Genl. Lafayette and presented to Washington," along with "a large stone I picked up on the shore of the river at Mount Vernon," "a small pebble...from Washington's tomb," and "small berries...from the outside" of it. ${ }^{55}$ Both Greenawalt and McAllister venerated Washington, but found great significance in connecting themselves to the living legacy of Washington's plants.

Other soldiers who visited Mount Vernon sought a similar physical connection to the sacred site. They also used the opportunity to opine on how Washington stood as an exemplar of Union, while the Confederates had perverted his legacy. A. F. Hill "learned that Mount Vernon was within our lines" and "resolved to visit the interesting spot." Once there, he wandered around the property until coming upon Washington's tomb. He

\footnotetext{
${ }^{55}$ Robert McAllister to Daughters, October 29, 1861 and Robert McAllister to Ellen, November 22, 1861 in Robertson, The Civil War Letters of General Robert McAllister, 88, 97.
} 
recalled that "I could scarcely realize that I was actually gazing upon what contained the mouldering bones of the adored hero." Feeling a deep connection to the site, Hill "snatched a small twig from a vine which hung from the wall" in order to carry something with him to render that link tangible. As he left to return to camp, he reflected with sorrow: "What would be [Washington's] feelings, as the sound of the cannon employed in civil strife shook the walls of his peaceful home--when the sharp crack of the rifle in the hands of a Virginian was the death-signal of some native of Virginia's sister state! Surely, his heart would be broken!" ${ }^{56}$ Drawn by the site, Hill made repeated visits, eventually paying the twenty-five cent fee to tour the interior of the plantation house, where he saw "many interesting sites" and artifacts such as "the ponderous iron key, which, we were told, was once the key of the Bastile in which La Fayette was confined." 57

Other soldiers, even though they could not visit Mount Vernon or the tomb of Washington's mother, commented on them as symbols of Washington that tied soldiers back to the hero of the nation. Much like A. F. Hill, they used such sites to cement their ties to Washington and the Union. Reverend Andrew Jackson Hartsock of the 133rd Pennsylvania Infantry Regiment caught sight of the hallowed mansion and tomb as he passed along the Potomac on board a ship. He confided in his diary: "What strange feelings and thoughts present themselves when one looks upon the Resting place of

\footnotetext{
${ }^{56}$ Hill, Our Boys, 191-96.

${ }^{57}$ Hill, Our Boys, 223.
} 
Washington. How striking, his sepulchre on the line that now divides our country." ${ }^{15}$ Oliver Willcox Norton remarked, after a soldier in his regiment died while encamped near Mount Vernon, "Half a dozen miles off sleep the ashes of the 'Father of the Country'. The world admires and honors him, and weeps over his grave, and yet, who can say that Adam Pickard, in his humble sphere, did not do his duty to his country as well as the immortal Washington." ${ }^{59}$

Chaplain H. W. Stuckenburg of the 145th Pennsylvania Infantry Regiment, in a sermon delivered on Washington's birthday, similarly tied the sacrifices of soldiers in the current war back to Washington's selfless devotion to his country. He "thought of basing my remarks on Ps 145 4th v 'One generation shall praise thy works to another, and shall declare thy mighty acts.' And what a fine opportunity is presented to the orator here to impress upon his hearers the greatness of Washington, the nobleness of his nature and the immortality of his deeds." The tie between the Psalm and Washington was enhanced because "We are within sight of the tomb of the Mother that gave him birth...It is still in the possession of and surrounded by those rebels who are intent on destroying the government and union Washington fought so long, so bravely, so believingly, and under such adverse circumstances, to establish." He continued that "We are fighting for our country, our laws and our rights...Today the Spirit of Washington lives again in our country." He ended his sermon with the supplication: "God of Washington be our God!

\footnotetext{
${ }^{58}$ Andrew J. Hartsock diary entry November 30, 1862, in Soldier of the Cross: The Civil War Diary and Correspondence of Rev. Andrew Jackson Hartsock, edited by James C. Duram and Eleanor A. Duram (Manhattan, KS: Military Affairs/Aerospace Historian, 1979), 34.

${ }^{59}$ Oliver Willcox Norton to Cousin L., February 11, 1862 in Norton, Army Letters 1861-1865, 52.
} 
Thou hast given us the Father of our country--give us a preserver also." ${ }^{60}$ For these troops, proximity to sites associated with Washington cemented their abstract commitment to the Constitution, law, and Union. Pilgrimages to, and sightings of, such Revolutionary shrines and sepulchers sanctified their cause and allowed soldiers to collect relics that provided a physical manifestation of the past.

When the Army of the Potomac found itself near Yorktown in 1862, Pennsylvania and New Jersey soldiers began to bind their war even more tightly to the heritage of the Revolution. The Union siege of Yorktown took place on the same ground where nearly 80 years earlier Washington, with the help of the French, forced the surrender of Charles Cornwallis and the British. In the popular imagination, the surrender of Cornwallis ended the American Revolution. Soldiers realized this and avidly sought souvenirs of the past, similar to the ways in which civilians in Pennsylvania drew upon their Revolutionary heritage. ${ }^{61}$

${ }^{60}$ John H. W. Stuckenberg diary entry, February 22, 1862 in David T. Hederick and Gordon Barry Davis, Jr., I'm Surrounded by Methodists...Diary of John H. W. Stuckenberg, Chaplain of the 145th Pennsylvania Volunteer Infantry (Gettysburg: Thomas Publications, 1995), 53-55.

${ }^{61}$ On the home front, a similar process that tied the Civil War to the American Revolution emerged. Historian Elizabeth Milroy has shown that at the United States Sanitary Commission fair in Philadelphia in 1864, organizers selected artwork with patriotic themes that would resound in Pennsylvania and the Delaware Valley. Designed to raise money to support the activities of the Sanitary Commission, the fair put on display numerous artifacts and works of art calculated to excite patriotic fervor. Civilians could see weapons from the Revolutionary War, more recent relics from the Civil War, and a uniform purported to have been worn by George Washington. Also on display were other items associated with the father of the country, including a spoon rumored to have come from Mount Vernon. Among the most imposing pieces of artwork on display was Emanuel Leutze's "Washington Crossing the Delaware." It was joined by Peter 
James Rush Holmes noted that "Wee are encamped near Yorktown where Lord Cornwallis gave up his sword to Gen. Washington \& I think what M Clellan has worked so long about here, he intends to have another of the same sort." ${ }^{62}$ Levi Bird Duff remarked that "the house near which we were...is the same in which Lord Cornwallis, signed articles of capitulation to Washington...I enclose to you a couple of flowers plucked from the garden in the rear of the house." 63 Oliver Willcox Norton also noticed "this is historical ground. As long ago as 1781 Yorktown was surrendered, and here is the very place it was done. Just back of me is a long bank of earth now overgrown with trees, a breastwork thrown up by Washington's men." ${ }^{64}$ He set about collecting souvenirs that embodied both the Revolution and the Civil War; "when I was out on picket I cut a hickory stick that grew on Washington's old breastwork. I picked up a secesh bullet too and brought them into camp. I thought I would make something out of them to remember

Rothermel's "State House on the Day of the Battle of Germantown," which "clearly and emphatically used local history to urge upon viewers the need for immediate political action through financial sacrifice...[T]he composition effectively urged Northern women to follow in the footsteps of their Revolutionary foremothers. It also demonstrated the elegant interweaving of genealogy and public historian cherished by many members of Philadelphia's old families." Pennsylvanians took pride in their connection to the Revolution, and used that pride to sustain their commitment to the Union, both on and off the battlefield. Elizabeth Milroy, "Avenue of Dreams: Patriotism and the Spectator at Philadelphia's Great Central Sanitary Fair," in Making and Remaking Pennsylvania's Civil War, edited by William Blair and William Pencak (University Park: The Pennsylvania University Press, 2001), 35, 37, 40, 45.

${ }^{62}$ James Rush Holmes to Janey, April 15, 1862 in Adams, "The Civil War Letters of James Rush Holmes," 116.

${ }^{63}$ Levi Bird Duff to [Wife], April 23, 1862 in Helmreich,, To Petersburg with the Army of the Potomac, 53. ${ }^{64}$ Oliver Willcox Norton to Sister L., April 23, 1862 in Norton, Army Letters 1861-1865, 71-72. 
Yorktown by, so I whittled out a tatting needle and made a rivet of the bullet." ${ }^{65}$ Others in the regiment availed themselves of the opportunity to collect relics: "since we have come the boys have gone to making pipes of the laurel roots that grow on the old breastwork thrown up in the Revolution. I have one that I think a great deal of." ${ }^{66}$ For troops from Pennsylvania and New Jersey, associations with the Revolution, at Yorktown or elsewhere, strengthened their commitment to their struggle in the present. The past bled into the present for them. ${ }^{67}$

${ }^{65}$ Oliver Willcox Norton to Sister L., April 27, 1862 in Norton, Army Letters 1861-1865, 74.

${ }^{66}$ Oliver Willcox Norton to Cousin L., May 1, 1862 in Norton, Army Letters 1861-1865, 76.

${ }^{67}$ Historian Michael Degruccio has written about how soldiers sought out physical manifestations of their experiences by collecting relics at their own battlefields. He argued that "Americans...came to believe that they could somehow capture the war's essence by holding small objects, gathered just after battle, in the palms of their hands." Degruccio saw that these actions "directly or indirectly reflect fundamental belief patterns of individuals and the larger society." As such, relics, and their collection, demands thoughtful and thorough consideration. Likewise, historian Megan Kate Nelson has examined how soldiers collected relics of both curiosity and combat, although she confined her discussion to their collection of contemporary artifacts. She noted that "when sending home souvenirs, Civil War soldiers anticipated their futures, dreaming about afternoons spent sifting through boxes of war relics and reactivating the vivid memories of what for many of them were the seminal moments of their lives." Both DeGruccio and Nelson, by confining their discussion to relics of Civil War battles, overlook how the practice of collecting relics and mementos during the Civil War linked to soldiers' desires to feel a connection to the Revolutionary generation. By extension, when soldiers treated they own battlefields the same as they did sites associated with Washington and the Revolution, they made the implicit connection that their struggle was just as monumental and important as the Revolution in America's history. Michael DeGruccio, "Letting the War Slip Through Our Hands: Material Culture and the Weakness of Words in the Civil War Era," in Weirding the War: Stories from the Civil War's Ragged Edges, edited by Stephen Berry (Athens: University of 
Soldiers found ways to connect their own battlefields to sites associated with the Revolution. Their visits to places where Washington had worshipped, married, fought, or lived deepened their identification with the Revolution. When they visited their own battlefields, they saw the Civil War in similarly heroic terms. They justified their continued fighting on the basis of their already shed blood. For them, the Army of the Potomac became almost a cause unto itself, as its continued struggles to preserve the laws and the Constitution elevated it to a mythic status, in the same way that Washington and the Continental Army symbolized the Revolution and all that it stood for. The Army of the Potomac travelled repeatedly over the grounds of its earlier battles: for instance, both the Union and Confederate armies passed over the Manassas battlefield in 1862; in 1863 they revisited the grounds of First and Second Manassas; and in 1864, soldiers passed over the old Chancellorsville battlefield. Such occasions provided soldiers an opportunity to reflect on the immediate past

In 1862, A. F. Hill "determined to see the Bull Run battle-ground." Once there he toured "interesting spots" of "the terrible battle of the previous summer." He collected "relics" including "an old bullet, a small stone, a piece of cornstalk, and a small twig." 68 John Strathern of the 8th Pennsylvania Reserves (37th Pennsylvania Infantry) Regiment visited Manassas and it made a great impression on him. He wrote that "space will not permit me to give any adequate idea of the ground. Suffice it to say that from the number

Georgia Press, 2011), 22, 27; and Megan Kate Nelson, Ruin Nation: Destruction and the American Civil War (Athens: University of Georgia Press, 2012), 157, 230.

${ }^{68}$ Hill, Our Boys, 212-14. 
of graves both [sides] must have suffered." ${ }^{69}$ He also took care to point out for his family the role that fellow Pennsylvanians had played. ${ }^{70}$ Jacob Heffelfinger ranged widely over the battlefield, describing how "the ground is thickly strewn with skeletons of horses, together with pieces of clothing, haversacks, knapsacks, boots, shoes, saddles \&c." He observed piles of bones and commented, "I could have easily gathered a bushel." 71

While the first major battle of the Army of the Potomac attracted soldiers, they reserved their deepest meditations for Chancellorsville. The battle, which took place in 1863, had been one of the lowest moments for the Army of the Potomac. Major General Joseph Hooker had launched an assault that promised to destroy Robert E. Lee's Army of Northern Virginia. At a critical moment, he lost his nerve and ceded the initiative to Lee, who took full advantage of that opportunity. With Hooker's army swatted aside, Lee launched an invasion of the North until stopped at Gettysburg. The horrors of the fight at Chancellorsville made an impression on Union soldiers, as many wounded had died in fires in the woods following the confused fight. For many, Chancellorsville had been the night at its darkest, just before the dawn at Gettysburg. Because of these factors, when soldiers passed over the same area in 1864, they made sure to visit the sites of their past.

\footnotetext{
${ }^{69}$ John Strathern to Father, April 14, 1862 in The Civil War Letters of Cpl. John H. Strathern, Eighth Pennsylvania Reserve Volunteer Corps, compiled by Marlene C. Bumbera (Apollo, PA: Closson Press, 1994), 59.

${ }^{70}$ John H. Strathern to Father, April 22, 1862 in Bumbera, The Civil War Letters of Cpl. John H. Strathern, 61.

${ }^{71}$ Jacob Heffelfinger to Sister Jennie, April 15, 1862 in McLaughlin, "'Dear Sister Jennie--Dear Brother Jacob'," 133.
} 
Alonzo B. Searing encamped near Chancellorsville in May 1864. He, and others, ventured out to find "the position where we fought last year." They found the site, and observed "scattered around...broken guns, battered canteens, torn pieces of knapsacks, haversacks, and shreds of clothing; but saddest of all, in every direction, bleaching in the sun lay the skulls and bones of our dead comrades." Among the nameless masses at that sylvan Golgotha, the New Jersey men identified the mortal remains of Corporal David Bender. Bender had, "on the under part of the leather visor of his cap, with an iron stamp, ...plainly marked his name, company, and regiment." During the battle "a bullet pierced the leather visor of Bender's cap, entering his head and causing instant death." Amid the mass of bones, Searing and his compatriots found "Bender's skull," identifiable because of the bullet hole through it, still "with the cap on it." Recovering the cap, Searing "took it and cut off the leather visor, showing [Bender's] name and marks of the deadly bullet. I intend to send or bring it home, as a memento of the terrible fight." ${ }^{72}$

Levi Bird Duff found the spot on the battlefield where his regiment's colonel had fallen. He "dismounted and culled these small purple (4 leaf) flowers which I enclose you. The other flowers which I enclose we collected on the hottest part of the field \& are sent to represent the battleground of Chancellorsville in your collection." ${ }^{73}$ Robert McAllister, then colonel of the 11th New Jersey Infantry Regiment, saw the grim sights of "the bones of our dead laying and bleaching on top of the ground." To his wife he sent "two or three pretty violets and flowers that I picked up on the very ground where my

\footnotetext{
${ }^{72}$ Alonzo B. Searing to Sister, May 11, 1864 in O'Shaughnessy, Alonzo's War, 151-52.

${ }^{73}$ Levi Bird Duff to [Wife], May 4, 1864 in Helmreich, To Petersburg with the Army of the Potomac, 188.
} 
regiment stood and fought so splendidly. The ground was made rich by the blood of our brave soldiers. I thought the flowers would be a relick prised by you." 74

These three soldiers described their visits to their own battlefields in the terms in which they had talked about Washington and the Revolution. Just as the soil around Washington's tomb at Mount Vernon had nourished flowers that represented the Union, so had the blood of the brave Union troops nourished the ground of the nation. These soldiers had placed their own battles on the same pedestal upon which they had placed Washington. The flowers and other relics made a statement that the troops from Pennsylvania and New Jersey had performed just as much of a service to the country as Washington, the patriot exemplar. ${ }^{75}$ Their discussions of Washington and the Revolution also underscored how the slaveholding oligarchy of the South had betrayed the Revolution. Some soldiers from New Jersey and Pennsylvania had sought to tie their

\footnotetext{
${ }^{74}$ Robert McAllister to Ellen, May 4, 1864 in Robertson, The Civil War Letters of General Robert McAllister, 415.

${ }^{75}$ The collection of souvenirs and the ways in which soldiers linked themselves to the Revolution might be seen as an early instance of battlefield tourism. But these soldiers, while keen to secure relics of both the Revolution and the Civil War, often expressed little interest in preserving their battlefields as a whole. For a discussion of early battlefield preservation, which was linked with the movement to establish national cemeteries, see: John R. Neff, Honoring the Civil War Dead: Commemoration and the Problem of Reconciliation (Lawrence: University Press of Kansas, 2005), 16-65; Timothy B. Smith, A Chickamauga Memorial: The Establishment of America's First Civil War National Military Park (Knoxville: University of Tennessee Press, 2009), 7-11; and Timothy B. Smith, The Golden Age of Battlefield Preservation: The Decade of the 1890s and the Establishment of America's First Five Military Parks (Knoxville: University of Tennessee Press, 2008), 11-23;
} 
cause to the Revolution, seeing themselves as latter-day patriots excoriating resurgent aristocracy from America.

The fascination with the historic landscape of Virginia demonstrated by Pennsylvania and New Jersey troops meshed with their admiration for Virginia's natural beauty. In particular, they found the Shenandoah Valley and northern Virginia sublime. The landscape appeared much the same as the farms in their state, with diversified agriculture and small-holding farms, albeit in the South, these farms relied upon enslaved African American labor. Crucially, the Valley and northern Virginia showed soldiers a landscape similar to their own; unlike soldiers from the West, Pennsylvania and New Jersey troops serving in the East could look upon the South without seeing the seeds of their own degradation in the slaveholding regime. The identification of Virginia with Washington, and the generally familiar landscape, put off soldiers in the East less than it did in the West. Inclined to view Virginia through rose-tinted lenses, Pennsylvania and New Jersey troops found less opportunity to fixate upon the "poor white trash," which embodied the deepest fears of how the Slave Power sought not only to enslave the African but also the white northerner.

As several scholars have noted, soldiers often viewed the landscape of Virginia as a hostile force to be reckoned with. The lushly forested area outside of Fredericksburg-the infamous Wilderness--with its second-growth forest thickets and tangles of brush, snared more than one Union army. As environmental historian Aaron Sachs has written, "almost every commentator mentioned the seeming impenetrability of the understory, the briery maze, thick with dead leaves, that led sometimes to dark groves of oak and pine, sometimes to bright swaths of pink lady's slippers, sometimes to smoking muskets." The 
Wilderness, and soldiers' experiences with nature in general, imparted several meanings; nature could signal rejuvenation and growth, or it could be threatening, confusing, and deadly. Historian Megan Kate Nelson, as well, has found that nature provided soldiers a canvas on which to project the war. She has found that "both trees and men's bodies became wartime ruins, blown into pieces that despite their fragmentation could be 'read and understood by all."' ${ }^{76}$ All of these scholars see the Civil War--with its concomitant death and destruction--reflected in and through nature. Kathryn Shively Meier has also examined how self-care among Confederate and Union soldiers changed based upon the environmental and disease hazards encountered on Virginia's Peninsula and in the Shenandoah Valley. ${ }^{77}$

Yet discussion of how soldiers interpreted landscapes needs to consider what they omitted. Namely, some soldiers from New Jersey and Pennsylvania could look over the bucolic beauty of Northern Virginia and the Shenandoah Valley and see a productive region without feeling the need to point out that the institution of slavery had corrupted the landscape. These Pennsylvania and New Jersey troops saw the Valley and Northern Virginia as landscapes not dissimilar from their own, and as the residence of Washington and other heroes. Instead of seeing Virginia as a landscape rendered hostile and

\footnotetext{
${ }^{76}$ For more discussion on the Battle of the Wilderness, see Stephen Cushman, Bloody Promenade: Reflections of a Civil War Battle (Charlottesville: University of Virginia Press, 1999). Aaron Sachs, Arcadian America: The Death and Life of an Environmental Tradition (New Haven: Yale University Press, 2013), 151; and Nelson, Ruin Nation, 159.

${ }^{77}$ Kathryn Shively Meier, Nature's Civil War: Common Soldiers and the Environment in 1862 Virginia (Chapel Hill: University of North Carolina Press, 2013), 35-64.
} 
unproductive by the institution of slavery, they saw it as a beautiful area with its fertility ravaged by the hard hand of war.

Chaplain John H. W. Stuckenberg wrote of the Shenandoah Valley: "Far as the eye could reach were seen hills and valleys, woods and fields, meadows and waving grain, houses and barns and villages and through field glass, at the foot of the mountain was seen Winchester. Grand scenes awaken grand thoughts, the thoughts of eternity, infinity, God. ${ }^{17}$ Lieutenant Edward R. Geary of Knap's Independent Battery E, Pennsylvania Light Artillery commented: "The country around here surpasses all my imagination had ever pictured. ${ }^{179}$ Major John Wilson Phillips of the 18th Pennsylvania Cavalry Regiment also found the Valley "a beautiful region. I have rarely seen it equaled in fertility and beauty. The war with all its destruction cannot keep it down." ${ }^{80}$ Reverend Andrew Jackson Hartsock commented that the Valley "is rich, abounds with good houses. ${ }^{181}$ Rather than appearing as a threatening landscape, infected with slavery, the Valley elicited typical Victorian reactions to the sublime. To them, it seemed a fecund, natural idyll, notwithstanding the hard hand of war. Instead of reflecting upon how

\footnotetext{
${ }^{78}$ John H. W. Stuckenberg diary entry, July 24, 1863 in Hederick and Davis, I'm Surrounded by Methodists, 94.

${ }^{79}$ Edward R. Geary to Mother, June 3, 1862 in Hurrah for the Artillery! Knap's Independent Battery "E", Pennsylvania Light Artillery, compiled by James P. Brady (Gettysburg: Thomas Publications, 1992), 119.

${ }^{80}$ John Wilson Phillips diary entry, August 18, 1864 in "The Civil War Diary of John Wilson Phillips," edited by Robert G. Athearn, Virginia Magazine of History and Biography Vol. 62 No. 1 (January 1954), 107.

${ }^{81}$ Andrew J. Hartsock diary entry, November 5, 1862 in Duram and Duram, Soldier of the Cross, 23.
} 
slavery might degrade local whites--and by extension themselves--soldiers looked with awe upon what nature had wrought.

Soldiers also held favorable opinions about towns in Virginia, seeing wellmaintained villages that bore little trace of degradation brought about by slavery. Alonzo B. Searing thought Leesburg "quite a large city with fine streets, pleasantly shaded with numerous trees." ${ }^{82}$ Captain Albert Heffley of the 142nd Pennsylvania Infantry Regiment discovered Warrenton to be "a fine place--beautiful dwellings." ${ }^{83}$ He considered "the country between our picket line \& Port Royal...one of the most beautiful that I've yet seen in Va. There are some magnificent buildings \& not a few pretty women." ${ }^{84}$ Private Aungier Dobbs of the 22nd Pennsylvania Cavalry Regiment described the environs of Winchester: "The country is open and I never saw more or better wheat than here in the Same space the buildings is large and fine and the Country looks to have been in flourishing condition." The town itself and its public works impressed Dobbs, who wrote: "Judging from the Residences and the nice houses the people are wealthy and Display a good bit of taste. The town is supplied with water from Springs in pipes." ${ }^{85}$ Levi Bird

\footnotetext{
${ }^{82}$ Alonzo B. Searing to Sister, June 24, 1863 in O'Shaughnessy, Alonzo's War, 80.

${ }^{83}$ Albert Heffley diary entry, November 5, 1862 in Civil War Diaries of Capt. Albert Heffley and Lt. Cyrus P. Heffley, Company F-142nd Regt. Penna. Vol. Army of the Potomac [edited by Earl E. Boyer] (Apollo, PA: Closson Press, 2000), 13.

${ }^{84}$ Albert Heffley diary entry, August 22, 1863 in Civil War Diaries of Capt. Albert Heffley and Lt. Cyrus P. Heffley, 44.

${ }^{85}$ Aungier Dobbs to Esther, March 20, 1862 in Ralph Haas, Dear Esther: The Civil War Letters of Private Aungier Dobbs Centerville , Pennsylvania, Company "A", The Ringgold Cavalry Company, 22nd Pennsylvania Cavalry, June 29, 1861 to October 31, 1865, edited by Philip Insley (Apollo, PA: Closson Press, 1991), 70.
} 
Duff wrote of the area just north of Richmond: "This is a very fine country and under a good state of cultivation. There is wheat \& rye growing here but the soil seems too light for them. Nearly all the cleared land is planted with some kind of grain, showing the revel government recognizing that the raising of food is an important object. The absence of stock of every description except a few negroes is a noticeable feature but it may have been driven off before our advance." 86

As Searing's description hinted, when troops from New Jersey and Pennsylvania encountered devastation across the landscape, they interpreted as the outcome of war, not the natural state of a slave-labor regime. They recognized that as large field armies moved to and fro, they stripped crops and livestock from farms, tore down fences and outbuildings, and generally ripped everything apart. Corporal Frederick Pettit of the 100th Pennsylvania Infantry thought that Virginia was "the richest farming country I ever saw." He attributed the desolation he saw to "a law of Congress" that said "all rebels... have no property rights." Union troops, taking the First and Second Confiscation Acts to heart, had carried out those policies to "the fullest extent." ${ }^{87}$ Instead of blaming the poor state of the land and its improvements upon anything intrinsic to slavery, Pettit saw the damage as the outgrowth of Union war policies. Though he found other parts of Virginia "less improved," he placed primary emphasis for that state of affairs on soldiers who had "taken everything." ${ }^{88}$ Levi Bird Duff discovered Fauquier County "generally

\footnotetext{
${ }^{86}$ Levi Bird Duff to [Wife], May 29, 1864 in Helmreich, To Petersburg with the Army of the Potomac, 197.

${ }^{87}$ Frederick Pettit to Parents, Brothers, and Sisters, November 8, 1862 in Infantryman Pettit: The Civil War Letters of Corporal Frederick Pettit, edited by William Gilfillan Gavin (New York: Avon Books, 1991), 32.

${ }^{88}$ Frederick Pettit to Parents, Brothers, and Sisters, November 11, 1862 in Gavin, Infantryman Pettit, 33.
} 
well improved" but "It was never before traversed by an army \& of course does not present the desolate appearance of other portions of Virginia." ${ }^{89}$ E. N. Boots thought that Virginia's Peninsula "presented a splendid appearance" and "in fact it is the most beautiful country I have ever seen." He blamed the run-down state of the farms around on "the rebel army" who had "destroyed things terribly in their retreat" toward Richmond. ${ }^{90}$ Robert McAllister, making his headquarters in an abandoned plantation mansion, opined that "the desolating hand of war has laid all around me a heap of ruins. The handsome mansion, barn and outbuildings, fences, and all have shared alike the fate of the destroying hand." Ever the horticulturalist, he bemoaned the fact that "the yard in front of the house, with its fine trees and garden, with its beautiful boxwood and flowers, are all demolished." 91

The tone of these soldiers shifted when they journeyed outside of the Eastern Theater. They noticed a stark difference between the institution of slavery as practiced in Virginia and elsewhere. Frederick Pettit, which had gone West with Major General Ambrose Burnside in 1863, observed "There is quite the difference between the Negroes in Kentucky and further south. Here they are contented generally to remain with their masters but this is not the case further south. They are anxious to be free, and hate their masters intensely. They scorn the idea of not being able to support themselves if free. I

\footnotetext{
${ }^{89}$ Levi Bird Duff to [Wife], November 8, 1862 in Helmreich, To Petersburg with the Army of the Potomac, 88.

${ }^{90}$ E. N. Boots to Mother, May 20, 1862 in Black, "Civil War Letters of E. N. Boots, Virginia 1862," 200.

${ }^{91}$ Robert McAllister to Family, January 7, 1862 in Robertson, The Civil War Letters of General Robert McAllister, 113.
} 
am satisfied that the Negroes are the cause of this war and this war will free them." 92 Leaving aside the fact that slavery remained legal in Kentucky, while Abraham Lincoln's Emancipation Proclamation had freed those enslaved "further south," Pettit's observation demonstrated that soldiers noticed differences between slave regimes.

Other troops found slavery in the West absolutely disgusting. The alien landscape, poor farms in the Appalachians, and vast plantations along the Mississippi Valley watershed startled these troops from Pennsylvania and New Jersey. Before their arrival in the West, as far as they had been concerned, Virginia had been their context for a slave society. The bucolic landscape of the Shenandoah Valley and improved, if a bit small, towns and cities had been familiar to them. Sights in Virginia had not led them to question the institution of slavery, or remark upon its effects on nearby whites. When these Pennsylvanians went West, they voiced different sentiments.

Edward Geary, part of Knap's Independent Battery E, Pennsylvania Light Artillery, journeyed with the Eleventh and Twelfth Army Corps to the West after the Gettysburg campaign. He professed himself aghast at the difference between slavery in Virginia and Tennessee. The battery made its headquarters "in one of the many forsaken houses" in the area. The "two ancient women, belonging to the class denominated 'white trash'" who lived in the house shocked him because they had "a large number of offspring which give unmistakeable signs that they have had various fathers." The supposed sexual profligacy of the "white trash" shook him. The African Americans he encountered also horrified him; he wrote "I have never witnessed anything so grotesque and amusing as the actions of our little black neighbors. They can all dance like a French dancing master,

\footnotetext{
${ }^{92}$ Frederick Pettit to Father, August 15, 1863 in Gavin, Infantryman Pettit, 99.
} 
and can change the expression of their features--in short, 'make faces', to resemble any animal from the negro to the monkey. The wenches are--as indeed all are in this place-the most bare faced strumpets." While Geary had seen black people in Virginia, none of them had provoked him to comment upon them in such a hostile and sustained fashion. Unlike the black people in Virginia, those in Tennessee seemed more bestial to Geary; they could imitate "monkeys" and displayed a troubling lack of sexual mores. Indeed, Geary remarked "I never believed the reports I have heard at home, of negro morals, until I reached this place. No one can imagine how debased they are until they get among them." This comment came from a man who had served for two years in the Army of the Potomac, during which time he had encountered large numbers of African Americans. Yet in the East, he had not thought that he had been "among them." Crucially, as well, Geary's description of his "little black neighbors" merged with his description of the "white trash;" both groups were degraded in the similar manner. He concluded by informing his mother that "A few months in this place would make an abolitionist out of almost any one." 93

The depth of Geary's sentiment can be judged from a letter he had written nearly a year earlier in reaction to the Emancipation. He had fulminated that "If this war is to be made the means of freeing the negroes and not the preservation of the Union, I wish to be considered out of business." He avowed: "I would sooner fight with the Southerners than with an army of abolitionists. The negro and the abolitionist are on par with one another, and both deserved to be driven out of this country." He proclaimed "I never want to see peace until the rebellion is completely crushed, unless it is turned into a war for the negro

${ }^{93}$ Edward R. Geary to Mother, October 13, 1863 in Brady, Hurrah for the Artillery, 299. 
and not for the Union." 94 In Virginia, slavery had not seemed so bad to Geary. The institution of slavery in Tennessee, by contrast, had so horrified him that he had switched from a position of wanting the abolitionists "driven out of this country" to comprehending that witnessing slavery could "make an abolitionist out of almost anyone." Geary's transformation, crucially, rested upon the local aspects of slavery and its setting in Tennessee, as much as anything else.

Geary's father, John White Geary, a War Democrat and former territorial governor of Kansas, had likewise been rather tempered in his comments about slavery while in Virginia. But when he reached Tennessee, the floodgates opened. After arriving in Tennessee, Brigadier General Geary told his wife that "It would be impossible for me to imagine just another country where such gross ignorance prevails among the people, and consequently such gross violations and want of propriety in conduct. They have not even houses in the country fit for pig-pens in the north." ${ }^{95}$ He later opined that "we are in a sort of out of the way place or backwoods where the sun of intelligence has never yet beamed, and where it has been the pleasure of the Southern Aristocracy to obscure the mental vision of the people in every possible manner." ${ }^{96}$ In Alabama, he complained of the "lazy, good for nothing white-trash" who lived in "miserable excuses for houses, usually consisting of two pens and shed connecting them." 97 The Georgian mansions of

\footnotetext{
${ }^{94}$ Edward R. Geary to Mother, October 11, 1862 in Brady, Hurrah for the Artillery, 169.

95 John White Geary to Mary, November 10, 1863 in A Politician Goes to War: The Civil War Letters of John White Geary, edited by William Allan Blair, with selection and introduction by Bell Irvin Wiley (University Park: Pennsylvania State University Press, 1995), 136.

96 John White Geary to Mary, December 20, 1863 in Blair, A Politician Goes to War, 149.

${ }^{97}$ John White Geary to Mary, May 1, 1864 in Blair, A Politician Goes to War, 168.
} 
Virginia had given way to the crude dog-trots of the Deep South. Geary offered a summation of his time in the West when he wandered around the outskirts of Atlanta after its fall to the Union in 1864. He noted that "northern fruits grow well here... and could be produced in abundance if the energy of white men was bestowed upon their production and culture." The white lassitude extended to "domestic cattle" which "are very scarce and of poor quality." He concluded that "in fine, the country has been cruelly 'niggered.'"98

Pennsylvania and New Jersey troops who remained in the East demonstrated far less overt prejudice toward African Americans. Several reasons account for this fact. First, Pennsylvania and New Jersey both lay close to the more established regions of the South, including Delaware, Maryland, and Virginia. In all of these states slavery had been long established and seemed in decline by the start of the Civil War. Troops from Pennsylvania and New Jersey had less fear that the slave South would colonize their states in the way that troops from Indiana, Iowa, and Illinois did. Their fears regarding slavery remained rooted in the political aspects of the Slave Power. Second, troops from Pennsylvania and New Jersey had encountered a landscape that seemed similar to their homes. The beauty of the Shenandoah Valley and northern Virginia sparked little reflection on how different the North and the South were, and thus less of an impetus to blame the institution of slavery, or the Slave Power, for the divergences between the two. Third, concentrations of African Americans, enslaved or free, in the East remained far lower than those in the Mississippi Valley. Troops in the East could easily integrate

\footnotetext{
${ }^{98}$ John White Geary to Mary, October 1, 1864 in Blair, A Politician Goes to War, 217.
} 
African American labor into the armies, with little concern that they would be swamped by them..$^{99}$

Fears that emancipation would overthrow the white social order evoked less vitriol from troops in Pennsylvania and New Jersey. The reason for this rests upon the fact that almost from the start of the war, the Army of the Potomac incorporated African American labor. Enslaved and free blacks pervaded camps throughout the entirety of the war, taking care of camp duties such as cleaning, cooking, and washing. In addition,

${ }^{99}$ Although Virginia was the most populous slave state and was home to the largest number of enslaved African Americans at the start of the Civil War, the areas that Union troops occupied at the start of the war in Northern Virginia and the Shenandoah Valley contained smaller concentrations of enslaved laborers than Southside Virginia and the Peninsula. As historian William J. Freehling has noted, different slave labor systems could exist within the same Southern state, exerting a powerful influence on both internal and external politics. Agriculture in these northern parts of Virginia focused on grain production, leading to a more dispersed labor force and smaller numbers of African Americans on any particular plantation. In Virginia, the "black belt," the area with the greatest concentrations of enslaved workers, stretched from the Peninsula across the state to counties south of the Appomattox River, where tobacco plantation used thousands of enslaved workers. By the time the Army of the Potomac moved to the Peninsula in early 1862, the enslaved population there had been greatly diminished. Both the Confederate government and the government of Virginia had impressed many of the enslaved male workers there; planters also had sufficient time to "refugee" large numbers of their more productive workers out of the area. See William W. Freehling, The Road to Disunion: Volume I: Secessionists at Bay, 1776-1854 (New York: Oxford University Press, 1990); William W. Freehling, The Road to Disunion: Volume II: Secessionists Triumphant, 1854-1861 (New York: Oxford University Press, 2007); Irvin L. Jordan, Black Confederates and Afro-Yankees in Civil War Virginia (Charlottesville: University Press of Virginia, 1995); and William A. Link, Roots of Secession: Slavery and Politics in Antebellum Virginia (Chapel Hill: University of North Carolina Press, 2003). 
numbers of African Americans assisted the army in support capacities such as teamsters, stevedores, and longshoremen. In 1862, for instance, Edward Acton noted that at Harrison's Landing, "the teamsters are all, or nearly all black--contrabands of course--and there are hundreds of them." ${ }^{100}$ While Pennsylvania and New Jersey troops still displayed racial prejudice, their familiarity and contact with African Americans on a daily basis helped habituate them to the end of slavery. That most blacks in the eastern armies worked for low wages and in menial capacities seemed to provide soldiers with a template for how emancipation would not threaten the extant social order after the war; the former enslaved would continue much as they had before the war, albeit for lower wages, without threatening cataclysmic competition with white labor. In short, Pennsylvania and New Jersey troops, from the start of the war, managed to integrate and domesticate African American labor within their camps and regiments.

Soldiers began engaging blacks early in the war to take care of domestic duties, particularly those jobs that women had done at home, such as cooking and washing. Soldiers remained ill-equipped to do such tasks, and found it easier to hire African Americans. Private Seth Waid III of the 83rd Pennsylvania Infantry Regiment remarked that "there are lots of colored women about the camp trying to get a chance to wash for the men." His squad also "got a cook. he is a mulatto. and he cooked our dinner today."101 Corporal James Porter Stewart of Knap's Independent Battery E, Pennsylvania Light Artillery observed that "the slaves are poreing in from all parts to get their freedom. We

\footnotetext{
${ }^{100}$ Edward A. Acton to Mollie, June 15, 1862 in Hammond, "'Dear Mollie'," 17.

${ }^{101}$ Seth Waid III diary entry, September 23, 1861 in The Civil War Diaries of Seth Waid III, edited by Robert Illisevich and Jonathan Helmreich (Meadville, PA: Crawford County Historical Society, 1993), 22.
} 
have one cooking for our Gun Squad and there is about five altogether in the Battery." ${ }^{102}$ Aungier Dobbs of the 22nd Pennsylvania Cavalry informed his wife that "we have a Negro cook in our mess." ${ }^{103}$ Milton McJunkin of the 85th Pennsylvania Infantry Regiment noticed "the darkies all along the road" who were "glad to see the Yankees comeing." He reported that "they wont work a bit more [for their masters] they bake all their meal up in a hoecake to give to the soldiers but we always pay them big prices for all we get from them." ${ }^{104}$ Private Leo W. Faller of the 7th Pennsylvania Reserves (36th Pennsylvania) Infantry Regiment wrote of how "there are a good many [contrabands] in our Regiment, Big and little." ${ }^{105}$ Sergeant Major Francis Adams Donaldson of the 71 st Pennsylvania Infantry Regiment wrote of hiring a former house servant, whom he referred to as "a 'quality dark,'" to cook for him. ${ }^{106}$ Paying African Americans for labor had become institutionalized in the army.

While enlisted men pooled their resources to engage African American labor for their squads, or purchased food from African Americans along the roadside, officers, with more resources, often hired blacks as personal servants. Albert Heffley hired Moses

\footnotetext{
102 James Porter Stewart to Brother, March 23, 1862 in Brady, Hurrah for the Artillery, 92.

${ }^{103}$ Aungier Dobbs to Esther, May 19, 1863 in Haas, Dear Esther, 153.

${ }^{104}$ Milton E. McJunkin to Margaret McJunkin, May 14, 1862 in Palm, Sauers, and Schroeder, The Bloody 85 th, 36 .

${ }^{105}$ Leo W. Faller to Sister, June 2, 1862 in Dear Folks at Home: The Civil War Letters of Leo W. and John I. Faller with an Account of Andersonville, edited by Milton E. Flower (Carlisle, PA: Cumberland County Historical Society and Hamilton Library Association, 1963), 70-71.

${ }^{106}$ Francis Adams Donaldson to Brother, March 15, 1862 in Inside the Army of the Potomac: The Civil War Experience of Captain Francis Adams Donaldson, edited by J. Gregory Acken (Mechanicsburg, PA: Stackpole Books, 1998), 49.
} 
as servant. Heffley thought him "a fine boy" who "attends to his business well." He noted: "When on a march he carries my gun \& woolen blankets, coffee pot \&c. He carries all the water, does the cooking--washing \& a great many other little things which makes him quite serviceable." ${ }^{107}$ Moses evidently did a good job, as Heffley noted in his diary "an elegant supper...consisting of dodgers, Potatoes onions coffee \& Hard tack" that the servant had prepared. ${ }^{108}$ Oliver Willcox Norton told his sister of how "Contrabands are pouring in on us every day. Almost every officer has one or two along now." ${ }^{109}$ He also noticed that "Our camps are full of niggers. They are rapidly taking the place of white men as teamsters. They seem well adapted to that." ${ }^{110}$ He later added that the "animals with the ears seem to understand the animals with the gum and ivory."111 Robert McAllister remarked on how "the blacks are actually in want of something to live on. They are glad to do our washing."112 Levi Bird Duff remarked that "On Christmas I went to the house of a negro woman, near here to get some washing done." ${ }^{113} \mathrm{He}$ also hired a personal servant named Melton, who stayed with him for the duration of the

\footnotetext{
${ }^{107}$ Albert Heffley diary entry, November 16, 1862 in Civil War Diaries of Capt. Albert Heffley and Lt. Cyrus P. Heffley, 13.

${ }^{108}$ Albert Heffley diary entry, January 3, 1863 in War Diaries of Capt. Albert Heffley and Lt. Cyrus P. Heffley, 13.

${ }^{109}$ Oliver Willcox Norton to Sister L., May 23, 1862 in Norton, Army Letters 1861-1865, 79.

${ }^{110}$ Oliver Willcox Norton to Sister L., June 10, 1862 in Norton, Army Letters 1861-1865, 88.

${ }^{111}$ Oliver Willcox Norton to Sister L., November 9, 1864 in Norton, Army Letters 1861-1865, 240.

${ }^{112}$ Robert McAllister to Ellen, August 9, 1861 in Robertson, The Civil War Letters of General Robert McAllister, 61.

${ }^{113}$ Levi Bird Duff to [Wife], December 27, 1861 in Helmreich, To Petersburg with the Army of the Potomac, 34 .
} 
war. ${ }^{114}$ A. F. Hill noted that early in the war his men had hired three African Americans to stay with them a cook. Initially, they hired Goens, Fairfax, and Robert Daffy; later on Mose and Pete joined them. Francis Adams Donaldson noted that in early 1862 "Our camp is filled with 'contrabands' and now everyone has his 'George' to pull off his boots and to wait upon him."115

Using these admittedly impressionistic data, a rough estimate of the number of African American camp followers can be ventured. At the outset of the war, a single Union regiment possessed a paper strength of about 1,000 men. A captain and two lieutenants served as officers for each of the ten companies; a colonel, lieutenant colonel, and major served as the regimental staff. If half of the officers in the regiment hired just one African-American servant, that would mean sixteen African American servants for the officers alone. If every twenty of the men in each company engaged a servant by pooling their resources, there would be five additional African Americans per company with the army. Thus, each regiment might have along with it around 65 African American servants. These figures are a bit conservative, as Stewart had noted that in the artillery battery, there were five African Americans for every 75 soldiers; Oliver Willcox Norton noted that many officers had more than one black servant along with them. With these figures, derived from lower estimates based on the testimony of soldiers, for every 1,000 white men in the Army of the Potomac there would be 65 African Americans who followed the army on a permanent basis, as opposed to a labor pool that would circulate

\footnotetext{
${ }^{114}$ Levi Bird Duff to [Wife], September 5, 1863 in Helmreich, To Petersburg with the Army of the Potomac, 140.

${ }^{115}$ Francis Adams Donaldson to Jacob, March 20, 1862 in Acken, Inside the Army of the Potomac, 51.
} 
in and out of the camps, selling hoecakes, doing laundry every now and again, and so forth. If accurate, these figures mean that at the start of the war, at a bare minimum, about $6.5 \%$ of the people in the camps of the Army of the Potomac would be African American. Undoubtedly, these numbers diminished as the Union regiments fell precipitously in size due to illness and combat casualties. Active campaigning would also have reduced the number of African American camp followers, but it remains that substantial numbers of African Americans worked within the camps of the Army of the Potomac. Among the camps in the East, African American labor had been domesticated within the Army of the Potomac with little problem from the start of the war.

Beyond the African Americans engaged in work around camp or with the army, a steady stream of refugees passed through the camps in a more transitory manner. Many escaped slaves made the journey to freedom and found audiences at regimental or army headquarters in order to provide military intelligence. During the 1862 Peninsula campaign, a constant procession made its way to the headquarters of Major General George B. McClellan, providing information on Confederate movements and strengths. ${ }^{116}$ While of little military value--accurately estimating enemy numbers required special training and familiarity with army organization--the stream of African Americans who passed through the camps habituated soldiers to their presence. Even when not working for the army, African Americans hovered around the fringes of the camps. As Private Thomas W. Smith of the 6th Pennsylvania Cavalry Regiment (Rush's Lancers) noticed,

\footnotetext{
${ }^{116}$ Russel H. Beatie, Army of the Potomac: Volume III: McClellan's First Campaign, March 1862-May 1862 (New York: Savas Beatie, 2007).
} 
"when evere we Leave a Camp the Niggers pick up all the old cloathing and Every thing that is left behind."117

Furthermore, the enslaved African Americans who sought freedom with the Army of the Potomac often made the army itself a way station on their way toward more permanent lodgings. These refugees often arrived in small groups, numbering from the sole African American to the tens, sometimes approaching hundreds. These numbers were far lower than those encountered in the West, where the larger concentrations of enslaved African Americans on cotton and sugar plantations led to huge numbers of escapees coming in to Union lines at one time. In the West, it was not unusual for parties numbering in the thousands to arrive at once. Harris Beecher of the 114th New York Infantry Regiment, for instance, reported a nine-mile long column of contrabands which he estimated included 8,000 escaping slaves. ${ }^{118}$ In the West, these huge parties of contrabands frightened the white soldiers, who saw their massive numbers as a direct threat to their livelihoods at home in Indiana, Illinois, or Iowa. Pennsylvania and New Jersey troops, rather than encountering vast numbers of blacks at one time, encountered parties in the dozens. Moreover, except for the blacks absorbed into the army as workers, African Americans passed on to concentrate at other locations outside of immediate proximity to the army. They moved on to the southeastern parts of Virginia to congregate in Hampton, Fort Monroe, and Suffolk. In the northern parts of the state they settled

\footnotetext{
${ }^{117}$ Thomas W. Smith to Brother, September 11, 1862 in "We Have It Damn Hard Out Here": The Civil War Letters of Sergeant Thomas W. Smith, 6th Pennsylvania Cavalry, edited by Eric J. Wittenberg (Kent, OH: Kent State University Press, 1999), 60.

${ }^{118}$ Harris H. Beecher, Record of the 114th Regiment, N.Y.S.V. Where It Went, What It Saw, and What It Did (Norwich: J. F. Hubbard, Jr., 1866),185.
} 
around Alexandria, Arlington, and Washington D.C. Surgeon William Watson of the 105th Pennsylvania Infantry Regiment found himself taken aback at their numbers in D.C., exclaiming "I never saw so many niggers in all my life as are here. You see contrabands of all sizes, ages and colors walking the streets constantly."119

Within this context, troops from Pennsylvania and New Jersey embraced emancipation and the enlistment of African Americans as soldiers as a wartime necessity. The long experience with African American work in camp, as well as the desire to shatter the Slave Power, led these soldiers from the Mid-Atlantic to support emancipation as a way to preserve the Union. The comments of Jacob W. Greenawalt demonstrated how African American labor within the Army of the Potomac led some troops to advocate emancipation. Greenwalt had noticed that "Thousands of Negroes are working on forts \& trenches here instead of our fatigued \& broken down soldiers." Such a practice dealt "death blows to our enemies. If their slaves escape, who will grow their grain \& provisions? Not the whites, for all that are able bodied are in the army. They will then be compelled to leave some at home to cultivate the land \& raise the means of subsistence." Greenawalt called for the Union to "adopt every means of weakening their resources." Thus, on a pragmatic basis, the Union should move toward emancipation as a means to weaken the Confederacy. Greenawalt thought that "these slaves need not be any encumbrance to us after we are done with them. We can pay them $\&$ send them back to Africa." He realized that "these views would not meet with the approbation of some," but he argued that "I feel assured that if some were to spend a Summer season campaigning

\footnotetext{
${ }^{119}$ Letter, September 18, 1862 in Letters of a Civil War Surgeon, edited by Paul Fatout (West Lafayette, IN: Purdue University Press, 1996), 13.
} 
here in this sickly locality they would be ready to give up fastidious notions \& resort to expedients." 120

Other soldiers expressed ideas similar to Greenawalt's. Aungier Dobbs believed that "some will change their notion about Negroes working and taken contrabands and rather than some of them would be willing to arm them a thing I was never in favor of but things is a working for the best and God will have things his own way have patience for all things will work for the best." ${ }^{121}$ Sergeant David Nichol of Knap's Independent Battery E, Pennsylvania Light Artillery, informed his family that "I read the President's Proclimation \& think that it is striking at the root of the evil, nothing will end this war sooner. I am no Nigger worshipper, but it has become a military necessity." ${ }^{122}$ Private John Strathern of the 8th Pennsylvania Reserves (37th Pennsylvania) Infantry Regiment commented that "I am glad to see the President has concluded to emancipate the slaves. This is what I call getting at the root of the matter. It is power that they are fighting for, and this what has given them power in times past. It is slave labor that feeds their Army. He tills the soil, while his master is off fighting for Jeff." ${ }^{123}$ Andrew Jackson Hartsock thought that "Slavery caused this trouble and in my estimation should perish, so that peace as lasting as country might be established." ${ }^{124}$ Private James T. Miller of the 111th Pennsylvania Infantry Regiment hoped that "old Abes emancipation proclamation will

\footnotetext{
${ }^{120}$ Jacob W. Greenawalt to Wife, August 4, 1862 in Hogan, Dear Jacob, 77-78.

${ }^{121}$ Aungier Dobbs to Esther, July 17, 1862 in Haas, Dear Esther, 96.

${ }^{122}$ David Nichol to Father and Home, January 4, 1863 in Brady, Hurrah for the Artillery, 190-91.

${ }^{123}$ John Strathern to Father, October 5, 1862 in Bumbera, The Civil War Letters of Cpl. John H. Strathern, 86.

${ }^{124}$ Andrew J. Hartsock diary entry, March 28, 1863 in Duram and Duram, Soldier of the Cross, 84.
} 
have a universal success for as far as I can see there is no other cause for this war but Slavery and the sooner it is done the better for us." ${ }^{125} \mathrm{He}$ supported the enlistment of African Americans into the army, telling his sister and brother that "the more nigers they get the better I will be suited for I would rather see a nigers head blowed of than a white mans." ${ }^{126}$ Lieutenant J. A. H. Foster of the 155th Pennsylvania Infantry Regiment remarked that "the rebellion must be put down, and to put the rebellion down, slavery must be put down with it." He explained that "You know when a person gets sick there usually is some cause for it, and just as soon as the cause is removed, the person generally gets well. So with this rebellion, if we can remove the cause of it, we certainly can perform a cure." ${ }^{127}$ While not egalitarian, these soldiers embraced emancipation and the enlistment of African Americans.

Troops from the Mid-Atlantic thought of the Slave Power conspiracy far differently than their western counterparts. Some men in the West saw the slave system as an existential threat and supported the end of slavery as the best means to destroy the Slave Power, which presented a direct threat to their livelihoods. Troops in the East saw less of a direct threat to their livelihood from the Slave Power, instead interpreting it as the end of the Constitution, the law, and Union. Believing themselves the true inheritors

\footnotetext{
${ }^{125}$ James T. Miller to Sister, February 6, 1863 in Bound to Be a Soldier: The Letters of Private James T. Miller, 111th Pennsylvania Infantry, 1861-1864, edited by Jedediah Mannis and Galen R. Wilson (Knoxville: University of Tennessee Press, 2001), 52.

${ }^{126}$ James T. Miller to Sister and Brother, April 25, 1864 in Mannis and Wilson, Bound to Be a Soldier, 135.

${ }^{127}$ J. A. H. Foster to George A. Gurley, April 12, 1863 in Linda Foster Arden, Letters from the Storm: The Intimate Civil War Letters of Lt. J. A. H. Foster, 155th Pennsylvania Volunteers, edited by Walter L. Powell (Chicora, PA: Mechling Bookbindery, 2010), 100.
} 
of the spirit of '76 and George Washington, they connected themselves to their Revolutionary heritage through constant and repeated pilgrimages to sites associated with that earlier war. The connection to physical settings, including the landscape, restrained soldiers from conceiving of the Civil War as a new revolution to bring liberty to African Americans through Emancipation. Pennsylvania and New Jersey walked in the footsteps, quite often literally, of their forefathers from the American Revolution. They struck at slavery because it had enabled the growth of a domestic aristocracy; their experiences in Virginia convinced them that the measure would not result in any radical restructuring of the country.

The ways in which some troops from the Mid-Atlantic interpreted the Civil War, and the end of slavery, owed much to their regional origin. They used the aspects of the Slave Power conspiracy thesis that fit well with their particular and personal connection to the Revolution. They reenacted the struggle of the patriots against aristocracy, with the slaveholding oligarchy standing in for the British crown. Their version of the Slave Power conspiracy thesis saw the Civil War in terms of a struggle against resurgent aristocracy. Western troops, however, without the same connection to the Revolution-either from their home states or the battlefields they visited--used different aspects of the Slave Power conspiracy thesis. Their struggle was one against an aristocracy that aimed to undermine their masculinity and degrade them in the same manner as the poor whites. 


\section{Chapter 2 \\ "The Bone and Sinue of the Population": Western Soldiers, Masculinity, and the Fight Against the Slave Power \\ $* * * * * * * * * * * * * * * * * * * *$}

Some western troops--from Illinois, Iowa, Indiana, Michigan, Minnesota, and Wisconsin--saw the Civil War as a struggle between the Union and the Slave Power, but their interpretations of the conspiracy were refracted through the lens of their particular conception of masculinity. The regional culture of these westerners led them to see the conflict quite differently than the troops from Pennsylvania and New Jersey, who largely refracted the war through the lens of the American Revolution. Many westerners believed themselves to be the measure of men, wresting crops from the fields and expanding commerce. An egalitarian impulse underlay their actions; men should advance in the world based on their abilities to produce. Many westerners perceived the Slave Power as an imperial force that sought to aggrandize the southern oligarchs even further at their expense. They also saw slaveholders as less than men, for the slaveholder profited from others without working. The concern that some men advanced through special pleading, putting on "style," or otherwise avoiding work and duty led some westerners to despise eastern troops, who they saw as shirkers whose selfishness aided the Slave Power. Their views of masculinity and the imperial threat of the Slave Power pushed them to embrace emancipation as the best way to strike down the Confederacy at the same time it intensified their antebellum racist anxieties. Furthermore, the protestations of the cowardly Copperheads against emancipation gained little traction among these soldiers, as the failure of the Democrats at home to act as men undermined their message. The 
rough-and-tumble masculinity of men in the West merged with the Slave Power thesis to lead thoroughgoing racists with a deep-seated hatred of African Americans to embrace emancipation.

As Peter N. Stearns has noted, "Manhood--the concepts and behavior associated with being a man--is of fundamental importance to understanding modern life." ${ }^{1}$ Scholars studying the Civil War have long examined the role of masculinity in shaping Southern and Confederate ideology. Betram Wyatt-Brown, for instance, has written extensively of how concepts of honor shaped the behavior of Southern men, leading them to react aggressively and violently towards perceived slights and imprecations. Historian Bertram Wyatt-Brown, in Southern Honor, has charted the paths in which southern masculinity, with its preoccupation with honor, diverged from the Northwest, and has also pointed out that honor as an organizing principle of masculinity extended throughout the United States. ${ }^{2}$ Some historians have looked at the emergence of a white-collar middle-class

${ }^{1}$ Peter N. Stearns, Be a Man! Males in Modern Society, 2nd Edition (New York: Holmes and Miller, 1990), 3.

${ }^{2}$ Stephen Berry has expanded upon Wyatt-Brown's analysis of honor in All That Makes a Man. Berry argued that the crucial difference between northern masculinity and Southern masculinity lay in how the two societies approached a civilizing mission. Northerners "were encouraged to pattern themselves after what might be called civilized manhood. Men were supposed to exemplify and embody the effects of civilization, underscoring their self-possession and self-restraint by holding up to the world a paragon of gentlemanly conduct, abstemious habits, and Christian rectitude." On the other hand, the southern men "were obliged not merely to effect Civilization but cause it." While Berry overstated the degree to which northern masculinity depended upon what would become white-collar values, his analysis points to the ways in which masculinities, North and South, might share some aspects. Reid Mitchell has also noted the importance of honor to soldiers, both North and South. Stephen W. Berry II, All That Makes a Man: Love 
sensibility, and thus a male identity predicated upon gentility, restraint, and moderation, one should be cautious in extending this paradigm to all northern men. ${ }^{3}$ Indeed, as

and Ambition in the Civil War South (New York: Oxford University Press, 2003), 34; Bertram WyattBrown, Southern Honor: Ethics and Behavior in the Old South (New York: Oxford University Press, 1982); and Reid Mitchell, Civil War Soldiers (New York: Viking, 1988), 16-17.

${ }^{3}$ Scholars tend to extrapolate from the experience of the Northeast and proclaim that all American men subscribed to the same set of values. Brian Luskey has charted the ways in which clerks in antebellum America came to terms with their occupations and how many other Americans found them to be "insufficient producers, citizens, and men" because they only handled other goods rather than producing them themselves. Mary P. Ryan has investigated similar transformations in Oneida and Utica, New York, as white-collar trades gained respectability during the economic shift from agricultural production to industrial revolution. Nina Silber has argued that "the readiness with which Union soldiers separated their commitment to the home from, and subordinated it to, their obligation to the nation revealed the distinctive ideological framework of the antebellum North and the unique socioeconomic world that had been created by the early nineteenth century's market and industrial revolutions." She explained that "the dramatic economic changes that affected the antebellum Northeast, although they did not signal the emergence of a fully industrialized economy, did mean that a higher premium was placed on income and wealth derived from profitable, as opposed to subsistence-oriented, enterprises." While her analysis is perhaps over generalized, Silber did make the salient point that the northern man, whatever his occupation, claimed his masculinity "less on the patriarchal claim of the father...and more on his ability to earn an income that would support his family in the present." Michael Thomas Smith, in an analysis of President Abraham Lincoln, has found that "two contrasting, contested ideals of aggressive masculinity and prototypically Victorian manliness as self-restraint coexisted throughout the Civil War era, and both played vital roles in the nation's political culture." As Richard Stott has pointed out in his analysis of the masculine subculture that he calls "jolly fellows," or men devoted to raucous good times and fighting, middle class values had not become universal at the time of the Civil War. Over the latter half of the nineteenth century, this subculture came under attack as being too disruptive. Middle-class urban values of restraint and propriety 
Stearns has written, the industrial revolution led to a redefinition of masculinity from the male as virile farmer, who wrested wealth from the ground, to "the male as aggressive business competitor... and the male as master of rational knowledge. ${ }^{4}$ At the time of the Civil War, however, Stearns's industrial "male as the master of rational knowledge" existed largely in the urbanizing and industrializing Northeast. In the West, the earlier virile farmer persisted. The ascendancy of white-collar professionals, such as clerks, lawyers, bureaucrats, and doctors, as the measure of a man emerged after the Civil War. Thus, while scholars have defined masculinity for middle-class northeasterners, urban workers, and southerners, they have neglected how westerners defined masculinity, and the ways in which western masculinity shaped their interpretation of the Civil War. Such a trend dissolves when a broad approach is taken, and it underscores the importance of looking at soldiers from the same region.

squeezed the jolly fellow out of favor, although Stott found remnants in popular visual culture, such as comic books. Crucially, Stott places the final victory of the white-collar or middle-class norms at the very tail end of the nineteenth century. Brian P. Luskey, On the Make: Clerks and the Quest for Capital in Nineteenth-Century America (New York: New York University Press, 2010), 18; Mary P. Ryan, Cradle of the Middle Class: The Family in Oneida County, New York, 1790-1865 (New York: Cambridge University Press, 1981); Nina Silber, Gender and the Sectional Conflict (Chapel Hill: University of North Carolina Press, 2008), 22-23; Michael Thomas Smith, "Abraham Lincoln, Manhood, and Nineteenth-Century American Political Culture," in This Distracted and Anarchical People: New Answers for Old Questions About the Civil War-Era North, edited by Andrew L. Slap and Michael Thomas Smith (New York: Fordham University Press, 2013), 41; and Richard Stott, Jolly Fellows: Male Milieus in NineteenthCentury America (Baltimore: The Johns Hopkins University Press, 2009).

${ }^{4}$ Stearns, Be a Man!, 49. 
E. Anthony Rotundo has observed that in the nineteenth century, "new manhood emerged as a part of a broader series of changes: the birth of republican government, the spread of a market economy, the concomitant growth of the middle class itself...The man's work role, not his place at the head of the household, formed the essence of his identity." By the mid-nineteenth century, a man's work had come to define him; "in a social sense, he was what he achieved." On the western edge of the United States, the most common form of work was freehold farming; while white collar occupations had made some inroads in the burgeoning urban and industrial areas, most work remained tied to the farm. Emerging middle-class work had yet to become the standard of Victorian masculinity, and manhood was instead still defined in older, agrarian terms. ${ }^{5}$

In the West, this older vision of American masculinity--marked by combat with Indians and the struggle to wrest subsistence and surplus from the earth--overrode the earlier settler culture of the region, that of the French. In popular culture, the French settlers who had spread across the Great Lakes region presented a cautionary example. The weak French had lived among the Indians, traded with them, and degraded themselves through intermarriage. Rather than taming the West, in the Anglo-American settler tradition, the French had been corrupted by it. Edward Watts has noted the power of these contrasting images in antebellum America: "The French colonies failed...because they did not subjugate the nonwhite indigenes, did not exploit natural resources, and did not constantly pursue growth and ambition. On the other hand, the Anglos removed the Indians, commercialized their fertile soil, and always sought open

\footnotetext{
${ }^{5}$ E. Anthony Rotundo, American Manhood: Transformations in Masculinity from the Revolution to the Modern Era (New York: Basic Books, 1993), 3, 69.
} 
lands to own and call their own." For some westerners, Gallic failures threw into sharp relief their own successes. In fact, the contrast proved to them their own potential, as the cutting edge of republican expansion in the world, "to supersede European imperial aspiration through [their own] inspired mixture of democratic energy, capitalist ambition, and sense of [their own] mission." In this fashion, western ideals of the tie between masculinity and work had a negative image that it defined itself against; the French predecessors, rather than carving a living from the land, had traded and cavorted with the Native Americans. Instead of creating a productive empire in the West, they had been swept aside by the robust American republic. ${ }^{6}$

With the negative French example in mind, the preoccupation of many westerners with labor becomes clearer. The political calculus of western states often rested more on shared interests than constant partisan conflict. In other words, the Republican and Democratic parties frequently advanced similar policy platforms in these states. Jonathan A. Glickstein, in an analysis of labor relations in the antebellum United States, has found that "Distinctive concerns and anxieties over declining economic opportunity impelled many early nineteenth-century skilled laborers to share with elite commentators certain perceptions of the unskilled, dependent, and 'undeserving' poor." Thus, "to the extent that they did so, craftworkers lent support to the period's formative free-labor, free-market ideology." These links, related to a belief in free labor and the threat posed by slavery, extended across party lines. Glickstein noted that even Democrats possessed "a genuine faith in: (1) the capacity of free labor to exclude and otherwise completely prevail over

\footnotetext{
${ }^{6}$ Edward Watts, In This Remote Country: French Colonial Culture in the Anglo-American Imagination, 1760-1860 (Chapel Hill: University of North Carolina Press, 2006), 3-4.
} 
slave labor in the existing territories without the assistance of a congressional ban; and (2) the capacity of free farmers and wage-earners to coexist in any case in proximity to slaveowners and their bondsmen without being corrupted and enfeebled." So, while the antebellum status quo persisted, Democratic westerners embraced free labor ideals, though without as much anxiety as Republicans for the corrupting influences of slavery. The Civil War changed all of that, as the Slave Power unmasked itself through secession. And opposition to the Slave Power fit with antebellum Democratic hostility towards "business and professional elites" as that party tended "to envision an inevitable conflict between these and the nation's virtuous workers." ${ }^{7}$ Hubert H. Wubben has noted that in Iowa, settlers of all political persuasions wanted "homestead laws, internal improvements, and railroad land grants." ${ }^{8}$ Thus, while the Republican Party is usually identified with Free Labor ideals, infrastructure expansion, and improvements, Democrats also espoused these goals. Westerners of all political stripes could believe in similar core ideals regarding farmers and free labor, a stance that owed much to their definition of hardy manhood. ${ }^{9}$

The question of African American slavery, as some westerners viewed it, exemplified the intersection of politics and masculinity. In western states, both

\footnotetext{
${ }^{7}$ Jonathan A. Glickstein, American Exceptionalism, American Anxiety: Wages, Competition, and Degraded Labor in the Antebellum United States (Charlottesville: University of Virginia Press, 2002), 96, 159, 212.

${ }^{8}$ Hubert W. Hubben, Civil War Iowa and the Copperhead Movement (Ames: Iowa State University Press, 1980), 4.

${ }^{9}$ The best discussion of the Republican Party in the antebellum era is Eric Foner, Free Soil, Free Labor, and Free Men: The Ideology of the Republican Party Before the Civil War (reprint; New York: Oxford University Press, 1995 [1970]).
} 
Democrats and Republicans could agree on a dislike of African Americans. As V. Jacque Voegeli has pointed out, "the Middle West--Ohio, Indiana, Illinois, Iowa, Michigan, Wisconsin, and Minnesota--was the region most firmly committed to white supremacy." Many residents of those states thought "Negroes were biologically inferior persons to be shunned." According to Voegeli, "to most Midwesterners of all parties, experience and the teachings of science still seemed to point irresistibly toward the innate inferiority of the black race." ${ }^{10}$ The supposed inferiority of blacks threatened to degrade the white inhabitants of these state through contact; fears that African American labor would damage wages also struck at voters' masculinity. With most western states banning African American emigration, Republicans sought to reassure voters that they favored limiting the expansion of slavery, a policy that "would prevent the spread of the Negro westward."11

Thus, when westerners enlisted in the armies and marched South, they carried with them these antebellum ideas regarding masculinity and slavery. When they saw the South, these ideas led them to find the hand of the Slave Power conspiracy behind the Civil War. For many of them, their attitudes towards effete easterners, horror at Southern whites, and dislike of enslaved African Americans developed upon these earlier trajectories. So, while many westerners could embrace emancipation as a war aim, they found little that forced them to revise their earlier opinions.

\footnotetext{
${ }^{10}$ V. Jacque Voegeli, Free but Not Equal: The Midwest and the Negro During the Civil War (Chicago: University of Chicago Press, 1967), 1, 178.

${ }^{11}$ Eugene H. Berwanger, The Frontier Against Slavery: Western Anti-Negro Prejudice and the Slavery Extension Controversy (Urbana: University of Illinois Press, 1967), 130.
} 
Western conceptions of masculinity came into sharp relief when westerners discussed the performance of eastern armies. Western troops, accustomed to success against fumblingly incompetent Confederates as Gen. Braxton Bragg, Brig. Gen. Gideon J. Pillow, and Lt. Gen. Leonidas Polk, thought that the failures of the Army of the Potomac to bring Gen. Robert E. Lee's Army of Northern Virginia to bay stemmed from a lack of grit or élan. Many westerners pointed to what they perceived as the eastern preoccupation with ensuring appropriate uniforms and parade ground drill, rather than proper performance on the battlefield, as evidence of inferior masculinity. Frustration with the continuing lack of eastern success over the course of the war led some Western soldiers to detect nefarious motives among easterners; rather than standing and fighting like men, easterners sought to aggrandize themselves by protracting the war.

The failures of the Army of the Potomac provided Western soldiers with something to gripe about constantly. They compared their own victories in the West to what they saw as stagnation or reverse in the East, and they vented their anger in letters home or in their diaries. As Pvt. Allen Geer of the 20th Illinois Infantry Regiment mused in 1862, news of Lee's invasion of Maryland caused "general indignation among the Western troops. They impute it all to lack of soldierly courage in officers and men." ${ }^{12}$ In October 1863, Pvt. Charles Musser of the 29th Iowa Infantry Regiment lamented that despite the victory at Gettysburg, "it will yet take Some western men to clean out them eastern Confeds." ${ }^{13}$ Capt. Francis Moore of the 2nd Illinois Cavalry exclaimed, after the

\footnotetext{
${ }^{12}$ Diary Entry September 9, 1862 in The Civil War Diary of Allen Morgan Geer, Twentieth Regiment, Illinois Volunteers, edited by Mary Ann Andersen (Denver: Robert C. Appleman, 1977), 53.

${ }^{13}$ Charles O. Musser to Father, October 23, 1863 in Soldier Boy: The Civil War Letters of Charles O. Musser, 29th Iowa, edited by Barry Popchock (Iowa City: University of Iowa Press, 1995), 94.
} 
promotion of Maj. Gen. Ulysses S. Grant to lieutenant general and his transfer East, that "our western soldiers have unbounded confidence in Grant and believe that under his command, even the ditch-digging, winter-quartered Army of the Potomac may be productive of much good, and the boasted quiet of the valley of the Potomac will soon be broken by glad shouts of our victorious army." ${ }^{14}$ Besides revealing his foggy notion of eastern geography--thinking that the Potomac River cut through a vast watershed like the Mississippi River--Moore displayed typical western sentiments regarding the vigor of the Eastern troops. Unlike the western troops, the Army of the Potomac spent long stretches of the year in winter camp and preferred digging ditches to actually fighting. Capt. Charles W. Wills of the 103rd Illinois Infantry Regiment concurred, noting that "General feeling is that the Potomac Army is only good to draw greenbacks and occupy winter quarters." 15

Some western soldiers taunted eastern soldiers and officers who had the misfortune of encountering them. ${ }^{16}$ Charles W. Wills related a conflict his men engaged

\footnotetext{
${ }^{14}$ I have treated this memoir as a contemporary document. Moore relied heavily upon notes, letters, and diaries when composing his memoir. As is evident, the sentiments that appear in the memoir differ little from the writings of other soldiers cited here. It appears that Moore revised but little his observations when he assembled his earlier writings into this memoir; The Story of My Campaign: The Civil War Memoir of Francis T. Moore, Second Illinois Cavalry, edited by Thomas Bahde with a foreword by Michael Fellman (DeKalb: Northern Illinois University Press, 2011), 189.

${ }^{15}$ Letter, November 21, 1862 in Army Life of an Illinois Soldier: Including a Day-by-Day Record of Sherman's March to the Sea, compiled by Mary E. Kellogg with a foreword by John Y. Simon (reprint; Carbondale: Southern Illinois University Press, 1996 [1906]), 144.

${ }^{16}$ Scholars have tended to examine these encounters as evidence of class tensions between officers and enlisted men, but often incidents of disobedience centered immediately upon regional chauvinisms. Phillip
} 
in with Brig. Gen. William Harrow, who had recently arrived from the east. The men shouted at the general, as he passed, "Bring out your Potomac horse, 'Fall back on your straw and fresh butter,' 'Advance on Washington.'" Harrow, understandably upset at this breach of discipline, punished the men who had yelled at them by having them ride a wooden horse in front of his tent. The westerners, themselves upset at having been punished, tore down the punitive device and sent it to Maj. Gen. James B. McPherson, a

Cuccia, taking a narrow look at Maj. Gen. Nathaniel P. Banks's 1864 Red River Campaign, sought to determine if "there really was a difference between Easterners and Westerners, and if so, what role did it play in the campaign." He found that westerners and easterners thoroughly disliked each other, with eastern troops placing a premium on looking the part of the soldier while western soldiers placed more importance on combat experience. Cuccia determined that these tensions existed primarily on the surface, and that while "Banks's army was divided by regional animosities...the Easterners and Westerners put aside their differences in the face of a common enemy." Historian Lorien J. Foote has argued that tension between the eastern armies and the western armies stemmed from class conflict between officers and men and became more acute after conscription in 1863 and 1864. Similarly, historian Steven J. Ramold has looked at conflicts between western and eastern soldiers as an example of the loose discipline endemic in Civil War armies. Rather than displaying a fundamental difference between how westerners and easterners saw themselves, conflicts between the two groups revealed the tension between order-minded regular officers and rambunctious citizen soldiers. While these three historians made judicious assessments, it seems that neither the perennial regular soldier/volunteer soldier debate nor the existence of class conflict explains the degree to which westerners complained about easterners, nor the ways in which they did so. Phillip Cuccia, "'Gorillas' and White Glove Gents: Union Soldiers in the Red River Campaign," Louisiana History: The Journal of the Louisiana Historical Association, Vol. 36 No. 4 (Autumn 1995), 414; Lorien Foote, The Gentlemen and the Roughs: Violence, Honor, and Manhood in the Union Army (New York: New York University Press, 2010), 8, 120-28; and Steven J. Ramold, Baring the Iron Hand: Discipline in the Union Army (DeKalb: Northern Illinois University Press, 2010), 102-05. 
renowned hard fighter and therefore favorite of the westerners, "with a note tacked on it, telling him to furnish him plenty of straw and use him carefully, as he was Potomac stock and unused to hardships." ${ }^{17}$ As Wills' anecdote attests, some western troops saw the easterners as accustomed to unearned luxury; whereas Western troops experienced hardship, easterners enjoyed ample fodder and fresh butter. And, rather than advancing on Richmond, they showed their true mettle by advancing on Washington, which is, retreating in the face of the rebels. The westerner troops, not content simply to tear down the punitive sawhorse, played another prank when "a big box came to General Harrow with heavy express charges. An ambulance hauled it 20 miles before it caught up with him, and on opening it he found a lot of stones, a horse's tail, and a block of wood with a horse's face pinned on it labeled 'head and tail of your Potomac horse."'18

Ill-feeling between some westerners and some easterners extended beyond irritated soldiers taking out their frustrations on stuffy generals. Pvt. George Remley of the 22nd Iowa Infantry Regiment told his father how "the 19th Army Corps is composed mostly of eastern troops and the 13th Army Corps of western boys and between them there is not a great deal of good feeling." ${ }^{19}$ He later elaborated how "General Banks and the eastern troops generally are most cordially hated by a majority of the 13 th Army Corps." Remley gave several causes, but noted that the chief one arose from a perceived slight to the manhood of the westerners. He wrote that "when Banks review[ed] the 13th

\footnotetext{
${ }^{17}$ Letter, May 1, 1864 in Kellogg, Army Life of an Illinois Soldier, 231-32.

${ }^{18}$ Letter, May 26, 1864 in Kellogg, Army Life of an Illinois Soldier, 248.

${ }^{19}$ George Remley to James Remley, October 8, 1863 in Southern Sons, Northern Soldiers: The Civil War Letters of the Remley Brothers, 22nd Iowa Infantry, edited by Julie Holcomb, introduction by Steven A. Woodworth (DeKalb: Northern Illinois University Press, 2004), 95.
} 
Army Corps at New Orleans, he at first was inclined to reject them on account of their ragged and war-worn appearance." This stung deeply, as a do-nothing easterner placed appearance before fighting prowess, and accordingly the men of the 22 nd Iowa took it as "a deep insult to the veterans of Vicksburg." ${ }^{20}$ Sgt. William Henry Harrison Clayton of the 19th Iowa Infantry Regiment offered a similar assessment of the situation; while not as critical of Banks as Remley, he thought that "we did not put on as much style as the eastern troops do, but when anything is to be done, the western boys are the ones to do it." ${ }^{21}$ Capt. William Black of the 37th Illinois Infantry Regiment reflected upon rumors that western troops would be transferred East, and thought "it will be the leaven which will leaven the whole lump, and enable that army, which has heretofore disgraced American manhood, to accomplish something." 22

Perceptions that easterners received special consideration grated on some westerners. Col. Francis T. Sherman of the 88th Illinois Infantry Regiment called for "the men of the northwest" to "crush this hydra of the South" because he believed "the Grand Army of the Potomac, the pet of the Union, with its boasts of what it is going to do, is

\footnotetext{
${ }^{20}$ George Remley to Howard Remley, October 19, 1863 in Holcomb, Southern Sons, Northern Soldiers, 98.

${ }^{21}$ William H. H. Clayton to Parents, August 23, 1863 in A Damned Iowa Greyhound: The Letters of William Henry Harrison Clayton, edited by Donald C. Elder III (Iowa City: University of Iowa Press, 1998), 92.

${ }^{22}$ William Black to Mother and Sister, April 9, 1864 in Duty, Honor, and Country: The Civil War Experiences of Captain William P. Black, Thirty-Seventh Illinois Infantry, edited by Michael E. Banasik (Iowa City: Camp Pope Bookshop, 2006), 293.
} 
played out." 23 Implicitly, unlike the Army of the Potomac, the westerners, fighting men, delivered victories rather than boasting. Other soldiers felt similarly; Lt. Chesley A. Mosman of the 59th Illinois Infantry Regiment complained that his regiment had finally settled into camp, but had been called to assist Maj. Gen. Joseph Hooker's corps. Mosman, upset at having to leave comfortable lodgings, asked: "Can't those Potomac boys take care of themselves?" ${ }^{24}$ Some western troops firmly believed themselves superior to the eastern troops. Capt. Jacob Ritner of the 25th Iowa Infantry Regiment resented the pampered status of the Army of the Potomac. He sarcastically remarked: "I see that almost all the generals and other officers of the Potomac Army have gone home to spend the holidays. Well, poor fellows, I suppose they deserved it. They couldn't have fine dinners or other nice things sent to them! Then they have such a hard time, and done so much!" 25

When western troops travelled to Washington, D.C., for the Grand Review that followed the surrenders of Lee's and Gen. Joseph E. Johnston's Confederate armies, they encountered large numbers of eastern troops. They commented on the differences they saw. Allen Geer thought that "These Eastern men are stylish but will not compare with

\footnotetext{
${ }^{23}$ Francis T. Sherman to Father, [June] 1863 in Quest for a Star: The Civil War Letters and Diaries of Colonel Francis T. Sherman of the 88th Illinois, edited by C. Knight Aldrich (Knoxville: University of Tennessee Press, 1999), 45.

${ }^{24}$ Chesley A. Mosman diary entry, October 24, 1863 in The Rough Side of War: The Civil War Journal of Chesley A. Mosman, edited by Arnold Gates (Garden City, NY: Basin Publishing, 1987), 105.

${ }^{25}$ Jacob Ritner to Emeline Ritner, January 8, 1865 in Love and Valor: Intimate Civil War Letters Between Captain Jacob and Emeline Ritner, edited by Charles F. Larimer (Western Springs, IL: Sigourney Press,
} 2000), 105. 
our Western boys for true blue soldiers. ${ }^{26}$ Familiarity bred even more contempt with Geer; he noted: "our estimates of the Eastern Army's merits grow less daily. It has displayed neither the energy or determination of the Western Army." ${ }^{27}$ Pvt. Thomas J. Davis of the 18th Wisconsin Infantry Regiment laughed about how "the boys say we are now soldiering in Potomac-style." That meant that rather than fighting, the men would "soon draw paper collars, red neck ties, straw, and postage stamps and boot-blacking and having to do and get furloughs every six weeks." 28

Yet these animosities towards eastern troops revealed more than simple jealousy at furloughs and perceived coddling. ${ }^{29}$ Western troops thought that easterners concerned

\footnotetext{
${ }^{26}$ Diary entry, May 8, 1865 in Andersen, The Civil War Diary of Allen Morgan Geer, 219.

${ }^{27}$ Diary entry, May 12, 1865 in Andersen, The Civil War Diary of Allen Morgan Geer, 220-21.

${ }^{28}$ Thomas J. Davis to Wife, May 28, 1865 in The Badax Tigers: From Shiloh to the Surrender with the 18th Wisconsin Volunteers, edited by Thomas P. Nanzig (Lanham, MD: Rowman \& Littlefield, 2002), 324.

${ }^{29}$ A postwar history of the 27 th Indiana Infantry Regiment, a unit which served with the Army of the Potomac, noted the perception among westerners "that the Army of the Potomac was a 'paper-collar,' 'soft-
} bread,' 'feather-bed,' 'review and dress-parade' army and that it would not fight." Despite this, the men of the 27th "were convinced... of the rigorous character...of service in the Army of the Potomac." Service in the East had allowed them to see that "on top of the crucial test of all patriotic devotion and all soldierly virtues, put upon the men of the Eastern armies, by their numerous uncalled-for defeats, and their repeated buffetings and disappointments...the long sustained physical efforts they were required to make, the exposures they endured and the deprivations they suffered, as compared with others armies, are not well understood in some quarters, even to the present day. A Member of Company C [E. R. Brown], The Twenty-Seventh Indiana Volunteer Infantry in the War of the Rebellion 1861 to 1865 First Division 12th and 20th Corps: A History of Its Recruiting, Organization, Camp Life, Marches and Battles, Together with a Roster of the Men Composing It, and the Names of All Those Killed in Battle or Who Died of Disease, and As Far As Can Be Known, of Those Who Were Wounded ([Monticello, IN]: n.p., [1899]), 438. 
themselves with "style" rather than courage, and money rather than selfless service. When some western troops observed the gulf between officers and enlisted men in the eastern armies, they found themselves horrified. They resented the hierarchical practice and thought that it undermined the egalitarianism that led to good soldiering. With easterners, the western troops saw a mirror image of how they defined their masculinity. The stereotype of the grasping Yankee had put on shoddy Union blue: effete eastern soldiers concerned themselves with condescension, style, and profit and lost sight of battlefield performance. ${ }^{30}$ In short, easterners offended the westerners' sense of being a man.

\footnotetext{
${ }^{30}$ Western troops indeed kept an eye open for people they thought profited from the war at the expense of the war effort. Sgt. Maj. Charles H. Cox of the 70th Indiana Infantry Regiment complained about "such men as Jews, Sutlers, Sharks, \&c, who sell their articles at scandalous prices." Sgt. Thomas Wise Durham also wrote of "'The Wandering Jew' with his cheap 'pure gold' watches and jewelry" and how soldiers "would knock Mr. Jew down and give him a few kicks as personal satisfaction." Thus, Ulysses S. Grant's Order 11, banning Jews from Union lines, appears not so much as a departure from western sentiment against profiteers, but as an expression of it. Charles H. Cox to Sister, December 5, 1862 in "The Civil War Letters of Charles Harding Cox," edited by Loran Lutes Sylvester, Indiana Magazine of History Vol. 68 No. 1 (March 1972), 40; Three Years with Wallace's Zouaves The Civil War Memoirs of Thomas Wise Durham, edited by Jeffrey L. Patrick (Macon, GA: Mercer University Press, 2003), 55; Stephen V. Ash, "Civil War Exodus: The Jews and Grant's General Order No. 11," in Jews and the Civil War: A Reader, edited by Jonathan D. Sarna and Adam Mendelsohn (New York: New York University Press, 2010), 363 84; Gary L. Bunker and John J. Appel, "'Shoddy' Antisemitism and the Civil War," in Sarna and Mendelsohn, 311-34; John Simon, "The Obnoxious Order," in Sarna and Mendelsohn, 353-62; and Jonathan D. Sarna, When General Grant Expelled the Jews (New York: Nextbook, 2012).
} 
Westerners pointed towards "style" as a major problem. William H. H. Clayton wrote to his brother that "I had heard a great deal said about the superiority of western troops over eastern troops, but was disinclined to believe it, but I think that there is in fact a great difference." Clayton thought that the eastern troops' "officers do not associate with the men as ours do...they are also much more strict and put on a great deal of style." ${ }^{31}$ Cpl. George W. Squier of the 44th Indiana Infantry Regiment complained of the "Eastern pimp" soldiers and how "the Eastern troops put 'some stile'--are finer dressed and appear to think that they are 'some'," an attitude that provoked friction with many western troops. $^{32}$

Indeed, some westerners tended to see the poor performance of eastern troops as a product of the preoccupation with style and grasping self-advancement rather than patriotism. George Squier fulminated that "money is the order of the day. Little difference how it is made, wethe[r] it is defrauding the Government or the private soldier who leaves his family and friends...I can hardly feell like cursing this government, but the way the affairs of this nation is conducted--merit is not respected; a man's rights is not recognisced; men are dogs. Shoulder straps and money are Deities." ${ }^{33}$ Pvt. William H. Bradbury of the 129th Illinois Infantry Regiment opined on the failures of the Army of the Potomac, ascribing them to the profiteering of Eastern officers. He had "no doubt the

\footnotetext{
${ }^{31}$ William H. H. Clayton to Brother, August 27, 1864 in Elder, A Damned Iowa Greyhound, 118.

${ }^{32}$ George W. Squier to Ellen, October 10, 1863 in This Wilderness of War: The Civil War Letters of George W. Squier, Hoosier Volunteer, edited by Julian A. Doyle, John David Smith, and Richard M. McMurry (Knoxville: University of Tennessee Press, 1998), 72.

${ }^{33}$ George W. Squier to Ellen, November 6, 1862 in Doyle, Smith, and McMurry, This Wilderness of War, 20.
} 
privates are tired of the war. With officers, the case may be different as they are getting more now than most of them made before. ${ }^{34}$ Pvt. George Cram of the 105th Illinois Infantry Regiment moaned of how the "imbecility of our administration and the cowardice of our officers" prolonged the rebellion. ${ }^{35}$ Charles Musser worried "as long as there is so many Speculators at the head of the armys, there will be war. ${ }^{\prime 36}$ He later elaborated that "I came into the army for my country's good and not for money. there is too much of this 'Green Back' Patriotism in the army. this war has been prolonged by the influence of them miserable, low flung Villains wearing the Uniforms of American Army officers. if they were out of the way, this war would Soon end." ${ }^{37}$ Thomas J. Davis lamented that "among the upper circles of military authority, they seem to have made more disign in making big officers and killing privates than they have in putting down rebellion." 38

Sgt. Taylor Peirce of the 22nd Iowa Infantry Regiment wove all these strands together in his letters. He detested eastern soldiers, seeing them, and the officers in particular, as selfish men concerned with aggrandizement and style rather than selfless

\footnotetext{
${ }^{34}$ William H. Bradbury to [Mary Brown Bradbury], January 23, 1863 in While Father is Away: The Civil War Letters of William H. Bradbury, edited by Jennifer Cain Bohrnstedt and compiled by Kassandra R. Chaney (Lexington: University Press of Kentucky, 2003), 61.

${ }^{35}$ George Cram to Mother, January 1, 1863 in Soldiering with Sherman: The Civil War Letters of George F. Cram, edited by Jennifer Cain Bohrnstedt, introduction by Orville Vernon Burton (DeKalb: Northern Illinois University Press, 2000), 34.

${ }^{36}$ Charles O. Musser letter fragment, February 3, 1863 in Popchock, Soldier Boy, 25.

${ }^{37}$ Charles O. Musser to Father, January 17, 1864 in Popchock, Soldier Boy, 103.

38 Thomas J. Davis to Sister, February 17, 1863 in Nanzig, The Badax Tigers, 144.
} 
patriotism. While western troops displayed courage, subordinating style and hierarchy to egalitarianism devoted to crushing the Confederacy, eastern troops blundered about, prolonging the war for their interests. He explained to his wife how they "have not the sense of fight that our western boys have for the reason that the officers put on too much style and make underlings of the soldiers and break their spirits before they come in contact with the enemy and are then so degraded that they only fight from a sense of submission to orders of their officers and not from an innate sense of right and manhood." Peirce liked that "the principal of the western boys is such that the officers are not above us and we fight from inherent feelings of right and manhood. ${ }^{39} \mathrm{He}$ later mentioned that "the more I See of the milk and water troops from the east the more I dont like them," criticizing the fact that "many of the officers of the east are superannuated politicians and Editors or something of the kind." He hoped "to See such men Superseded by men who have sand in their gizzard to carry out the necessary plans to crush this Southern Oligarchy." ${ }^{40}$ Nathaniel Banks represented this class of man, for "like all the leaders of the republican party [he] is so d----d selfish that he does not care for the welfare of others. If he makes money and saves himself he does not care." ${ }^{41}$ Peirce echoed Squier, asserting of easterners that "Their officers are generally pimps and Saloon

\footnotetext{
${ }^{39}$ Taylor Peirce to Catharine, November 7, 1863 in Dear Catharine, Dear Taylor: The Civil War Letters of a Union Soldier and His Wife, edited by Richard L. Kiper (Lawrence: University Press of Kansas, 2002), 153.

${ }^{40}$ Taylor Peirce to Catharine, February 3, 1864 in Kiper, Dear Catharine, Dear Taylor, 181.

${ }^{41}$ Taylor Peirce to Catharine, May 11, 1864 in Kiper, Dear Catharine, Dear Taylor, 207.
} 
keepers who have had some little political influence and have obtained their commissions through this means and are the lowest of the low." ${ }^{42}$

Peirce told his wife that he had discovered "the reason why the army of the Potomac has been so inefficient or so much less successful than the western army." He explained that "the Army itself is made up of the most doless and worthless part of the Population and the officers are men of fine haired milk and water kind either out of some law office where they had been setting for two or three years trying to get hold of an Idea, or else some clerk from behind a dry goods counter whose only thought was to oil their mustache and show their silly selves to some sillier young lady." Peirce liked the western troops much better, as they "are drawn from the bone and sinue of the Population and the officers generally chosen for their ability are both able and willing to endure the fatigues and discomforts of camp life to win for themselves a name and for their country a victory." 43

The comparisons that some western troops made between themselves and easterners revealed much about their definitions of masculinity. They placed an emphasis on doing, as contrasted to the "style" that they thought easterners affected. They saw their own hale heartiness as farmers and workers on the frontier as superior to lawyers and clerks--white collar professions then emerging in the East and soon to become the new standard of male success. Such eastern professionals, in their eyes, were weak men of the "milk and water kind" who spent more time with paper collars and oiled mustaches than

\footnotetext{
${ }^{42}$ Taylor Peirce to Catharine, July 26, 1864 in Kiper, Dear Catharine, Dear Taylor, 242.

${ }^{43}$ Taylor Peirce to Catharine and All the Rest, August 7, 1864 in Kiper, Dear Catharine, Dear Taylor, 24748.
} 
in fighting Rebels. The western criticisms of the eastern men and officers also revealed that they took a deep and abiding dislike to anyone who profited without earning that gain, a feeling that also applied to the southern lords of the lash.

The sentiments towards easterners carried over to politicians at home. The war opened a gulf between the troops in the field--who saw themselves as doing their manly duty--and those who stayed behind. Men at home, rather than demonstrating courage, showed that they placed more value on profit and political advancement than on winning the war. Those at home in the West seemed cut from the same shoddy cloth as the easterners, preoccupied with money and style rather than saving the Union. And especially troubling were the Peace Democrats. ${ }^{44}$

${ }^{44}$ These political expressions of western soldiers - that they sought only the restoration of the Union and stood by their government - mirrored, and perhaps antedated, broader shifts in wartime politics during the Civil War. Adam I. P. Smith, in No Party Now, argued that the success of the Union war effort during the Civil War depended upon "the administration's exploitation of the antipartisan discourse of loyalty and dissent." The formation of the Union Party and a focus upon uniting to defend the Union mitigated harmful elements of the partisan political system. In short, "these developments provided a public space, that by claiming to be above partisanship and removed from the selfishness and corruption of politics, broadened the base of support for the war." As Smith has written more recently, "the persistence of the language of conservatism--even among those who supported the Lincoln administration--reminds us that slavery and the threat posed by the Slave Power were seen by many in the North as the sharp end of a more general crisis in which the core question was whether the Union, conceived as the guarantor of liberty, could survive." Western troops, despite professing that they were Democrats, could support the administration without renouncing their partisan identification. Indeed, scholar Jonathan W. White has found that contrary to many accounts, the war did not shift the identification of Union troops to that of the Republican Party. Western troops supported the restoration of the Union, and the pusillanimous Democratic politicians at 
Soldiers placed the preservation of the Union ahead of all else. Sgt. John Quincy Adams Campbell of the 5th Iowa Infantry Regiment expressed this stance when he explained his decision to enlist in the Union army. He professed that he had "volunteered to fight in this war for the Union and a government...not from any feeling of enthusiasm, nor incited by any hopes of honor [or] glory, but because I believe that duty to my country and my God assist me in crushing this wicked rebellion against our government, which rebellion men have instigated to secure their own promotion, to place honor(s), and to secure the extension of that blighting curse--slavery--o'er our fair land." ${ }^{45}$ Campbell placed himself, selflessly devoted to the "war for the Union" without hopes of "honor or glory," above the "rebellion men" who acted out of self-interest in order "to secure their own promotion." Capt. Joseph W. Young of the 97th Indiana Infantry Regiment expressed a similar sentiment, telling his wife that "I left my home and

home undermined their own message by failing to act as men. In sum, soldiers tended to see themselves as almost a separate party, one devoted to selfless service rather than political grasping, created through shared service in the field. This identification had been brought about by the exigencies of the war and existed only for its duration. Adam I. P. Smith, No Party Now: Politics in the Civil War North (New York: Oxford University Press, 2006), 160; Adam I. P. Smith, "Conservatism, Transformation, and the War for the Union," in Reconfiguring the Union: Civil War Transformations, edited by Iwan W. Morgan and Philip John Davies (New York: Palgrave Macmillan, 2013), 53; and Jonathan W. White, "'For My Part I Dont Care Who Is the Elected President': The Union Army and the Elections of 1864," in This Distracted and Anarchical People: New Answers for Old Questions About the Civil War-Era North, edited by Andrew L. Slap and Michael Thomas Smith (New York: Fordham University Press, 2013), 104-22.

45 John Quincy Adams Campbell diary entry, July 9, 1861 in The Union Must Stand: The Civil War Diary of John Quincy Adams Campbell, Fifth Iowa Volunteer Infantry, edited by Mark Grimsley and Todd D. Miller (Knoxville: University of Tennessee Press, 2000), 2-3. 
hazarding my life for pure motives to sustain as far as my help will sustain the Government of our fore Fathers." ${ }^{46}$ Sgt. William Bluffton Miller of the 75th Indiana Infantry Regiment recorded that "I was once a Douglas Democrat but I am now for the Union 'right or wrong.'" He thought that "a party or Set of men who will encourage the Southern States from the North now are not fit to live under the old flag and the sooner they are put out of the way the Better."47

Pvt. Harvey Reid of the 22nd Wisconsin Infantry Regiment explained to his father that he felt "as conservative... as I ever did, but you know there is a difference between army conservatism and Northern." He said that "we are here and can see where the excuse is for many things that you call abuses" and "the wisdom of policies that you call unwise, uncalled [for], and dangerous." He summed up his view: "I cannot but believe that you and a large portion of the Democratic party are mistaken in your views, and are retarding instead of hastening the end of this horrible war." He finished, "I am right in believing it necessary for Northerners to see the war and the South, in order to form correct ideas as to the proper means of crushing the rebellion." ${ }^{48}$ One could not comment

\footnotetext{
${ }^{46}$ Joseph W. Young to Wife and Children, November 4, 1862 in The Personal Letters of Captain Joseph Willis Young, 97th Regiment Indiana Volunteers, 4th Division 15th A.C., Army of the United States, Civil War, edited by Oscar F. Curtis (Monroe: Monroe County Historical Society, 1962), 5. ${ }^{47}$ William Bluffton Miller diary entry, January 24, 1863 in Fighting for Liberty and Right: The Civil War Diary of William Bluffton Miller, First Sergeant, Company K, Seventy-Fifth Indiana Volunteer Infantry, edited by Jeffrey L. Patrick and Robert J. Willey (Knoxville: University of Tennessee Press, 2005 ), 62. ${ }^{48}$ Harvey Reid to Mother and Father, August 26, 1863 in Uncommon Soldiers: Harvey Reid and the 22nd Wisconsin March with Sherman, edited by Frank L. Byrne (Knoxville: University of Tennessee Press,
} 2001), 86-87. 
on the war without having walked in the shoes of a soldier and seen the actual conditions in the South. For Reid, as for others, personal experience shifted political leanings for the duration of the war. Crucially, these shifts remained linked to the goal of winning the war; wartime exigencies and seeing "the excuse" for controversial policies rendered such policies palatable. William Clayton, likewise, complained about the "set of men in the North who are blind to their own interests and are endeavoring to kick up a fuss... Would to God that some of the leading copperheads were compelled to come down to this region." He thought that "if they had to live here six months I think it would cure them and they would be content to go home and stay there and let the government take its own course in putting down the rebellion." ${ }^{49}$

Like Reid, Col. Francis T. Sherman of the 88th Illinois Infantry Regiment vented about the chasm between the soldiers in the field and those at home. He called for "true patriots" to "crush out traitors at home... whose minds are bent by their hellish cunning and damnable sentiments of party." He explained that his soldiers felt that "they have been ignored by all parties, and are left here to contend against disease, death, and an ever vigilant foe alone, whilst the fanatics of the North are giving aid and comfort to the rebellion. ${ }^{.50} \mathrm{He}$ also explained that he "went into this war from motives of patriotism and as a Democrat, a loyal citizen, I want to see our government reinstated and placed where she belongs. ${ }^{151} \mathrm{He}$ thought that northern politicians and southern traitors were "designing

\footnotetext{
${ }^{49}$ William H. H. Clayton to Aunt and Uncle, March 26, 1863 in Elder, A Damned Iowa Greyhound, 54.

${ }^{50}$ Francis T. Sherman to Frederick Tuttle, February 18, 1863 in Aldrich, Quest for a Star, 31-32.

${ }^{51}$ Francis T. Sherman to Father and Mother, March 8, 1863 in Aldrich, Quest for a Star, 33.
} 
men who wished for nothing more than their personal aggrandizement and to gratify an inordinate ambition to rule or ruin." 52

\section{Soldiers such as Sherman saw Copperheads as a mortal threat. Peace Democrats,} commonly known as Copperheads because of the penny with Liberty's head cut out they wore to identify themselves, were widely perceived as a domestic threat along the lines of the antebellum secret society, the Knights of Golden Circle. ${ }^{53}$ Soldiers reacted quite

\footnotetext{
${ }^{52}$ Francis T. Sherman to Father, April 3, 1863 in Aldrich, Quest for a Star, 34.

${ }^{53}$ The Copperheads have been the subject of much scholarly investigation. Questions have circulated
} around two main themes: did the Copperheads constitute a loyal opposition or something more nefarious; and the extent of popular support for the Copperhead movement. Daniel Keehn has discovered that the Knights of the Golden Circle, a secret society that aimed to expand slavery and American control over the Caribbean and Mexico, were strongest before the Civil War. Their influence in the North waned dramatically after secession. Nonetheless, their activities before the war raised fears in the North that conspirators sought to undermine the war effort. In the best study of the Copperheads, Frank L. Klement noted that opponents to the Lincoln administration were strongest in Ohio, Illinois, and Indiana as areas dependent upon the Mississippi River suffered economic collapse. Some Democrats in this area argued that "the Lincoln administration had sold its soul to New York capitalists and New England manufacturers" and "some of the administration measures made the Midwest the slave and servant of the Northeast." He also found that the dangers of Copperheads had been exaggerated and finally demolished during the 1864 presidential election. More recently, Jennifer L. Weber has argued that Klement minimized the extent and threat of Copperheads to the Union war effort. Whereas Klement had seen Copperheads more as a construction of Republican propaganda, Weber argued that "the peace movement was broad, and so influential by August 1864 that it very nearly took over the Democratic Party." More important is how soldiers spoke about Copperheads. Hubbert, 117-44; David C. Keehn, Knights of the Golden Circle: Secret Empire, Southern Secession, Civil War (Baton Rouge: Louisiana State University Press, 2013); Frank L. Klement, The Copperheads in the Middle West (Chicago: University of Chicago Press, 1960), 6, 238-41; 
hostilely to those they thought undermined the war effort. They thought that the trouble at home stemmed from the fact that craven Democrats seized on the opportunity to advance their party interests at the expense of the Union. Joseph W. Young hoped that the Copperheads would not "in courage Rebellion at home for the sake of prostrating a party or protection of party. I do not allow any man to call me a party man nor do I allow my

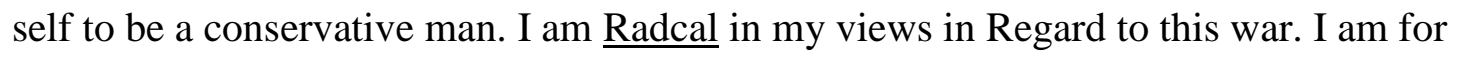
My Country, and evry man that opposes it I am his enemy." Democrats also seemed cowardly; whereas soldiers demonstrated the courage of their convictions, Copperheads shirked their duties. Young wondered why "traitors" with "Helish designs" would "not come out in the sun Shine and speek like free men and show the world there acts and there intentions but they are cowardly and Sneeking to let honest men see them." Copperheads, unlike true "free men," skulked about and employed the vicious tools of rumors and lies in service of their "Helish designs." Young noted that "I wish they could see how Our Boys Scorns such traitors Our company is composed of Democratic Material of the Simon pure and Men that Meets there [at home] and calls them selves democrats is not Democrats but they are impostors trying to deceive the true patriots." In short, true Democrats fought to save the Union and acted like men. Indeed, Young proudly reported that the men of his company had voted unanimously for resolutions "infaver of a vigerous prosecution of the war and opposed to compremise and armistace."

and Jennifer L. Weber, Copperheads: The Rise and Fall of Lincoln's Opponents in the North (New York: Oxford University Press, 2006), 10. 
He gushed that "I Never was so much gratified as to see all men come up to the standard of patriotism, Regardless of party, taking the common good of the country to heart." ${ }^{54}$ Young was not alone in thinking that Copperheads were less than men. William Bluffton Miller advised that "if they don't think enough of the Government to fight for it let them leave the country and go to Canada or come out like men and fight for the right." ${ }^{55}$ He also thought that "The Rebs come out manfully and Sacrifice their lives for their opinions and Show themselves to be men while those I find here [in the North] only talk and have not got courage to take sides openly." ${ }^{56}$ Thomas J. Davis told his wife that "I think those sneaking peace men and Copperheads are too cowardly to fight for anything. They may talk saucy to a woman or a verry old man or a small boy but they won't fight." ${ }^{57}$ Charles Musser thought the Copperheads "sneaking, cowardly, villainous." He ranted against "some of the Soldiers that have Shared our hardships...have now turned and are running on a Copperhead ticket for offices of trust and profit." He thought "it would have been better for them if they had went and hung themselves [to] a man...their manhood and principles ought to have been killed on the field of battle. then

\footnotetext{
${ }^{54}$ Joseph W. Young to Father, April 20, 1863 in Curtis, Personal Letters of Captain Joseph Willis Young, 22-23.

${ }^{55}$ William Bluffton Miller diary entry, April 11, 1863 in Patrick and Willey, Fighting for Liberty and Right, 81 .

${ }^{56}$ William Bluffton Miller diary entry, November 10, 1863 in Patrick and Willey, Fighting for Liberty and Right, 162.

${ }^{57}$ Thomas J. Davis to Lucinda, September 15, 1864 in Nanzig, The Badax Tigers, 276.
} 
their names would have been recorded in the book of fame. Arnold at one time was a great man, but one act spoiled all. there is yet Some Arnolds left." 58

Soldiers generally respected Confederate soldiers more than the Copperheads. Charles Musser found the Rebels much preferable to the Copperheads. He noted that "I have seen men down here that have served nearly three years in the rebel army and finaly came out and acknolleged that they were wrong... one of them is more honerable than the mean...cowardly copperheads. yes, ten times more would I rather a sister of mine would marry one of them reclaimed rebels than a renegade Tory, commonly called copperhead." ${ }^{59}$ George Remley explained to his brother that "I would just as soon shoot a northern traitor, who openly avows his sympathy with the rebellion and does all in his power to discourage union men and brings disgrace upon the union cause, as a southern rebel, who has the courage to take up arms and does nothing more than carry out in practice the infamous sentiments of their northern brethren." ${ }^{60}$ Sgt. Maj. Stephen Fleharty of the 102nd Illinois Infantry Regiment wrote of the Copperheads that "They are identified heart and soul with the rebellion; and with it they will sink... The soldiers feel very bitter towards these men, and have far less charity for them than they have for the deluded followers of Jeff. in the South." ${ }^{61}$ William Clayton told his brother that "nothing is thought so dispicable by a Union soldier as are those hypocritical cowards who

\footnotetext{
${ }^{58}$ Charles O. Musser to Father, September 22, 1863 in Popchock, Soldier Boy, 86.

${ }^{59}$ Charles O. Musser to Sister Hester, February 15, 1864 in Popchock, Soldier Boy, 105.

${ }^{60}$ George Remley to Howard Remley, March 19, 1863 in Holcomb, Southern Sons, Northern Soldiers, 47.

${ }^{61}$ S. F. F., Rock Island Argus, September 9, 1863 in "Jottings from Dixie": The Civil War Dispatches of Sergeant Major Stephen F. Fleharty, U.S.A., edited by Philip J. Reyburn and Terry L. Wilson (Baton Rouge: Louisiana State University Press, 1999), 138.
} 
advocate the southern cause, but are afraid to come and fight us. A rebel in arms is one hundred times more honorable than such." 62

The Copperhead takeover of the Democratic Party concerned soldiers, who often saw themselves as the true Democrats. George Remley explained to his brother how "the soldiers as a class are 'as true as stell' and will show at the coming election that they can fight for their country with ballots as valiantly as they do with bullets." The soldiers had little truck with the peace movement, and "however much of a Democrat or McClellan man he may be, he seems not to identify himself in any way with 'copperheads.' It is absolutely impossible for a true soldier to be a copperhead. We all hate them, despise them, yes even loathe them ten thousand times more than the armed traitors who oppose us in the field." 63 Thomas J. Davis, milder in his condemnation of the Copperheads by a factor of a hundred, remarked "I dispise the Northern traitors a hundred percent worse than I do those in the South." 64 The 29th Indiana Infantry Regiment sent a letter to the Rochester Chronicle where they warned: "Our motto is, 'death to traitors,' let them call themselves butternuts, copperheads, peace men or whatever title they may choose; and we desire you, that is, all true, loyal men to join us in putting down the rebellion by adopting our motto and sticking to it until traitors shall be known and heard of no more." ${ }^{65}$ Charles Musser explained to his father how "the Democrats here are not like the

\footnotetext{
${ }^{62}$ William H. H. Clayton to Brother, October 13, 1863 in Elder, A Damned Iowa Greyhound, 130-31.

${ }^{63}$ George A. Remley to Howard Remley, September 15, 1864 in Holcomb, Southern Sons, Northern Soldiers, 160.

${ }^{64}$ Thomas J. Davis to Sister, February 17, 1863 in Nanzig, The Badax Tigers, 144.

65 "Army Correspondence," Rochester Chronicle, August 13, 1863 in Indiana's Civil War: The Civil War in Documents, edited by Richard F. Nation and Stephen E. Towne (Athens: Ohio University Press, 2009 ), 83.
} 
Democrats at home. They are for the Union strong. the motto 'Peace when the Union is restored, war untill it is' and war to the bitter end. we will make a Killkeany Cat fight of it before we acknolledge the Southern indep." 66

With soldiers seeing their motives in such simon-pure terms, inevitably those at home came in for criticism. Francis Moore fumed that "I entered the service to serve my country and fight against rebellion, and not for personal advancement nor to advance others." He stated: "I have observed that many officers from generals down seem to think that the war was commenced and armies organized for their especial benefit and in order to promote them and give them opportunities to display their uniforms and stupidity." He remarked how "we have altogether too many speculating generals in the field who don't want the war to end too soon. It is worth money to them to prolong the struggle as long as possible." 67

Some western troops, over the course of the war, came to identify themselves as uniquely qualified to determine the course of the war. They devoted themselves to the preservation of the Union and saw themselves as true men. The Copperheads at home, who skulked about sowing discontent, knew not what they talked about. Because they behaved as less then men, they were not entitled to speak as real men. Thus, the peace Democrat platform failed to make inroads among the western soldiers. But the pusillanimous Copperheads at home paled in comparison to the degraded manhood that western soldiers found in the South.

\footnotetext{
${ }^{66}$ Charles O. Musser to Father, September 12, 1864 in Popchock, Soldier Boy, 150.

${ }^{67}$ Bahde, The Story of My Campaign , 190-92.
} 
Contact with whites in the South confirmed the fears of many soldiers. They saw what slavery had wrought in the South, and what it would hold for them, should the institution expand. They found most whites degraded by the slaveholding oligarchy, which had denied poor whites an education, thus rendering them pliant tools in the planters' hands. Southern troops might demonstrate bald courage, but they had lost their manly independence after years of oppression. Soldiers identified white southern leaders as the true culprits behind secession, rather than the masses of white southerners. Pvt. William Taylor Stott of the 18th Indiana Infantry Regiment confided in his diary that he was "very much settled in the belief that the people of the South are deceived by their leaders. ${ }^{68}$ William Clayton, based on his conversations with captured Confederates, came to the same conclusions that leaders had steered the populace to war. He noted "that the reports in regard to the South given in our papers telling how the people were deluded and led into it by the leading men were true, many [captured Confederates] told me that they did not fight with a good will." ${ }^{69}$

With these thoughts in mind, many western troops looked about the South and found explanations for how the common whites had been led astray. The scale of plantations in Louisiana astounded John Quincy Adams Campbell. He wrote that "after looking upon these plantations and seeing the despotic sway these few planters wielded over this whole section, I am not surprised that they should be aristocrats, nor do I

\footnotetext{
${ }^{68}$ William Taylor Stott diary entry, March 1, 1862 in For Duty and Destiny: The Life and Civil War Diary of Hoosier Soldier and Educator William Taylor Stott, edited by Lloyd A. Hunter (Indianapolis: Indiana Historical Society Press, 2010), 94.

${ }^{69}$ William H. H. Clayton to Father and Mother, July 10, 1863 in Elder, A Damned Iowa Greyhound, 83.
} 
wonder that they cling to their 'pet institution."'70 Taylor Peirce complained that the upper classes of the South were "well educated and lazy loving in a kind of bawdy aristocracy not that kind of aristocracy that arises from cultivated taste but a low born aristocracy that came by wealth." As a result, "the poor class is as low as slavs and as ignorant as the d--dst meanest of all white men. The slavs look down on them as much as the masters do on the slavs." 71

Soldiers found much more evidence of the class that they referred to as "poor white trash" as they ventured farther and farther into the South. ${ }^{72}$ Taylor Peirce commented on how "the Southern States Settled with an indolent race of poor whites who have become degraded and Idle by comeing in contact with slave labour, and the better class never having had to use any of their own exertion to procure their livelyhood have become enervated to such a degree, that the whole must succumb to the enterprise and

${ }^{70}$ John Quincy Adams Campbell diary entry, April 30, 1863 in Grimsley and Miller, The Union Must Stand, 91.

${ }^{71}$ Taylor Peirce to Wife, Sister, Brother, and Children, July 15, 1863 in Kiper, Dear Catharine, Dear Taylor, 133.

${ }^{72}$ Scholars have investigated how Union troops perceived the South, but have looked at narrow geographic regions. In general, they have found that wartime experiences confirmed antebellum stereotypes regarding Appalachia, Arkansas, and Missouri as rude and backward places. John F. Bradbury, "'Good Water \& Wood but the Country is a Miserable Botch': Flatland Soldiers Confront the Ozarks," Missouri Historical Review Vol. XC, No. 2 (January 1996), 166-186; John C. Inscoe, "'Moving Through Deserter County': Fugitive Accounts of the Inner Civil War in Southern Appalachia," in The Civil War in Appalachia: Collected Essays, edited by Kenneth W. Noe and Shannon H. Wilson (Knoxville: University of Tennessee Press, 1997), 158-186; and William L. Shea, "A Semi-Savage State: The Image of Arkansas in the Civil War," The Arkansas Historical Quarterly Vol. 48, No. 4 (Winter 1989), 309-328. 
superior Energy of the free and laborious men of the north, whose Education has been both of the mind and body."73 Here, Peirce succinctly summed up western views on the institution of slavery. Common whites, through contact with slave labor, had been degraded and thus consigned to perpetual serfdom, so far down that even "the slavs look down on them." The masters, accustomed to sloth, themselves suffered. For Peirce, the baleful effects of slavery were clear; the institution unmanned all whites who came into contact with it. The poor suffered degradation, while those who ostensibly profited from the institution became "enervated" and idle, failing to put their riches to any useful work. And contrasted with these southern whites, of both castes, were the industrious western men who possessed an education of both the mind--what the poor whites had been denied--and the body--which the rich whites never had to experience. Representative of some western conceptions, as well, was the fact that in his description of the ills of slavery, Peirce rooted his criticisms in discussion of the effect of slavery upon whites, rather than discussing the enslaved themselves.

Western troops compared their living conditions to the ones they found in the South, and once again, saw slavery as the influence that pulled white people down. John Quincy Adams Campbell found the soil "poor and the people poorer" in the South. He commented how "the universal style of the houses is like the old fashioned log corncribs" and "window-glass seems to be a luxury that most don't indulge in." He thought that the inhabitants "are as much dependent on the slaveholders as the slaves

\footnotetext{
${ }^{73}$ Taylor Peirce to Catharine and all the rest, July 16, 1864 in Kiper, Dear Catharine, Dear Taylor, 228-29.
} 
themselves. ${ }^{74}$ Stephen Fleharty remarked that "the anti progressive character of the people, could not fail to attract the attention of those who have been accustomed to the wide awake spirit that pervades western society." He judged the log cabins in the South as deficient when compared to a "neatly built, white-painted Illinois farm house." Of Kentucky, he remarked that "no one who has cultivated a western farm would be contented to live in any part of the state we have seen." ${ }^{75}$ Thomas J. Davis noted "implements for farming here is far inferior to improvement to those used in the North. Some of the plows used are patterns of fifty years ago and would be considered curiosities of the dark ages in some of the northern museums. I have not seen but one reaper and one threshing machine since I have been in the south and the threshing machine was a small, two-horse, endless-chainpower concern; a poor looking trap." 76

Sgt. Hamlin Coe of the 19th Michigan Infantry Regiment commented that "it is fact that there have been very few frame or brick houses along the Kentucky shore from Camp Hooker to Covington." ${ }^{77}$ So-called towns in Kentucky likewise failed to impress Coe; describing Nicholasville, Kentucky, he remarked "this place is sort of a one-horse town. It might have been called a city in Wildcat times. The buildings are old and dilapidated." As well as the buildings, "the inhabitants seemed to have so little enterprise

\footnotetext{
${ }^{74}$ John Quincy Adams Campbell letter to the Ripley Bee, September 24, 1862 in Grimsley and Miller, The Union Must Stand, 208.

${ }^{75}$ S.F.F., Rock Island Argus, December 1, 1862 in Reyburn and Wilson, "Jottings from Dixie," 67-68.

${ }^{76}$ Thomas J. Davis to Wife, August 1, 1862 in Nanzig, The Badax Tigers, 89.

${ }^{77}$ Diary entry, October 14, 1862 in Mine Eyes Have Seen the Glory: Combat Diaries of Union Sergeant Hamlin Alexander Coe, edited by David Coe (Rutherford, NJ: Fairleigh Dickinson University Press, 1975), 28.
} 
about them." He thought that with "free labor here and free institutions of learning, the state could not be excelled." Much like Peirce, Coe thought that the slavery and the lack of education - an absence of training of the body and the mind--led to lazy whites who "have to stand over the eternal nigger with a club to make him do anything." 78

Some soldiers returned repeatedly to perceived southern ignorance. George Cram commented on how southerners "beat all for ignorance. We scarcely saw a school house on the road. There is no enterprise or ambition whatever here. The negroes as a general thing know as much as their masters." ${ }^{79}$ When he met a southern woman who wondered what postage stamps were and how to use them, he remarked "the ignorance of the people really is amusing." ${ }^{80}$ William Taylor Stott found people in Arkansas who "did not really know whether two dimes were the same as twenty cents or not." He bemoaned that "being a slave state," Arkansas "had not schools" with which to elevate the intelligence of its citizenry. ${ }^{81}$ Francis Moore recalled a court of inquiry he convened, where out of the fourteen witnesses from the local population "only seven could write their names, and the names when written could not be read." Moore blamed "the accursed system of slavery." 82

Surgeon John Bennitt of the 19th Michigan Infantry Regiment, when administering medical examinations in Tennessee, found that only one out of twenty men could write his own name. He lamented it "one of the evils of Slavery, that they can have

\footnotetext{
${ }^{78}$ Diary entry, November 13, 1862 in Coe, Mine Eyes Have Seen the Glory, 37.

${ }^{79}$ George Cram to Mother, November 9, 1862 in Bohrnstedt, Soldiering with Sherman, 15.

${ }^{80}$ George Cram to Mother, November 20, 1862 in Bohrnstedt, Soldiering with Sherman, 16.

${ }^{81}$ William Taylor Stott diary entry, May 10, 1863 in Hunter, 168.

${ }^{82}$ Bahde, The Story of My Campaign , 86.
} 
no such schools as we have in Mich. \& all over the Free States." ${ }^{83}$ William Bluffton Miller thought that "The citizens as a general thing have no education and are too lazy or careless to work and have always depended on the Darkis to support them. ${ }^{84}$ Lt. J. F. Culver of the 129th Illinois Infantry Regiment found himself aghast at the conditions in which Southern whites lived. He told his wife: "I have read many accounts of the destitution of the poor whites of the South, but have never even conceived of their real condition. I have seen on this trip many families who scarcely seem to possess intelligence above the brutes \& scarcely were their equals in instinct \& self preservation." ${ }^{85}$ Hamlin Coe noted: "The white population is ignorant, habitually filthy and lazy. Many a one does not know the day of the month or year that is passing, while there are a selected few that are intelligent, and they invariably thank the northern school, and teacher for their training." 86

Soldiers tied the lack of education to perceived differences between the North and the South. Thomas J. Davis wrote to his wife about how "as there were no public schools in the South, poor men's children grew up like the Negroes, uneducated, and the poor

${ }^{83}$ John Bennitt to Wife, April 12, 1864 in "I Hope to Do My Country Service": The Civil War Letters of John Bennitt, M.D., Surgeon, 19th Michigan Infantry, edited by Robert Beasecker with a foreword by William M. Anderson (Detroit: Wayne State University Press, 2005), 259.

${ }^{84}$ William Bluffton Miller diary entry, December 5, 1864 in Patrick and Willey, Fighting for Liberty and Right, 286.

${ }^{85}$ J. F. Culver to Wife, September 3, 1863 in "Your Affectionate Husband, J.F. Culver": Letters Written During the Civil War, edited by Leslie W. Dunlap with notes by Edwin C. Bearss (Iowa City: Friends of the University of Iowa Libraries, 1978), 147.

${ }^{86}$ Diary entry, December 1, 1863 in Coe, Mine Eyes Have Seen the Glory, 92. 
people were thought less of in the South than Negroes from the fact that they were less profitable. They were, however, used as dupes by the rich who induced them to vote for men and measures contrary to their own Interest." ${ }^{87}$ Francis Moore thought the same, remarking that "the rulers and leaders, who are the few intelligent and educated, find it much easier to lead and rule the masses if they are kept in ignorance." He noted that "it is dangerous for the poor whites, as well as for the negroes, to know how to read, for a man who can read is very apt to think, and a man who thinks for himself cannot generally be easily beaten, cowed, and led like a bear by the nose." Further contact with white southerners only deepened Moore's conviction that "they are just as ignorant and superstitious, and as much in bondage, as the black slaves. And not until negro slavery, which is the real cause of this war, is forever abolished in every state of our country and the poor people permitted and encouraged to be educated, can the South lay any just claim to rank amongst the 'civilized and enlightened' peoples of the United States." He thought that "the South will yet come out of her baptism of fire all the better for the scorching, slavery once and forever abolished... and the eyes of the masses once opened to the fact that their leaders and masters are not really gods, and that industry and intelligence and not wealth alone are the nerves and sinews of a nation, and slave aristocracy will give way to northern thrift, education, and enterprise." ${ }^{88}$

Antebellum interpretations of masculinity led many western troops to see slavery as an institution that had to go. Many western soldiers had a high opinion of themselves as the true "bone and sinue" of Union. As stalwart, virtuous, selfless yeoman farmers they

\footnotetext{
${ }^{87}$ Thomas J. Davis to Lucinda, May 28, 1864 in Nanzig, The Badax Tigers, 251.

${ }^{88}$ Bahde, The Story of My Campaign , 86, 145, 163.
} 
saw themselves as the representatives of American masculinity. Through education and hard work, they had carved farms from the land. They sprang to the defense of the Union. Their enemies in arms--the Confederates--possessed education of mind or body, but not both. The institution of slavery, which westerners saw firsthand, had degraded the whites in the South who had come into contact with it. Even the planters, the supposed beneficiaries of the system, seemed lacking in virility. Their enemies at home--the Copperheads--had undermined their positions by displaying their base cowardice. Rather than possessing the courage of their convictions, something at least the poor white trash of the South demonstrated when they shouldered a musket to fight for the Confederacy, they shirked their manly duties, devoting their energies to attacking the soldiers. These views also fit neatly within the Slave Power conspiracy thesis, which had pointed out that southern aristocrats had manipulated the political system, using politicians, out for their own advancement, as willing tools.

Some soldiers embraced emancipation as a war measure that would hasten the end of the war. Moreover, emancipation would strike at the heart of the slaveholding oligarchy. On these grounds, soldiers found cause to support the measure. George Squier argued that "for however we try to avoid the fact, slavery (mind when I speak of slavery I mean the system of oppression practiced by the southern gentleman--not the negro, for the negro is no moore responsable for this war than is the steel blade which the assassin plunges into the heart of his victim responable for the deed of murder) is the cause of all our troubles." He wanted an unconditional end to slavery, claiming that secession had come because "it was concession to the fierce passion of slaveholding politicians, the cowardly truckling to our masters, the lordly, overbearing Southerners who have the 
dagger raised to strike us down as the reward of our years of vaselage...For long years we have submitted to these outrages with the docility of slaves as we were, and it was only by the action of our oppressors that we threw off this yoke. They forced us to vindicate our manhood, not only to slavery but to death." ${ }^{89}$ Here, Squier gave a succinct encapsulation of Western views. The slaveholding oligarchy had made slaves of northerners, who had cowardly submitted. The war gave them the opportunity to redeem themselves and "vindicate...manhood." The vindication of white manhood required the end of the institution of slavery, which had been the mainspring of the designs of the Southern "gentleman." Left out in all of this was the enslaved laborer, equated to an unthinking weapon.

Other soldiers opined on emancipation, and they often supported the measure on the grounds of wartime necessity. John Bennitt told his wife, "The 1st of Jan. may see some new policy inaugerated that will be more efficient in subduing the rebellion, \& I hope such may be the case. I could endure all this absence from loved ones more cheerfully if there was a prospect of the war being prosecuted vigorously." ${ }^{90} \mathrm{He}$ declared: "Let the fight go on till treason shall be fully punished, and the cause of the rebellion-Slavery--shall no more find a supporter or an apologist in America." ${ }^{91}$ Despite his emancipationist sentiments, Bennitt still proclaimed that "My convictions are that the Black race is inferior by nature and that if every master was a true Christian \& would treat his servants as children should be treated that a condition of servitude would be

${ }^{89}$ George W. Squier to Ellen, October 5, 1864 in Doyle, Smith, and McMurry, This Wilderness of War, 8990.

${ }^{90}$ John Bennitt to Lottie, December 22, 1862 in Beasecker, 78.

${ }^{91}$ John Bennitt to Lottie, [May 1863] in Beasecker, 119. 
better for them than unconditional emancipation...but as the case is now it seems to me that compensated labor would pay better \& leave the negro in some degree responsible for his own conduct." 92

Others held views similar to Bennitt's. William Bluffton Miller initially worried about the Emancipation Proclamation, fearing that "it will cause a war" in the North. He noted that "A great many Soldiers condemn it on that account." 93 As it became apparent that no war would erupt in the North on account of Lincoln's proclamation, Bluffton wholeheartedly supported the measure because "it gives us advantage." He cheered the potential enlistment of African Americans into the Union Army "as they can stop a Rebbel Bullet as well as a white Soldier." 94 One Wisconsin soldier correspondent, "Grape," argued that the Emancipation Proclamation made sense only as a war measure. He noted that "soldiers are universally pleased to see that the President has not been swerved from the course he had previously marked out, by the pressure brought to bear upon him, by tender conscience politicians and rebel sympathizers." The soldiers understood that the Emancipation Proclamation would make their jobs easier, and "no one can be in active service six months, no matter what his political predilections were when he entered the army, without having the conclusion forced upon him that the very blow struck at slavery is a blow to crush the rebellion and restore the Union." $\mathrm{He}$ explained that soldiers' views changed because "observation soon teaches him that

\footnotetext{
${ }^{92}$ John Bennitt to Lottie, March 3, 1864 in Beasecker, 244.

${ }^{93}$ William Bluffton Miller diary entry, February 20, 1863 in Patrick and Willey, Fighting for Liberty and Right, 69.

${ }^{94}$ William Bluffton Miller diary entry, July 16, 1863 in Patrick and Willey, Fighting for Liberty and Right, 112.
} 
African slavery is the foundation, the moving spirit of this unholy war...; that it is in itself an aggressive anti-republican institution, totally antagonistic in its nature to our form of government." 95

Francis Sherman thought that "this war must never cease until the fire brand of slavery is utterly quenched," something he called for though he avowed himself "as good a Democrat as ever." ${ }^{96}$ He thought that citizens need to "throw away all party feelings and strife; bury the hatchet of political warfare and all unite for the single purpose of restoring our government and country to her former proud position, and one flag." Once the war had been won, "we will go back to our political principles once more." ${ }^{97}$ Harvey Reid, likewise, noted that "I thought at the time that measure was first introduced that it was unwise, but time and experience, has...proved it most wise." He explained that spending time in the South gave soldiers "means of judging not enjoyed by those living at a distance from the seat of war, and they know the measures to be of the utmost practical benefit." 98

Even those soldiers who did not support the Emancipation Proclamation said that they would uphold it. As they had pledged themselves to the Union cause, they would honor their word and stand behind the policies of the government. J. F. Culver expressed unease over the Emancipation Proclamation, telling his wife that "I tremble for the

\footnotetext{
95 "Grape," December 9, 1862 in This Wicked Rebellion: Wisconsin Soldiers Write Home, edited by John Zimm with a foreword by Michael Edmonds (Madison: Wisconsin Historical Society Press, 2012), 207-08.

${ }^{96}$ Francis T. Sherman to Father, May 7, 1863 in Aldrich, Quest for a Star, 37.

${ }^{97}$ Francis T. Sherman to Father, November 9, 1863 in Aldrich, Quest for a Star, 73.

${ }^{98}$ Harvey Reid to Pa, September 19, 1863 in Byrne, Uncommon Soldiers, 92.
} 
results." Despite this, he noted that "under my oath I shall fight under any approved policy." 99

Soldiers, gripped by war weariness and hatred of those at home who seemed to prolong the conflict through their opposition to it, supported emancipation. Crucially, the Emancipation Proclamation's enjoinder to enlist African Americans into the Union army came in the winter of 1863 , when the morale of Western armies had reached its nadir with stalled campaigns and an extraordinarily bloody fight at Stones River. With a stagnant strategic situation and no end in sight, soldiers could support emancipation as a war measure. When Adj. Gen. of the United States Army Lorenzo Thomas embarked on a speaking junket throughout the Mississippi River Valley to recruit black troops and convince soldiers of that necessity, he found an audience that reluctantly supported the measures. Troops also supported the measure because it would further upset the Copperheads at home.

But grudging western support of the United States Colored Troops rested more upon self-interest than any acceptance of African Americans as equals. William Henry Harrison Clayton found that "the negroes make better soldiers than I expected they would." Despite that, he avowed "I do not much like the idea of soldiering with them and believe that it would have been better never to have armed them." ${ }^{100}$ Allen Geer recorded in his diary: "Had earnest discussion upon the policy of arming negroes to fight our battles for us. I am conscientiously opposed to it in every manner 1st because it is inhuman, 2nd unprecedented, and $3 \mathrm{~d}$ because it would be selfish and cowardly on our

\footnotetext{
${ }^{99}$ J. F. Culver to Wife, December 31, 1862 in Dunlap, "Your Affectionate Husband, J.F. Culver", 72.

${ }^{100}$ William H. H. Clayton to Brother, August 27, 1864 in Elder, A Damned Iowa Greyhound, 119.
} 
part to bring a people into this war to fight our battles and lose their lives who have no interest in the result." ${ }^{101}$ Andrew McGarrah of the 63rd Indiana Infantry Regiment complained about enlisting African Americans, telling his family that "The Idea of adopting the negro into the United States service seems to me to be useless." He feared that if "they come in to United State Service and help us to restore our union then of course they would consider and justly too that they were entitled to the fellowship of the american people, and equalize themselves with $u s, \&$ that will never do."102

The arrival of General Thomas in the West to organize the recruitment of the United States Colored Troops changed the opinion of some westerners. Beyond a simple administrative visit, Thomas embarked on a lengthy public relations tour of the Mississippi River Valley delivering speeches to white troops trying to convince them to support the government's policy of arming formerly enslaved African Americans. Allen Geer related how "Gen. Thomas an old grey haired roman nosed patriot... addressed us in a slow, solemn, imposing manner, stating his object and powers...to organize Negro regts. To place the old decrepit women and children on plantations deserted by their owners." Geer found it "such a speech before I never heard. So lofty, eloquent, \& patriotic it electrified, convinced, \& carried the 3d Div Cols Stevenson, Ligget, \& Gen. McArthur spoke well."103

Thomas, far from a paper-pushing bureaucrat in a starched collar, looked the absolute part of stalwart patriot. When he spoke to the soldiers, they saw a man in the

\footnotetext{
${ }^{101}$ Diary entry, July 17, 1862 in Anderson, The Civil War Diary of Allen Morgan Geer, 43.

${ }^{102}$ Andrew J. McGarrah to Parents, Brothers, and Sisters, March 8, 1863 in Nation and Towne, Indiana's Civil War 119.

${ }^{103}$ Diary entry, April 8, 1863 in Andersen, The Civil War Diary of Allen Morgan Geer, 88-89.
} 
model of their officers, not some pusillanimous politician out for self-promotion. Jacob Ritner described the visit of Thomas to his men. After his speech, "the sentiment was universally in favor of the new policy. Some had always approved it, others declared that if it had been adopted a year or more ago they would have opposed it, but now supported it heartily, and there was not the least murmur of disapprobation among the soldiers." The speeches of Thomas, and later Maj. Gen. Frederick Steele, excited the men, who gave "the most radical sentiments...the loudest cheers." Ritner avowed that he "never saw more enthusiasm and unanimity in any meeting, or head more eloquent and patriotic speeches. It was good to be there. The army now is all right--there is no mistake about that." 104

In part through such efforts at persuasion, soldiers came to accept the enlistment of African Americans despite their racial antipathies. One soldier correspondent informed readers that "The soldiers, as a general thing, are well pleased with the idea of arming the negroes. Those who but a few weeks since were bitterly denouncing the arming of negroes... are now strong advocates for the measure." He crowed that "it will be a bitter pill to the 'chivalry' indeed, but it would be the 'most unkindest cut of all' to the 'dear Copperheads.'" ${ }^{105}$ In D. W.'s analysis, soldiers came to accept the "arming of negroes" not out of any beneficent moral urge but because the act would strike at the "chivalry" and upset the Copperheads.

Francis Moore also greeted the enlistment of black troops with qualified optimism. He remarked that "the negro in the South is a strong element of war, and I have

\footnotetext{
${ }^{104}$ Jacob Ritner to Emeline Ritner, April 29, 1863 in Larimer, Love and Valor, 159-60.

${ }^{105}$ D. W., April 24, 1863 in Zimm, This Wicked Rebellion, 141.
} 
always been in favor of making use of him. If we cannot make soldiers of the negroes, they can at least work in trenches and elsewhere, thus relieving our soldiers of much labor and giving us just so many more effective fighting men, besides depriving the enemy of their help." On these grounds, the course of the war justified enlisting African Americans into United States service. However, Moore expressed skepticism that blacks would make good soldiers, musing: "But it is hardly reasonable to expect that the poor wretches, ignorant and superstitious, and for generations past down-trodden and oppressed...should stand up and fight like men." He felt that "like well trained dogs" they would "lick the hand that strikes them. Years of slavery have made them craven. They have the muscles and sinews of oxen, but I fear not the hearts and nerves of men." Despite these doubts, also noted that "it is said, and truly too, that 'a coward in a corner will fight like the devil'" and that "a corner can readily be found" for the United States Colored Troops. ${ }^{106}$ Francis Moore wryly noted that "The Copperhead bugbear of 'nigger equality' was quite forgotten when 'niggers' wanted to take their places in the army and stand between them and their Southern rebel friends." ${ }^{107}$

Soldiers could also embrace emancipation and the arming of African Americans as a war measure without revising their opinions of black people. Charles Wills wrote that "hundreds of the officers... are emancipationists, as I am, if the brutes could be shipped out of the country." ${ }^{108}$ Wills eventually approved of the arming of blacks, but declared himself "by no means an enthusiast over the negro soldiers yet. I would rather

\footnotetext{
${ }^{106}$ Bahde, The Story of My Campaign , 120.

${ }^{107}$ Bahde, The Story of My Campaign , 205.

${ }^{108}$ Letter, August 14, 1862 in Kellogg, Army Life of an Illinois Soldier, 126.
} 
fight the war out without arming them...but I don't pretend to set my voice up against what our President says or does...I have no trouble believing that the Rebels should lose every slave they possess; and I experience some pleasure in taking them when ordered to." ${ }^{109}$ Andrew Bush of the 97 th Indiana Infantry Regiment grumbled that "I don't like old Abe's proclamation...If I had thought that it was the idea to set the negroes all free they would not have got me to act the part of a soldier in this war." Despite this, Bush noted "I am willing to fight for the Union if it will cause the freedom of the last beastly negro in the South for I don't think that they are human." He explained that "I am in for anything that will cause Union and peace for our once happy government." ${ }^{110}$ Later, after some consideration, Bush thought that the Emancipation Proclamation "was the best thing ever put forth...for I think it will put an end to the black population, for the Secesh are killing the negroes that are found in our employ as fast as they can get ahold of them." Bush commented that "the next proclamation that Old Abe puts out I wish he could make it so we could shoot all the negroes we see for I hate them worse every day, and I intend to shoot one every time that I can get the chance to for I don't think that they are human beings." 111 Thomas J. Davis remarked "I would almost give my existence to see every Nigger removed from the face of the American continent and the whole Southern Confederacy (that is their power) crushed to the earth, never more to rise and every northern office-seeking traitor piled on the ruins, there to moulder through eternal ages as a public example to future traitorous rotton-hearted, office-seeking, political aspirants." ${ }^{112}$

\footnotetext{
${ }^{109}$ Letter, May 29, 1863 in Kellogg, Army Life of an Illinois Soldier, 176-77.

${ }^{110}$ Andrew Bush to Mary, February 11, 1863 in Nation and Towne, Indiana's Civil War, 113-14.

${ }^{111}$ Andrew Bush to Mary, March 26, 1863 in Nation and Towne, Indiana's Civil War, 115.

112 Thomas J. Davis to Sister, February 17, 1863 in Nanzig, The Badax Tigers, 143.
} 
Charles Cox simply stated "I do not like the niggers, and desire them all 'put away' our first opportunity...I do despise them and the more I see of them, the more I am against the whole black crew."113

The sentiments of Jacob Ritner presented a common feeling of many western troops towards the enlistment of African Americans. He informed his wife: "The soldiers have all got to be in favor of setting the Negroes free, and arming them too. They see that this is the quickest way to end the war, and that is all they want. Although this is the universal sentiment as far as I know, yet there is just as much prejudice against them as there ever was. There is always someone trying to abuse, insult, and impose upon them." ${ }^{114}$ He further elaborated that "the sooner the slaves are taken away from the rebels, the sooner the war will be over and the sooner [the men] will get to go home. You can't convince a soldier that a Negro is too good to carry a gun and knapsack when they have to do it themselves. I suppose our copper-head secesh friend in the North will be very much shocked at this, and raise a great howl. Well, if they don't like it let them enlist, and take the Negro's place." 115

The degree to which western soldiers embraced emancipation as a war measure resulted in little revision of their attitudes towards the enslaved themselves. The poverty that soldiers encountered in the South confirmed their earlier fears that slavery would eventually enslave the common white man and secession seemed to be a step towards this goal. The soldiers therefore saw emancipation primarily through the lens of their deepest

\footnotetext{
${ }^{113}$ Charles H. Cox to Katie, August 28, 1863 in Sylvester, "The Civil War Letters of Charles Harding Cox," 64.

${ }^{114}$ Jacob Ritner to Emeline Ritner, April 17, 1863 in Larimer, Love and Valor, 154.

115 Jacob Ritner to Emeline Ritner, April 22, 1863 in Larimer, Love and Valor, 157.
} 
fears of being degraded by slavery. Thus, their opposition to slavery lay almost entirely upon their own fears and anxieties rather than a positive desire to ameliorate the conditions for African Americans in the South. Western troops tended to lump the enslaved African American population of the South into a long list of strange sights that they found novel at first. Thus, while the war had convinced Westerners of the need to end the institution of slavery, it did little to force them to revise their antebellum prejudices, and indeed may have strengthened them.

The scale of the plantations, beyond betokening aristocracy in its American guise, disturbed soldiers. Here, they saw evidence of the hordes of African Americans waiting to flood into their states. These sights activated antebellum anxieties. Sgt. Maj. Charles H. Cox of the 70th Indiana Infantry Regiment wrote about coming across a plantation with an enslaved workforce of 250 . He wrote home that "I never saw so many niggers in a huddle before." ${ }^{116}$ Pvt. Henry Rice of the 11th Iowa Infantry Regiment commented on "quite extensive plantations here along the river" and how "the niger huts look like a little town some of them as large as rochester and some of them I believe larger." ${ }^{117}$

Soldiers found dealing with enslaved African Americans an annoyance. Charles W. Wills expressed frustration with the large numbers of slaves the army had to deal with in Mississippi. He told his wife: "Candidly, I'd rather see them and a whole crop of grindstones dumped into the Gulf than have so many of them in our State, as there are

\footnotetext{
${ }^{116}$ Charles H. Cox to Sister, December 5, 1862 in Sylvester, "The Civil War Letters of Charles Harding Cox," 40.

${ }^{117}$ Henry Rice to Mr. Johnston and family, January 29, 1863 in "The Civil War Letters of Henry Rice and James Nolan," edited by Curtis Frymoyer, The Cedar County Historical Review (June 1961), 15.
} 
even here." ${ }^{118}$ Returning to the theme in a later letter, he elaborated that "You have no idea what a miserable, horrible-looking, degraded set of brutes these plantations hands are...we surely don't want our Northern States degraded by them." ${ }^{119}$ Hamlin Coe found little to like when he encountered enslaved African Americans, and remarked balefully "the more I see them, the more I pity the cause of freedom that is about to be proclaimed. We do not want them among us at the North, and certainly such an ignorant and brutal set as I have seen today cannot take care of themselves." ${ }^{120}$ Here, the fears of some westerners had been confirmed. Antebellum laws had kept African Americans out of most western states over fears that blacks would degrade them.

Like Wills, other soldiers quickly tired of dealing with contrabands. Harvey Reid told his sisters that "the romance of coaxing negroes into camp has, however, about 'played out' in the soldier's parlance." He found "them lazy, saucy, and lousy." ${ }^{121}$ Charles Musser complained that "i never did like the darky, and you may believe i do not now" because "most of them are lazey around and are expense to government." ${ }^{122}$ Time only strengthened Musser's opinions, as more than a year after he complained about laziness, he told his father that "The Nigger question is quickly settled among us now. we have nothing to do with him. we dont like the nigger. we wish they were in Guinea. we have seen too much of them...I avoid them, dont have anything to do with them at all. we dont

\footnotetext{
${ }^{118}$ Letter, June 19, 1862 in Kellogg, Army Life of an Illinois Soldier, 106.

${ }^{119}$ Letter, August 19, 1862 in Kellogg, Army Life of an Illinois Soldier, 127.

${ }^{120}$ Diary entry, December 25, 1862 in Coe, Mine Eyes Have Seen the Glory, 42.

${ }^{121}$ Harvey Reid to Sisters, November 11, 1862 in Byrne, Uncommon Soldiers, 15.

${ }^{122}$ Charles O. Musser to Father, February 3, 1863 in Popchock, Soldier Boy, 25-6.
} 
want the negroes among us." ${ }^{123}$ George Cram opined, "for my own part I am disgusted with Negroes, although I think slavery is wrong and hope, as I believe, that the war will end it on this continent or at least in this government." ${ }^{124}$

Western troops quickly appropriated African American labor, engaging formerly enslaved individuals to perform menial tasks around camp. Though soldiers liked that the black people carried out tasks that they did not want to do, familiarity ended up breeding contempt and cruelty. Charles Wills told his wife about how the servant he had hired had a number of children, whom he supported without getting anything in return. He joked that "I can send you a nigger baby if it would be acceptable. They are more 'antic' than either a squirrel or a monkey." He complained that his two male servants, though doing a good job for him, also had wives and children to support. Wills fumed to his wife, "Think I will either have to drown the babies, or sell them and the women, whom I endure because their husbands are such good hands. Will you take one?"125 Thomas J. Davis wrote to his wife that his men sought to remove men alone from plantations, as they could perform useful work for the Union. They had to fend off the "wenches and children" who would not be able to provide labor. ${ }^{126}$ Ransom J. Chase, also of the 18th Wisconsin Infantry Regiment, reported that "our regiment took a number--probably a dozen" of contrabands. Davis like that "we have now niggers to forage for us on a march

\footnotetext{
${ }^{123}$ Charles O. Musser to Father, September 12, 1864 in Popchock, Soldier Boy, 150.

${ }^{124}$ George Cram to Mother, August 20, 1864 in Bohrnstedt, Soldiering with Sherman, 135.

${ }^{125}$ Letter, January 16, 1863 in Kellogg, Army Life of an Illinois Soldier, 148.

${ }^{126}$ Thomas J. Davis to [Wife], August 1, 1862 in Nanzig, The Badax Tigers, 89.
} 
and help cook in camp. When I come home I shall try and bring a young boy home with me just as a curiosity." 127

While some soldiers found African Americans curiosities, worth shipping home as novel pets, others thought them more similar to livestock or pests. These comparisons remained rooted in fears that African Americans, much as harmful animals might, would swarm western states. Charles Wills, always the incorrigible racist, stated, "I don't like to see them introduced into our State, for they increase like rabbits." ${ }^{128}$ William Bluffton Miller thought that the "Slaves here are more monkey than human." ${ }^{129}$ Pvt. Silas Haven of the 27th Iowa Infantry Regiment classed African Americans as just another one of a long list of annoyances in the South. He complained to his daughter of the "flies" and how "there is any quantity of gnats, fleas, mosquitoes, lice (we call them graybacks), besides other kinds too numerous to mention. Dogs, cats, rice, mice and goats are plenty, and Negroes are also a southern institution take them all together. I had rather be excused from living where they are as numerous as they are here." ${ }^{130}$ Later, Haven gave another comprehensive list of the menagerie he found in the South to his wife, fretting about "the insects and vermin that breeds here, such as body lice, flees, jiggers and flies by swarms and other things too numerous to mention. I have not seen but a few snakes, but any quantity of lizards...I don't think I want to live down here, especially among the

\footnotetext{
${ }^{127}$ Ransom J. Chase to Sister, August 1, 1862 in Nanzig, The Badax Tigers, 87.

${ }^{128}$ Letter, March 31, 1863 in Kellogg, Army Life of an Illinois Soldier, 166.

${ }^{129}$ William Bluffton Miller diary entry, February 12, 1865 in Patrick and Willey, Fighting for Liberty and Right, 308

${ }^{130}$ Silas W. Haven to Daughter Ella, July 12, 1863 in "A Punishment on the Nation": An Iowa Soldier Endures the Civil War, edited by Brian Craig Miller (Kent, OH: Kent State University Press, 2012 ), 79.
} 
Negroes." ${ }^{131}$ Capt. Thomas N. Stevens of the 28th Wisconsin Infantry Regiment placed African Americans in the same category as livestock: "we have 'heaps' of niggers here...The principal productions of this country [Arkansas] seem to be darkies \& mules." ${ }^{132}$ Many western soldiers, already fearful of African Americans, saw little to change their impressions in the South. African Americans, at best, seemed novel curiosities, circus sideshows, and at worst, vermin that bred wildly, bedeviling white men.

When not comparing blacks to lice, fleas, and reptiles, soldiers sometimes found amusement in the appearance of African Americans. Thomas J. Davis wrote of how some of the men took great pleasure in observing an African American celebration at Christmas; "the Niggers had a jollification dance uptown at night in honor, I suppose, of Massa Lincum'z Proclimation but I did not feel enough interested on that important occasion." ${ }^{133}$ Thomas Stevens found African American women especially amusing. He told his wife that "It would do you good to be here on Sunday... and see the darkey women out in their finery." He described the spectacle for her: "fine silk dresses, Lace shawls \& mantillas, fancy hats 'with buttons all over' them. Oh, it is gay! Black as the ace of spade, with lips on which you could hang a hat, they get on their fine attire on Sunday, and aint they grand?"134

\footnotetext{
${ }^{131}$ Silas W. Haven to Jane Haven, September 7, 1863 in Miller, "A Punishment on the Nation", 95.

${ }^{132}$ Thomas N. Stevens to Father, June 14, 1863 in "Dear Carrie...": The Civil War Letters of Thomas N. Stevens, edited by George M. Blackburn (Mount Pleasant, MI: Clarke Historical Library, 1984), 115.

${ }^{133}$ Thomas J. Davis to Mr. Lincoln \& Co, December 29, 1862 in Nanzig, The Badax Tigers, 127.

134 Thomas N. Stevens to Carrie, June 14, 1863 in Blackburn, "Dear Carrie...", 114.
} 
Other troops tormented the African Americans in camp as a form of amusement. Pvt. John M. King of the 92nd Illinois Infantry Regiment confided in his diary about how soon the men became tired of African Americans and turned upon them. In Alabama, King recorded that "we were all friendly with the slaves and inquired all about their servitude; how they liked to be slaves; would they like to be free; did their overseers whip much; and a thousand and one questions of this nature were asked." But as the novelty wore off, the men became more hostile. King reported that "men soon become tired of any medicine when taken in overdoses" and the men "were taking overdoses of negro hardship. We wanted a rest, but the poor, ignorant things had but little knowledge of propriety." Tired of the black visitors in their cabins, the soldiers built a large fire and placed cartridges among the coals. As King described it, "the little 'nigs' and the old 'nigs'" crowded around the flames to get warm on the cool evening. As the cartridges began to explode, "the darkies...stampeded for the door." When the affair finished, "there was not a negro in rifle shot of the cabin." ${ }^{135}$ Charles Wills recounted an incident where an Iowa soldier "filled an oyster can half full of powder, set a slow train to it and placed it in the ground, they then set a cracker box over it and got a negro to dancing on the box. A coal was then touched to the train and the 'nigger' was blown full 20 feet." Though physically unharmed, the unfortunate victim "was crazy for an hour." ${ }^{136}$ Francis Moore, upon seeing United States Colored Troops for the first time, commented that they looked "as wild and brave as oxen" and laughed about "how they manage to 'order arms' without

\footnotetext{
${ }^{135}$ John M. King diary entry, February 16, 1864 in Three Years with the 92d Illinois: The Civil War Diary of John M. King, edited by Claire E. Swedberg (Mechanicsville, PA: Stackpole Books, 1999), 180-81.

${ }^{136}$ Letter, September 27, 1863 in Kellogg, Army Life of an Illinois Soldier, 192.
} 
serious inconvenience I don't know, for as they stood in line, no ground could be seen between their feet. Their feet seemed to occupy as much space as their shoulders. They are known here as the 'web footed brigade."'137

When westerners abused African Americans, they did so in order to reassure themselves of their own superiority. Some westerners' conception of masculinity precluded them from recognizing African Americans as their equals; disparaging comments and violence directed at black people fit within these westerners' view of themselves and the Slave Power conspiracy thesis. While many soldiers grudgingly accepted African American enlistment, some of their other comments and actions helped contain the implications that African Americans were deserving of equality and worthy of participation in American republicanism. Soldiers from the urban northeast would participate in a similar process, but would fit their actions within the framework of the antebellum popular entertainment of the blackface minstrel show, which provided a more rigid template for behavior.

Western soldiers saw the war through antebellum contexts of masculinity intersecting with the Slave Power conspiracy thesis, and in this they differed little from soldiers from other regions. Soldiers from Indiana, Illinois, Iowa, Michigan, and Wisconsin shared a concept of masculinity rooted in the ideal of the hardy frontier farmer, who set aside his plow and shouldered a musket in defense of law and order, an idea that distinguished them from their comrades. This idea of the frontier farmer had a long heritage in America, but the particular iteration of the idea, combined with free labor ideals and an abiding racism, marked the masculinity of western troops. They zealously

${ }^{137}$ Bahde, The Story of My Campaign , 136. 
defended their independence; reflecting the dangerous environment of the West, they put a premium on honor, courage, and grit rather than restraint or refinement. These values helped to sustain the soldiers through personal hardships and flagging morale. Ironically, their dedication to destroying the Confederacy in the most expedient way possible led them to embrace emancipation, despite deep personal dislike for African Americans. Contact with African Americans only intensified their fears that black people degraded whites in proximity to them. Furthermore, African Americans seemed little better than beasts or pests, not worthy of being recognized as people. In this fashion, Western troops shattered the Slave Power by destroying the institution of slavery in a process that left their antebellum prejudices and anxieties relatively untouched. 


\section{Chapter 3:}

\section{"Equal to any Minstrel Concert I Ever Attended at Home": Union Soldiers and Blackface Minstrelsy as a Strategy of Containment \\ $* * * * * * * * * *$}

On July 18, 1863, pensive Union troops gathered in the gloaming outside of Charleston, South Carolina. Union Maj. Gen. Quincy A. Gillmore had decided to assault an imposing Confederate fortification, Fort Wagner. Built of sand and palmetto logs, Wagner would serve as the proving ground for the African-American 54th Massachusetts Infantry Regiment commanded by Robert Gould Shaw, the privileged son of abolitionists. As the evening deepened and fog rolled in off of the sea, the storming column formed. At about 7:45 p.m., the attack began as the Union troops moved up the narrow ribbon of sand toward Wagner at a quick-time march. All remained quiet until the men came within two hundred yards of the fort's walls. Then, as a veteran of the 54th described it years later, "Wagner became a mound of fire...A sheet of flame, followed by a running fire, like electric sparks, swept along the parapet." Shaw ordered his men to charge at the double-quick, and his troops "with set jaws, panting breath, and bowed heads, charged on." In the face of the shot and shell that tore into them, followed by close-range fighting, the black troops could gain little ground during their assault. Union troops failed to make any lasting headway against the Confederate works. In the wake of the assault, Confederates dumped the bodies of the fallen black troops into the ditch at the front of the parapet. To express their hatred of Shaw, who had been killed during the 
attack, the Confederates unceremoniously dumped his corpse into the ditch to lie with his troops, denying him any of the customary honors of burial that befit an officer. ${ }^{1}$

For many scholars, and in popular culture, the immolation of the 54th

Massachusetts stands as the entire story of the assault on Wagner. Indeed, the martyrdom of Robert Gould Shaw and his men appears as an example of how the Civil War wrought a change in antebellum attitudes. Shaw, though the child of Boston Brahmin abolitionists, had only come during the course of the war to embrace the cause of freedom. Amid the death and destruction, the 54th Massachusetts and other United States Colored Troops proved to the nation that they were men and belonged. Through their combat service they demonstrated courage, independence, and strength. In popular culture, and historiography, the 54th Massachusetts embodies the Civil War as a struggle for emancipation and the first steps toward equality in America. ${ }^{2}$

A week later, soldiers enacted a far different drama in St. Augustine, Florida, to commemorate the Union assaults on Wagner. On July 22 and 25, members of the 7th

\footnotetext{
${ }^{1}$ Luis F. Emilio, A Brave Black Regiment: The History of the 54th Massachusetts, 1863-65, new introduction by Gregory J. W. Urwin ([1894] New York: Da Capo, 1995), 67-80.

${ }^{2}$ For discussion of Shaw and the 54th Massachusetts Infantry Regiment, see: Peter Burchard, One Gallant Rush: Robert Gould Shaw and His Brave Black Regiment (New York: St. Martin's Press, 1965); Blue-Eyed Child of Fortune: The Civil War Letters of Robert Gould Shaw, edited by Russell Duncan (Athens: University of Georgia Press, 1992); and Russell Duncan, Where Death and Glory Meet: Colonel Robert Gould Shaw and the 54th Massachusetts Infantry (Athens: University of Georgia Press, 1999). For a discussion of how the story of Shaw and the 54th Massachusetts Infantry Regiment has become a theme in popular understandings of the Civil War, primarily due to the success of the feature film Glory (1989), see Gary W. Gallagher, Causes Won, Lost, and Forgotten: How Hollywood and Popular Art Shape What We Know About the Civil War (Chapel Hill: University of North Carolina Press, 2008), 95-100, 125.
} 
Connecticut Infantry Regiment held a benefit for their comrades who had been wounded in South Carolina. Pvt. Henry Lardner and Pvt. William H. Clark played their violins, accompanied by Sgt. Oscar W. Cornish on the guitar, Pvt. William H. Wheelock on the banjo, and Henry H. Taylor on the bones. Sgt. John J. Cochrane and Pvt. William H. House both played tambourines, while Pvt. Henry Longden and Cpl. John H. Bario sang. One soldier even wore a dress and wig in his role as a female dancer. The soldiers, rather than putting on a simple musical concert, all wore blackface that they had made from a mixture of burnt cork and grease paint. The soldiers mimicked the blackface minstrel shows they had seen back home in New Haven and Boston, including in their show what they considered as comic songs, laughable dialogues, ribald jokes, and slapstick humor. ${ }^{3}$

With their performance, they reassured themselves that African Americans differed little from the grotesqueries of the minstrel stage and therefore posed little threat to the social and economic status of the white troops even as emancipation and service of black men in the Union army threatened to disrupt antebellum racial hierarchies. According to historian Alice Fahs, blackface minstrel shows worked as "a strategy of containment" that "reassured white northerners that even in freedom African Americans remained no more than property and that familiar images from minstrelsy retained their currency in wartime as a mode of imagining blacks." ${ }^{4}$ Such a strategy proved particularly

\footnotetext{
${ }^{3}$ The full names of soldier performers are drawn from the roster at the end of Stephen Walkley, History of the Seventh Connecticut Volunteer Infantry, Hawley's Brigade, Terry's Division, Tenth Army Corps 1861 1865 (n.p.,n.d.), vii-lv. "CONN. 7th MINSTREL TROUPE," New Haven Daily Palladium (New Haven, CT), August 26, 1863, Issue 205, pg. 1, col. B.

${ }^{4}$ Alice Fahs, The Imagined Civil War: Popular Literature of the North and South, 1861-1865 (Chapel Hill: University of North Carolina Press, 2001), 152.
} 
important for soldiers from the urban northeast because their antebellum culture had been largely predicated upon white supremacy. Finding a way to minimize and deflect the radical and egalitarian implications of emancipation proved critical for sustaining their support for the Union.

Such a strategy of containment also nested easily within the framework of the Slave Power conspiracy, which held that a white southern slaveholding oligarchy sought to destroy republicanism, a tenet that allowed soldiers from different regions to decide for themselves the role of African Americans within the Civil War and their place in the nation after it. Some white soldiers from the urban Northeast embraced the notion of the Slave Power conspiracy, seeing the conflict as a struggle for control of the Union between republicanism and aristocracy.

Some urban troops named the Slave Power explicitly. Maj. Benjamin Willis of the 119th New York Infantry Regiment wrote that the war had been "begotten by the existence of anti-republican elements, whose growth depended not upon moral suasion, but upon the exercise of power." He explained: "You know what I mean, the Slave Power, to which the whole patronage of the Government had been subordinate." The Slave Power had corrupted "commercial interests," "presses," "religion," so "that it might be enlarged, popularized, and nationalized." ${ }^{5}$ Willis gave a concise summary of the Slave Power conspiracy theory, showing how its tentacles had worked their ways into nearly all aspects of a putatively republican society. When the population of the North had sought

\footnotetext{
${ }^{5}$ Benjamin Willis to My Dear Friend, May 19, 1863 in Soldiers' Letters from Camp, Battle-field and Prison, edited by Lydia Minturn Post (New York: Bunce \& Huntington, 1865), 245.
} 
to diminish the suzerainty of the South over the country, the Slave Power had struck to preserve its own interests.

Willis gave a thorough explanation of the Slave Power, but other troops only implicitly identified it. Capt. Henry Warren Howe of the 30th Massachusetts Infantry Regiment blamed a "Southern cabal" for bringing on the war and declared that "we are still willing to endure privations... rather than submit to the cabalistic intentions of the rebel traitors, who, if successful in their well plotted plan, would stigmatize forever the flag which our father dearly bought." ${ }^{6}$ Howe implicitly referenced the Slave Power conspiracy theory through his reference to a shadowy cabal of traitors.

Other urban soldiers thought that the white southern masses had been dragooned into serving the Confederacy, a position consistent with the Slave Power conspiracy theory. In these accounts, the Southern masses had not sincerely wanted secession, but had been forced into it by their leaders. A soldier letter published in a New York newspaper informed readers that "there has been much misrepresentation made to the people of the South by their leaders." ${ }^{7}$ An editorial in the same paper reflected upon how "'poor whites'... are forced...to fight the battles of Aristocracy and Slavery--the battles of

\footnotetext{
${ }^{6}$ Henry Warren Howe diary entry, July 8, 1861 in Passages from the Life of Henry Warren Howe: Consisting of Diary and Letters Written During the Civil War, 1861-1865 (Lowell: Courier-Citizen Press, 1899), 20; and Henry Warren Howe to , February 7, 1863 in Passages from the Life of Henry Warren Howe, 133.

${ }^{7}$ T. O. M., "Acquia Creek, VA.," New York Sunday Mercury, May 21, 1862 in Writing and Fighting the Civil War: Soldier Correspondence to the New York Sunday Mercury, edited by William B. Styple (Kearny, NJ: Belle Grove Publishing, 2004), 90.
} 
a privileged bullying caste--against their own rights and those of mankind." ${ }^{8} \mathrm{~A}$ correspondent from the 31st New York Infantry Regiment asked for the country to set aside partisan difference and "unite for the Union and liberty; for, if the 'chivalry' should ever get the better of us, God help us!" He also thought there was "no reason why we should abandon the Republic to a pack of aristocratic" white southerners. ${ }^{9}$ Other soldiers referred to the southern gentry as "landed proprietors," underscoring the tie between secession and aristocracy. ${ }^{10}$

These accounts all demonstrate how for some soldiers, the Slave Power conspiracy theory provided a convincing explanation for the Civil War. Critically, the Slave Power allowed them to explain the coming of the Civil War without any direct reference to the millions of enslaved African Americans in the South. For some of these northern soldiers, the Slave Power thesis helped explain the secession crisis. They found no conflict between that position and demeaning African Americans through appropriating their culture and bodies upon the blackface minstrel stage. This tradition carried on during the war, when some white northern urban soldiers shifted from cultural appropriation to outright abuse without seeing any contradiction between those strategies and ending the institution of slavery as a means to destroy the Slave Power.

In fact, shortly after the war, New York newspaper correspondent David Conyngham, in his history of the Irish Brigade of the Army of the Potomac, gave a brief account of how some saw the death of the slaveholding oligarchy as a separate issue from

\footnotetext{
8 "Military Matters," New York Sunday Mercury, January 4, 1863 in Styple, 155.

${ }^{9}$ SOL ID, "Among the Hills and Hollows of Virginia," New York Sunday Mercury, February 28, 1863 in Styple, 171.

${ }^{10}$ D. E. F., "Bottom's Bridge, VA," New York Sunday Mercury, May 26, 1862 in Styple, 96.
} 
freedom for their African American chattel. He explained that "The Irish felt that not only was the safety of the great Republic, the home of their exiled race, at stake, but also that the great principles of democracy were at issue with the aristocratic doctrines of monarchism." The Irish sprang to the defense of their adopted country, but as he explained, they "did not ask whether the colored race were better off as bondsmen or freedmen; he was not going to fight for an abstract idea." ${ }^{11}$

The role of blackface minstrelsy within the camps of primarily northeastern white Union soldiers from urban areas--the soldiers most familiar with minstrel culture--shows how some soldiers used antebellum popular culture in order to render a strange and alien land and people familiar and deflect any radical implications of the war. As historian Edward L. Ayers has noted, "public and private, economic and political, religious and secular, and military and civilian are deeply connected." He advised that historians should examine the Civil War from a perspective that examines the "intricate interplay of the structural and the ephemeral, the enduring and the emergent." ${ }^{12}$ A close look at minstrel shows within the camps of Union soldiers connects the structural and the ephemeral in order to show how for some troops, the Civil War deepened antebellum racism rather than mitigating or ameliorating it. This process could occur because the Slave Power conspiracy theory provided soldiers a powerful motivation for continuing to fight while allowing them to use their antebellum cultural practices as a strategy of containment.

${ }^{11}$ D. P. Conyngham, The Irish Brigade and Its Campaign: With Some Account of the Corcoran Legion, and Sketches of the Principal Officers (New York: William McSorley \& Co., 1867), 5-6.

${ }^{12}$ Edward L. Ayers, "What Caused the Civil War," in What Caused the Civil War: Reflections on the South and Southern History (New York: W. W. Norton, 2005), 135, 143. 
The phenomenon of minstrel shows within Union camps has been on the margins of the literatures on common soldiers during the Civil War and scholarship on the blackface minstrel show. For the most part, those who have investigated blackface minstrelsy have stayed away from Union camps. Scholars of minstrelsy and literature have, on the whole, missed the popularity of minstrel shows within soldier camps. Robert C. Toll, in his comprehensive study of the minstrel show, concentrated on how minstrel troupes in the North interpreted the Civil War. Likewise, a recent study by Michael O'Malley contrasted responses to the appearance of greenback currency during the war with minstrel depictions of black soldiers fighting in Union armies. He found that both debates expressed the "contradictory desires at the heart of American culture...for selftransformation" and "the desire for fixed values and an unshakeable 'natural' order." Eric Lott, in his influential interpretation of minstrelsy, Love and Theft, found the minstrel shows enabled white works to create ways in which they could remake themselves while finding way to foreclose the same opportunities to African Americans. Other scholars of the minstrel show, including David R. Roediger and Alexander Saxton, saw the entertainment as responding to needs of white urban workers who found their social and economic position threatened in a rapidly industrializing world. Saxton, in particular, found that the shows reinforced the idea that "the bearers of true patriotism...were honest workingmen who battled to save the Union." Melinda Lawson, while finding that in the decades preceding the Civil War, images of enslaved African Americans as victims came to replace images of them as rebels, dealt only with the antebellum years. ${ }^{13}$ These

\footnotetext{
${ }^{13}$ Robert C. Toll, Blacking Up: The Minstrel Show in Nineteenth-Century America (New York: Oxford University Press, 1974); Michael O'Malley, "Rags, Blacking, and Paper Soldiers: Money and Race in the
} 
approaches, while doing much to establish the importance of blackface minstrel show culture, do little to examine how some soldiers from northeastern urban areas put it to use during the Civil War.

On the other hand, scholars who have studied Union soldiers during the Civil War era have said precious little about minstrel shows. ${ }^{14}$ The exception remains David A. Cecere, who examined the racial attitudes of New England soldiers and found that "the force of daily encounters with...blacks eroded and modified Yankees' two-dimensional

Civil War," in The Cultural Turn in U.S. History: Past, Present, and Future, edited by James W. Cook, Lawrence B. Glickman, and Michael O'Malley (Chicago: University of Chicago Press, 2008), 115; Eric Lott, Love and Theft: Blackface Minstrelsy and the American Working Class (New York: Oxford University Press, 1993), 236-37; David R. Roediger, The Wages of Whiteness: Race and the Making of the American Working Class, New Edition, with an introduction by Kathleen Cleaver (New York: Verso, 2007); and Alexander Saxton, "Blackface Minstrelsy," in Inside the Minstrel Mask: Readings in Nineteenth-Century Blackface Minstrelsy, edited by Annemarie Bean, James V. Hatch, and Brooks McNamara (Hanover, NH: Wesleyan University Press, 1996), 81; Melinda Lawson, "Imagining Slavery: Representations of the Peculiar Institution on the Northern Stage, 1776-1860," in The Journal of the Civil War Era 1, no. 1 (March 2011).

${ }^{14}$ Studies by Joseph Allan Frank, Chandra Manning. James McPherson, Reid Mitchell, and James I.

Robertson, Jr. do not mention minstrelsy as a form of entertainment among the troops, even though they all, to varying degrees, consider how soldiers interpreted race and slavery during the Civil War era; Joseph Allan Frank, With Ballot and Bayonet: The Political Socialization of American Civil War Soldiers (Athens: University of George Press, 1998); Chandra Manning, What This Cruel War Was Over: Soldiers, Slavery, and the Civil War (New York: Knopf, 2007); James M. McPherson, For Cause and Comrades: Why Men Fought in the Civil War (New York: Oxford University Press, 1997); Reid Mitchell, Civil War Soldiers (New York: Viking, 1988); and James I. Robertson, Jr., Soldiers Blue and Gray (Columbia: University of South Carolina Press, 1988). 
racial notions," including those derived from the minstrel show. ${ }^{15}$ Cecere showed how for some, contact with African Americans could overturn antebellum stereotypes, but devotes far less attention to how the opposite might occur in the field.

Soldiers evinced a broad familiarity with minstrelsy. Bell Irvin Wiley and Mark E. Neely, Jr. have both shown that soldiers often sought out minstrel shows for entertainment while on leave or passing through large cities with minstrel troupes. ${ }^{16}$ The experience of Hermon Clarke, a soldier from Oneida in the 117th New York Infantry Regiment, was fairly typical. When he passed through New York City on his way to Washington, D.C., he attended a handful of minstrel shows. ${ }^{17}$ Ample evidence exists that soldiers knew a wide repertoire of minstrel tunes. The officers of the 23rd Massachusetts Infantry Regiment, upon discovering that "our unmusical New Englanders found difficulty in memorizing the bugle-calls," substituted a variety of more recognizable

\footnotetext{
${ }^{15}$ David A. Cecere, "Carrying the Home Front to War: Soldiers, Race, and New England Culture During the Civil War," in Union Soldiers and the Northern Home Front: Wartime Experiences, Postwar Adjustments, edited by Paul A. Cimbala and Randall M. Miller (New York: Fordham University Press, 2002), 323.

${ }^{16}$ Bell Irvin Wiley, The Life of Billy Yank: The Common Soldier of the Union (Indianapolis: Bobbs-Merrill, 1952), 176-77 and Mark E. Neely, Jr., The Boundaries of American Political Culture in the Civil War Era (Chapel Hill: University of North Carolina Press, 2005), 122.

${ }^{17}$ Harry F. Jackson and Thomas E. O'Donnell, Back Home in Oneida: Hermon Clarke and His Letters (Syracuse: Syracuse University Press, 1965), 127-29.
} 
popular tunes for the proscribed calls, including the minstrel show mainstays "Old Dan Tucker" and "Wait for the Wagon."18

But minstrel culture permeated the army in more direct ways. Soldiers, rather than passively consuming minstrel entertainment when available, went to great lengths to produce the shows as well as watch them. Blackface minstrel shows pervaded Union camps among regiments drawn from the urban areas of the East, such as New York City, Boston, and Philadelphia, as well as from the urban areas of the Great Lakes region such as Chicago and Buffalo. In short, soldiers familiar with blackface minstrel culture enacted the entertainments while at war. Regiments with formal minstrel troupes included the Chicago Mercantile Artillery Battery (Board of Trade Battery), 7th Connecticut Infantry Regiment, the 21st Massachusetts Infantry Regiment, the 44th Massachusetts Infantry Regiment, the 9th New York Infantry Regiment (Hawkins Zouaves), the 40th (Mozart) New York Infantry Regiment, the 50th New York Engineer Regiment, the 14th Brooklyn Infantry Regiment (14th New York State Militia Regiment/84th New York Infantry Regiment), the 90th New York Infantry Regiment, the 165th New York Infantry Regiment, the 29th Pennsylvania Infantry Regiment, and the 3rd Rhode Island Heavy Artillery Regiment. ${ }^{19}$ The 148th Pennsylvania Infantry Regiment "organized a minstrel

\footnotetext{
${ }^{18}$ James A. Emmerson, A Record of the Twenty-Third Regiment Mass. Vol. Infantry in the War of the Rebellion 1861-1865 with Alphabetical Roster, Company Rolls; Portraits; Maps; Etc. (Boston: William Ware, 1886), 40-41.

19 "The Civil War Diary of Florison D. Pitts," edited by Leo M. Kaiser, Mid-America: An Historical Review Volume 40: Number 1 (January 1958), 61; "CONN. 7th MINSTREL TROUPE," New Haven Daily Palladium (New Haven: Connecticut), August 26, 1863, Issue 205, Page 1, Column B; From Ashby to Andersonville: The Civil War Diary and Personal Reminiscences of Private George A. Hitchcock, 21st
} 
troupe...but, before we had rehearsed sufficiently for a performance, we received marching orders." ${ }^{20}$ Officers, captured and held at Richmond's notorious Libby Prison, also formed a minstrel troupe and put on blackface performances. ${ }^{21}$

Massachusetts Infantry Regiment, edited by Ronald Watson (Campbell, California: Savas Publishing Company, 1997), 99; Corporal [pseudonym for Zenas T. Haines], Letters from the Forty-Fourth Regiment M.V.M.: A Record of the Experience of a Nine Months' Regiment in the Department of North Carolina in 1862-3 (Boston: Herald Job Office, 1863), 62; J. H. E. Whitney, The Hawkins Zouaves: (Ninth N.Y.V.) Their Battles and Marches (New York: The Author, 1866), 111; Fred C. Floyd, History of the Fortieth (Mozart) Regiment New York Volunteers, which was Composed of Four Companies from New York, Four Companies from Massachusetts, and Two Companies from Pennsylvania (Boston: F. H. Gilson, 1909), 6667; Theodore Lyman Diary Entry, March 4, 1865, in Meade's Army: The Private Notebooks of Lt. Col. Theodore Lyman, edited by David W. Lowe (Kent: Kent State University Press, 2007), 338-39; J. J., "Fourteenth Regiment N.Y.S.M.," April 4, 1864 in Styple, 248; Henry Warren Howe diary entry, in Passages from the Life of Henry Warren Howe, 58; Nemo, "Department of the Gulf," New York Times March 9, 1863, Page 1, Column 2; "From Savannah," Chicago Tribune, January 20, 1865; and Frederic Denison, Shot and Shell: The Third Rhode Island Heavy Artillery Regiment in the Rebellion, 1861-1865 (Providence: Third R.I.H. Art. Vet. Association, 1879), 129.

${ }^{20}$ J. W. Muffly, editor, The Story of Our Regiment: A History of the 148th Pennsylvania Vols. (Des Moines: Kenyon Printing \& Mf. Co., 1904), 327.

${ }^{21}$ George N. Bliss, Prison Life of Lieut. James M. Fales (Providence: N. Bangs Williams, 1882), 12-13; J. W. Chamberlain, "Scenes in Libby Prison," in Sketches of War History 1861-1865: Papers Read Before the Ohio Commandery of the Military Order of the Loyal Legion of the United States 1886-1888, Volume II (Cincinnati: Robert Clarke, 1888), 353-54; Albert Heffley Diary Entries October 17, November 4, November 11, November 19, and November 26, 1863 in Civil War Diaries of Capt. Albert Heffley and Lt. Cyrus P. Heffley (Apollo, PA: Closson Press, 2000), 64, 66, 67, 68, 69; Lucius D. Hinckley, "A Few Months in Rebel Prison," in War Papers: Being Papers Read Before the Commandery of the State of Wisconsin Military Order of the Loyal Legion of the United States (Milwaukee: n.p., 1903), 444; William 
The extent to which soldiers went to replicate the blackface minstrel show in the field demonstrates its cultural importance to them. For urban soldiers, the entertainment lay not so much in the show itself as in recreating the entirety of the experience, from the costumes to the theater setting. They took the participatory nature of the minstrel show-where audiences were expected to cheer and help produce the general atmosphere in the theater--to its logical end, where production and consumption united. In the field, soldiers "blacked up," the central facet of the minstrel show. While soldiers could easily acquire grease, burnt cork, or ash in the camps to serve as their make-up, other accoutrements proved far more difficult for them to find. The members of the 9th New York Infantry Regiment (Hawkins Zouaves), stationed on relatively remote Roanoke Island, North Carolina, had trouble "procuring curled" hair while organizing their minstrel troupe in early 1862. Upset at not having wigs for their show, the problem "almost brought them to the verge of despair." Instead of putting on the performance without the wigs, they then proceeded to engage in a series of deceptive practices designed to coerce the raw material out of the local African American population. They tried many different means to acquire what they termed "long wool." First the troops sent out "missionaries" who preached "the

B. McCreery, My Experiences as a Prisoner of War, and Escape from Libby Prison: A Paper Read Before the Commandery of the State of Michigan, Loyal Legion of the U.S. (Detroit: Winn \& Hammond, 1893), 14;Warren Hewitt Mead, "Southern Military Prisons and Escapes," in Glimpses of the Nation's Struggle: Third Series: Papers Read Before the Minnesota Commandery of the Military Order of the Loyal Legion of the United States, 1889-1892 (St. Paul: D.D. Merrill Company, 1893), 219; George H. Starr, "In and Out of Confederate Prisons," in Personal Recollections of the War of the Rebellion: Addresses Delivered Before the Commandery of the State of New York, Military Order of the Loyal Legion of the United States, Second Series (New York: G.P. Putnam's Sons, 1897), 77. 
gospel of cleanliness and neatness; but every exhortation ended with advice against wearing of long hair." Some men shaved their own heads in an attempt to "induce the darkies to sacrifice some of their wool for the benefit of the histrionic art." 22

These initial strategies failed the members of the 9th New York, who then took the tack of telling the blacks around camp "that they could never successfully aspire to be soldiers while they wore long hair; that all soldiers wore their hair short, therefore, if they wished to be soldiers they must do likewise." Meeting once again with failure, the Union troops decided to use force to attain the material for wigs. As a member of the regiment recalled: "the negroes who were the owners of the kind of head covering coveted, were kidnapped, carried to a squad-room, kept quiet by dire threats, their wool deftly and swiftly removed by a Zouave armed with a pair of shears, and the shorn victims sent on their way as bald as babies." ${ }^{23}$ In this instance, instead of only appropriating African American culture as entertainment for whites, the soldiers appropriated actual African Americans. That the Zouaves of the 9th New York Infantry Regiment spent vast effort cajoling and badgering the local population, and ultimately kidnapping it, helps reveal how much importance urban soldiers placed on the costumes of the minstrel show. Just as urban soldiers took their costumes seriously, they placed great emphasis on practicing their performance. Bugler Florison D. Pitts of the Chicago Mercantile Board of Trade Artillery Battery noted spending more than a week preparing "for a nigger show" and reported "we have had quite a number of rehearsals, and the thing goes

\footnotetext{
${ }^{22}$ Matthew J. Graham, The Ninth Regiment New York Volunteers (Hawkins Zouaves): Being the History of the Regiment and Veteran Association from 1860 to 1900 (New York: E.P. Corby \& Co., 1900), 198-99. ${ }^{23}$ Ibid.
} 
off pretty well." Pitt's show impressed visitors and proved to be quite popular. Following the matinee in a packed theater, General Francis Herron invited the soldiers to put on an encore performance for himself and his staff. He "expressed himself highly pleased with the music," and the initial successes led to several more shows. ${ }^{24}$ Other soldier troupes impressed observers, as well. A reporter for the New York Times watched a performance by the 3rd Rhode Island Heavy Artillery Regiment and remarked, with some surprise, that "here we have all the popular negro and other melodies of the day, Virginia breakdowns and such like dances, insomuch that one might fancy himself at Christy's or Bryant's, in New-York." ${ }^{25}$ Likewise, a reporter from the New York Herald proclaimed that the show put on by the 14th Brooklyn Infantry Regiment was "highly credible to all concerned." ${ }^{26}$ Theodore Lyman, a staff officer in Meade's entourage, went to "hear...nigger minstrels (all enlisted men)" and decided that "the niggers were really excellent, the speech, by an ancient dark, on the state of the country, was side-splitting."27 Soldiers placed value in a polished performance, which in turn led to acclaim, just like the performers at the minstrel halls back home.

Beyond making sure that they had all necessaries for the performers, soldiers also expended vast amounts of time and effort to recreate the minstrel hall in the field. When possible, soldiers utilized extant buildings for their shows. The men of the 29th Pennsylvania Infantry Regiment occupied a theater in Savannah, Georgia. ${ }^{28}$ Likewise, the

\footnotetext{
${ }^{24}$ Kaiser, "The Civil War Diary of Florison D. Pitts," 61-62.

${ }^{25}$ H. J. W., "Important from Port Royal," New York Times, January 28, 1863, Page 1, Column 3.

26 "The Army of the Potomac," New York Herald, February 8, 1864, Page 1, Column 1.

27 Theodore Lyman diary entry, March 4, 1865 in Lowe, Meade's Army, 338-39.

28 "From Savannah," Chicago Tribune, January 20, 1865.
} 
14th Brooklyn Infantry Regiment held multiple performances at the Culpeper Academy of Music in occupied Virginia. ${ }^{29}$ The 3rd Rhode Island Heavy Artillery Regiment used a hall at the local commissary depot. ${ }^{30}$ In short, soldiers put on their performances in whatever large buildings they could find, preferably ones that had served as theaters or music halls previously.

When soldiers could not find buildings large enough to accommodate their performers and audiences, they built them. While stationary in camps, regiments would construct massive performance halls that attempted to replicate urban venues as closely as possible. The 40th New York Infantry Regiment erected a theater, complete with afterdark illumination provided by "gas made on the grounds, by a manufacturing appliance, from the refuse fat and bones that were gathered each day at the cook houses." The walls for the building stood a full fifteen feet tall; the interior sported a stage, benches, and

\footnotetext{
${ }^{29}$ History of the Fighting Fourteenth (n.p.: n.p., 1911), 109. It is possible that Walt Whitman, the famed American poet and author, took in a show at this theater. Whitman wrote to his mother that "There is more fun around here than you would think for--I told you about the theatre the 14th Brooklyn has got up, they have songs \& burlesques \&c, some of the performers real good." It is possible that one of the "performances" he saw was the 14th Brooklyn's blackface minstrel troupe; Walt Whitman to Louisa Van Velsor Whitman, February 12, 1864, in Walt Whitman, The Correspondence: Volume I: 1842-1867, edited by Edwin Haviland Miller (New York: New York University Press, 1961), 198. Other soldiers commented on the 14th Brooklyn's "theatrical entertainment" in Culpeper; Jacob J. Zorn diary entry, February 8, 1864 in A Sergeant's Story: Civil War Diary of Jacob J. Zorn 1862-1865, edited by Barbara M. Croner (Apollo, PA: Closson Press, 1999), 97.

${ }^{30}$ H. J. W., "Important from Port Royal," New York Times, January 28, 1863, Page 1, Column 3.
} 
even a balcony for officers, their wives, and assorted visiting dignitaries. ${ }^{31}$ A soldier who saw this structure commented in amazement at the "splendid scenery" with "every thing in regular style." He seemed awed with the "small Gas works to light it up." ${ }^{32}$ Most famously, the 50th New York Engineers built behind the Union lines at Petersburg a hall with a twelve-by-twelve stage and a multi-story steeple from pine logs. While religious services were held inside on Sundays, minstrel shows played every other night of the week. A staff officer judged the structure "a masterpiece of rustic architecture," and it was likely one of the largest semi-permanent edifices built by the Army of the Potomac. ${ }^{33}$ Besides the balconies and lightings, soldiers decorated stages with painted backdrops, just as in the professional minstrel shows.

Even within the harsh conditions of Libby Prison, the amateur minstrel troupe gathered, as best they could, all the elements of a professional troupe. Beyond the burnt cork used for the blackface, soldiers secured "apparel for the performers who took the ladies' parts" from Confederate guards. They also bought instruments from outside the walls of the prison and had programs printed to advertise the shows. Their show attracted "prison officials who took an interest in this amusement and furnished materials for

\footnotetext{
${ }^{31}$ Daniel Cooledge Fletcher, Reminiscences of California and the Civil War (Ayer: Press of Huntley S. Turner, 1894), 127 and Floyd, History of the Fortieth (Mozart) Regiment New York Volunteers, 109. ${ }^{32}$ Leo W. Faller to Parents, March 31, 1861 in Dear Folks at Home: The Civil War Letters of Leo W. and John I. Faller with an Account of Andersonville, edited by Milton E. Flower (Carlisle: Cumberland County Historical Society and Hamilton Library Association, 1963), 64.

${ }^{33}$ W. J. George, "Church Built at Petersburg by Engineers During Civil War," Professional Memoirs Corps of Engineers, United States Army and Engineer Department at Large, Volume 4 (1912), 521 and Theodore Lyman Diary Entry, March 4, 1865, in Lowe, Meade's Army, 338-39.
} 
costumes, stage curtains, and other purposes." ${ }^{34}$ A soldier who observed the shows thought the "Evening entertainment by Bogus darkeys good." 35

The minstrel shows emerged as a grassroots popular entertainment in the camp. Soldiers put on the minstrel shows primarily for themselves, but officers often attended the spectacle. Some generals encouraged performances. Brig. Gen. John H. H. Ward sponsored an "Ethiopian Concert" for the entertainment of his division and the remainder of the Third Corps of the Army of the Potomac in March $1863 .{ }^{36}$ Brig. Gen. H. Judson Kilpatrick "erected a pretty little theatre in the village of Stevensburgh" in early 1864, in which the first week of performances were "devoted to lovers of negro minstrelsy," with performers drawn from the ranks of the cavalry corps of the Army of the Potomac. ${ }^{37}$ When Maj. Gen. George Gordon Meade's son Spencer and two friends visited Meade's headquarters at the Army of the Potomac's encampment in March 1864, they went over to "one of the neighboring camps, where the soldiers" had "a negro minstrel exhibition."38

\footnotetext{
${ }^{34}$ Chamberlain, "Scenes in Libby Prison," 353-54; Starr, "In and Out of Confederate Prisons," 77; Mead, "Southern Military Prisons and Escapes," 219; and Bliss, Prison Life of Lieut. James M. Fales, 12-13.

${ }^{35}$ Albert Heffley Diary Entry, November 11, 1863 in War Diaries of Capt. Albert Heffley and Lt. Cyrus P. Heffley, 67.

${ }^{36}$ Life of David Bell Birney, Major-General United States Volunteers (Philadelphia: King \& Baird, 1867), 119.

37 "Fifth Regiment, New York (Ira Harris) Cavalry," February 17, 1864 in Styple, Writing and Fighting the Civil War, 242.

${ }^{38}$ [George Gordon Meade to Mrs. George G. Meade], March 26, 1864 in The Life and Letters of George Gordon Meade, Major-General United States Army, Volume II, edited by George Gordon Meade (New York: Charles Scribner's Sons, 1913), 183.
} 
Blackface minstrelsy filled a variety of antebellum cultural spaces, and it filled those same spaces during the Civil War. Most germane, in varying degrees minstrelsy laid out a set of racial stereotypes that provided urban workers a sense of community and belonging in a rapidly changing world and allowed for a veiled critique of oppressive social and political power structures. The comic and burlesque characters played by white performers--and widely known by audiences as intensified and dramatic depictions of African Americans rather than an authentic representation of them--also contributed to a sense of security among audiences. No matter how bad their own lives seemed, they could compare themselves favorably to the slapstick antics of Jim Crow. By the Civil War, minstrelsy had secured its place in Northern popular culture as a genre with mutable characteristics united by white performers in blackface, comic routines, and musical numbers purporting to be African songs from the South. The lack of any uniform or standard overt ideological message accounts for the popularity of the form. By avoiding a particular partisan message, actors attracted the widest audiences, who in turn enjoyed freedom to explore their own lives through the medium. These practices could exist quite comfortably within the Slave Power conspiracy theory, as it provided little comment on the enslaved African Americans themselves. Rather than explaining how the Union would be redefined after the Civil War, it presented the conflict as a return to first principles. With the perversions of the slaveholding oligarchy swept away, the nation could return to the "true" republicanism that the founders had intended. Thus, some soldiers from the urban northeast could enact their antebellum conceptions of their place in the Union without considering that the Civil War might change them. 
Although blackface minstrelsy began in the 1820s as an almost exclusively working-class entertainment, where immigrant urban workers could tweak their own bosses surreptitiously through the antics of Jim Crow or buffoonery of Jim Dandy, by the outbreak of the Civil War the genre had become popular culture. The increasing standardization of the genre, the growth of permanent rather than itinerant minstrel troops, and advertising in newspapers helped shear any implicit political slant from the performances. ${ }^{39}$ As scholar Robert C. Toll has noted, "minstrelsy was the first example of the way American popular culture would exploit and manipulate Afro-Americans and their culture to please and benefit white Americans." Blackface minstrelsy gained popularity because the shows addressed a broad range of anxieties that common white people in the United States faced in the 1820s. Burgeoning industrialization and increasing urbanization led to the loss of traditional folk culture, particularly among immigrants. Uprooted and unmoored from the cultural practices that had helped them create meaning in their lives, urban workers sought "to establish new definitions of themselves as Americans and to find new 'rules' to govern and explain their situation." Popular culture--most acutely the blackface minstrel show--aided these people in their

\footnotetext{
${ }^{39}$ Mark E. Neely, Jr., criticizes those who wish to see blackface minstrelsy as the popular culture wing of the Democratic Party in the decades immediately preceding the Civil War. He sees the genre as a form of entertainment particularly popular in urban settings, thus leading some to draw a relationship of causation between the Democratic Party, which was also popular in Northern urban areas, and the blackface minstrel show. For interpretations that tightly align blackface minstrelsy with the Democratic Party in the North, see Baker, Affairs of Party, 212-58 and Alexander Saxton, The Rise and Fall of the White Republic: Class Politics and Mass Culture in Nineteenth-Century America (New York: Verso, 1990), 165-82. Neely, The Boundaries of American Political Culture in the Civil War Era, 97-127.
} 
effort to do so. As Toll has argued powerfully, the emergence of a modern, capitalistic America necessitated "cultural forms that reflected the average man's nationalism and egalitarianism" and also necessitated the cultural productions that "could replace rural folk culture with symbols that white 'common men' could all unite around." According to him, minstrel shows "became a major vehicle through which Northern whites conceptualized and coped with many of their problems." Historian David C. Roediger has echoed this assessment, noting "that the growing popular sense of whiteness represented a hesitantly emerging consensus holding together a very diverse white working class and that part of that consensus derived from the idea that blackness could be made permanently to embody the preindustrial past that they scorned and missed." 40

Thus, while minstrel shows appropriated African American culture, they also turned those appropriations to their own ends. Audiences could acknowledge their desires for the preindustrial past that was slipping away while simultaneously reassuring themselves that the loss of it remained a good thing. The fact that men enacted this cultural process in the male space of the minstrel hall allowed them to create a new sense of community and create a new form of folk culture--one rooted in the production and consumption of white popular culture, unhindered by prior ethnic and national identities-peculiarly suited to their present circumstances. The minstrel show remained preoccupied with addressing the concerns of its white audiences rather than defining the precise nature of blacks. Audiences used the impenetrable black of the minstrel mask as a place to project their own anxieties and desires.

${ }^{40}$ Toll, Blacking Up, 51, 5, 33; and Roediger, The Wages of Whiteness, 97. 
William J. Mahar further plumbed the ideological depths surrounding blackface minstrelsy. He argued that "minstrelsy did not create the plantation myth; rather, it participated in the commodification of an escapist notion that forced labor differed little from supervised play" and that "the idea of the plantation never changed, never developed into a 'real' place." Furthermore, "the plantation of minstrelsy's making was essentially a burlesque environment, just as the blackface operas were a domain for fantasized social pleasure." Thus, while blackface minstrelsy played on, and with, racialist stereotypes, it never codified them into a systematic articulation of racist ideology. Audiences enjoyed consuming performances that they considered "authentic," they realized that the performers on stage acted as if they were black. The blackface performance provided "a setting celebrating a sense of conviviality and community that the ever-changing minstrel show audience could imagine as applicable to their own lives...that allowed sentimentality and shallowness to substitute for critical and comic assessments of the human condition." Many modern interpretations of blackface minstrelsy impute a coherent ideological valence, whether in asserting that the minstrel show assisted in creating a working-class consciousness or served as a propaganda arm of the Democratic Party, they often overlook that primary function of minstrelsy as popular entertainment, a nuance that Mahar grasps. Part of the robust popularity of the genre lay in its ability to speak to many different people; it allowed audiences to confront their desires and fears in a safe setting. ${ }^{41}$ As with most forms of popular culture, as the genre

\footnotetext{
${ }^{41}$ William J. Mahar, Behind the Burnt Cork Mask: Early Blackface Minstrelsy and Antebellum Popular Culture (Urbana: University of Illinois Press, 1999), 333-34.
} 
became a way to make money, it appealed to larger and larger sections of the white populace of the North. And while racial prejudices comprised a large part of the minstrel show, the primary function of the blackface performance lay more in addressing the social and cultural needs of its audiences rather than in promulgating an image of what the actual lives of African Americans looked like.

The anxieties that led to the popularity of minstrelsy--the dislocation of traditional communities, the loss of independence, the subjection of rural people to the highly structured and disciplined tempo of urban work rhythms, and the needs for roots in a turbulent society--persisted during military service. In fact, enlisting served to intensify these disorientations. Soldiers on campaign in the South encountered new forms of regimentation in the army, strange landscapes in the South, as well the novel sight of actual African Americans on actual plantations. In response, the soldiers could and did use the repertoire of blackface minstrelsy to interpret the strange sights they saw, as well as reassure themselves that the end of slavery and freedom for millions of enslaved black people would not seriously threaten their status within the Union.

Minstrel culture provided soldiers an idiom on which to base their expectations for black behavior. Yet descriptions left by soldiers and newspaper correspondents hint that some urban northerners had expected blacks in the South to appear far different from the blackface minstrels they had seen at home. Soldiers at the start of the war harbored conceptions, if not outrightly expressed, that actual African Americans culture would diverge greatly from the minstrel show stereotypes. A correspondent for the 9 th New York Infantry Regiment opined of a group of blacks that "if Dan Bryant [a famous blackface performer] could only drop upon them when they are dancing, his fortune 
would be made for sure," which demonstrated that he perceived a gap between the staged performance and African American behavior. ${ }^{42}$ For this correspondent, contact with African Americans drove home the idea that blackface performers on the northern stage had presented a poor representation of what African American behavior actually looked like. Sgt. George M. Turner of the 3rd Rhode Island Artillery Regiment wrote to his cousin that "another item of interest is [black] prayer meetings, which is equal to any Minstrel Concert I ever attended at home. ${ }^{43}$ Henry Warren Howe wrote home in a letter: "It is laughable to see the negroes. They look just like our minstrels on the stage. You don't see any true darkies in the North." ${ }^{44}$ Unlike the anonymous correspondent from the 9th New York Infantry Regiment, Howe thought that the northerner performers gave an authentic performance. But he also pointed towards a gulf in his understanding between African Americans he had met in the North and those he encountered in the South. The ones in the North, in his experience, had somehow been inauthentic, while those in the South were "true darkies."

Two newspapers correspondents revealed that they had understood the blackface minstrel show as a caricature and exaggeration of African American life, intended to amuse white audiences. But when they encountered actual African Americans in the

42 "Ninth Regiment, N.Y.S.V.--Hawkins' Zouaves," March 28, 1862, in Styple, Writing and Fighting the Civil War, 82.

${ }^{43}$ George M. Turner to Cousin, December 15, 1861 in Yankee Correspondence: Civil War Letters Between New England Soldiers and the Home Front, edited by Nina Silber and Mary Beth Stevens (Charlottesville: University Press of Virginia, 1996), 85.

${ }^{44}$ Henry Warren Howe to Dear___ June 15, 1861, in Passages from the Life of Henry Warren Howe, 91. 
South, they found themselves surprised that minstrel shows had not exaggerated at all. H.J.W., a correspondent for the New York Times, visited the contraband camp at Hilton Head, South Carolina, and informed his readers that "male contrabands...realize[ed] in their dresses to an extent I could not have thought possible, the extravagant caricatures of CHRISTY'S or BRYANT'S minstrels...[T]he younger ones, arrayed in the second-hand clothing of the officers or civilians who employ them as servants, wore a very ludicrous appearance." ${ }^{45}$ Another correspondent for the New York Times also expressed his surprise upon meeting blacks in the South for the first time: "Until I saw and conversed with the greater number of these persons I believed that the appearance and intelligence of Southern field hands was greatly libeled by the delineators of negro character at the concert saloons. Now I cannot but acknowledge that instead of gross exaggerations the 'minstrels' give representations that are faithful to nature. There were the same grotesque dresses, awkward figures, and immense brogans which are to be seen every night at BRYANT'S or CHRISTY'S. ${ }^{46}$ Contact with African Americans in the South had shifted the view of these correspondents, and some soldiers, from finding the blackface minstrel show as something that "libeled...negro character" or was an "extravagant caricature" to an understanding the northern blackface shows gave "representations that are faithful to nature."

\footnotetext{
${ }^{45}$ H.J.W., "The Negro in South Carolina. Social, Religious and Military Aspects of the Negro Question at Port Royal," July 19, 1862, New York Times, page 2, column 1.

46 "A Visit to Beaufort--The Town in the Hands of the Negroes--The Whites Stampeded in Panic--Slaves Pouring into Union Camps--The Return Home of the Bienville," November 13, 1861, The New York Times, page 3 .
} 
The fact that soldiers described black people along the lines of blackface minstrel reveals that they had, in fact, expected them to differ from the "delineators of negro" culture on northern stages. If soldiers had truly believed Bryant's and Christy's Minstrels as faithful representations of actual blacks, they would have had expressed little surprise when the African Americans they encountered resembled them. This insight indicates that northern audiences, at least on some level, knew that minstrel performances represented something other than a straightforward, authentic depiction of African Americans. In short, the prejudices that minstrel performers both instilled and responded to in northern audiences had not yet been naturalized at the start of the Civil War. The space in audiences' imaginations allowed that the lives of blacks might not necessarily hew to the interpretations presented on the stage.

These points also recall George Fredrickson's descriptions of antebellum proslavery ethnology and romantic racialism. According to these theories, blacks constituted a separate race, as exemplified by their "natural" habitats in tropical regions such as Africa, the Caribbean, and the American South. ${ }^{47}$ These pseudo-scientific theories dictated that any black that a northerner encountered in the North possessed an inauthentic blackness; someone or something could only present an authentic example if within its own "natural" environment. So while blacks in the North suffered widespread abuse at the hands of white mobs, their very presence in the North prevented them from articulating the "true" sense of blackness that white ethnographers and scientists assigned to them. The minstrel show presented a comic and exaggerated version of "authentic"

\footnotetext{
${ }^{47}$ George M. Fredrickson, The Black Image in the White Mind: The Debate on Afro-American Character and Destiny, 1817-1914 ([1971] Wesleyan: Wesleyan University Press, 1987), 145-46.
} 
blackness--albeit one that served as a blank slate on which whites could project their fears and desires--for the amusement of audiences rather than an interpretation that audiences accepted as "authentic" blackness. So, when soldiers encountered blacks in the South, they drew upon the prejudices of the minstrel show with the crucial change that they could compare their preconceptions and ideas of what blacks might be like with actual blacks. When soldiers described African Americans, they did so with the authority of a traveler or explorer; instead of seeing the "What-is-it" in Barnum's Museum, they saw blacks in their "natural" habitat. Most of these urban soldiers and observers decided that their preconceptions of blacks derived from minstrel shows, surprisingly, captured reality.

The phenomenon of blackface minstrel shows within the Union camps also highlights the importance of context. The minstrel shows came about because of three overlapping factors: (1) urban soldiers with the entertainment served in the South; (2) those soldiers had to have much free time while in a sedentary camp; and (3) those soldiers had to come into contact with large numbers of African Americans. The regiments that put on the minstrel shows early in the war all served along the littoral of the Carolinas; after brief fights on the Sea Islands in South Carolina or Roanoke Island in North Carolina, they settled in for a long period of garrison duty. These regiments carried the entertainment with them when they transferred to the main theater in the East, carrying the shows to Army of the Potomac.

Once soldiers had decided that African Americans closely resembled the blackface performers after all, the stage had been set for white troops to see the South as a burlesque environment fully populated with African Americans who could serve as 
entertainment for the white troops. The strategy of containment that had developed in the minstrel halls of the North spread to the field. The stereotypes and prejudices of the minstrel show underwent a consolidation during the war, as soldiers turned from enacting minstrel shows themselves to forcing blacks to perform for them. While northern minstrel shows had functioned on a symbolic and abstract level, urban soldiers began to affix race to actual black bodies in the South and naturalize the stereotypes they had learned from the minstrel show. After deciding that blacks, with their unusual and unfamiliar behaviors and mannerisms, appeared as blackface performers depicted them, soldiers began to see blacks as objects present to entertain them. Blacks often served as the butt of cruel jokes, pranks, and other tortures that soldiers inflicted upon them. Like attendance at minstrel shows, the efforts to force African Americans to conform to the minstrel template extended from officers to the men in the ranks.

Brig. Gen. Nelson A. Miles kept "several comical coons who were as merry as the bumble bee in honeysuckle, to sing and dance for the amusement of himself and staff at his headquarters." He would also have these blacks perform for important visitors who came to camp, accompanied by the regimental band of the 148th Pennsylvania Infantry Regiment. ${ }^{48}$ Beyond these performances, Miles's demands that blacks perform for him sometimes revealed the power that he held and the use of violence that underpinned soldiers' efforts to force blacks to entertain them. Lt. Col. Stephen Minot Weld of the 56th Massachusetts Infantry Regiment, a visitor to Miles's headquarters, related one occasion when forty contrabands arrived at Miles's tent near the end of the war. Weld recalled that "General Miles ordered the band out, and told the negroes that he would

\footnotetext{
${ }^{48}$ Muffly, The Story of Our Regiment, 326-27.
} 
hang everyone who would not dance. About seven refused to dance, saying they were church members. The rest went at it tooth and nail, gray-headed old men and young boys." Rather than recognizing shared humanity or expressing sympathy for the African Americans who had fled their plantations at great personal risk, Weld instead wrote of how he had "never laughed so hard in my life." 49 Presumably Miles refrained from carrying out his threat, but his actions showed how soldiers often went from passive observers of African Americans to active participants, forcing black people to perform for them.

Rather than simply expressing the frustrations that white urban soldiers felt during the war, these cruelties reinforced the color line and drew upon the heritage of the minstrel show by robbing African Americans of their humanity and reducing them to entertainment in the eyes of some whites. Very little separated soldiers abusing blacks and shaving their heads in order to put on a minstrel show from soldiers assaulting African Americans in horrific ways in order to create a similar spectacle that they found amusing. For instance, Pvt. Edward King Wightman of the 9th New York Infantry Regiment wrote home of how "the boys, feeling frisky, amused themselves by tossing the niggers of the regiment, great and small, in a blanket. The darkies were asserted to be getting rebellious and to need admonition. One after another they were dragged from their hiding places and sent heave[n]ward with tremendous forces... Their despairing yells contrasted strangely with the imperturbable, solemn 'one-two-three' of their

\footnotetext{
${ }^{49}$ Stephen Minot Weld to Hannah, April 24, 1865 in War Diary and Letters of Stephen Minot Weld 1861 1865 (n.p.: Riverside Press, 1912), 397.
} 
tormentors...It was confoundedly mean, but I laughed my self double at it...Such vaulting and summer-setting [sic] one would go far to see." ${ }^{50}$

The 5th New York Infantry Regiment routinely abused contrabands escaping into their lines likewise, so much so that they began referring to the practice by the nickname of "the Union drill." ${ }^{51}$ Another soldier, George Turner, gleefully described the nightly entertainment at his camp: "us soldier boys have a great deal of sport with these contrabands, and nearly every night after we have had our supper, we get a crowd of them together and they sing and dance until our sides are nearly bursting with laughter and then to draw the exercise to a close an empty barrel is brought before the audiance [sic], we then offer one of the niggers five cents, to butt the head in with his wooly pate, no sooner is the offer made than some one of them accepts, and lets fly his head at the barrel head, and in goes barrel head, nigger head, and half his body. Then goes up a shout of laughter. ${ }^{52}$ Capt. Evan Woodward of the 2nd Pennsylvania Reserves Infantry Regiment (31st Pennsylvania Infantry Regiment) described how "negroes involuntarily broke forth into a dance, clapping their hands and singing" after hearing his regiment's band commence playing. Unfortunately for the African Americans, their activities attracted Union soldiers to the scene who then proceeded to abuse them. Union soldiers goaded the blacks into "a grand butting match" with "their heads crushing together like

\footnotetext{
${ }^{50}$ Edward K. Wightman to Bro[ther], November 1, 1862, in From Antietam to Fort Fisher: The Civil War Letters of Edward King Wightman, 1862-1865, edited by Edward G. Longacre (Rutherford: Fairleigh Dickinson University Press, 1986), 71.

${ }^{51}$ Alfred Davenport, Camp and Field Life of the Fifth New York Volunteer Infantry (Duryee Zouaves) (New York: Dick and Fitzgerald, 1879), 130-31.

${ }^{52}$ George M. Turner to Cousin, December 15, 1861 in Yankee Correspondence, 85.
} 
rocks, but producing no effects upon them. After scrambling for a few handfuls of pennies thrown among them, they left for their homes, happy with their afternoon's sport." 53

Sgt. James Porter of the 76th Pennsylvania Infantry Regiment recalled a similar activity soldiers forced blacks to perform at Christmastime: "A tube with about six inches of white meal was brought out and a silver half-dollar was placed in the bottom. The darkies, with their hands tied behind their backs, were required to root for the coin. They would plunge their snoots in the meal and root until out of breath. Then the appearance of the silver searcher when he came to the surface to snort furnished the fun. You might not think a little thing like that very funny but try it and see; we enjoyed it immensely. Neither of these darkies won the prize, but in view of the fun furnished they were each presented with a half-dollar." ${ }^{54}$

In the majority of these examples, urban Union soldiers exercised cruelty against blacks in order to provide themselves with spectacle and amusement. The occasional account also suggested an element of social discipline--entertainment combined with the "admonition" to blacks that they were unequal and could be abused by soldiers without consequences. Still other examples recall how audiences at Northern minstrels shows both consumed and produced the entertainment at the same time through their

\footnotetext{
${ }^{53}$ E. M. Woodward, Our Campaigns; or the Marches, Bivouacs, Battles, Incidents of Camp Life and History of Our Regiment [2nd Pennsylvania Reserves] During Its Three Years Term of Service (Philadelphia: John E. Potter, 1865), 94.

${ }^{54}$ 76th Regiment Pennsylvania Volunteer Infantry Keystone Zouaves: The Personal Recollections 1861 1865 of Sergeant John A. Porter Company "B," edited by James A. Chisman (Wilmington, North Carolina: Broadfoot Publishing, 1988), 29.
} 
participation and cheering at the blackface performers on stage. Furthermore, the humor soldiers had origins in the perception that blacks felt no pain. ${ }^{55}$ For instance, the "butting match" amused the soldiers because they believed the black felt "no effects" from the collisions. ${ }^{56}$

Soldiers also coerced blacks to provide them with entertainment without the use of force or explicit threats to use it. Capt. Henry Warren Howe of the 30th Massachusetts Infantry Regiment wrote home in the summer of 1861 that "there were five negroes in our mess room last night, we got them to sing and dance! Great times." ${ }^{57}$ Similarly, D. L. Day a noncommissioned officer of the 25th Massachusetts Infantry described what he called a plantation dance. After the men had eaten dinner, the soldiers would gather scrub brush and wood for bonfires, gather between 200 and 300 soldiers in a ring, and then have 30 to 40 contrabands gather in the middle of the circle. The soldiers then "set them to dancing." Day thought that "they seemed to enjoy the fun as much as the spectators...It was a great sport to watch the antics they cut up trying to dance." ${ }^{58}$ Surgeon J. A. Mowris of the 117 th New York Infantry Regiment recalled a contraband in camp named Joe, "a

\footnotetext{
${ }^{55}$ For short discussions of how white medical professionals thought of African Americans as different, see Jim Downs, Sick from Freedom: African American Illness and Suffering During the Civil War and Reconstruction (Oxford: Oxford University Press, 2012), 34-36. For a brief discussion of how many whites considered blacks to be immune to pain because they were thought to be brutes, see Margaret Humphreys, Intensely Human: The Health of the Black Soldier in the American Civil War (Baltimore: The Johns Hopkins University Press, 2008), 23-24.

${ }^{56}$ Woodward, Our Campaigns, 94.

${ }^{57}$ Henry Warren How to Dear___ June 19, 1861, in Life of Henry Warren Howe, 93.

${ }^{58}$ D. L. Day, My Diary of Rambles with the 25th Mass. Volunteer Infantry, with Burnside's Coast Division; 18th Army Corps; and Army of the James (Milford, Massachusetts: King \& Billings, 1884), 71-72.
} 
genuine specimen of the genus Virginia 'dark.' Though in the service of one officer, his irresistible comicalities were as unconfinable as his essential fragrance, and, were therefore, property of his regiment. His childlike simplicity, apparent credulity and inimitable expressions of wonder at the true or over-drawn accounts of Yankee customs, rendered him an attractive object, to the victims of dull care." Mowris concluded that "in view of the proverb 'a merry heart doeth good like medicine' Joe seems entitled to this reference because of his influence as a sanitary agent." ${ }^{59}$ With this assessment, Mowris showed how the appropriation of black culture for the entertainment of white soldiers worked. Rather than speculate on any of the reasons why Joe might prefer employment by the Union soldiers to enslavement by white southerners, Mowris saw him as "an attractive object," despite his "essential fragrance," because he provided much needed entertainment.

Other urban soldiers described the entertainment and glee they derived from what they saw as the antics of the African American population. John Billings, author of the classic memoir of Union soldier life Hardtack and Coffee, commented on the roles soldiers assigned blacks in the camps. He described how every regiment included musically talented soldiers who would gather to play for entertainment. He described how, typically, "the usual medley of comic songs and negro melodies composed the greater part of the entertainment, and, if the space admitted, a jig or clog dance was stepped out on hard-tack box or other platform." He recalled that "sometimes a real negro

\footnotetext{
${ }^{59}$ J. A. Mowris, A History of the One Hundred Seventeenth Regiment, N.Y. Volunteers (Fourth Oneida) from Date of Its Organization, August 1862, Till That of Its Muster Out, June, 1865 (Hartford, Connecticut: Case, Lockwood, and Company, 1866), 51.
} 
was brought in to enliven the occasion by patting and dancing 'Juba,' or singing his quaint music." Billings noted that "the men played tricks of all descriptions on [African Americans], descending at times to the most shameful abuse...there were a few soldiers who were not satisfied to play a reasonable practical joke, but most bear all that the goodnatured Ethiopian could stand." ${ }^{60}$ Another soldier recalled that "guard duty around the camp [in Louisiana], and especially at picket posts, was always enlivened by ludicrous scenes, in which the 'colored pussun' formed the chief actor." Beyond laughing at African Americans in camp, the soldiers would also watch "the jig-dance, often accompanied by the banjo." Such a performance "would keep a company splitting with laughter, at the expense of a few pennies. The weird plantation songs, in all their purity of Negro dialect and emphasis, would be wafted upon the air of every pleasant evening. The guffaws of 'Sambo,' and also of 'Dinah' were scarcely out of hearing, while the camp was full of these people." ${ }^{61}$ Although these soldiers wrote in retrospect, undoubtedly tinged with nostalgia, the sentiments they expressed comport with contemporary evidence and attitudes.

Soldiers also visited contraband camps to gain amusement through observation of the formerly enslaved African Americans. They gravitated toward what they saw as the spectacle of black social gatherings, expecting an experience akin to the minstrel show. One member of the 9th New York Infantry Regiment (Hawkins Zouaves) described the camp adjacent to his own on Roanoke Island in North Carolina. In a letter published in

\footnotetext{
${ }^{60}$ John D. Billings, Hardtack and Coffee: Or, The Unwritten Story of Army Life (Boston: George M. Smith, 1887), 70.

${ }^{61}$ D. H. Hanaburgh, History of the One Hundred and Twenty-Eighth Regiment, New York Volunteers (U.S. Infantry) in the Late Civil War (Pokeepsie [sic]: n.p., 1894), 18.
} 
the New York Sunday Mercury, he described the "'meetin', as they call it; and such lungs as some of them got! You can hear them easy three miles." ${ }^{62}$ Capt. Joseph E. Fiske of the 43rd Massachusetts Infantry Regiment described his visit "to [a] nigger dance," writing home: "I tell you 'twas the most ridiculous affair, but the darkies really kept good time and danced well." ${ }^{63}$ Another New Yorker explained, "one of the chief amusements, among the soldiers, was in visiting negro dances, and prayer meetings. The last of these are the most singular and impressive sights imaginable, consisting of weird songs, incoherent irreverent shouts, mingled with violent contortion, wails and moans, quaint prayers and responses." ${ }^{64}$ One Massachusetts soldier compared his visit to a black church to a carnival: "the circus began...the whole audience would be shouting, dancing, and working itself into a fine frenzy...The ludicrous actions were too much for my [sensibilities] and I vowed to keep away from them in the future on the Sabbath." ${ }^{65}$ The black prayer meeting provided Northern soldiers with a sight that they found hilarious and comedic because it seemed to comport with the minstrel show. Rather than seeing a sincere expression of African American religious faith, they saw an amusing performance. Here, too, soldiers found more evidence that supported their conflation of the minstrel spectacle with African American life in the South.

\footnotetext{
62 "Roanoke," letter dated March 28, 1862, in Styple, Writing and Fighting the Civil War, 81.

${ }^{63}$ Joseph E. Fiske to Parents, December 8, 1862, in War Letters of Capt. Joseph E. Fiske [Harvard, '61]:

Written to His Parents During the War of the Rebellion from Andover Theological Seminary and Encampments in North Carolina and from South Prisons (Wellesley: The Magnus Press, n.d.), 18.

${ }^{64}$ Harris Beecher, History of the 114th Regiment N.Y.S.V. Where It Went, What It Saw, and What It Did (Norwich: J.F. Hubbard, Jr., 1866), 114-15.

${ }^{65}$ Watson, From Ashby to Andersonville, 102.
} 
When soldiers could not avail themselves of what they found amusing spectacles, they created them. On long marches, for instance, soldiers would observe blacks and sometimes force them to provide entertainment in order to raise morale. Adjutant John Mead Gould of the 29th Maine Infantry Regiment wrote in his diary of an incident that occurred during a taxing march in Louisiana: "One of the laughable incidents of the march are [sic] the actions of the negroes. They are always very ready to talk, laugh and make their obeisance to the boys but when our bands happen to strike up it sets them to dancing. Now to see a great black negress weighing 250 pounds, more or less, and between 30 to 40 years old dance a jig, is no mean sight. As we passed by a plantation today the 47th Pennsylvania struck up some lively tune and instantly the elderly colored ladies who had up to that remained quiet and dignified commenced tossing their heads and hands in the air and shuffling their feet at each other till the whole Brigade was in an uproar. One old darky in particular flew round like a drunken woman and I couldn't help thinking how she was contributing her mite [sic] to crush the rebellion inasmuch as she kept up the spirit of the boys and made their days march more interesting." ${ }^{66}$ As Gould told the story, the blacks lining the road, presumably seeking freedom with the advancing Union columns, aided the Union troops not by withholding their labor from their masters but only by making the "march more interesting." He also presented the nature of blacks as immoderate and comical; beneath a "quiet and dignified" façade, African Americans concealed true natures such as that of "drunken women." Another soldier, also writing of service in Louisiana, described the "amusing spectacle of nine miles of negroes" that he

\footnotetext{
${ }^{66}$ John Mead Gould diary entry for March 17, 1864 in The Civil War Journals of John Mead Gould 18611865, edited by William B. Jordan (Baltimore: Butternut and Blue, 1997), 312.
} 
witnessed. ${ }^{67}$ These accounts, then, revealed a set of implicit views of what he thought blacks to be like; these views owed much to the stereotypes presented by the minstrel show, and yet another instance of soldiers seeing the "natural" environment of blacks as a gigantic burlesque.

An inversion of the social order constructed by the minstrel show tradition could elicit immediate violence. On August 6, 1863 Edward King Wightman told his parents about an incident that occurred earlier in the week on the docks in Portsmouth, Virginia. Soldiers, waiting for supplies to be loaded onto their transports, acquired liquor and became drunk. As Wightman related, "if there is any one thing the 9th Regiment agree in as a principle, it is that niggers were born to be abused, and 'licking a nigger' they count as the climax of a drunken spree." He continued; "As luck would have it, our contraband Aaron made himself so forward, laughing at their eccentric performances, that he attracted their attention, and a couple of them, highly incensed, scaled the boxes on which he was perched and assaulted him with bayonets." Wightman managed to interrupt the assault, but eventually Aaron fell off of the boxes and to the ground, where "unluckily for the poor darkey, a dozen Zouaves below were yelling and like hungry sharks waiting to seize him. They jumped on him and kicked him until he was nearly dead, and...laid open his thick lips with a gash a half an inch in breadth, breaking off a couple of teeth besides." Other soldiers who tried to intervene suffered injury as well; "A Corporal of the 3rd...was knocked down and hit over the bridge of the nose with a bayonet." The assailants also knocked down "a herculean contraband belonging to" Lt. Col. Francis X.

${ }^{67}$ Beecher, History of the 114th Regiment N.Y.S.V., 185. 
Meyer of the 117th New York Infantry Regiment. For good measure they "threaten[ed] to 'lick' the officer himself." ${ }^{68}$

In the Aaron incident, the Zouaves had been the comic performers. The soldiers, staggering and reeling about drunk, gave an "eccentric performance," a spectacle that Aaron found entertaining. When he unwisely laughed at them, he made clear that the Zouaves had become the object of entertainment for an African American. He had inverted the logic of the minstrel show. For the Zouaves, their violence righted the situation. Their similar responses to the other contrabands and Union officers reinforced the cultural logic of the minstrel show; it was their prerogative and right to their entertainment.

In sum, urban white Northern soldiers turned to blackface minstrelsy at the start of the war. The reinforcement of the stereotypes found in the blackface performance helped blind soldiers to the ways in which African Americans diverged from the popular representation of them. For these soldiers, contact with African Americans deepened their prejudices. Rather than seeing African Americans as full people with a range of desires, motivations, and dreams, soldiers often appropriated them as objects of amusement. They believed that the "natural" environment of black people was the burlesque. Their attitudes evinced little progressive shift by the end of the war.

Two days after Robert E. Lee surrendered the Army of Northern Virginia at Appomattox Court House on April 9, 1865, elements of the Army of the Potomac had begun the journey back to Washington. General Meade and his headquarters retinue had removed to the sleepy hamlet of Farmville, Virginia. One of his staff officers, Theodore

\footnotetext{
${ }^{68}$ Edward King Wightman to Parents, August 6, 1863 in Longacre, From Antietam to Fort Fisher, 147-48.
} 
Lyman, thought the "place... like Warrenton [Virginia] in look, but not so well built or large." The Union troops there found comfortable lodgings in the "large brick hotel on the main street." As the Federal officers relaxed for the evening, they turned to their usual entertainments. Namely, "the indomitable Spaulding [colonel of the 50th New York Engineers] had gut up his 'Minstrels' in the great dining hall." As the soldiers relaxed and took in the entertainment, a group of mounted men rode up to the hotel. Confederate cavalry general Fitzhugh Lee led the group, which two days earlier had broken out of the Union encirclement to carry on resistance. Lee and his men, deciding that further struggle served no purpose, had given up the fight and sought Meade's headquarters so that they could surrender. The minstrel show paused, as Lee went up to Meade's room. There, Lee told me "I have come to give myself up. I was Gen. Fitz Hugh Lee; I suppose I am Mr. Lee now!" As the cavalry chieftain tendered his surrender, "the Reb staff went down to hear" the Northern minstrel show. Lyman mused in his diary of the "strange sight in the midst of our officers!"69

Thus it was that even as the Civil War staggered to a close, soldiers reaffirmed their beliefs that African Americans and their culture existed largely to provide comic entertainment for whites. Despite, or perhaps because of, their experience with African American troops Meade's staff enacted a minstrel show in their hour victory. As Lyman noted, the presence of former enemies at the blackface show, rather than the show itself, was the strange sight.

The number of blackface minstrel shows among white urban northern soldiers demonstrates that contact with African Americans intensified and naturalized antebellum

${ }^{69}$ Theodore Lyman diary entry, April 11, 1865 in Lowe, Meade's Army, 372. 
stereotypes of blacks. Even as the war ended, some northerners had embarked upon perpetuating the plantation myth within popular culture through the blackface minstrel show. ${ }^{70}$ And while some have described the assent of the North in the Southern race project during the years of Reconstruction as a sellout of wartime ideals in order to establish postwar fellowship between the whites of the North and South, the lessons soldiers drew from the minstrel show calls into question how invested soldiers became in the project of emancipation. With fleeting encounters with blacks, northern troops could imagine that the minstrel image had been right, after all, and catalogued examples that confirmed their stereotypes.

Some soldiers had imbued their republican institutions with values solidified and refracted through the minstrel shows--the romanticized field hand found on the blackface stage both validated suppressed nostalgia for a rural past while confirming the superiority of the workingman of the North--and then went to war to protect those values. Thus, as both David Roediger and Alexander Saxton have remarked, deeply racist urban whites

\footnotetext{
${ }^{70}$ For the long, uncertain, and contested construction of race and blackness in the South following the Civil War, see, among others David W. Blight, Race and Reunion: The Civil War in American Memory (Cambridge: Belknap Press of Harvard University Press, 2001); Jane Elizabeth Dailey, Before Jim Crow: The Politics of Race in Postemancipation Virginia (Chapel Hill: University of North Carolina Press, 2000); Barbara J. Fields, "Ideology and Race in American History," in Region, Race, and Reconstruction: Essays in Honor of C. Vann Woodward, edited by J. Morgan Kousser and James M. McPherson (New York: Oxford University Press, 1982), 158-169; Glenda Gilmore, Gender and Jim Crow: Women and the Politics of White Supremacy in North Carolina, 1896-1920 (Chapel Hill: University of North Carolina Press, 2000); Ariela J. Gross, What Blood Won't Tell: A History of Race on Trial in America (Cambridge: Harvard University Press, 2008); and Grace Elizabeth Hale, Making Whiteness: The Culture of Segregation in the South, 1890-1940 (New York: Pantheon, 1998).
} 
fought in a war that ultimately resulted in the end of slavery and freedom for millions of enslaved African Americans. The Slave Power thesis was broad enough to encompass such regional innovations; it allowed regional antebellum patterns of culture to flourish. And as the earlier account from David Conyngham has hinted, as the war ended, some soldiers could then draw upon the Slave Power thesis to narrate their complete victory in the war, while leaving aside consideration of the role African Americans played during the role or what their place in the newly reunited nation might be. 


\section{Chapter 4 \\ "To Transmit and Perpetuate the Fruits of This Victory:" Union Regimental Histories and the Slave Power in Immediate Retrospect}

$* * * * * * * * * * * * * * * * * * * *$

At the end of the Civil War, soldiers took stock of the war that had just concluded.

They reflected upon the long hard years of the war and their own experiences. In regimental histories, they argued that the war had been fought to depose a slaveholding oligarchy in the South that had sought to destroy republicanism. Furthermore, because soldiers intended these books to stand as documents for posterity, they explicitly identified the Slave Power as the culprit behind secession more often than they had in wartime letters, when the idea had often been implicit. Also, because these soldiers intended their works to stand the time, they took a broader perspective and sought to connect their struggle into a national narrative. In doing so, they minimized the importance of antebellum regional variations. In short, they employed the Slave Power thesis to explain the Civil War, which demonstrated that the idea had survived the Civil War. The Slave Power thesis also served as a way for soldiers to present a coherent explanation for the cause of the Civil War and avoid speculating too deeply on the place of African Americans in the reunited nation. The idea had been broad enough to encompass multiple regional variations, from Pennyslvania and New Jersey to the West to the urban Northeast, but it also provided a coherent narrative of how a native aristocracy had nearly strangled republicanism. Many soldiers held these tenets as the bedrock of their cause, and when they explained at some length their view of the war, they returned to them.

Historians, in focusing on the vast outpouring of letters generated by Civil War soldiers, have overlooked a crucial body of work that northerners produced shortly after 
the Civil War, the genre of regimental histories. Typifying such sentiment, James M. McPherson dismissed the works because they suffered "from a critical defect: they were written for publication." For McPherson, letters and diaries provide an account of the conflict "far closer to the immediacy of experience than anything the soldiers wrote for publication then or later." ${ }^{1}$ Aaron Sheehan-Dean dubbed regimental histories "simultaneously antiquarian and heroic" and thought that "the narrow focus and celebratory tone" rendered them poor sources through which to study how Civil War soldiers interpreted the war. $^{2}$ While some historians have examined individual regimental histories, few have made a comprehensive survey of the genre. ${ }^{3}$

\footnotetext{
${ }^{1}$ Work that has appeared since McPherson's book has suggested that soldiers wrote letters and diaries with the intent for others to read them. Thus, while a letter might seem more authentic than a published work, soldiers composed their letters and diaries with an eye toward audience, as well. Even letters written in close proximity to the events they describe could exhibit startling shifts and changes in interpretation, as Robert L. Bee has shown; Robert L. Bee, editor, The Boys from Rockville: The Civil War Narratives of Sgt. Benjamin Hurst, Company D, 14th Connecticut Volunteers (Knoxville, Tennessee: University of Tennessee Press, 1998). James M. McPherson, For Cause and Comrades: Why Men Fought in the Civil War (New York: Oxford University Press, 1997), 11.

${ }^{2}$ Aaron Sheehan-Dean, "The Blue and the Gray in Black and White: Assessing the Scholarship on Civil War Soldiers," in The View from the Ground: Experiences of Civil War Soldiers, edited by Aaron SheehanDean (Lexington, KY: University of Kentucky Press, 2007), 10.

${ }^{3}$ See Peter S. Carmichael, "We Respect a Good Soldier, No Matter What Flag He Fought Under: The 15th New Jersey Remembers Spotsylvania," in The Spotsylvania Campaign, edited by Gary W. Gallagher (Chapel Hill: University of North Carolina Press, 1998) and Lesley J. Gordon, "All Who Went into That Battle Were Heroes: Remembering the 16th Regiment Connecticut Volunteers at Antietam," in The Antietam Campaign, edited by Gary W. Gallagher (Chapel Hill: University of North Carolina Press, 1999).
} 
The only historian to make widespread and systematic use of regimental histories to explain soldier experiences was James I. Robertson, in Soldiers Blue and Gray. ${ }^{4}$ Robertson commented that his mentor, Bell I. Wiley, had "bypassed a multitude of printed works such as the vast category of regimental histories" while writing his classic studies The Life of Johnny Reb: The Common Soldier of the Confederacy and the Life of Billy Yank: The Common Soldier of the Union. Robertson aimed "to supplement those works" and covered the same ground that Wiley had--the experiences of soldiers in the field and the granular texture of everyday life with little attention paid to ideological or political sentiments--except he used regimental histories instead of letters and diaries as his primary source of evidence. ${ }^{5}$ As Reid Mitchell wrote of Soldiers Blue and Gray,

\footnotetext{
${ }^{4}$ Historian Stephen Z. Starr attempted a survey of the genre of regimental histories with a brief article in 1964, but he was hampered by the absence of a comprehensive bibliography of Civil War literature, so his conclusions remained provisional at best. Starr extrapolated from the limited available data to arrive at an astronomical figure of a total number of regimental histories. Subsequent historians have followed Starr's lead, using inflated extrapolations without reinvestigating how Starr arrived at his figures. Stephen Z. Starr, "The Grand Old Regiment," Wisconsin Magazine of History Vol. 48 (Autumn 1964) , 22 and A. F. Sperry, History of the 33d Iowa Volunteer Infantry Regiment, 1863-6, edited by Gregory J. W. Urwin and Cathy Kunzinger Urwin ([1866] Fayetteville: University of Arkansas Press, 1999), xix.

${ }^{5}$ James I. Robertson, Jr., Soldiers Blue and Gray (Columbia: University of South Carolina Press, 1988), vii-viii. See also: Bell Irvin Wiley, The Life of Johnny Reb: The Common Soldier of the Confederacy (Indianapolis: Bobbs-Merrill, 1943) and Bell Irvin Wiley, The Life of Billy Yank: The Common Soldier of the Union (Indianapolis: Bobbs-Merrill, 1952).
} 
Robertson "studiously avoided tough questions--and new ones." ${ }^{6}$ Because Robertson eschewed investigation into how soldiers perceived the causes and meanings of the war in favor of recounting their daily lives, it reinforced the opinion that regimental histories lacked value to those concerned with ideology, soldier motivation, or social history. Only recently have scholars such as Gary W. Gallagher begun to look at regimental histories as useful sources. ${ }^{7}$

In 1865 and 1866, Union soldiers produced 51 regimental histories, ranging in length for fifty pages to several hundred, a fact sometimes overlooked by historians. ${ }^{8}$ Out of these 51 histories, 27 appeared in 1865 and 24 in $1866 .{ }^{9}$ These numbers represented an

${ }^{6}$ Reid Mitchell, "Not the General but the Soldier: The Study of Civil War Soldiers," in Writing the Civil War: The Quest to Understand, edited by James M. McPherson and William J. Cooper, Jr. (Columbia: University of South Carolina Press, 1998), 86.

${ }^{7}$ Gary W. Gallagher, The Union War (Cambridge: Harvard University Press, 2011), 65-70.

${ }^{8}$ Both Gerald Linderman and David Blight discuss the glut of material authored by soldiers starting in the 1880s. Linderman argues that beyond a brief surge of popular interested in the wake of the Civil War, soldier literature took until the 1880 s to flourish because soldiers, traumatized by the war, needed time to come to grips with their experiences before publishing on it. Blight sees the flowering of Civil War literature in the same decades as resulting from a reconciliationist impulse to reunite both the (white) North and (white) South at the expense of African Americans. Literature dealing with the war took nostalgic, romantic, and sentimental tones, which the American public in turn purchased. Gerald Linderman, Embattled Courage: The Experience of Combat in the American Civil War (New York: Free Press, 1987), 268-279 and David W. Blight, Race and Reunion: The Civil War in American Memory (Cambridge: Belknap Press of Harvard University Press, 2001), 211-299.

${ }^{9}$ I define regimental history as a work containing at least 25 pages of narrative in addition to any roster that appears in the work. It had to appear alone, rather than as a constituent part of a larger work. A regimental history also had to declare itself as such, thereby discounting personal reminiscences and memoirs. I 
efflorescence of the genre, as between 1863 until 1921, the average year saw the publication of only 9 regimental histories. ${ }^{10}$ These works provide a valuable insight into what soldiers thought about the Civil War as it was concluding, but before the political struggles of the Reconstruction era.

Taken as a genre, the regimental histories that appeared in immediate retrospect of the Civil War revealed much about how soldiers thought of themselves and the broader meaning of the conflict. Regimental histories served as form of collaborative commemoration that sought to convey the service and sacrifices of the soldiers to their home communities and thereby knit the two back together again. Overwhelmingly, the regimental histories portrayed the soldiers' interpretation of the Civil War as an untroubled exhibition of patriotic duty and a mission accomplished. Insofar as the works touched upon the causes and outcomes of the Civil War, they pointed to a nefarious slave power as bringing the cataclysm upon the nation and emancipation as a wartime necessity as a way to carve the oligarchic cancer from the body politic. While some regimental histories gave weight to an interpretation of the war as a freedom struggle for African Americans, the broad consensus in their pages pointed more to an understanding of the war as the shattering of the slave power. Because soldiers narrated their own stories and

compiled the list of regimental histories from Charles Dornbusch, Military Bibliography of the Civil War, 3 volumes (New York: New York Public Library, 1961-1972) and Silas Felton, Military Bibliography of the Civil War: Volume IV, Revised (Dayton: Morningside Books, 2003).

${ }^{10}$ Peter C. Luebke, '"To Transmit and Perpetuate the Fruits of This Victory:' Union Regimental Histories, 1865-1866, and the Meaning of the Great Rebellion," Master's Thesis, University of Virginia (2007), 16$17,53$. 
struggles, when African Americans appeared in their books they served as comic relief or tertiary players in the Civil War.

Precisely what should concern the historian regarding these particular regimental histories is that they were written for publication. Soldiers understood that their families constituted the immediate audience for these books, but they also knew that future generations of historians would turn to them for the soldiers' story of the Civil War. They wrote with one eye on the war that had just ended but with the other eye of how others would remember them. They also wrote in the vein of popular antebellum history, which by the time of the Civil War had come to embrace objectivity. Rather than simply a chronicle of heroic actions and self-congratulation, authors sought to pen an accurate account of the war. Crucially, these works also appeared before the political conflicts of Reconstruction. In short, regimental histories provide a snapshot of how soldiers saw their war as it ended, just before the cusp of Reconstruction. But, to properly assess regimental histories, the context surrounding their authorship, production, and intended audience needs investigation.

The authors of regimental histories saw their works as objects of parochial print, which is, written for local objectives. The regimental history served as a supplement to the vast outpouring of print during the war and immediately after that looked at generals, politicians, and the strategy of the war. As historian Alice Fahs has pointed out, northern authors and publishers produced a number of "keepsakes that provided a 'permanent' history of the war" that enlarged upon the "immediate, urgent, disposable" newspaper accounts that came out during the war itself. Focusing on dramatic narrative and commercial value, these books demonstrated "an intense interest in the war that could be 
expressed through possessing a history of it." Regimental histories offered a "keepsake" of the war, but one written on the intensely local level that devoted attention to individual communities through their regiments. The regimental history also offered a granular and personal narrative of the war; it gave readers a micro-level picture of what their community had done in the war to go alongside macro-level accounts of politicians in Washington and the generals in the field. Despite the focus on the individual, regimental historians remained preoccupied with writing an objective and impartial history. ${ }^{11}$

Authors of regimental histories published in 1865 and 1866 presented a broad cross-section of the regiment. Out of the 51 histories, chaplains penned 12 of them, followed closely by privates, who wrote $10 .^{12}$

\begin{tabular}{|r|c|r|}
\hline Author's Rank & \# of Histories & As \% of total \\
\hline Private & 10 & $20 \%$ \\
\hline Corporal & 2 & $4 \%$ \\
\hline Sergeant & 4 & $8 \%$ \\
\hline Lieutenant & 4 & $8 \%$ \\
\hline Captain & 2 & $5 \%$ \\
\hline Regimental Staff & 6 & $12 \%$ \\
\hline Surgeon & 2 & $4 \%$ \\
\hline Chaplain & 12 & $24 \%$ \\
\hline Major & 4 & $8 \%$ \\
\hline Colonel & 2 & \\
\hline
\end{tabular}

\footnotetext{
${ }^{11}$ Alice Fahs, The Imagined Civil War: Popular Literature of the North \& South, 1861-1865 (Chapel Hill: University of North Carolina Press, 2001), 288, 310.

${ }^{12}$ Percentages for the chart are rounded.
} 


\begin{tabular}{|l|c|c|}
\hline Other/Unknown & 3 & $6 \%$ \\
\hline Total & & \\
\hline
\end{tabular}

Although individual authors penned regimental histories, the works emerged as collaborations among the soldiers of regiments. Rather than representing individual viewpoints, the works aspired to present a small-scale history of the war rooted in the authority of personal experience. ${ }^{13}$ But because the personal experiences extended beyond the observation and experiences of any individual, authors took a number of steps in order to tell the story of the regiment rather than the individual.

Recognizing the momentous events they participated in, regimental historians began preparations to write their histories before the war even ended. Col. W. W. H. Davis, in the preface to his history of the 104th Pennsylvania Infantry Regiment, described how "when I re-entered military service, in the fall of 1861 , I became possessed of two hobbies; one, that of writing the history of my regiment, and the other, to have a monument erected to the memory of those might fall in action, or die of wounds or disease." ${ }^{14}$ Here, Davis linked both of his "hobbies" to the commemoration of the service of the regiment; one would mark its service in the written record of the nation, while the other would mark the physical landscape. Chaplain Moses D. Gage of the 12th

\footnotetext{
${ }^{13}$ For a discussion of how nineteenth century Americans saw personal experience as the measure of authority, see Ann Fabian, The Unvarnished Truth: Personal Narratives in Nineteenth-Century America (Berkeley: University of California Press, 2000).

${ }^{14}$ William W. H. Davis, History of the 104th Pennsylvania Regiment, from August 22nd, 1861, to September 30th, 1864 (Philadelphia: Jas. B. Rodgers, 1866), viii.
} 
Indiana Infantry Regiment began his work "at the urgent solicitation of the officers and men of the Regiment, whose service it records." 15

Writers also took care to collect materials to give their accounts more authority than if they had authored it alone. Surgeon Harris Beecher of the 114th New York Infantry Regiment used "extensive journals and memoranda kept by the author throughout his service" and "the journals and memoranda of others, which in the main have been corroborative of each other, or at least have enabled him to arrive at more correct results." Beecher also utilized the files of soldier correspondence that had been published in local newspapers as aids. ${ }^{16}$ Others used headquarter records and other official reports, such as Sgt. Henry Davidson of the 1 st Ohio Light Artillery. ${ }^{17}$ Similarly, Pvt. Lyman Pierce of the 2nd Iowa Cavalry Regiment explained that he consulted notes "taken upon the march, at the time the incidents recorded transpired" and later compared

\footnotetext{
${ }^{15}$ Moses D. Gage, From Vicksburg to Raleigh; or, a Complete History of the Twelfth Regiment Indiana Volunteer Infantry, and the Campaigns of Grant and Sherman, with an Outline of the Great Rebellion (Chicago: Clarke \& Co, 1865), v.

${ }^{16}$ Harris Beecher, History of the 114th Regiment, N.Y.S.V. Where it Went, What it Saw, and What it Did (Norwich: J.F. Hubbard, Jr., 1866), i-ii. Other regimental historians made extensive use of contemporary newspaper correspondence from soldiers in crafting their narratives. See: Stephen Fleharty, Our Regiment, a History of the 102d Illinois Infantry Volunteers, With Sketches of the Atlanta Campaign, the Georgia Raid, and the Campaign of the Carolinas (Chicago: Brewster \& Hanscom, 1865), 5; William L. Hyde, History of the One Hundred and Twelfth Regiment N.Y. Volunteers (Fredonia: W. McKinstry \& co., 1866), vi; and Amos Judson, History of the Eighty-Third Regiment Pennsylvania Volunteers, edited by James A. Trulock and Alice Rains Trulock ([1865]Arlington: Stonewall House, 1985), unpaginated introduction.

${ }^{17}$ Henry M. Davidson, History of Battery A, First Regiment Ohio Vol. Light Artillery (Milwaukee: Daily Wisconsin Print House, 1865), iii.
} 
those notes "with those taken by others, and the official reports [emphasis in the original]." ${ }^{18}$

In several instance, authors submitted their manuscripts to peer review, having other soldiers look over the materials and contribute to the work. Sgt. John Kinnear of the 86th Illinois Infantry Regiment met with his colonel, Allen Fahnestock, to discuss the work. He also noted that "General [David] Magee, Major [J. F.] Thomas, Dr. [I. J.] Guth, Captain [S. L.] Zinser, and others at Peoria... examined [the manuscript] before publication." ${ }^{19}$ Pierce of the 2 nd Iowa Cavalry crowed that the book had been inspected "by Gen. [Edward] Hatch... and the field officers of the Second Iowa cavalry, all who have attested to its correctness; hence we claim for our book a degree of anthenticity [sic] which no historian, not a participant in the events he records, can attain." 20

While soldiers sought to write accurate and authoritative works, they realized that the audience for the regimental history remained the soldiers themselves and their families. During the Civil War, regiments were organized by state, and many times came from the same part of the same state. Historian Gerald J. Prokopowicz has argued that "the soldiers' loyalty centered on the smallest units to which they belonged...especially the regiment." He explained that "the regiment, more than any other unit, was a selfaware community, held together by bonds based on common geographic, social, cultural,

\footnotetext{
${ }^{18}$ Lyman B. Pierce, History of the Second Iowa Cavalry, Containing a Detailed Account of Its Organization, Marches, and Battles in Which it has Participated; also, a Complete Roster of Each Company (Burlington, Iowa: Hawk-Eye Printing Establishment, 1865), iii.

${ }^{19}$ John R. Kinnear, History of the Eighty-Sixth Regiment Illinois Volunteer Infantry, During Its Term of Service (Chicago: Tribune Company's Book and Job Printing Office, 1866), v.

${ }^{20}$ Pierce, History of the Second Iowa Cavalry, v.
} 
or economic identities, strengthened by months of training and campaigning as a unit."21 In telling their war stories, soldiers not only spoke of their own experiences during the war but by extension what the home communities had experienced. The regimental history provided a momento for the soldier and the home front.

Two instances provide examples that soldiers wrote mainly for their own community. Maj. W. H. Chamberlin of the 81st Ohio Infantry Regiment told his readers that "the design of producing this little work originated in the belief that such a record, in a permanent form, would be acceptable to the living as a memento of their suffering and services in the War of the Rebellion, and that it might also serve as a slight tribute to the memory of those gallant and heroic members of our Regiment who have laid their lives upon their Country's altar."22 Henry Davidson, likewise, avowed "no desire to gather laurels as an author. If the narrative is sufficiently readable to preserve fresh memories of each other in the bosoms of my comrades in arms,--memories of the struggles, hardships, and dangers to which they were exposed in defence of the glorious flag of our united country,--my feeble efforts will have been amply rewarded." ${ }^{23}$ Both Chamberlin and Davidson pointed out that the regimental histories documented and commemorated the experiences during the war.

Three more instances demonstrate that soldiers saw the regimental history as a way to tie the soldiers back into the communities from which they had come. Chaplain

\footnotetext{
${ }^{21}$ Gerald J. Prokopowicz, All for the Regiment: The Army of the Ohio, 1861-1862 (Chapel Hill: University of North Carolina Press, 2001), 4-5.

${ }^{22}$ William H. Chamberlin, History of the Eighty-First Regiment Ohio Infantry Volunteers, During the War of the Rebellion (Cincinnati: Gazette Steam-Printing House, 1865), 3.

${ }^{23}$ Davidson, History of Battery A, iii.
} 
William H. Rogers of the 189th New York Infantry Regiment "hoped any member of the command will find each historical sentence a text from which he may entertain his children and grand-children with stories of his soldier-deeds and sufferings which may otherwise have fallen into oblivion." ${ }^{24}$ Adjutant Joshua H. Horton and Capt. Solomon Teverbaugh, the writers of a history of the 11th Ohio Infantry Regiment, included "several pages of good paper, neatly ruled" at the back of their book. Because the "book [was] intended as a 'keepsake' in the families of the members of the Regiment," the authors bound in extra "paper in orderd that a fuller record of " each member's service might be ensured. They directed that "wherever possible, this should be done by the hand of him who was a soldier, thus preserving the record in the handwriting of the soldier himself. It will be but a few years at best until all who took part in putting down the late gigantic rebellion will have passed away." ${ }^{25}$ Lt. James Clark of the 115 th New York Infantry regiment dedicated his volume to "To the widows, children, fathers, mothers, brothers, sisters, friends, and surviving comrades of the brave men who left the pleasures and comforts of home, enlisted in the $115^{\text {th }}$ Regiment, and have gone down to untimely graves while serving their country." 26

\footnotetext{
${ }^{24}$ William H. Rogers, History of the One Hundred and Eighty-Ninth Regiment of New-York Volunteers (New York: John A. Gray \& Green, 1865), 5.

${ }^{25}$ Joshua H. Horton and Solomon Teverbaugh, History of the Eleventh Regiment (Ohio Volunteer Infantry), Containing the Military Record, So Far as it is Possible to Obtain it, of each Officer and Enlisted Man in the Command, a List of Deaths, an Account of the Veterans, Incidents of Field and Camp, Names of Three Months' Volunteers, Compiled from the Official Records (Dayton: W.J. Shuey, 1866), 121.

${ }^{26}$ James H. Clark, The Iron Hearted Regiment: Being an Account of the Battles, Marches and Gallant Deeds Performed by the 115th Regiment N.Y. Vols., Also a List of the Dead and Wounded, an Account of
} 
Several aspects of the printing of the regimental histories themselves and the size of their print run also point to soldiers writing for a parochial audience. The soldiers themselves published the regimental histories; that is, they took the burden of financing the printing. The printers colophons on the regimental histories of 1865 and 1866 point toward the local printers or the job printing houses often appended to newspaper publishers rather than commercial publishers in the urban East. As with most other books and print media during the Civil War era, regimental histories circulated on entirely local networks. ${ }^{27}$ And the numbers of any individual regimental history printed numbered only in the hundreds. Henry Davidson's history had a small edition of 250 copies. ${ }^{28}$ Horton and Teverbaugh "printed but a limited number" of their volume because it would be of "little interest to any but the members of and immediate friends of the regiment." ${ }^{29}$

Hundreds of Brave Men Shot on a Score of Hard Fought Fields of Strife, a Complete Statement of Harper's Ferry Surrender, Sketches of the Officers, a History of the Flags and those who Bore Them, Together with Touching Incidents, Thrilling Adventures, Amusing Scenes, Etc., Etc., Etc. (Albany: J. Munsell, 1865), iii. ${ }^{27}$ While regimental histories continued after the 1880 s to circulate within local networks, the larger book trade underwent a consolidation from the local to the national by the 1880 s due to changes in technology, distribution networks, methods of distribution, and the establishment of a national market. See: Michael Winship, "Manufacturing and Book Production" in A History of the Book in American: Volume 3: The Industrial Book, 1840-1880, edited by Scott E. Casper, Jeffrey D. Groves, and Michael Winship (Chapel Hill: University of North Carolina Press, 2007), 40-69; and Michael Winship, "The National Book Trade System: Part 1: Distribution and the Trade," in ibid., 117-130.

${ }^{28}$ Davidson, History of Battery A, 3.

${ }^{29}$ Horton and Teverbaugh, History of the Eleventh Regiment (Ohio Volunteer Infantry), xv. 


\section{Chaplain Louis N. Beaudry of the 5th New York Cavalry Regiment took up a}

subscription in the camp, and recorded in his diary "subscriptions for 388 books." 30

Despite the parochial authorship, production, and audience, the soldiers wrote

with a larger awareness that their works would be used as future sources for historians. As Eileen Ka-May Cheng has perceptively pointed out, antebellum historians such as

${ }^{30}$ Louis N. Beaudry, War Journal of Louis N. Beaudry, Fifth New York Cavalry: The Diary of a Union Chaplain, Commencing February 16, 1863, edited by Richard E. Beaudry (Jefferson, NC: McFarland, 1996), 232. Beaudry's initial print run was small, but he evidently kept the printing plates and issued subsequent editions with extra material. See Louis N. Boudrye, Historic Records of the Fifth New York Cavalry, First Ira Harris Guard, Its Organization, Marches, Raids, Scouts, Engagements, and General Services during the Rebellion of 1861-1865, with Observations of the Author by the Way, Giving Sketches of the Armies of the Potomac and of the Shenandoah. Also, Interesting Accounts of Prison Life and of the Secret Service. Complete Lists of Its Officers and Men (Albany:, S.R. Gray, 1865); Louis N. Boudrye, Historic Records of the Fifth New York Cavalry, First Ira Harris Guard, Its Organization, Marches, Raids, Scots, Engagements, and General Services during the Rebellion of 1861-1865, with Observations of the Author by the Way, Giving Sketches of the Armies of the Potomac and of the Shenandoah. Also, Interesting Accounts of Prison Life and of the Secret Service. Complete Lists of Its Officers and Men, 2nd Edition (Albany: S.R. Gray, 1865); Louis N. Boudrye, Historic Records of the Fifth New York Cavalry, First Ira Harris Guard, Its Organization, Marches, Raids, Scots, Engagements, and General Services during the Rebellion of 1861-1865, with Observations of the Author by the Way, Giving Sketches of the Armies of the Potomac and of the Shenandoah. Also, Interesting Accounts of Prison Life and of the Secret Service. Complete Lists of Its Officers and Men, 3rd Edition, Enlarged (Albany: J. Munsell, 1868); and Louis N. Boudrye, Historic Records of the Fifth New York Cavalry, First Ira Harris Guard, Its Organization, Marches, Raids, Scots, Engagements, and General Services during the Rebellion of 1861-1865, with Observations of the Author by the Way, Giving Sketches of the Armies of the Potomac and of the Shenandoah. Also, Interesting Accounts of Prison Life and of the Secret Service. Complete Lists of Its Officers and Men, 4th Edition, Enlarged (Albany: J. Munsell, 1874). 
George Bancroft and William Prescott "were responsible for developing the very ideals-impartiality and originality--that was used to marginalize them, as the 'scientific' historians at the turn of the century sought to demonstrate their own commitment to these ideals. ${ }^{31}$ Soldiers, aware of these histories, aspired to provide grist for the future mill. ${ }^{32}$ In a preface to a history of an Ohio regiment, Chaplain T. F. Brown embarked on a lengthy statement of purpose for the book. He asked: "Were the doings of one regiment, among thousands engaged in the war, of such interest as to demand a separate history?" He answered himself, affirmatively of course: "to perpetuate the fruits of this victory we must have records of the war--many records, made from many different points of view, and of many kinds, great and small. Brown thought that regimental histories would "be invaluable to the Bancroft, who fifty years hence, shall write the history of the war." ${ }^{33}$ Union general William T. Sherman, writing to the author of a regimental history, praised

\footnotetext{
${ }^{31}$ Cheng's argument bears comparison with that of Aaron Sheehan-Dean, who argues that regimental histories "reflected all the strengths and weaknesses of history as it was practiced in the mid-nineteenth century," resulting in works of minor interest; Sheehan-Dean, 10. Eileen Ka-May Cheng, The Plain and Noble Garb of Truth: Nationalism and Impartiality in American Historical Writing, 1784-1860 (Athens: University of Georgia Press, 2008), 255.

${ }^{32}$ A summary of the reading within soldier camps, which included historic works and biographies of historical figures, can be found in David Kaser, Books and Libraries in Camp and Battle: The Civil War Experience (Westport, Connecticut: Greenwood Press, 1984), 17, 52, 59.

${ }^{33}$ George L. Wood, The Seventh Regiment [Ohio Infantry], A Record (New York: James Miller, 1865), 5-8.
} 
it and noted that they could "be condensed into histories of great Armies or Campaigns." ${ }^{34}$

These factors taken together--that soldiers composed the regimental histories in groups; that they sought accuracy; that they intended the works as noncommercial products that would knit the community in the field back into the home; that they aspired to write an accurate and objective history in the mold of antebellum historical writing; and that they created a timeless keepsake--explain why regimental histories contained little discussion of partisan politics. Regimental historians aimed to create something true and uncontested. Thus, it becomes all the more important to examine how these authors interpreted the Civil War. Their explanations of the causes of the war, its goals, and how they perceived both black and white Southerners represented what they perceived as a noncontroversial consensus.

Regimental historians, rather than casting the Civil War in immediate retrospect as a moral cause to emancipate enslaved African-Americans, saw the war as a moral cause to shatter the shackles of the slave holding aristocracy. They began their books with exhortations of how a slaveholding oligarchy had pushed the ignorant masses of the South to war. Their experiences with Confederate soldiers, Confederate civilians, the southern towns, and southern landscapes confirmed for them just how baleful the influence of the Slave Power had been. Blaming the Slave Power for the state of the

\footnotetext{
${ }^{34}$ William T. Sherman to Stephen Fleharty, 21 May 1866, in possession of Sarah E. Glass, quoted in Philip J. Reyburn and Terry L. Wilson, editors, "Jottings from Dixie: The Civil War Dispatches of Sergeant Major Stephen F. Fleharty, U.S.A. (Baton Rouge: Louisiana State University Press, 1999), 30.
} 
South also enabled soldiers to excuse the bulk of southern whites for having control over their own condition.

Regimental historians avoided the use of the term Civil War, instead referring to the just concluded conflict as a rebellion. Employment of "rebellion" underscored that the authors saw secession as an illegitimate act of revolt against lawful authority. Harris Beecher of the 114th New York Infantry Regiment alternately called the war "the great American rebellion," "the war of the Rebellion" or "the monster Rebellion." ${ }^{35}$ Moses Gage of the 12th Indiana Infantry also utilized the term "Great Rebellion." ${ }^{36}$ Other writers added placed more emphasis on who the motives of those behind the "Great Rebellion." Lyman Pierce of the 2nd Iowa Cavalry Regiment wrote of the "slave-drivers' rebellion." 37 Thomas Stevenson of the 78th Ohio Infantry Regiment instead used the term "slaveholders' war." 38

Harris Beecher of the 114th New York Infantry Regiment thought that the South should have won the Civil War, for its people were Americans. He noted that the "soldiers of the Southern States, sharing the former pride and haughtiness of our nationality" should have succeeded in their rebellion. He argued that the South had failed to secure independence because "history no where tells us that aristocracy is the parent of a successful revolution." Rather, "it is only when the heart of labor has begun to throb

\footnotetext{
${ }^{35}$ Beecher, History of the 114th Regiment, N.Y.S.V., 11,12, 291.

${ }^{36}$ Gage, From Vicksburg to Raleigh, ix.

${ }^{37}$ Pierce, History of the Second Iowa Cavalry, 9.

${ }^{38}$ Thomas M. Stevenson, History of the 78th Regiment O[hio] V[eteran] V[olunteer] I[nfantry], from Its "Muster-In" to its "Muster-Out," Comprising its Organization, Marches, Campaigns, Battles, and Skirmishes (Zanesville: Hugh Dunne, 1865), v.
} 
under unendurable oppression that thrones are overturned and ministers beheaded." He pointed out that the English Civil War, the French Revolution, and the Reformation all provided examples where the oppressed had prevailed against overweening odds. The "American rebellion," on the other hand "was a revolt of the aristocracy" with "no nobler purpose than the enrichment of the privileged classes, and the still further degradation of the poor." ${ }^{39}$ Beecher's explanation of the Civil War rooted the conflict in a global historical context of the march of democracy; he saw the Civil War as perpetuating this process not because it resulted in the emancipation of millions of enslaved blacks, but because it toppled the aristocracy. ${ }^{40}$

While Beecher's interpretation of the Civil War neglected to mention enslaved African Americans, other soldiers mentioned them freely. But the mention of African Americans usually served to underscore just how an aristocracy had become rooted in the first republican nation in the world. Surgeon James Mowris of the 117th New York Infantry Regiment asserted, "the late war...was nothing more nor less than a conflict between Aristocracy and Republicanism." He saw secession "as the handmaid and champion of a galling social despotism." The "despotism" grew from "slavery, like a deadly Upas planted besides the tree of Liberty." ${ }^{41}$ Moses Gage of the 12th Indiana

\footnotetext{
${ }^{39}$ Beecher, History of the 114th Regiment, N.Y.S.V., 12-15

${ }^{40}$ For a further discussion of the Slave Power thesis within an international context, see Andre M. Fleche, The Revolution of 1861: The American Civil War in the Era of Nationalist Conflict (Chapel Hill: University of North Carolina Press, 2012), 119-26.

${ }^{41}$ James A. Mowris, History of the One Hundred and Seventeenth Regiment N.Y. Volunteers (Fourth Oneida), from its Date of its Organization, August, 1862, till that of its Muster Out, June, 1865 (Hartford: Case, Lockwood, and co., 1866); 191-92, 39-40.
} 
Infantry likewise remarked out that the secessionists had "engage[d] in the Utopian scheme of founding a Southern Confederacy, based upon the declared right of capital to own the labor of a subject African race." ${ }^{42}$ A. W. M. Petty of the 3rd Missouri Cavalry Regiment (Union), who styled his work in the form a diary, entered on a day when nothing had happened: "In the absence of anything else to say at this point, we will remark that the institution of slavery, as it formerly existed in the United States, was an injury to the nation and society." It had created "that insatiable and ungovernable spirit of aristocracy which has for so many years been so prominently manifested by the lords of the southern soil."43

Capt. George Wood of the 7th Ohio Infantry wrote that for thirty years, the indigenous aristocracy of the South had sought to secure a "firmer footing" because "the Federal Government was too democratic." The leaders of the South's "ambition was to have capital control labor, while the laboring classes were to be subservient to the capitalists, and a sort of serfdom forced upon them. The wealthy class were to live in luxury and indolence upon the unrequited toil of their slaves. These facts, the leaders of the wicked rebellion, which they were to inaugurate, were careful to conceal from their followers" Much like Beecher, as well, Wood remarked that "in this strife, like all others where aristocratic privilege comes in contact with the freedom of democracy, these arrogant lords were to meet with bitter disappointment." ${ }^{44}$ William Dodge of the 75 th

\footnotetext{
${ }^{42}$ Gage, From Vicksburg to Raleigh, 15.

${ }^{43}$ A. W. M. Petty, History of the Third Missouri Cavalry from its Organization in Palmyra, Missouri, 1861, up to November Sixth, 1864, with an Appendix and Recapitulation (Little Rock: J. Wm. Denby, 1865), 40.

${ }^{44}$ Wood, The Seventh Regiment, 16-17, 15.
} 
Illinois Infantry Regiment also averred that "our army fought for the maintenance of the Union: the rebel army for its disintegration and the perpetuity of Slavery." ${ }^{45}$ These five writers explicitly named slavery as the prime cause of the Civil War, in so far as it had allowed a southern aristocracy to become ensconced and corrupt the republican experiment.

That regimental historians saw a slaveholding oligarchy at the heart of secession allowed them to express sympathy for the men in the Confederate ranks while condemning those who led them. Time and again, authors demonized Confederate leaders while excusing the men they led. Harris Beecher described General Nathan Bedford Forrest as "a devil incarnate," who drove his men--"wretched victims of the slave aristocracy"--to the slaughter. ${ }^{46}$ James Clark of the 115 th New York Infantry Regiment recalled how Union soldiers encountering captured Confederate generals would "sing out...'They're the chaps who keep up the war; if he was a private we'd have sympathy for him, but he is a leader."' 47 Samuel Hurst of the 73rd Ohio Infantry Regiment mournfully wrote: "It was so sad to look on the windrows of dead, even though they were enemies; for we knew that many had persuaded themselves that they were dying in a noble cause...driven on by reckless and conscienceless leaders...even in

\footnotetext{
${ }^{45}$ William Sumner Dodge, A Waif of the War: or, The History of the Seventy-Fifth Illinois Infantry, Embracing the Entire Campaigns of the Army of the Cumberland (Chicago: Church \& Goodman, 1866),

19.

${ }^{46}$ Beecher, History of the 114th Regiment, N.Y.S.V., 12.

${ }^{47}$ Clark, The Iron Hearted Regiment, 123.
} 
ignoble cause, went to their death unswervingly." ${ }^{48}$ Chaplain Warren Cudworth of the 1st Massachusetts Infantry Regiment recalled how the citizens of the town of Fredericksburg, Virginia "were generally disloyal, having been infected with the sophistry of Gen. Lee-that they must go with their State, without regard to the nation; as though a man owed greater allegiance to one thirty-sixth of a great country, because he happened to be born on its soil, than to the remaining thirty-five thirty-sixths!"49 Osceola Lewis of the 138th Pennsylvania Infantry Regiment refused in his account to name Lee but called him "the wicked idol of a deluded people" who had resorted to arms, "the only support of falsely claimed rights." 50

Soldiers also gleefully recorded the downfall of Confederate leaders. Recounting how his regiment marched past Confederate general William Barksdale's grave, Edwin Houghton of the 17th Maine Infantry Regiment remarked, "Such is the reward of lawless ambition! A United States representative turned traitor to the country, whose laws he had sworn to uphold, and, paying the penalty of treason by death at the hands of United States soldiers, buried in a blanket, with a pasteboard monument erected to his memory!" 51

${ }^{48}$ Samuel Hurst, Journal-History of the Seventy-Third Ohio Volunteer Infantry (Chillicothe: n.p., 1866), $144-45$.

${ }^{49}$ Warren H. Cudworth, History of the First Regiment (Massachusetts Infantry), from the 25th of May, 1861, to the 25th of May, 1864, Including Brief References to the Operations of the Army of the Potomac (Boston: Walker, Fuller, and Company: 1866), 311.

${ }^{50}$ Osceola Lewis, History of the One Hundred and Thirty-Eighth Regiment, Pennsylvania Volunteer Infantry (Norristown: Wills, Iredell, \& Jenkins, 1866), 159-60.

${ }^{51}$ Edwin B. Houghton, The Campaigns of the Seventeenth Maine (Portland, ME: Short \& Loring, 1866), 96. 
Wales Wood of the 95th Illinois Infantry informed his readers how the regiment, while stationed in Alabama immediately after the surrender of the Confederacy, saw disgraced leaders pass by. Wood took great delight in reporting to his readers that "[P.G.T.] Beauregard, [Braxton] Bragg, [Gideon J.] Pillow, Admiral [Raphael] Semmes, and others...return[ed] disappointed and unattended to their homes, where, during the remainder of their lives, they are to experience that ignominy and shame which will ever attach to them as original and persistent traitors." 52

Regimental historians writing in the immediate aftermath of the Civil War in 1865 and 1866 could express with little contradiction a respect and camaraderie with their former enemies. It made sense for Samuel Merrill of the 1st Maine and District of Columbia Cavalry Regiment to believe that "the rank and file of the Rebel army will return to a cordial submission to our laws." He explained; "the leading idea" among defeated Confederates "seemed to be this: The matter of difference between North and South had been submitted to the arbitration of arms. The battle has been a fair one, and we have lost it." ${ }^{53}$ According to George Powers of the 38th Massachusetts Infantry Regiment, "the paroled rebel soldiers, to their credit it be said, were unanimous in denouncing the assassination [of President Abraham Lincoln]; and were determined to allow of no guerilla warfare in the State, now that the main armies had surrendered.

\footnotetext{
${ }^{52}$ Wales W. Wood, A History of the Ninety-Fifth Regiment, Illinois Infantry Volunteers from its Organization in the Fall of 1862 Until its Final Discharge from the United States Service, in 1865 (Chicago: Tribune Company's Book and Job Printing Press, 1865), 186.

${ }^{53}$ Samuel Merrill, The Campaigns of the First Maine and District of Columbia Cavalry (Portland: Bailey and Noyes, 1866), 369.
} 
Perfect good feeling existed between the late belligerents." ${ }^{54}$ Wales Wood related how surrendered Confederates were "perfectly satisfied with the result of the war, and claimed that they had never been in favor of it from the beginning. Many of these soldiers were honest in such assertions, and had been forced into the ranks by that reign of terror which the leading traitors had instituted and carried out to advance their base schemes and sustain their rotten Confederacy." ${ }^{55}$ The sentiments of regimental historians thus contrast with the arguments of historians such as David Blight, who suggest that reconciliation between the North and the South consisted of a process that culminated after fifty years with a "clean narrative of a Civil War between two foes struggling nobly for equally honorable notion of liberty." ${ }^{56}$ The Slave Power thesis allowed soldiers to blame the deposed leaders while excusing the men, for the slaveocracy had deceived its own people as much had it had deceived the North.

The inclination of authors to excuse the men in the Confederate ranks from responsibility for the Civil War extended to southern civilians. Regimental historians looked at white southern civilians and found little to like. They often perceived them as "poor white trash," but instead of seeing the civilians as responsible for their own circumstances they saw it as but another baleful result of the slaveholding oligarchy. The perceptions of southern civilians also fed into northern explanations for why the vast and beautiful land of the South had not been developed or rendered productive. Obviously the

\footnotetext{
${ }^{54}$ George W. Powers, The Story of the Thirty-Eighth Regiment of Massachusetts Volunteers (Cambridge: Dakin and Metcalf, 1866), 206.

${ }^{55}$ Wood, A History of the Ninety-Fifth Regiment, Illinois Infantry Volunteers, 199.

${ }^{56}$ Blight, Race and Reunion, 351.
} 
"poor white trash" lacked the skills or resolve to make the land productive, but that was the fault of the elite.

Regimental historians, most often those who had served in the Deep South or West, commented on the degraded and dirty nature of white Southerners and placed the blame on their leaders, rather than any innate deficiency in the white Southerners themselves. Samuel Hurst of the 73rd Ohio Infantry Regiment thought that Alabama possessed "abundant 'white trash,' which, though not the whitest, was yet the trashiest we had ever seen. They were such wretched, sallow, squalid, ragged and unclean starvelings as only a land of 'chivalry' could produce." ${ }^{57}$ James Mowris unequivocally stated that "a practical Democracy engenders no distinct class of 'poor white trash' groveling in hopeless ignorance over beyond the impassable gulf of social caste." ${ }^{58}$ John Kinnear of the 86th Illinois Infantry Regiment "could not refrain from laughing at their oddity in agricultural pursuits." He found white southerners "sluggish, indolent, and careless in their habits and works." He also described the southern farmers as "a poor ignorant being, who like the parrot, can talk and palaver with simple unmeaningness." 59

The perceived lack of an industrious class beyond the scheming oligarchs gave soldiers an explanation for the lack of towns in the South. The towns soldiers marched through failed to live up to what northern standards. James Clark of the 115th New York Infantry Regiment remarked that "Annapolis is not a pretty town. The streets are narrow and dirty. The buildings, even on the principal squares, are fast going to decay. The once

\footnotetext{
${ }^{57}$ Hurst, Journal-History of the Seventy-Third Ohio Volunteer Infantry, 135-37.

${ }^{58}$ Mowris, History of the One Hundred and Seventeenth Regiment N.Y. Volunteers, 170.

${ }^{59}$ Kinnear, History of the Eighty-Sixth Regiment Illinois Volunteer Infantry, 135-36.
} 
sparkling halls of fashion cease to dazzle with jewels and shine with beauty." ${ }^{60}$ Bostonian Warren Cudworth of the 1st Massachusetts Infantry Regiment found that "Yorktown...like most Virginia settlements, was in a state of dilapidation and decay. Notwithstanding its historical importance, there did not seem to be enterprise enough among its inhabitants to keep it in a neat and respectable condition." 61

Moses Gage opined, "Desolation seemed written upon everything, presenting a striking contrast with the busy scenes in our Northern villages, where industry and enterprise have been stimulated instead of paralyzed by the war. Nothing evinced more clearly the destitute condition of the people than the total absence of all trade, and the dependence of rich and poor alike upon the production of home industry." ${ }^{62}$ The dearth of impressive cities in the South reconfirmed for regimental historians what the Slave Power had wrought.

Authors noted the absence of public education institutions in the South. Because of the lack of education, the Southern masses found themselves susceptible to the blandishments and empty promises of the elite. Mowris of the 117th New York Infantry Regiment explained that "the non-educating policy peculiar to the southern states, subjects the masses to the direction of a few politicians." It was "convenient to the demagogue, but degrading to the people; unprofitable to the State, and signally disastrous to the nation." ${ }^{63}$ Robert C. Eden of the 37th Wisconsin Infantry Regiment pronounced Southern newspapers as "tools of the rebel government...well calculated to deceive the

\footnotetext{
${ }^{60}$ Clark, The Iron Hearted Regiment, 32.

${ }^{61}$ Cudworth, History of the First Regiment (Massachusetts Infantry), 141.

${ }^{62}$ Gage, From Vicksburg to Raleigh, 184.

${ }^{63}$ Mowris, History of the One Hundred and Seventeenth Regiment N.Y. Volunteers, 68.
} 
unlettered masses of the South." ${ }^{64}$ The Slave Power kept the "unlettered masses of the South" in ignorance, thereby ensuring their own continued dominion over them.

The Slave Power's influence extended even the southern landscape. Regimental historians commented favorably on the environment in the South. To them, it appeared as an exotic and interesting locale, filled with fascinating sights and strange creatures. John Kinnear of the 86th Illinois Infantry Regiment described with rapture the landscape in northern Georgia: "This vicinity of the South is noted for its grand natural scenery, nowhere to be surpassed. We read of the romantic scenery of the Oriental world--of the versatility of Italia's summer winds--of the magic charms of her hills, her rills, and dales; but the realities here presented as more enchanting than the probabilities of a might be in other parts of the world." 65 Others marveled at the fauna, noting "alligators of immense dimensions and familiar habits; moccasin snakes of domestic tendencies, crawling into tents for shelter and frequently monopolizing the blankets of the men." ${ }^{66}$ Historians perceived the South as a lush, verdant, if somewhat unfamiliar landscape.

Regimental historians explained to their readers the baleful effect that the Slave Power had upon the southern land. Louis Boudrye avowed that he was "peculiarly impressed with the vastness of the forests" in Virginia. It differed "from the impressions we had formed of Virginia when reading of its early settlement, and its agricultural advantages." He found it perplexing that so much productive land lay unused beneath the trees. He argued that "the system of labor" created "this backwardness in agricultural

\footnotetext{
${ }^{64}$ Robert C. Eden, The Sword and the Gun: A History of the 37th Wis. Volunteer Infantry, from its First Organization to its Final Muster Out (Madison: Atwood \& Rublee, 1865), 40.

${ }^{65}$ Kinnear, History of the Eighty-Sixth Regiment Illinois Volunteer Infantry, 37-38.

${ }^{66}$ Beecher, History of the 114th Regiment, N.Y.S.V., 130.
} 
pursuits." Boudrye meant "poor white trash" rather than enslaved African Americans, as he believed that if only people could "realize the true dignity of labor," then "the almost interminable forests disappear, and in their places the industrious yeoman will behold his rich fields of waving grain." After the yeoman would come the "factory and the mill, whose fabrics bring wealth and prosperity to the nation." ${ }^{67}$ Warren Cudworth, likewise, found the environs of Virginia's Middle Peninsula "remarkable alike for its beauty and fertility, and in [the] proper hands might be made a paradise." But he also thought "a new race was evidently needed to save the land from sinking into a wilderness." ${ }^{68}$ The historians of the 11th Ohio Infantry Regiment believed the Kanawha Valley of West Virginia "for productiveness can not be excelled." It abounded "in all the most useful minerals--salt, coal, and oil to be had almost for the asking." Akin to Boudrye and Cudworth, they contemplated that "nothing but a moderate degree of 'Yankee' enterprise is needed to make this most remarkable valley more valuable than the mines of California or Australia." ${ }^{69}$ Critically, these comments all pointed toward southern whites as the problem in making the South agriculturally productive; the system of slavery had stripped them of respect for the "dignity of labor" and "enterprise."

Thus, regimental historians explained the coming of the Great Rebellion and what they saw in the South through the lens of the Slave Power conspiracy theory. Seeing southern leaders as scheming oligarchs who deceived and defrauded the white masses gave regimental historians a powerful framing tool for their works. Northern authors

\footnotetext{
${ }^{67}$ Boudrye, Historic Records of the Fifth New York Cavalry, 135.

${ }^{68}$ Cudworth, History of the First Regiment (Massachusetts Infantry), 184.

${ }^{69}$ Horton and Teverbaugh, History of the Eleventh Regiment (Ohio Volunteer Infantry), 27.
} 
could conceive of themselves as the protectors of republicanism in the world while also avoiding difficult questions regarding the role of African Americans in the war. Regimental historians narrated the war from their perspective and the basis of that narrative lay upon the thought that their sacrifices secured a rejuvenation of freedom for white America that a slaveholding aristocracy had nearly strangled in its cradle.

While regimental historians seldom referred to African Americans when discussing the causes of the Great Rebellion, they encountered them in the South. Enslaved African Americans and recently freed blacks appeared in regimental histories as part of the landscape the soldiers encountered. Soldiers often expressed sympathy toward blacks, but they never fully integrated African Americans into their narratives. As discussed above, the narratives in regimental histories focused very tightly on the experience of white northern soldiers and their personal roles in the conflict. That African Americans could appear in the regimental histories, yet not in a central role--either in the coming of the war or during it--suggests that regimental historians never embraced an emancipationist narrative of the Civil War. The closest authors came to embracing African Americans in their narrative came with the United States Colored Troops (USCT). Soldiers could praise the USCT unabashedly, as the USCT and the white troops inhabited similar ground: both served as soldiers. Yet even then, regimental historians' praise of the USCT remained confined to wartime.

While regimental histories generally agreed that a slaveholding oligarchy had engineered the war, much less consistency among the narratives existed regarding the enslaved African Americans themselves. On one extreme lay Chaplain Warren Cudworth's History of the First Regiment Massachusetts Infantry. As might be expected 
of a chaplain from Boston, Cudworth took a remarkably tolerant and understanding view of African American culture. He noted that the enslaved "greeted our coming among them with almost unconcealed delight, and were of the greatest possible service." $\mathrm{He}$ enthusiastically welcomed the "Proclamation of Emancipation" because he thought its "influence in deciding the doom of the Rebellion...potent and irresistible. It was better than many victories gained by gunpowder and battalions; being a declaration for justice and righteousness. ${ }^{70}$ Another chaplain, Moses Gage, admonished: "Let none say that the bondmen do not love their liberty, when such cheerfulness is manifested in the midst of trials attendant upon the pursuit of that object." ${ }^{71}$ The chaplain of the 6th Massachusetts Infantry Regiment, John Hanson, wrote of "the long files of dusky pilgrims [who] came in...dragging the household penates," much as Aeneas rescued the household gods from Troy in order to found Rome. Though these escaped enslaved presented a ragged appearance, Hanson "found them intelligent as, and every way the equals, and in ability to take care of themselves the superiors of, the white people left in our neighborhood." Hanson also "was very much interested in the fact that [black] worshippers would pray with great fervor for our soldiers. One eloquent petition referred to them as dashing through the 'roar of the cannon, the smoke of battle, and the flash of the rifle' and supplicated the Divine protection for them, in terms that would have done honor to any prayer." In other instance, Hanson preached alongside a black minister. He recalled: "with an audience of white and black, of ministers and laity, and of many denominations, we, a Universalist and Methodist preacher, administered the communion. It seemed a

\footnotetext{
${ }^{70}$ Cudworth, History of the First Regiment (Massachusetts Infantry), 90, 336.

${ }^{71}$ Gage, From Vicksburg to Raleigh, 293.
} 
foregleam of the millennium, as we all worshipped together; for, though speaking many sectarian dialects, we were united in one spirit."72

Though chaplains most often exhibited this tolerance, other regimental historians expressed sympathy for the plight of the slaves. Lyman Pierce of the 2nd Iowa Cavalry exclaimed "What a comment upon the institution of slavery, that it crushes even poor whites, with whom it comes in contact, until every spark of manhood becomes extinct. Who, after such a sight, will brand the black race unfit for freedom, and assign as a reason for the course the fact that they lack the snap usually seen in the free Anglo-Saxon of the North? Can we expect the negro to withstand the direct influence of an institution, the indirect contact of which has so degraded our race?"73

Major George Wood, of the 7th Ohio Infantry Regiment from the abolitionist hotbed of the Western Reserve, wrote the most understanding account of slavery. Wood felt "confident that the slaves of the South, were just as well informed with regard to their relation to their masters, as we were." Wood continued, "it is well enough to talk of the deep devotion of slaves to their masters; but the later have found ere this, I trust, that this devotion of which they have relied, has not prevented them from cutting their throats, when it was in the line of their duty, and by means of which they could gain their freedom." Wood also wrote of how enslaved African Americans "obtain[ed] scraps of newspapers and parts of books, and thus gain[ed] a great deal of information entirely

\footnotetext{
${ }^{72}$ John W. Hanson, Historical Sketch of the Old Sixth Regiment of Massachusetts Volunteers During Its Three Campaigns, in 1861, 1862, 1863, and 1864: Containing the History of the Several Companies Previous to 1861, and the Names and Military Record of Each Man Connected with the Regiment During the War (Boston: Lee and Shepard, 1866), 161, 169-70.

${ }^{73}$ Pierce, History of the Second Iowa Cavalry, 120.
} 
unobserved." He greeted emancipation with joy: "What a glorious thought! thousands of oppressed fighting for the redemption from slavery of a race which has ever worn the chain. When it is remembered that by this strife questions are to be settled which have ever disturbed the harmony of this country, and not only that, but questions which, when settled, will release millions of our fellow-men and women from the power of the oppressor, ought we not to be thankful that we are permitted to make great sacrifices in so good a cause?"74

On the other hand, some regimental historians expressed less empathy for the enslaved and typically viewed blacks as amusing distractions. Robert Eden recalled "darkies 'Hurrahing and Hallelujahing' around us, accompanying their expressions of delight with a grotesque exhibition of antics and grimaces, and 'Bressing de Lord and the Yankees" [emphasis in original]. ${ }^{75}$ Stephen Fleharty found it strange that "the only class of people that seemed contented amid so much misery was the colored community." $\mathrm{He}$ disapproved of "one or two sleek, sable lasses who were accustomed to dance on the pavement with every manifestation of ecstatic delight," and lamented, "Poor creatures, they scarcely realized their own wretchedness. ${ }^{76}$ Harris Beecher thought "it will take many years of education, and the enlightening effects of freedom, to bring [blacks] up to the proper standard of intelligence." He recalled that "one of the chief sources of amusement, among the soldiers, was in visiting negro dances and prayer meetings. These last are the most singular and impressive sights imaginable, consisting of weird songs,

\footnotetext{
${ }^{74}$ Wood, The Seventh Regiment, 77-78, 81-82.

${ }^{75}$ Eden, The Sword and the Gun, 51.

${ }^{76}$ Fleharty, Our Regiment, a History of the 102d Illinois Infantry Volunteers, 29, 125.
} 
incoherent shouts, mingled with violent contortion, wails and moans, quaint prayers and response." While initially amusing, Beecher complained that once the novelty wore off, "the night was made hideous by their dances and prayers meetings" which "disturb[ed] the sleep of the men." ${ }^{77}$ W.W.H. Davis of the 104the Pennsylvania Infantry also viewed African-American religious ceremonies unfavorably; they were "evidently a heathen ceremony handed down from their African ancestors, somewhat modified by their Christian training." Samuel Hurst found that "many were ignorant and degraded as brutes almost; but some were intelligent." 78

Other historians voiced their doubts as to the future of blacks in the country. Robert Eden of the 37th Wisconsin Infantry Regiment described the freed slaves thusly: "Africa, of all shades, from the genuine sable 'mungo,' with skin like polished ebony, and showing from between his extended gums a formidable array of ivory, to the graceful quadroon, hardly a shade darker, and very often a great deal handsomer than her late mistress, standing within a few feet of one another, all jubilant and triumphant, all rejoicing in their new found freedom." Contemplating the spectacle, Eden interjected: "Poor things, what their future may be, we know not." ${ }^{19}$ Samuel Merrill of the 1st Maine Cavalry Regiment fretted that "freedom you can give at once" but "the right to make contract, the obligations of which as equally binding on both parties... you cannot so readily confer." He feared "the most dreadful of all wars, a war of races." ${ }^{80}$

\footnotetext{
${ }^{77}$ Beecher, History of the 114th Regiment, N.Y.S.V., 80, 114-15, 264.

${ }^{78}$ Hurst, Journal-History of the Seventy-Third Ohio Volunteer Infantry, 155-56.

${ }^{79}$ Eden, The Sword and the Gun, 55.

${ }^{80}$ Merrill, The Campaigns of the First Maine and District of Columbia Cavalry, 373-74.
} 
Despite ambivalence concerning the general populace of African Americans in the South, regiments that had exposure to United States Colored Troops (USCT) praised them and commented favorably upon their appearance. Louis Boudrye of the 5th New York Cavalry Regiment remarked that "a brigade of colored troops occupy Old Church. They have fortified themselves with strong and beautifully constructed earthworks. They are fine appearing soldiers." ${ }^{81}$ Other soldiers took delight in the fact that formerly enslaved blacks controlled their former masters. Ellis Pellet crowed that "it was a source of infinite satisfaction to us, 'Northern mud-sills,' to see the 'chivalry,' the lords of broad acres, obliged to exhibit their 'passes' to the dark skinned sentinels--men, who in some cases, were formerly their 'chattels."' ${ }^{82}$ Edwin Houghton of the 17th Maine Infantry Regiment noted with glee "that official intelligence was received during the day, that the negro soldiers had taken possession of the long coveted city of Richmond. The joy that gladdened the hearts of all, at the intelligence of the fall of the proud and arrogant headquarters of treason, was not diminished by the fact, that the pride of the great southern metropolis had been humbled, and that it had been reserved for the colored soldiers to capture the rebel capital." ${ }^{83}$

\footnotetext{
${ }^{81}$ Boudrye, Historic Records of the Fifth New York Cavalry, 139.

${ }^{82}$ Elias P. Pellett, History of the 114th Regiment New York State Volunteers, Containing a Perfect Record of Its Services, Embracing All Its Marches, Campaigns, Battles, Sieges, and Sea-Voyages, With a Biographical Sketch of Each Officer, and a Complete Register of the Regiment, Wherein Appears the Name of Every Officer and Enlisted Man who has Ever Belonged to the Same, with Full Remarks Relating Thereto (Norwich: Telegraph \& Chronicle Power Press Print Co., 1866), 46.

${ }^{83}$ Houghton, The Campaigns of the Seventeenth Maine, 266.
} 
James Clark of the 115th New York Infantry Regiment watched as the USCT of the Ninth Corps charged rebel positions during the battle of the Crater on July 30, 1864: "Noble fellows! Grandly they cross the field; they are under a withering fire, but still rush on regardless of fallen comrades, and the storm of pitiless lead and relentless grape that pours upon them from three sides, and gain the works with a ringing cheer. Now they sweep everything before them." ${ }^{84}$ James Mowris, writing about the battle of Deep Bottom, recalled "on that occasion, those who were politically the most conservative, suddenly experienced, an accession of respect for the chattel on this discovery of its 'equal' value in a possible emergency." ${ }^{85}$ Thomas Murphey of 1 st Delaware Infantry Regiment concurred that "the prejudices against negro soldiers began to give way before Petersburg. Once soldiers unwilling to have them associated with them in the same army, but after the experience in battles on the north of the James, in charging upon fortified positions, they were very willing...to have colored troops come up before the entrenchments around Petersburg." 86

The charge of the "Negro brigade" during the battle of Nashville elicited similar comments from Louis Simmons of the 84th Indiana Infantry: "But danger and death did not cause them to waver a moment, nor repress the terrible fury of their victorious charge. They stormed and took a line, that one of the best Brigades in our whole army had failed

\footnotetext{
${ }^{84}$ Clark, The Iron Hearted Regiment, 148.

${ }^{85}$ Mowris, History of the One Hundred and Seventeenth Regiment N.Y. Volunteers, 113.

${ }^{86}$ Thomas G. Murphey, Four Years in the War: The History of the First Regiment of Delaware Veteran Volunteers (Infantry), Containing an Account of Marches, Battles, Incidents, Promotions, and the Names of All the Officers and Men Who Have Been Connected with the Regiment from Its Organization in 1861 to the Close of the War (Philadelphia: James S. Claxton, 1866) ,174.
} 
to carry. Yet these were the men who were recently chattels; who we were so reluctant to see mustered as soldiers, and of whom it has been so often said 'they won't fight."' 87 George Powers of the 38th Massachusetts Infantry Regiment resented press coverage of the USCT engaged at Port Hudson, but while grumbling about the "exaggerated accounts of their bravery" also understood that "it had been the fashion for so long to decry the courage of the colored man, and deny him the attributes of manhood, that, when he proved himself more than a beast of burden, public opinion went to the opposite extreme." 88

Regimental historians included blacks in their narratives because enslaved and refugee African Americans had been a part of their experiences in the South. Just as they documented the wretched hovels of poor whites, fruitful land uncultivated, and shoddy towns, they told of the enslaved and the contrabands. Yet they refused to place the enslaved themselves at the center of their narratives. Rather than seeing emancipation as a humanitarian goal in the statements of purpose in their histories, they relegated it to another strange sight in the South and tertiary outcome of the war. Authors preferred to explain the war as a result of the white elite who constituted the Slave Power; if the war had been about freeing the slaves, it was not evident in immediate retrospect.

A consensus existed among Union soldiers at the end of the war. The conflict had been fought over slavery, because slavery had made possible the development of an aristocracy in the United States. Foolishly, the slaveholding oligarchy attempted to destroy the Union through the act of secession. With the aristocracy deposed and slavery

\footnotetext{
${ }^{87}$ L. A. Simmons, History of the 84th Reg't Ill. Vols (Macomb: Hampton Brothers, 1866), 227.

${ }^{88}$ George W. Powers, The Story of the Thirty-Eighth Regiment of Massachusetts Volunteers, 90-91.
} 
removed, the United States could continue on its path toward liberty and democracy. Resentment toward the South focused on the leaders of the Great Rebellion, not the common Confederate soldier or the civilians at home. Regimental historians viewed those two groups with sympathy, seeing them as victims of the elites. Antipathy toward slavery on the part of northerners stemmed more from fears that slavery corrupted white Americans, both North and South, rather than an desire to ameliorate the condition of enslaved African Americans. Union soldiers believed that because they had prevailed and definitively ended slavery, the war had been won.

The implications of these view extended far beyond the individual soldiers who penned regimental histories. As concrete evidence of a soldier's service, the regimental history provided a memento to his friends and family. The narratives of the war contained in them, once shared with the home community, helped knit together the soldier and the civilian and establish a narrative of shared sacrifice. The veteran spoke with authority and codified the meanings of the Civil War.

Regimental histories call into question the findings of David Blight and others who have argued that over the course of Reconstruction and the second half of the nineteenth century white Northerners abandoned African Americans in the South. According to Blight, narratives of the Civil War as an emancipationist moment and struggle fell out of favor; anodyne tales of shared sacrifice and generals arguing over the minutiae of individual battles became the story of the Civil War. The authors of regimental histories, however, never saw the war as being about emancipation. They saw the war as the story of themselves, the soldiers who sprang to the defense of republicanism in the world. Freedom for the enslaved African Americans arose as a 
tertiary outcome of the conflict. While authors included African Americans in their narratives, they appeared only as supporting players. Regimental histories, when examined closely, suggest that the reconciliationist narrative emerged in 1865 and 1866. Union soldiers had done their duty of humbling the aristocracy and robbing it of its power. The upas tree enshrined in the Constitution had been uprooted. Some soldiers would continue to draw upon these ideas far into the postwar period, suggesting that they deeply and sincerely believed in them. 


\section{Chapter 5 \\ "Bugles of Liberty:" Military Order of the Loyal Legion of the United States Veterans Remember Their Struggle Against the Slave Power \\ $* * * * * * * * * * * * * * * * * * * *$}

On July 11, 1883, Dr. Andrew Kemper of Ohio arose to deliver a speech to the Ohio Commandery of the Military Order of the Loyal Legion of the United States (MOLLUS). The comrades, as they called each other, typically spoke upon their personal experiences during the Civil War, delivered a panegyric to a favored commander, or recounted the events of a pivotal battle. Kemper, who had left his profitable medical practice to serve as a staff officer for generals Henry Wager Halleck and Horatio G. Wright, had something much more different in mind for his talk.

Kemper began his speech by invoking the English poet Alexander Pope's imitations of the Roman lyricist Horace, with the following verses. Without a poet to sing their praises, the dead of the war had suffered for naught. Without a poet to keep their deeds alive, "in vain they bled! They had no poet, and are dead." ${ }^{1}$ Wishing to fill the void, Kemper delivered his own extensive, allegorical ode about the Civil War, taking as his viewpoint the perspective of a soldier surveying the carnage of a battle on the night after.

\footnotetext{
${ }^{1}$ Citations for these sources present the original publication information (if a reprint) followed in brackets by the standardized volume title in the Broadfoot Publishing reprint edition. Andrew C. Kemper, "The Night After the Battle," in Sketches of War History, 1861-1865: Papers Read Before the Ohio Commandery of the Military Order of the Loyal Legion of the United States 1883-1886 vol. I [Military Order of the Loyal Legion of the United States: Ohio vol. I] (reprint; Wilmington, NC: Broadfoot Publishing Company, 1991 [1888]), 37.
} 
After describing the heroic deeds of the Union soldiers, Kemper drew back to describe in verse a series of discussions with the wounded who still remained on the field. In high romantic style, Kemper had a dying soldier declare with his last exhalation "Then I resign,/My country, God obey,/ To them my holy cause consign,/ My life-blood ebbs away./ My life, its hopes, and duty, all,/ None can bring richer store,/ I'm proud I can obey the call,/ I wish I could give more." Here, Kemper introduced an idealized Union soldier, who had selflessly given his all to serve his country and God. Continuing his poem, and his journey through the store of popular images of the Civil War, Kemper's narrator came across a pair of corpses; "Embraced in death twin brothers fondly lay,/ One clothed in blue, the other dressed in gray." Here emerged a powerful vision of the reconciliation between the North and the South, after all, that had been the goal of the Union war effort. Moving from that pathetic scene, he continued to tell his audience of the vast ranks of Union armies, the men from the cities, the farmers who had joined the ranks, and put in all their mouths belabored verses invoking God's grace and the noble deaths they received as they sanctified the Union. Making sure that he included all the Union troops, Kemper even imagined an African American soldier lying dead on the field. His narrator stopped to muse, "Before some cabins where he bravely fought,/ And earned worthy the mention he sought,/ Among the honored names his country bears,/ Upon the breast-plate she proudly wears,/ A negro fell, his front upon his foes,/ On whom his valiant hand had rained its blows." ${ }^{2}$ After he had briefly mentioned the former enslaved man who had fought for the Union cause and his freedom, he turned his attention to the foe.

\footnotetext{
${ }^{2}$ Ibid., 42, 43, 46.
} 
Kemper described "A captain of the South expiring lay/ Beneath a stately pine tree's mournful sway." Such a scene gave him the opportunity to put in the Confederate's mouth an explanation for secession and the Civil War. The dying Confederate managed to recite this "sad lament" before shuffling off this mortal coil:

My judgment clears in dissolution's gloom And marks my sad mistake a traitor's doom, With cunning sophistry, inwrought with lies, Concealing fearful wrongs in truth's disguise, The selfish schemers led away my hear, Curses forever on their wicked art, The whole earth round no milder rule obtained, No stronger arm her subject's rights maintained, I was not burdened with unjust restraint, I had no cause in reason for complaint, My country's heritage of fame was mine, Round hers my future might in grandeur twine, What cruel fate that I should die the tool, Of ingrate rebels against such a rule;

He who would organize a stable state Must find in cause a justice adequate, Nor lay the corner-stone on human slavery, For fear God's wrath should crush his flagrant knavery. ${ }^{3}$

With this extended soliloquy, Kemper gave a succinct account of the causes of the Great Rebellion. The imaginary rebel, dying, could see clearly what had eluded him in life. He saw that "sophistry" and "cunning lies" spun by "selfish schemers" had pried him away from his "country's fame of heritage." This section stood in stark contrast to the description of the Union soldiers, who expired while affirming their commitment to justice, right, and God. With the last couplet, Kemper invoked Confederate Vice President Alexander Stephens's claim that slavery served as the "corner-stone" of the Confederacy. Here, Kemper judged it a foundation of sand, the very height of "flagrant knavery." In his poem, Kemper drew upon the idea of the Slave Power conspiracy to

\footnotetext{
${ }^{3}$ Ibid., 47-8.
} 
explain the Civil War. The Confederate soldier had been deluded into fighting against right. And this Confederate inhabited the same literary space as the Union and Confederate entwined together in death; the Slave Power thesis both facilitated reconciliation and the emergence of the Lost Cause.

While extraordinary in his commitment to verse, Kemper was quite ordinary among the veterans of the MOLLUS in that he used the Slave Power conspiracy thesis to explain the Civil War. For Kemper, and other veterans of the Loyal Legion, it remained important for them to share with their listeners the ideology that had sustained them during the war. Even far after the conclusion of the war, veterans relied upon the Slave Power thesis to explain the coming of the Civil War. For them, the war had provided them the chance to demonstrate their patriotism as soldiers; when the guns fell silent, they had accomplished their task of defeating a domestic aristocracy that sought to dismantle republicanism. During the wartime years, the Slave Power thesis emerged from soldiers' writings and diaries as a largely implicit theme, but when soldiers reflected at greater length they developed the theme more extensively. Secession had proved the Slave Power conspiracy existed, the war confirmed it, and during the postwar years, former soldiers used the thesis to aggrandize their own roles within the conflict. During the war, the Slave Power conspiracy theiss had allowed some soldiers to separate emancipation from antipathy towards African Americans; after the war, the Slave Power thesis enabled some soldiers to define the impact of the Civil War in terms divorced from the political struggles of Reconstruction and the Gilded Age. So, while some MOLLUS veterans acknowledged the role of African Americans within the conflict, they did not see emancipation as the central legacy of the Civil War. 
Scholars concerned with the memory of the American Civil War have, on the whole, argued that several decades after the end of the war, white Americans set aside talk of slavery's role in the Civil War. Instead of trying to create an egalitarian America, northerners embraced reconciliation with white Southerners at the expense of African Americans. In his influential synthesis, historian David W. Blight argued that white supremacy and a desire for reunification in the wake of the war resulted in the obliteration of the role slavery and the enslaved themselves played during the Civil War. By Blight's account, "romance triumphed over reality, sentimental remembrance won over ideological memory." Northerners, who had accepted emancipation as the most critical war aim, became exhausted during Reconstruction. Unable to sustain political will to push for African-American equality, they instead settled for reunion with white Southerners, which came at the cost of endorsing segregation and Jim Crow regimes across the South. Instead of justice, northerners embraced the so-called Lost Cause narrative crafted by white Southerners, which focused on the brave struggle of Americans who had been overwhelmed only by superior numbers. The Lost Cause narrative minimized the role that slavery had played in the Civil War while stressing that the Confederate cause had been moral. Blight concluded that whites crafted a "collective victory narrative," in which "the Civil War, followed by an interlude of bitterness and wrongheaded policy during Reconstruction, became the heroic crisis survived" and provided "a source of pride that Americans solve their problems and redeem themselves in unity." Thus, by the start of the twentieth century, the Civil War had become a painful, yet necessary step on the way to a reinvigorated white republic. This self-satisfied 
narrative rested almost entirely upon forgetting that slavery had anything to do with the war. ${ }^{4}$

Historian Earl J. Hess, in a perceptive analysis, identified three pillars of wartime Union ideology: liberty, virtue, and progress. A commitment to spreading republican liberty because the system was the most virtuous led to progress. He found that this deeply "moral purpose underlay the Northern war effort." Northerners embarked upon the Civil War to secure these goals, and as the war progressed "they also came to realize that slavery had to die along with the Confederacy." ${ }^{5}$ While Blight saw emancipation as the defining event of the Civil War, Hess saw it as an incidental outcome of the war, albeit one of immense importance.

More recently, historian Robert Hunt has argued that Civil War soldiers maintained a consistent ideology regarding the war. They continued to espouse this ideology early into the twentieth century. Examining narratives of soldiers from the Army of the Cumberland, Hunt concluded that "the Cumberlanders' real war did make it into the collective memory." Their war included white Southern civilians as well as enslaved African Americans. In their postwar narratives, instead of effacing black participation, they acknowledged it. Yet they cast the freedom struggle in ways that buttressed their own ideals of fighting for liberty and justice, along the lines that Hess had laid out. According to Hunt, "as Cumberland veterans described it later, the war that ended in 1865 freed and made dominant the North's labor system...Liberated slaves were

\footnotetext{
${ }^{4}$ David W. Blight, Race and Reunion: The Civil War in American Memory (Cambridge: Harvard University Press, 2001), 4, 383.

${ }^{5}$ Earl J. Hess, Liberty, Virtue, and Progress: Northerners and Their War for the Union, 2nd Ed. (New York: Fordham University Press, 1997), 3.
} 
markers of power, dignity, and justice...or better, the act of liberating them was." Thus, while veterans recalled the "war as an emancipation event," they did so in ways that subordinated "the interior life and political condition of the slaves freed by the war" to their own narratives of national redemption and preservation." ${ }^{6}$ M. Keith Harris, writing about Northern veterans as a whole, has likewise found that "veterans of the Union cause articulated and fought to preserve memories of a war that pitted a Northern vision of Union against the institution of slavery." ${ }^{7}$ The papers delivered by MOLLUS veterans reinforce the trends that reinforces both Hunt and Harris, and helps demonstrate that many former Union soldiers recalled emancipation, but often defined the event in starkly different terms than the liberated African Americans themselves.

MOLLUS veterans participated in the effort to preserve their version of the Civil War. They fell back upon the ideal of liberty to explain their struggle; liberty for them meant the destruction of the homegrown aristocracy of the Slave Power. With the Slave Power swept out of the way, American republicanism could continue to grow and serve as a beacon on the world stage. Slavery had to go because it corrupted American republicanism; with that impediment gone, America could serve as the true beacon of progress for the world. The regional subcultures that had inflected their wartime interpretation of the Slave Power fell away; with retrospect the local variations mattered less while soldiers basked in the warm glow of the knowledge that their service had shattered the Slave Power, resulting in a more powerful and prosperous America. They

\footnotetext{
${ }^{6}$ Robert Hunt, The Good Men Who Won the War: Army of the Cumberland Veterans and Emancipation Memory (Tuscaloosa: University of Alabama Press, 2010), 19, 139.

${ }^{7}$ M. Keith Harris, "Slavery, Emancipation, and Veterans of the Union Cause: Commemorating Freedom in the Era of Reconciliation, 1885-1915," Civil War History Vol. 53 No. 3 (September 2007), 269.
} 
also thought that overthrowing the last vestiges of aristocracy in America stood as an accomplishment on a global-historical level. In a period of increasing change, veterans relied upon the larger concept of the struggle against the Slave Power to justify and aggrandize their role in the American Civil War. ${ }^{8}$

As distinct regional subcultures eroded under the pressure of an increasingly homogenized national culture, veterans replaced them with a near-mystical tie to the past. The MOLLUS members propounded an explicit conception of itself as the inheritor of the American Revolution. They saw themselves as scions of freedom who kept alive the true meaning of the Civil War. Thus, their postwar testimony trumpeted the beneficial role of liberty, their role in securing it, and the American Civil War's status as another example in a long list of historical events demonstrating that their cause prevailed because it had been just. As Anne C. Rose has noted, Americans before the Civil War had often turned toward religion as consolation. However, as secularism spread during the nineteenth century, Victorians felt "keen disappointment at the failure of the founders' republicanism" they found near-mystical attachment to it that substituted a "glory and shared idealism" drawn from it to replace diminishing theological faith. According to Rose, the war "convinced" many "that human effort even without clear supernatural references still had value." ${ }^{9}$ The veterans of MOLLUS portrayed themselves as soldiers in a long line of those who had sprung to defend human liberty, reaching back to Biblical times and antiquity, but more recently found in the generation that had led the American

\footnotetext{
${ }^{8}$ For a discussion of the broad shifts underway in late nineteenth century America, see: Robert H. Wiebe, The Search for Order, 1877-1920 (New York: Macmillan, 1967).

${ }^{9}$ Anne C. Rose, Victorian America and the Civil War (Cambridge: Cambridge University Press, 1992$), 5$.
} 
Revolution. The Slave Power thesis allowed them to portray their struggle as the success of the founders' republicanism, which had failed as a result of the machinations of the white Southern slaveholding cabal, and thereby a success worthy of global notice.

The MOLLUS defined itself as an organization steeped in the heritage of the American Revolution. The members of the order delivered papers that situated the Civil War within a global-historical framework that placed America as the protector of liberty in the world. For them, the Civil War had fulfilled the promise of the Revolution by excoriating the last vestiges of feudalism and chivalry in the United States. In the wake of the war, they saw the need for a society dedicated to securing the fruits of victory. Their organization would remind Americans of the decades of failed compromise and the concerted effort of the Southern oligarchy to subvert the government for their own base goals.

Indeed, the founders of the MOLLUS consciously modeled their group upon one formed by officers of the Continental Army, the Society of the Cincinnati. The earlier veterans' institution owed its origins to what historian Minor Myers, Jr. has termed "a mutiny moderated into an organization." At the end of the American Revolution, disgruntled officers of the Continental Army thought that Congress has slighted their sacrifices over the course of the war, particularly as represented by parsimonious pensions and pay. Only a heartfelt address by General George Washington, known as the Newburgh Address, defused what might have been a potential armed coup. In the wake 
of Washington's address, General Henry Knox proposed a fraternal society of officers to provide monetary support and aid to needy members. ${ }^{10}$

Although it began as an aid organization, other Americans detected in the Society of the Cincinnati a dangerous group with nefarious political goals. In their view, they saw the society as an elitist and aristocratic cabal that, built upon the upper-class officer corps of the Continental Army, sought to create a domestic aristocracy. It appeared as if the foreign tyranny that had been swept away with the British would be replaced with a domestic one. Especially galling was the fact that Society admitted sons of the veterans into the group, thereby establishing hereditary succession that smacked of European aristocracy. Members of the Society, however, saw themselves not as a dangerous force, but as a standing vanguard that would ensure the success of the Revolution. Like their namesake, they believed themselves to be patriots who had returned home once the war had been won. But, the Society of the Cincinnati began to become involved in politics. The turmoil and anarchy during the years of the Articles of Confederation convinced members of the Society that America needed their services still. As Myers has noted, members of the Society pushed for a stronger central government and a Constitution as necessary measures to preserve the gains of the Revolution. These activities, which took on a Federalist cast, only confirmed for Democratic Republicans that the Society aimed to subvert the rightful course of the American Revolution. ${ }^{11}$

\footnotetext{
${ }^{10}$ Minor Myers, Jr., Liberty Without Anarchy: A History of the Society of the Cincinnati (Charlottesville: University Press of Virginia, 1993), 1-19.

${ }^{11}$ Myers, Liberty Without Anarchy, 70-119.
} 
As the years passed and the direct political influence of the Society waned, fears regarding its role in America diminished. It came to be seen as less of a political organization and more of one devoted to venerating those who had served during the Revolution. By the time of the Civil War, the Society of the Cincinnati was seen by many as a repository of patriotism and republican virtue. It provided a living tie to the generation of the Revolution for Americans. Outright partisan political activities had been supplanted by patriotic pageantry, as the Society of the Cincinnati participated in celebrations of Washington's birthday and Independence Day festivities across the country. $^{12}$

This particular image of the Society provided Union veterans a model for the Military Order of the Loyal Legion of the United States. Appropriately enough for an organization that drew upon the Revolution, the MOLLUS began in Philadelphia, which had been the capital during the Revolution. On April 15, 1865, Colonel Thomas Ellwood Zell and several other officers, upon hearing of the assassination of President Abraham Lincoln, met to discuss the need for an organization devoted to preserving the Union victory. They feared that with the assassination of Lincoln, any gains of the Civil War would be washed away, much as the weak Articles of Confederation had almost strangled liberty in its cradle. Thus, a new organization separate from the army would be needed to protect the Union war effort into the postwar period. Zell and the others incorporated the first commandery of the MOLLUS at Independence Hall on May 31, 1865. With its

\footnotetext{
${ }^{12}$ Dana B. Shoaf, "'For Every Man Who Wore the Blue': The Military Order of the Loyal Legion of the United States and the Charges of Elitism after the Civil War," in Union Soldiers and the Northern Home Front: Wartime Experiences, Postwar Adjustments, edited by Paul A. Cimbala and Randall M. Miller (New York: Fordham University Press, 2002), 468-70
} 
founding, the MOLLUS became the second-oldest Civil War veterans' organization, preceded only by the Society of the Army of the Tennessee, which had been organized just the day before. ${ }^{13}$

While the Society of the Cincinnati possessed "a quality of grandeur," MOLLUS veterans represented much more humble origins. Members of the MOLLUS had to be

${ }^{13}$ For other accounts of the founding of the MOLLUS, see: E. A. Calkins, "History of the Loyal Legion," in War Papers: Being Papers Read Before the Commandery of the State of Wisconsin, Military Order of the Loyal Legion of the United States, vol. III [Military Order of the Loyal Legion of the United States: Wisconsin vol. III] (reprint; Wilmington, NC: Broadfoot Publishing, 1993 [1903]), 343-52; G. A. Hannaford, "The Loyal Legion," in War Sketches and Incidents as Related by the Companions of the Iowa Commandery of the Military Order of the Loyal Legion of the United States vol. I [Military Order of the Loyal Legion of the United States: Iowa vol. 1] (reprint; Wilmington, NC: Broadfoot Publishing, 1994 [1893]), 316-21; James H. Howe, "The Loyal Legion," in Glimpses of the Nation's Struggle: A Series of Papers Read Before the Minnesota Commandery of the Loyal Legion of the United States 2d Series, edited by Edward D. Neill [Military Order of the Loyal Legion of the United States: Minnesota vol. II] (reprint; Wilmington, NC: Broadfoot Publishing, 1992 [1890]), 280-88; Francis P. B. Sands, Military Order of the Loyal Legion of the United States: Commandery of the District of Columbia: War Papers 86: The Loyal Legion of the Civil War, in War Papers Being Read Before the Commandery of the District of Columbia, Military Order of the Loyal Legion of the United States vol. IV [Military Order of the Loyal Legion of the United States: District of Columbia vol. IV] (Wilmington, NC: Broadfoot Publishing, 1993), 262-77;

Henry H. Sibley, "Remarks," in MOLLUS: Minnesota vol. II, 223-26; E. B. Soper, "Our Order of the Loyal Legion," in MOLLUS: Iowa vol. I, 322-25; and The Commemoration of The Lincoln Centenary by the Ohio Commandery of the Military Order of the Loyal Legion of the United States at their Headquarters February 12, 1909 in Sketches of War History 1861-1865: A Compilation of Miscellaneous Papers Compiled For the Ohio Commander of the Loyal Legion February 1885-February 1909 [Military Order of the Loyal Legion of the United States: Ohio vol. VII] (Wilmington, NC: Broadfoot Publishing, 1993), 28788. 
officers, but they "consisted primarily of Anglo-Saxon white males engaged in white collar professions." One study found that in Massachusetts, nearly $70 \%$ of the Loyal Legion's membership engaged in white collar professions. Thus, while the MOLLUS remained more exclusive than other Union veterans' organizations, it was by no means a society devoted entirely to the richest men in the Union armies. ${ }^{14}$

Former general and president of the United States Rutherford B. Hayes described the founding of the MOLLUS in an address to members. He tied the MOLLUS to the Society of the Cincinnati, but also took care to reassure listeners that the more modern group harbored no political designs. He recounted the genesis of the MOLLUS in the uncertain days of April 1865: "It was as if General Washington and General Knox and Baron Steuben and their immortal associates had been called to take part in the deliberations of the men whose privilege it has been to stand by their country's cause." Hayes noted the political controversies that had swirled around the Society of the Cincinnati, but observed that it eventually came to be "regarded as an institution which worthily and honorably represented and preserved the heroic deeds of our country's golden age." He sought to allay fears that the MOLLUS would seek to involve itself in partisan politics, avowing that "The Loyal Legion is essentially the organic expression of our comradeship in a sacred war" and that "above all, our faith is in America. We believe in the study of America, its history, of its geography, and of the lives of its men and women." He also juxtaposed American ideals of freedom and liberty with slaveholding

\footnotetext{
${ }^{14}$ Myers, Liberty without Anarchy, 128; and Dana B. Shoaf, "'For Every Man Who Wore the Blue': The Military Order of the Loyal Legion of the United States and the Charges of Elitism after the Civil War," $468-70$.
} 
aristocracy and dangerous ideas that emanated from Europe. He proclaimed: "We prefer that their notions, their follies, their vices, and their perils should remain on the other side of the Atlantic." ${ }^{15}$ In his speech, Hayes sought to disarm fears that the MOLLUS would become active in partisan politics and reassure readers that all it sought was to preserve American liberty and republicanism against aristocracy, tyranny, socialism, and war. ${ }^{16}$

Other members of the MOLLUS emphasized how they saw their group as a continuation of the Society of the Cincinnati. According to Col. D. C. Kerr of the 16th Illinois Infantry Regiment, "The War of the Rebellion established and imposed upon us the duty of inculcating truths which our forefathers realized only partially." He cast the Loyal Legion as a successor to the early group; where "the glory of a nation created" marked the Cincinnati, the Loyal Legion bore the duty of keeping "a country preserved." He saw the MOLLUS, with its avowedly nonpartisan role, as specially suited for this educative mission. ${ }^{17}$ Capt. Thomas Mitchell, formerly of the 198th Pennsylvania Infantry

\footnotetext{
${ }^{15}$ Rutherford B. Hayes, "The Loyal Legion: An Address Delivered...October 7, 1891," in Personal Recollections of the War of the Rebellion: Addresses Delivered Before the New York Commandery of the Loyal Legion of the United States, 1883-1891, edited by James Grant Wilson and Titus Munson Coan [Military Order of the Loyal Legion of the United States: New York vol. 1] (reprint; Wilmington, NC: Broadfoot Publishing, 1992 [1891]), 374, 379.

${ }^{16}$ Dana B. Shoaf, in his examination of the Military Order of the Loyal Legion, has demonstrated that some Americans feared that the MOLLUS would behave in an elitist and aristocratic fashion, much as the Society of Cincinnati had. To combat these fears, the society "engaged in a variety of projects designed to highlight the patriotic motives of the organization and its commitment to service." Dana B. Shoaf, "'For Every Man Who Wore the Blue'," 474.

${ }^{17}$ D. C. Kerr, "The Loyal Legion" in Glimpses of the Nation's Struggle: Papers Read Before the Minnesota Commandery of the Military Order of the Loyal Legion of the United States, 1889-1892, 3d Series [Military
} 
Regiment likewise told his listeners that the Society of the Cincinnati took as its motto "a personal boast" while the MOLLUS took as its motto "a record merely of the end accomplished." ${ }^{18}$ He referred to the motto of the Cincinnati, "Omnia relinquit sevare republicam" (Everything is forsaken to protect the Republic), and that of the MOLLUS, "Lex regit, arma tuentur" (The law rules, arms uphold it). The MOLLUS, then, couched its very motto in a way that recalled the Revolution. Through their sacrifices, the Cincinnati had helped to establish the Republic at great personal cost. The MOLLUS, in contrast, only upheld the law of the land through the force of arms.

From these origins in 1865 , the MOLLUS would grow into a nationwide organization. The group structured its membership into three ranks: First Class, Second Class, and Third Class. For a veteran to join the First Class, he must have served as an officer in the Union armed forces during the Civil War. Much as with the Society of the Cincinnati, the Second Class enabled the oldest sons of First Class members to join. The Third Class served as a way to include civilians who had made exceptional contributions to the Union cause during the war. State chapters spread across the country, with commanderies created in New York (1866), Maine (1866), Massachusetts (1868), California (1871), Wisconsin (1874), Illinois (1879), the District of Columbia (1881),

Order of the Loyal Legion of the United States: Minnesota vol. 3] (reprint; Wilmington, NC: Broadfoot Publishing, 1992 [1893]), 133.

${ }^{18}$ Thomas Mitchell, The Kindred Organizations: The Society of the Cincinnati and the Military Order of the Loyal Legion of the United States: A Paper Prepared and Read Before California Commandery of the Loyal Legion of the United States, January 18, 1889 in Civil War Papers of the California Commandery of the Military Order of the Loyal Legion of the United States [Military Order of the Loyal Legion of the United States: California and Oregon] (Wilmington, NC: Broadfoot Publishing, 1995), 24. 
Michigan (1885), Minnesota (1885), Missouri (1885), Nebraska (1885), Oregon (1885), Iowa (1886), Kansas (1886), Colorado (1887), Vermont (1891), and Washington (1891). A national office was established in 1885 in order to help coordinate the state chapters. Membership ultimately reached into the thousands. While Rhode Island failed to establish a commandery, veterans there formed an organization based on the same ideals, the Rhode Island Soldiers and Sailors Society. With membership limited chiefly to officers, the MOLLUS always remained smaller than the Grand Army of the Republic, which had opened its ranks to all Union veterans. ${ }^{19}$

Beyond processing applications for memberships, the headquarters buildings of MOLLUS commanderies served as places for members to congregate and also served as repositories for information about the war. The Ohio chapter, for instance, occupied two floors of a building in downtown Cincinnati. Besides space to house administrative records, the structure contained a dining room, assembly room, and a library. As Robert Hunter, the recorder of the commandery, noted, the library "contains a large collection of books and pamphlets relating to the war of the Rebellion. It is especially rich in regimental histories, war-time photographs and maps of campaigns and battles."20

\footnotetext{
${ }^{19}$ Michael A. Cavanaugh, "Introduction to the Papers of the Pennsylvania Commandery Military Order of the Loyal Legion of the United States," in Military Essays and Recollections of the Pennsylvania Commandery Miitary Order of the Loyal Legion of the United States, February 22, 1866-May 6, 1903 [Military Order of the Loyal Legion of the United States: Pennsylvania vol. I], comp. Michael A. Cavanaugh (Wilmington, NC: Broadfoot Publishing, 1995), i-viii.

${ }^{20}$ Robert Hunter, "Historical Sketch," in Album: Portrait of Companions of the State of Ohio of the Military Order of the Loyal Legion of the United States [Military Order of the Loyal Legion of the United States: Ohio vol. VIII] (reprint; Wilmington, NC: Broadfoot Publishing, 1993 [1893]), 5-6.
} 
As the preoccupation with materials on the war demonstrated, the MOLLUS veterans devoted themselves to educating both themselves and America as a whole about the war. The various commanderies collected, published, and preserved wartime accounts from their members. Typically, they hosted communal dinners where veterans would present short papers on topics of their choice, although at time the MOLLUS commanderies would request that a speaker talk about a specific theme. After the paper had been read, the commandery would publish them; some chapters collected the pamphlets and reissued them in a single volume. Subjects ranged from the function of mules in the army, to the performance of General George H. Thomas at the Battle of Chickamauga, to the role of the United States Sanitary Commission and its charity fairs. The veterans saw these papers as part and parcel of the mission; their accounts preserved a record of their sacrifices. They also created an archive of virtue, ensuring that future generations would have ample sources that told the true story of the Civil War.

And while the MOLLUS veterans wrote often about battles and combat, they realized the limits of that discussion. They often spoke of the ambiguity of combat and the ephemeral nature of understanding how a battle unfolded and what it meant. They took care to emphasize for listeners that their papers gave only a piece of larger story. Capt. William E. Crane of the 4th Ohio Infantry Regiment reckoned that "a full and true history of the late war has never been written--never will be. But little links can be picked up--even as we pick up battered bullets on old battle-fields--and these may be welded together to make completer chains." ${ }^{21}$ Just as one small relic told only a small part of a story, so did veterans' accounts. Capt. James Carnahan of the 86th Indiana Infantry also

\footnotetext{
${ }^{21}$ William Crane, "Bugle Blasts," in MOLLUS: Ohio vol. I, 234.
} 
noted the role perspective played in accounts of the Civil War: "it is said that no two persons see the same rainbow, and it is especially true that each officer or soldier sees a different picture of the same battle."22

Lt. George G. Benedict of Vermont pointed out problems with battle accounts that claimed to be definitive. He observed "that much history, ancient and modern, hitherto accepted as a relation of facts, must be relegated to the sphere of myth." He explained that "at best all men do not see alike; not every man knows how to tell what he has seen; and truthful persons will give very different descriptions of incidents witnessed plainly by all and which they have no interest in misrepresenting." ${ }^{23}$ Benedict acknowledged and informed his audience of subjectivity, that perspective influenced perception. Thus, while they assiduously collected and distributed accounts of battles, the MOLLUS veterans saw themselves as offering different pieces of a whole that could be assembled later. Rather than simple antiquarian aggregation, the volumes of their papers represented a trove of testimony, often conflicting, that gave individual observations. ${ }^{24}$

\footnotetext{
${ }^{22}$ James R. Carnahan, "Personal Recollections of Chickamauga," in MOLLUS: Ohio vol. I, 403.

${ }^{23}$ George G. Benedict, War Paper No. 4, Vermont Commandery of the Loyal Legion, Read March 14, 1893: The Element of Romance in Military History in Vermont War Papers and Miscellaneous States Papers and Addresses for the Military Order of the Loyal Legion of the United States [Military Order of the Loyal Legion of the United States: Vermont \& Miscellaneous Papers] (Wilmington, NC: Broadfoot Publishing, 1994), 59, 62.

${ }^{24}$ The MOLLUS differed from the other large northern veterans' organization, the GAR, in this regard. The MOLLUS restrained its efforts to collecting and distributing these accounts rather than engaging in partisan politics. Stuart McConnell has noted that the accounts that the GAR published in its various periodicals also presented fragmentary sketches that veterans hoped would be knit into a future narrative. Stuart
} 
While MOLLUS accounts of battles often expressed doubt, or at least the awareness that the account of any one individual would not stand as definitive as far as troop maneuvers and battles were concerned, they evinced less doubt about the causes and meanings of the Civil War. In this key regard, their accounts differed from the reminiscences found in GAR publications. Historian Stuart McConnell has written that GAR accounts gave a "repeated lesson" of "national salvation." In these memorials and writings "prewar social and economic differences between the sections, issues of free labor and political power in the West, and especially the questions of blacks and slavery received scant mention...The war was mission accomplished; the nation, something maintained intact rather than something greatly changed." ${ }^{25}$ While the veterans of MOLLUS undoubtedly saw the Civil War as a "mission accomplished," they refused to remain silent on its causes of outcomes. They perceived the Civil War as a struggle of the same importance of the American Revolution and an affirmation of the earlier war, a connection drawn tighter through their references to the Society of the Cincinnati. They saw their struggle against the Confederacy in terms of expanding liberty brought up short by domestic tyranny. They pointed out, repeatedly, how a southern slaveholding oligarchy had perverted the course of the nation and their self-interested schemes had brought on the war. Frequently, and at great length, the MOLLUS veterans blamed the war on the Slave Power.

McConnell, Glorious Contentment: The Grand Army of the Republic, 1865-1900 (Chapel Hill: University of North Carolina Press, 1992), 173.

${ }^{25}$ McConnell, Glorious Contentment, 181. 
Veterans of the MOLLUS often ascribed the causes of the Civil War to white southern avarice, which had brought on secession. Thomas Barr of the Judge Advocate General described the Civil War as an economic struggle. In his account, the "love for the principles upon which the Republic was predicated had seemingly been lost sight of in the struggle for commercial success." Rather than seeing a mutual divergence between regional economies in the slaveholding South and the burgeoning industrialization along the Great Lakes littoral, Barr thought that the heart of the struggle lay in "the arrogant demands of the slaveholding oligarchy." He expanded upon this idea, informing his audience that "It was not alone a contest for the North that was waged by the Union soldiers. It was for the South as well; and in its outcome the people of all lands had a deep interest." ${ }^{26}$ Here, Barr expressed the common idea that even the people of the South had been misled by their leaders. The manipulations of the oligarchy for more lucre explained secession, rather than any democratic or grassroots support among the wider white populace.

Veterans often pinned responsibility for secession upon the southern oligarchy alone in this manner. Capt. Jacob W. Wilkin, formerly of the 130th Illinois Infantry Regiment, thought that "the great majority of the southern people had been led, through the false teachings of their political leaders" to believe "secession would be submitted to"

\footnotetext{
${ }^{26}$ Thomas F. Barr, "Costs and Compensations of the War," in Military Essays and Recollections: Papers Read Before the Commandery of the State of Illinois, Military Order of the Loyal Legion of the United States vol. I [Military Order of the Loyal Legion of the United States: Illinois vol. I] (reprint; Wilmington, NC: Broadfoot Publishing, 1992 [1891]), 519-20, 524.
} 
by the North. ${ }^{27}$ Maj. E. J. Harkness of the 6th United States Colored Troops likewise pointed to Southern leaders as the originators of the Civil War. He declared that "it was initiated by the South and was the result of a preconceived plan long contemplated by Southern leaders, but carefully matured during the administration of James Buchanan.”28 John Dennis, a former captain in the 7th Connecticut Infantry Regiment, also condemned the secessionist cabal for having started the war. He asserted that the Civil War sprang from the festering designs of a few "leaders who well knew that they must have some sort of pretext to go before their people with." The emissaries of these men "went ranting and tearing through the southern states, firing the people." 29

Other veterans enlarged upon these themes, seeing the deceptions of the despots as the true heart of the Confederate struggle. They refused to believe that any sincere support for the Confederacy had motivated the rank and file. Lyman G. Wilcox, a major in the 3rd Michigan Cavalry Regiment, told of an address he gave to citizens in occupied Tennessee in 1863 . He proclaimed that "The people of the South were throttled by a military force...so far as the Confederate army was concerned, it was but an enlarged and

${ }^{27}$ Jacob W. Wilkin, "Vicksburg," in Military Essays and Recollections: Papers Read Before the Commandery of the State of Illinois, Military Order of the Loyal Legion of the United States vol. IV [Military Order of the Loyal Legion of the United States: Illinois vol. IV] (reprint; Wilmington, NC: Broadfoot Publishing, 1992 [1907]), 215.

${ }^{28}$ E. J. Harkness, "Reflections Concerning the War," in MOLLUS: Illinois vol. IV, 529.

${ }^{29}$ John B. Dennis, "March of the Sixth Massachusetts Through Baltimore," in Civil War Sketches and Incidents: Papers Read by Companions of the Commandery of the State of Nebraska, Military Order of the Loyal Legion of the United States [Military Order of the Loyal Legion of the United States: Nebraska] (reprint; Wilmington, NC: Broadfoot Publishing, 1992 [1902]), 122. 
strengthened normal condition of the South, officered and directed by an imperious oligarchy." Using his observations from travels in the South as evidence, he posed a rhetorical question to his southern audience: "What have you in the slave States? Worn out plantations, dilapidated cities, 4,000,000 men in chains, driven by an idle and purseproud aristocracy, without schools, and a large portion of the people almost without homes." He claimed that secession "was done that slavery might be made the foundation of a new empire, and a class become the rulers and titled aristocracy of the land. ${ }^{30}$ Capt. James P. Moore of the 8th Illinois Infantry Regiment and 145th Illinois Infantry Regiment alleged something similar, noting that "visions of a Southern Empire, dominated by a slave-holding oligarchy, haunted the brain of John C. Calhoun and other ambitious Southern politicians" before bearing fruit with secession. ${ }^{31}$ Sometimes soldiers pointed to the secession conventions themselves as evidence of manipulation; Col. James Savage of the 12th New York Cavalry Regiment claimed that "North Carolina was literally forced out of the Union...by a convention possessing neither the legal authority nor moral right to pass such an ordinance. ${ }^{32}$

\footnotetext{
${ }^{30}$ Lyman G. Wilcox, "The South in War Times," in War Papers: Being Papers Read Before the Commandery of the State of Michigan, Military Order of the Loyal Legion of the United States, from December 7, 1893 to May 5, 1898 [Military Order of the Loyal Legion of the United States: Michigan vol. II] (reprint; Wilmington, NC: Broadfoot Publishing, 1993 [1898]), 12, 23, 32.

${ }^{31}$ James P. Moore, "War's First Rude Alarm in 1861," in Glimpses of the Nation's Struggle: Papers Read Before the Minnesota Commandery of the Military Order of the Loyal Legion of the United States, 18921897, 4th Ser. [Military Order of the Loyal Legion of the United States: Minnesota vol. IV] (reprint; Wilmington, NC: Broadfoot Publishing, 1992 [1898]), 8.

${ }^{32}$ James W. Savage, "The Loyal Element of North Carolina During the War," in MOLLUS: Nebraska, 2.
} 
Joshua Lawrence Chamberlain, famed for the exploits of the 20th Maine Infantry Regiment on Little Round Top at the Battle of Gettysburg, told listeners that "it was the madness of a few that precipitated the crime" of secession, and "there was, unfortunately, in the cherished tone and temper of the Southern mind something which made the way too easy for the plotters of this iniquity." He continued that white Southerners considered themselves "the natural masters of this country" and "it is not in accordance with the spirit of our institution to base claims to consideration on the merits of ancestors." As with other MOLLUS speakers, Chamberlain pointed out that "the gentleman of the faction succeeded in establishing their own belief and elsewhere a certain vague reputation of possessing to a miraculous degree of chivalry on the country and of modern times." He lamented: "But it was not, alas! the chivalry which has lent a dignity to romance and a grace to history." ${ }^{33}$ In his account, Chamberlain identified key threats to republicanism in the southern elite, most importantly hereditary aristocracy that led them to feel that they were superior to other Americans and the influence of self-interested faction in politics.

Franklin M. Drew, a former major of the 15th Maine Infantry Regiment, offered a sweeping overview of the causes of the Civil War. He identified the primary cause of the war as "the different civilizations which grew out of the diverse temperament, condition, and environment of the peoples of the North and South." He asserted that the Puritan spirit exemplified the North, while the Cavalier represented the South. In doing so, however, he also advanced an argument that harkened back to the Slave Power thesis. He thought the Cavalier "aristocratic in thought and feeling," which led to a love for power

\footnotetext{
${ }^{33}$ Joshua Lawrence Chamberlain, "America's First President," in MOLLUS: Pennsylvania vol. I, 14-15.
} 
that became concentrated in the hands of the white elite of the South. Consequently, in their ever increasing lust for more wealth and power, the political leaders of the South set about "uniting selfish interests and state pride," which resulted in beguiling the population of their states to support them. With the elite manipulating the masses, the common whites of the South bore no stain on their escutcheon for supporting the Confederacy. Drew thought that Confederate soldiers had "fought nobly, and performed deeds of valor in their efforts to establish the confederacy," but that they had ultimately been "wickedly misguided by their leaders." 34

Focusing on the machinations of Southern leaders allowed veterans to become reconciled with the Confederate rank and file. Capt. Charles H. Sweeney, a former staff officer, delivered an address that exemplified how the Slave Power thesis could foster reconciliation. Entitling his comments "Our Friend--The Enemy," he maintained that northerners had failed to understand the common Confederate soldier during the war. They had missed that southern "leaders educated the people, to believe, that the war upon the part of the North was intended, and declared solely, for the purpose of freeing the negro." ${ }^{35}$ Poorly educated and beholden to the elite, the other whites in the South had no way to come to their own informed decision about the war. ${ }^{36}$

\footnotetext{
${ }^{34}$ Franklin M. Drew, "The Civil War," in War Papers Read Before the Commandery of the State of Maine, Military Order of the Loyal Legion of the United States vol. II [Military Order of the Loyal Legion of the United States: Maine vol. II] (reprint; Wilmington, NC: Broadfoot Publishing, 1992 [1902]), 313, 314, 318, 320.

${ }^{35}$ Charles H. Sweeney, "Our Friend--The Enemy," in War Sketches and Incidents as Related by the Companions of the Iowa Commandery, Military Order of the Loyal Legion of the United States vol. II
} 
Rather than avoiding the question of slavery, veterans identified it as the mainspring behind the slaveholding elite's attempt to form their own country. Capt. George Sumbardo of the 12th Iowa Infantry Regiment declared that slavery led directly Southern intransigence. He noted that "the Southern planter lived in his elegant mansion remote from city life, surrounded only by his slaves, upon the fruits of whose unremunerated toil he led a life of luxurious indolence... The Southern mind was blindly

[Military Order of the Loyal Legion of the United States: Iowa vol. II] (reprint; Wilmington, NC: Broadfoot Publishing, 1994 [1898]), 479.

${ }^{36}$ This Northern understanding of the war greatly facilitated the spread of the Lost Cause myth. The Lost Cause held that southerners had engaged in a noble battle, rooted in constitutional principles rather than an ardent defense of slavery, and that they had lost because of overwhelming northern numerical supremacy. The Lost Cause also emphasized that the average Confederate soldier had fought not out of self-interest but manly patriotic fervor; the Confederate veteran embodied American patriotism just as much as the northern veteran. This version of history dovetailed with the inclination of Union veterans to see the southern soldiers as essentially honorable. The Slave Power thesis placed the blame on southern leaders, and like the Lost Cause, also minimized the investment that average white southerners had in the institution of slavery. Likewise, as we have seen, the Slave Power thesis often left thorny questions about the morality and importance of slavery aside. For more on the Lost Cause, see: Blight, Race and Reunion; Paul H. Buck, The Road to Reunion 1865-1900 (Boston: Little, Brown, 1937); Gaines M. Foster, Ghosts of the Confederacy: Defeat, The Lost Cause, and the Emergence of the New South, 1865 to 1913 (New York: Oxford University Press, 1987); Gary W. Gallagher and Alan T. Nolan, editors, The Myth of the Lost Cause and Civil War History (Bloomington: University of Indiana Press, 2000); Rollin G. Osterweis, The Myth of the Lost Cause 1865-1900 (New York: Archon Books, 1973); and Charles Reagan Wilson, Baptized in Blood: The Religion of the Lost Cause, 1865-1920 (Athens: University of Georgia Press, 1980). 
ignorant of those powerful forces which both build and destroy nations. It is utterly impossible for a system to be permanent that is based upon selfishness and tyranny." ${ }^{37}$ Veterans used slavery to undercut claims that the Civil War had been a war of southern independence. MOLLUS veterans eagerly claimed the mantle of the Revolutionary generation and pointed out how the Southerners had diverged from the founding principles of the country. Maj. George L. Paddock, who had served in the 12th Illinois Infantry Regiment and the 11th United States Colored Infantry Regiment, drew a direct line between the heroes of 1776 and those of 1861. Secession, he wrote, "ran counter to those tendencies toward a closer and better union, which... had brought together our forefathers from their scattered abodes, and inspired them, whether at Bunker Hill or at Yorktown, at King's Mountain or at Saratoga, to the achievements of a great and noble undertaking. ${ }^{38}$ Bvt. Brig. Gen. James H. Baker, too, thought that slavery distorted the true principles of the Revolution. He took as his example Confederate Gen. Robert E. Lee, who he described as an "apostle of slavery; but behind him ever was the inexorable avenger of wrong." He posited, "Had the Southern soldiers been fired by the spirit of genuine liberty, they would have fled to the hills and mountains [after Appomattox], and fought through generations to maintain freedom. The tradition which floated in the air, from Runnymede to Yorktown, would have sustained and impelled

\footnotetext{
${ }^{37}$ C. L. Sumbardo, "Incidents of Prison Life, with Causes of Confederate Cruelty," in MOLLUS: Minnesota vol. III, 375.

${ }^{38}$ George L. Paddock, "The Beginnings of an Illinois Volunteer Regiment in 1861," in Military Essays and Recollections: Papers Read Before the Commandery of the State of Illinois, Military Order of the Loyal Legion of the United States, vol. II [Military Order of the Loyal Legion of the United States: Illinois vol. II], (reprint; Wilmington, NC: Broadfoot Publishing, 1992 [1894]), 255.
} 
them forever." Lee's surrender at Appomattox showed "the degrading and hideous monster of human slavery...His broken sword was the last defence of slavery. History must forever proclaim that the true hero of the war was he whose intrepid spirit caused the bugles of Liberty to make new melody throughout the world." ${ }^{39}$

Rather than explicitly placing all of the blame for the Civil War upon southern leaders as a poisonous aristocracy, other MOLLUS speakers placed the conflict within the context of United States history. They saw the war as the last chapter in an ongoing struggle to spread republican virtue throughout the world They saw their own role in the struggle as the virtuous soldier who had laid aside selfish concerns in the interest of the common welfare. They drew examples from the Bible and ancient times, tying their own endeavors into an historical chain that stretched back to time immemorial. In doing so, they placed themselves within the context of the volunteer armies of the United States, which unlike all other armies, drew from the bone and sinew of the population. The volunteer fought out of a sense of justice and virtue, not for filthy lucre or because a tyrannical government had forced him to fight. In winning the Civil War, they had accomplished their mission through the destruction of the last impediment that held the United States back from its providential role in the world.

Lt. Francis A. Riddle, who had served in the 130th Illinois Infantry Regiment as well as the 93rd United States Colored Infantry Regiment, took as his topic "The Soldier's Place in Civilization." He engaged in a sweeping overview of armed conflict throughout history, from the travails of the tribes of Judah described in the Old Testament to the wars

\footnotetext{
${ }^{39}$ James H. Baker, "General U.S. Grant--His Military Character and Position in History," MOLLUS: Minnesota vol. IV, 398.
} 
of the ancient Greeks to the rise of the Roman Empire. Riddle drew a parallel between those earlier civilizations and the United States. For Riddle, the lesson of history was that ancient armies enjoyed victory so long as they fought for liberty. He commented pungently: "So much for Greece and Rome. As long as their soldiers drew the sword to defend their firesides and guard their liberties, the nations that sent them forth to battle rose in glory, and their people grew in virtue and strength; and when they waged war even for conquest and plunder, they revelled for a while indeed in puissant splendor." Yet the temporal wealth tarnished, and "their vices and injustice sapped the foundations of the mighty nations their true manhood had established." Out of the ruins of the ancient world arose chivalry, which Riddle described as "the strangest mixture of good and evil, of mercy and cruelty, of selfishness and generosity." Here Riddle began to work in more recent history; rather than an example to be emulated, the ideal of chivalry corrupted. In his view, it was more advanced than the ideals of the ancients, but was not fit for the modern world. He then shifted to discussing the two great revolts against monarchy and chivalry, the American Revolution and the French Revolution. Of the two, Riddle pointed out that only the Americans had respected liberty and justice in their struggle.

Unfortunately, the American Revolution failed to rid the country of a "savage alien of a barbarous age." He continued: "Menaced by the sweet fresh breath of freedom, this alien, slavery rose in malignant fury and poured its wrath upon the nation's life." In Riddle's account, slavery prevented chivalry from being relegated to the past where it belonged. ${ }^{40}$ Capt. Eugene Wilson of the 1st Minnesota Cavalry Regiment held forth on "The Blessings of War." He excused his topic at the start and noted that "it may seem strangely

\footnotetext{
${ }^{40}$ Riddle, Francis A., "The Soldier's Place in Civilization," in MOLLUS: Illinois: Volume II, 523, 533.
} 
out of place to look for blessing amid disasters." But, he told listeners, "the history of the world...shows that from when the sons of God sang together in the morning of time to our own age of boasted civilization, strange modes have been essential to accomplish great and beneficial results." Wilson, like Riddle, placed the preservation of liberty as the only true idea that justified war. Instead of looking at the ancient Greeks and Romans, Wilson drew upon the Crusades for his historical evidence. The Crusaders, while "overshadowed by dense ignorance...brought back new ideas, and their communication with the more learned East enabled them to sow again in Western Europe the seeds of a mental revival that has continued unchecked to our own period." Sent forth by feudalism and the Catholic Church, the Crusaders had, in spite of themselves, found wisdom and knowledge in the Muslim world that they then brought back to lift Europe out of the Dark Ages. Wilson held that this "mental revival" ushered in a new age that swept away the "worst of political systems," which was "feudalism... a system once necessary as the first advance from the savage tribal relation" but "antagonistic to the consolidated governments demanded by advancing civilization." 41

In short, the knowledge acquired during the Crusades sparked the efflorescence of the Enlightenment, leading to the eruption of republican democracy. Wilson traced the path of feudalism from Europe to the slaveholders of the South, seeing them as an impediment to the spread of liberty. The Civil War swept the last vestiges of the Old World out of the New. He concluded that "The chief benefit of the war was, of course,

${ }^{41}$ Eugene M. Wilson, "The Blessings of War," in Glimpses of the Nation's Struggle: A Series of Papers Read Before the Minnesota Commandery of the Military Order of the Loyal Legion of the United States [Military Order of the Loyal Legion of the United States, vol. I] (reprint; Wilmington, NC: Broadfoot Publishing, 1992 [1887]), 167, 170. 
the abolition of negro slavery... a trial of sectional strength was inevitable, and tried it was. The result was emancipation...Greater harmony than ever has been produced between the contending sections, because they have been taught the mutual respect that always results from well-fought fields." ${ }^{42}$

Capt. M. J. Severance of the 10th Minnesota Infantry Regiment also placed the Civil War within a global-historical context. He proclaimed that "We follow the red trail of Alexander, Caesar, and Napoleon across the world, and at the end all we shall find nothing but spent fury and exhausted ambition. Neither constructed a permanent system of any value, righted any wrong, or cleared the pathway for individual or national prosperity." He thought that "Such warriors have done nothing but prostitute the tribunal of war...denying its legitimate office,--that of supreme arbiter of questions of human right in a domain beyond all other human jurisdictions." Severance argued that the sole human right was "liberty." Having argued that only liberty justified war in general, he pivoted to discussing the outcome of the American Revolution. He believed in the promise of the "grandeur of our system of government, whose policy of universal equity suffers no hereditary master to wave his trident over a plebian multitude." Despite the success of the Revolution, "a noxious seed" grew and blossomed into the "Bohun Upas of American politics." With this comment, Severance associated slavery with the poisonous tree that many believed had been the Tree of Knowledge in the Garden of Eden. ${ }^{43}$

Warming to his topic, Severance exhorted that "the tinkling chains of the cottonfields disclosed in sharp relief the glories of exemption from physical toil, and this

\footnotetext{
${ }^{42}$ Wilson, "The Blessings of War," 177.

${ }^{43}$ M. J. Severance, "The Results of War," in MOLLUS: Minnesota: Volume II, 367, 369.
} 
exemption one-half of the country worshipped as the idol of liberty. If it did don the paraphernalia of chivalry, yet that chivalry was the fleeting dream of idealism, and not the development of any noble sentiment or action." Severance than praised the end of slavery because it spread liberty and unified the country. Invoking Roman history, he declared that "no nation can be great where indolence is liberty and human labor is counted serfdom. Since slavery can no longer taunt the toiler's avocation, all will come to know that Cincinnatus advancing Roman eagles was the same Cincinnatus at the plough." Severance finished by quoting Lord Byron's allusive connection of Cincinnatus the Roman and George Washington: "Only yesterday all this people saw the star hanging over the place of the nativity of this republic, and drawn then by a holy impulse they worshipped over its cradle,--a cradle rocked a hundred years ago by 'the first, the last, the best, the Cincinnatus of the West."'44

As all of these accounts made clear, Union veterans looked more to the grand duree of history rather than the immediate consequences of the Civil War within their own country. They told self-satisfied stories that cast their own struggles in grandiose terms: the Union soldier in the Civil War stood among the pantheon of antiquity, a figure of global-historical importance. For the MOLLUS veterans, vindicating republicanism stood as the central act of world history. Because of this, veterans mentioned emancipation and African Americans within their narratives, but saw these matters as somewhat tertiary to the central goal of the war.

Veterans tied emancipation to the Union war effort. They rooted its importance, however, in the benefit that emancipation brought to the northern cause. They often

\footnotetext{
${ }^{44}$ Severance, "The Results of War," 370, 377, 380.
} 
emphasized the pragmatic aspects of emancipation as they saw them, such as using African American soldiers to perform fatiguing duties that white troops liked to avoid, rather than the humanitarian benefits for African Americans. Maj. S. C. Gordon of the 13th Maine Infantry Regiment thought that "had we adopted a policy of using negroes," from the start of the war, "for all fatigue duty we could have saved thousands of our New England boys who died from the effects of it." He resented the influence of "politicians in Washington" who had spent their time engaging in "theoretical politics." Gordon had realized that the war would "end slavery, not by proclamation, but by a general disintegration of the old order of things." As Gordon interpreted it, the Civil War would have led inevitably to emancipation, and the prevarications of the politicians led to unnecessary deaths for white Union troops. Emancipation should have been embarked upon immediately, as the war would inevitably result in the disintegration of the old order of things; delaying only led to more suffering for the true Union patriots. ${ }^{45}$

Similar to Gordon, Brig. Gen. Selden Connor explained that "like most of my comrades, I was not an Abolitionist, but a Lincoln Republican, opposed to the extension of slavery but not advocating a crusade against it. Not that I thought of slavery as other than a blot on our civilization and hindrance to the progress of our country, an institution injudicious alike to slave and master, but love for the Union made its welfare the first consideration." ${ }^{46}$ Connor, as with other veterans, thought of emancipation as a wartime

${ }^{45}$ S. C. Gordon, "Reminiscences of the Civil War from a Surgeon's Point of View," in War Papers Read Before the Commandery of the State of Maine, Military Order of the Loyal Legion of the United States [Military Order of the Loyal Legion of the United States: Maine vol. I] (reprint; Wilmington, NC: Broadfoot Publishing, 1992 [1898]), 137-38.

${ }^{46}$ Selden Connor, "The Boys of 1861," in MOLLUS: Maine vol. I, 327. 
necessity. It had come about not out of any crusade that had led to the Civil War, nor developed as such during the war, but from the ardent desire of the soldiers for the welfare of the Union. Emancipation had emerged as a means to secure the war aim of preserving the Union.

These accounts show that soldiers, even far into the postwar period, remained preoccupied with telling how slavery had led to the Civil War. They saw the institution as an artifact of a previous historical era, one that had dire consequences for the United States. It had arrested the spread of liberty because it allowed a domestic aristocracy to form. This aristocracy, concealing its foul nature beneath the vestments of chivalry, had manipulated the South into secession, plunging a dagger into America's heart. Union soldiers, motivated by the desire to secure liberty--the only legitimate goal of warfare-struck the assassins down. And, following the model of George Washington, who himself walked the path laid out by that noblest of Romans Cincinnatus, they went home having prevailed. The Union could continue on the path of progress that had been ordained through centuries of struggle. The cumulative effects of the appeals to history in the MOLLUS papers stripped from the institution of southern slavery contemporary meaning.

The denial of slavery's immediate, human stakes implicit in the way MOLLUS veterans thought about the war historically is made explicit in the ways that they discussed African Americans. The veterans who presented during MOLLUS meetings often included mention of African Americans in their speeches and papers. Yet these references often failed to accord much recognition to the freedom struggle. Rather, veterans incorporated stories of black people into their narratives in ways that diminished 
or marginalized their participation in the war. They often mentioned African Americans as a way to add some levity to their stories, turning them into objects of ridicule or amazement. Thus, while soldiers fully acknowledged slavery as a baleful influence that had held America back, they failed to extend their consideration to those who had been enslaved. This view had been an outgrowth of their use of the Slave Power conspiracy thesis; seeing the war as a republican struggle against aristocracy elevated its position in world history, equal to the American Revolution in its importance. From this standpoint, emancipation appeared as an ancillary outcome to the war. Whatever had happened during the war with African Americans had been an outgrowth of the primary purpose of the war. Thus, it became easy to describe African American participation in the war, as well as black people in general, as supporting characters in a narrative that centered on the accomplishments and deeds of the MOLLUS soldiers.

In these respects, the veterans of MOLLUS differed somewhat from other veterans. Recent scholarship has shown that the Grand Army of the Republic (GAR), the other major Northern veterans' group following the Civil War, included many African American members. African American participation in the GAR ensured that there would be consideration of the narratives they told about the Civil War, most acutely the memory that their sacrifice during the war had led to emancipation and the promise of equality within the United States. As Barbara A. Gannon has argued, while African American veterans seldom achieved a complete victory over discrimination and exclusion, they made sure that Union veterans heard their voices. At the least, they "creat[ed]...a 
transcendent bond--comradeship--that overcame even the most pernicious social barrier

of their era--race-based separation." ${ }^{47}$

Such recognition of the "transcendent bond" of interracial comradeship is conspicuously absent in the recollections of MOLLUS members. Veterans told of the joy that the enslaved African Americans had shown when the Union troops passed through, striking their shackles from them, but did so in ways that underscored what they saw as the animalistic nature of blacks. Capt. Charles Mitchell of the 7th Ohio Cavalry Regiment remarked that "as much as the chivalry have hated us, in greater degree the blacks rejoiced at our coming." But Mitchell saw little significance in the gratitude of the enslaved. He saw them, instead, as subordinate players in the larger drama of the war. He told listeners that "the boys got much amusement out of the antics of this mass of ebony and wool, this irresponsible, happy-go-lucky throng." ${ }^{48}$ Maj. Eliphalet Rowell, a

${ }^{47}$ Barbara A. Gannon, The Won Cause: Black and White Comradeship in the Grand Army of the Republic (Chapel Hill: University of North Carolina Press, 2011), 7. Other historians of the Grand Army of the Republic have mentioned African American participation in the organization but have argued that any egalitarian gains vanished under the tide of reconciliation. On this, see McConnell, Glorious Contentment, 213-18; and Donald R. Shaffer, After the Glory: The Struggles of Black Civil War Veterans (Lawrence: University Press of Kansas, 2004). Andre Fleche, similar to Gannon, has found that among narratives that the GAR published, "the widespread existence of positive memories of black service provided ammunition for the more radical voices that challenged late-nineteenth-century racism." See Andre Fleche, "'Shoulder to Shoulder as Comrades Tried': Black and White Union Veterans and Civil War Memory," Civil War History Vol. 51, No. 2 (June 2005), 178.

${ }^{48}$ Charles D. Mitchell, "Field Notes of the Selma Campaign," in Sketches of War History 1861-1865:

Papers Prepared for the Commandery of the State of Ohio, Military Order of the Loyal Legion of the United States 1903-1908 vol. VI [Military Order of the Loyal Legion of the United States: Ohio vol. VI], 
paymaster in the regular army, described how African Americans "danced with delight, rolling their eyes, and each other in the sand, with a perfect consciousness of their growing importance." ${ }^{49}$ Capt. Charles Hopkins of the 13th New Jersey Infantry noted "their intense longing for freedom had become more than a passion; it seemed like an uncontrollable frenzy." ${ }^{50}$ Chaplain John S. Sewall of the 8th Massachusetts Militia recalled how he "found frequent amusement in watching their monkey tricks, and especially in listening to their songs and hymns." ${ }^{51}$ The enslaved population, as these soldiers told it, seemed motivated by dangerous passions; freedom resulted in "uncontrollable frenzy," "rolling eyes," and "monkey tricks." Instead of seeing the historical continuum of liberty at work among the enslaved population, veterans saw something quite different. The spread of liberty, for the veterans, only held great importance at the abstract level, where emancipation could be discussed as a necessary waypoint on America's march toward destiny.

edited by Theodore F. Allen, Edward S. McKee, and J. Gordon Taylor (reprint; Wilmington, NC: Broadfoot Publishing, 1992 [1908]), 189.

${ }^{49}$ Eliphalet Rowell, "Six Months in the Military Department of Virginia and North Carolina," in MOLLUS: Maine vol. II, 50.

${ }^{50}$ Charles A. Hopkins, The March to the Sea, in Personal Narratives of the Events in the War of the Rebellion, Being Papers Read before the Rhode Island Soldiers and Sailors Historical Society, vol. V [Military Order of the Loyal Legion of the United States: Rhode Island, vol. V] (reprint; Wilmington, NC: Broadfoot Publishing, 1993 [1885]), 62.

${ }^{51}$ John A. Sewall, "Echoes from Life in Camp," in War Papers Read before the Commandery of the State of Maine, Military Order of the Loyal Legion of the United States, vol. IV [Military Order of the Loyal Legion of the United States: Maine vol. IV] (reprint; Wilmington, NC: Broadfoot Publishing, 1992 [1915]), 84. 
An account by Lt. Col. J. Albert Monroe of Rhode Island showed the same dynamic at work. He informed readers that "the negro has a great weakness for watermelons" and described the time a boat load of watermelons had arrived at the Union supply depot at City Point. At the time, remnants of Brig. Gen. Edward Ferrero's United States Colored Troops (USCT) divisions bivouacked in the area. They acquired most of the shipment. Monroe described what he saw as a "most ludicrous scene" where "instead of cutting the fruit into pieces...they had split each melon in halves...burying their faces in the cavities." He asked his readers to "imagine a thousand negroes, sitting, squatting and lying, on the ground, engaged in eating melons in this manner." For Monroe, the episode indicated how far African Americans diverged from white men. Instead of using utensils and sitting at tables to eat, they tore into the melons any which way they could. He even found the USCT strange in death. After witnessing the attack of the USCT during the Battle of the Crater in Petersburg, Virginia, he recalled that "I had seen thousands of dead white soldiers, but the attitudes and positions assumed by these men in their dying moment truly surprised me." Whereas white troops had died in a dignified manner, the USCT lay scattered about in a way that had surprised him. He further elaborated that "there is hardly any position that the human body is capable of assuming that these forms were not in. ${ }^{52}$

Even when speakers mentioned abolition as an explicit war aim, they often avoided presenting African Americans in the narrative in an active role. Veterans, if they

\footnotetext{
${ }^{52}$ J. Albert Monroe, Reminiscences of the War of Rebellion 1861-5, in Personal Narratives of Events in the War of the Rebellion, Being Papers Read Before the Rhode Island Soldiers and Sailors Historical Society vol. II [Military Order of the Loyal Legion of the United States Rhode Island vol. II] (reprint; Wilmington, NC: Broadfoot Publishing, 1993 [1881]), 486-87, 480.
} 
mentioned abolition, usually portrayed blacks as passive recipients of freedom. The Union soldiers had freed them, and it was up to the formerly enslaved to make something out of that boon. Arthur Edwards, a chaplain in the 1st Michigan Infantry Regiment, recalled, "Freemen...seized the sword to give liberty to others." He thought the Union cause had been ennobled by such philanthropic condescension: the fact that "our human brother was black but heightens the honor, and deifies the heroic unselfishness." He elaborated that Union war aims had been "first, liberty; second, liberty for others; and third, that liberty for our lowly brothers. ${ }^{" 53}$ In his account, Edwards expressed a racist vision of emancipation. Soldiers had gone to war to secure their own liberty and protect the liberty of others. From those goals sprang the third, liberty for African Americans. And liberty for African Americans demonstrated the nobility of the Union cause, for sacrificing toward that "heightens the honor," presumably because blacks were unworthy of liberty. Edwards, writing after the war, might have been influenced by the collapse of the egalitarian experiment of Reconstruction, when resurgent white forces in the South wiped away many of the gains of emancipation. At times, veterans explicitly mentioned reconstruction as an example of how blacks had been unfit for freedom. E. J. Harkness acidly commented that although "North and South, negroes and whites, must share the responsibility" for the failures of Reconstruction, "the fruits of liberty have so far been veritable apples of Sodom" in the hands of blacks. ${ }^{54}$

Despite the fact that no African Americans belonged to the MOLLUS commanderies, the veterans often mentioned the role of African Americans in the Civil

\footnotetext{
${ }^{53}$ Arthur Edwards, "Those Who Fought Without Guns," in MOLLUS: Illinois, vol. I, 449.

${ }^{54}$ E. J. Harkness, "Reflections Concerning the War," in MOLLUS: Illinois, vol. IV, 542.
} 
War. Abdial R. Abbott, a former artillery lieutenant, explained "No account can be generous or just which does not consider the position and conduct of the colored race." 55 Garth W. James, a captain in the famed 54th Massachusetts Infantry Regiment, lectured "I simply want to show you that the negro, with military law and custom, with traditions of a lifetime against him, with chances vastly in favor of ourselves, made a brave fight against an unfair foe, and fought as well as we did." ${ }^{56}$ James H. Rickard, a captain who had served in the 19th United States Colored Infantry Regiment, remarked "The world's standard of heroism is the 'Spartan Greeks at Thermopolae" and that black troops "challenge Greek, Roman, or any other heroism." ${ }^{57}$ James Cobb, who had served with the 96th United States Colored Infantry in Louisiana, told his listeners that black troops "stood by their colors upon every battlefield and in every engagement, without a break in their ranks." He emphasized that he believed "this to have been true of the colored troops

\footnotetext{
${ }^{55}$ Abdial R. Abbott, "The Negro in the War of the Rebellion," in Military Essays and Recollections: Papers Read Before the Commandery of the State of Illinois, Military Order of the Loyal Legion of the United States vol. III [Military Order of the Loyal Legion of the United States: Illinois vol. III] (reprint;

Wilmington, NC: Broadfoot Publishing, 1992 [1899]), 373.

${ }^{56}$ Garth W. James, "The Assault on Fort Wagner," in War Papers: Being Papers Read Before the Commandery of the State of Wisconsin, Military Order of the Loyal Legion of the United States vol. I [Military Order of the Loyal Legion of the United States: Wisconsin vol. I] (reprint; Wilmington, NC: Broadfoot Publishing, 1993 [1891]), 9.

${ }^{57}$ James H. Rickard, Services with Colored Troops in Burnside's Corps, reprinted in Personal Narratives of the Events in the War of the Rebellion, Being Papers Read Before the Rhode Island Soldiers and Sailors Historical Society vol. VIII [Military Order of the Loyal Legion of the United States: Rhode Island vol. VIII] (reprint; Wilmington, NC: Broadfoot Publishing, 1993 [1894]), 33.
} 
generally, upon every battlefield from the Potomac to the Rio Grande. No braver or better soldiers ever wore the uniform of the United States Army or in fact of any other army." ${ }^{58}$ Some members of MOLLUS took a rather sympathetic view of the challenges African Americans faced in transitioning from slavery to freedom to soldier. Henry Freeman, an officer with the 12th United States Colored Infantry Regiment, related how "many of the men were literally clodhoppers, with no ideas of neatness or cleanliness...having only one idea of liberty,--that it meant freedom from all work and care." Despite this fact, he noted that "from slavery to freedom was itself a grand transition; but to become Union soldiers was still a higher promotion, exceeding their most sanguine hopes,--a privilege estimated at its full value." Freeman concluded his paper: "Who will say that men who fought and suffered as did these colored soldiers have not fairly earned for themselves and their race the freedom which the war gave them. Soldierly courage and self-devotion recognize no distinction of color or race." ${ }^{59}$

William H. Armstrong, who served with the 8th United States Colored Heavy Artillery, related "we hear much from Anglo-Saxon lips of the glorious part men of their proud lineage played...but there is another race fairly well represented in the glorious action... whose minds may not retain its events so vividly, and whose lips are not formed for such rounded periods in song and story." He noted how during the Civil War, the

\footnotetext{
${ }^{58}$ John C. Cobb, "One Year of My More Than Three Years' Service with the Army of the Gulf," in War Papers Read Before the Commandery of the State of Maine, Military Order of the Loyal Legion of the United States vol. III [Military Order of the Loyal Legion of the United States: Maine vol. III] (reprint; Wilmington, NC: Broadfoot Publishing, 1992 [1908]), 305.

${ }^{59}$ Henry V. Freeman, "A Colored Brigade in the Campaign and Battle of Nashville," in MOLLUS: Illinois vol. II, 400, 421.
} 
black soldiers "came from the degradation and darkness of slavery to the glorious brightness of liberty, with scarcely a season of twilight intervening" and "neither will any just and patriotic person withhold from him the portion of praise he fully earned by his valor and good conduct in the great and holy struggle for human liberty and free government in which he was so prominent a figure." 60

More common, however, were accounts by men such as Col. Thomas J. Morgan, who had served in the 70th Illinois Infantry Regiment and the 14th United States Colored Infantry Regiment, who wrote "These men, though black in skin, had men's hearts, and only needed right handling to develop into magnificent soldiers." Morgan closed his paper by commenting that "if the records of their achievements could be put into such shape that they could be accessible to the thousands of colored youth in the South, they would kindle in their young minds an enthusiastic devotion to liberty and manhood." $\mathrm{He}$ had delivered praise in general terms, but that praise bore a condescending undercurrent. Blacks needed "right handling" in order to develop into real men; the "colored youth in the South" still needed tutelage in order to come to "an enthusiastic devotion to liberty and manhood." ${ }^{61}$

Other soldiers described how the supposed traits of the African American rendered him particularly adept at military service. Capt. William Eliot Furness of the 3rd United States Colored Infantry Regiment and the 45th United States Colored Infantry

\footnotetext{
${ }^{60}$ William H. Armstrong, "The Negro as Soldier," in War Papers Read Before the Indiana Commandery Military Order of the Loyal Legion of the United States [Military Order of the Loyal Legion of the United States: Indiana] (reprint; Wilmington, NC: Broadfoot Publishing, 1992 [1898]), 316, 318-19.

${ }^{61}$ Thomas J. Morgan, "Reminiscences of Service with Colored Troops in the Army of the Cumberland, 1863-1865," in MOLLUS: Rhode Island: Volume V, 80, 118.
} 
Regiment spoke of how at the start of the war, "if the negro was thought of at all, it was only as the firebrand that had caused the conflagration, the accursed thing that had created enmity and bitterness between the two sections." He noted that sentiment across the North changed as the war dragged on, and that when authorities finally raised black troops, they found them particularly suited to the life of a soldier. Furness explained that "their long training as servants made them obedient and docile to their officers, and they were almost never guilty of insubordination... although it was perhaps difficult at first to convince them of the necessity of obedience to the orders of their non-commissioned officers, who were of their own race, and whom they seemed to find hard to consider as superiors." Commenting upon his own men, Furness praised them for their cleanliness, obedience, and bravery. He thought them "fairly equal in all respects to the soldier of other race and color." Any deficiencies he chalked up to "their long-continued servitude and lack of education" that was "naturally inferior to the educated white citizens of the North, yet in other respects they were, from that very inferiority, better fitted to fill the ranks of a regiment." ${ }^{62}$

Abdial Abbott echoed Furness. He explained that enslaved blacks knew "that success to the Union cause would fix his status as a freeman for all time" and that "his peculiar characteristics, the result partly of long years of servitude, furnished to the negro both a motive and a spur." Abbott continued that "unquestioned obedience to authority had been instilled in his mind for generation... In his mental outfit he had considerable self-esteem coupled with a desire for the approval of others, enough to arouse him to action and to bring out his soldierly qualities when under the eye of the white man, whom

${ }^{62}$ William Eliot Furness, "The Negro as Soldier," in MOLLUS: Illinois vol. II, 457, 468, 469-70, 486. 
he regarded as his superior in advantages as well as in intellect." Abbott also elaborated that "the white American soldier is first and foremost a civilian, and has a civilian's detestation of cold steel. The negro of that period, however, in common with the Russian and the North African, developed into an absolutely cold-blooded soldier,--the best material for the rank and file of a regular army." Thus, the racial characteristics of blacks gave them an advantage in warfare. ${ }^{63}$

An officer of the 92nd Illinois Infantry Regiment and the 12th United States Colored Infantry, Henry Norton, observed "I found [blacks] eager to learn, very attentive and enthusiastic. Fond of show and glitter, they received their arms and accoutrements, with delight. In drill they were apt scholars and particularly so in the manual of arms." He judged that "the experiment of arming the colored man, as it came under my observation, was a complete and even marvelous success. They displayed great natural capacities for acquiring the duties of a soldier." Despite these encomiums, Norton thought them "in intelligence and tenacity, they were inferior, and no wise general would have counted a corps of them equal, man for man, in a great protracted battle, to a like number of white soldiers." ${ }^{64}$ Capt. J. M. Addeman, who had served in the 10th Rhode Island Infantry Regiment and the 8th United States Colored Heavy Artillery Regiment likewise considered that the "mimic talents of our men, led to the performance of a variety of

\footnotetext{
${ }^{63}$ Abbott, "The Negro in the War of the Rebellion," 374, 383.

${ }^{64}$ Henry Allyn Norton, "Colored Troops in the War of the Rebellion," in Glimpses of the Nation's Struggle: Papers Read Before the Minnesota Commandery of the Military Order of the Loyal Legion of the United States, 1897-1902, 5th ser. [Military Order of the Loyal Legion of the United States: Minnesota vol. V (reprint; Wilmington, NC: Broadfoot Publishing, 1992 [1903]), 68, 72.
} 
entertainments, and in their happy-go-easy dispositions, their troubles set very lightly on them. Their extravagancies of expression were by no means an unremarkable feature." 65 Brig. Gen. Selden Connor, while generally laudatory of the United States Colored Troops, could not refrain from comparing black Americans to Africans. He acknowledged, "In the War for the Union, the negro, if not actually the 'teterrima causes belli,' was a very close approximation of it." He went on to note that "the fighting proclivity is as strongly developed in his blood as in that of any other race...The Zulu phalanxes that stood out against the soldiers of the British empire, and slew the heir of Napoleon, were as brave and well-disciplined as any troops that ever marched into battle." He gushed that "The American citizen of African descent may well take pride in the part the men of his race bore in the 'war for the Union' and in the manliness displayed by them on so many bloody fields." He concluded that "together they gave to the nation and the world undying proof that Americans of African descent possess the pride, courage, and devotion of the patriot soldier." 66

The veterans of MOLLUS acknowledged the role of African Americans within the Civil War, as well as the importance of emancipation. But these considerations took on a decidedly secondary importance to the defeat of the Slave Power; some soldiers considered emancipation a useful tool with which to accomplish the goal. Soldiers who belonged to the MOLLUS could acknowledge that African Americans had served with

\footnotetext{
${ }^{65}$ J. M. Addeman, "Reminiscences of Two Years with the Colored Troops," in MOLLUS: Rhode Island: Volume II, 245.

${ }^{66}$ Selden Connor, "The Colored Troops," in MOLLUS: Maine vol. III, 61, 79, 80, 82.
} 
honor and distinction as soldiers, but they also exhibited typical prejudices and predilections when discussing their participation in the Civil War.

Even far into the postwar period, Union veterans refused to remain silent on the causes of the Civil War. They told a self-congratulatory story of the war, one that emphasized their role in events that had been of momentous importance to the world. To establish that importance, they had to revisit the Slave Power theory, and demonstrate how their struggle against the Confederacy had led to increased liberty. Their frame of reference for this liberty remained somewhat abstract; slavery had corrupted liberty because it had threatened American republicanism. By eradicating slavery, the Union had swept away the Slave Power. While veterans acknowledged the role of African Americans in the war, they gave only slight consideration for their advancement during and after the war. Without African Americans among their membership, the veterans of MOLLUS faced little pressure to incorporate their narratives into their own. And in this, the MOLLUS veterans demonstrated the persistent memory of the Union cause; they had gone to war to shatter the Slave Power. Victorious, they trumpeted that achievement from the immediate postwar period until their deaths. 


\section{Conclusion}

The Slave Power conspiracy thesis died with the veterans who had held it. The Civil War itself had convinced many northerners that a slaveholding oligarchy had sought, at the least, to destroy the Union, if not enslave the North. Before the war, the Slave Power conspiracy had been a fear of many, but could be discounted as partisan posturing on the part of the Republicans. But the war made what had been a rhetorical device--simply another paranoid delusion in the style of anti-Masonry--into a convincing historical truth. As time passed, however, subsequent generations of Americans would place less emphasis on the Slave Power conspiracy. To them, the war would appear more as a struggle over economics; a struggle of agrarian freeholders against an industrializing leviathan; or the last gasp of the states against the ever-enlarging Federal government. One anecdote captures some of this shift. ${ }^{1}$

In 1895, a volume entitled Hero Tales appeared at booksellers across the nation. Penned by New York City police commissioner Theodore Roosevelt and Massachusetts Senator Henry Cabot Lodge, the book aimed "to tell in simple fashion the story of some Americans who showed that they knew how to live and how to die." ${ }^{2}$ They sought to remind "young Americans" of "thrift, industry, obedience to law, and intellectual

\footnotetext{
${ }^{1}$ See Thomas J. Pressley, Americans Interpret Their Civil War (Princeton: Princeton University Press, 1954).

${ }^{2}$ Theodore Roosevelt and Henry Cabot Lodge, Hero Tales from American History: Or the Story of Some Americans Who Showed That They Knew How to Live and How to Die (New York: Charles Scribner's Sons, 1906), Ix.
} 
cultivation" through accounts of famous Americans. Roosevelt, doubtlessly influenced by his Southern mother, chose to write upon people and subjects that included Daniel Boone, George Rogers Clark, the battle of King's Mountain, the Alamo, the death of Thomas J. "Stonewall" Jackson, and Pickett's Charge. Lodge, for his part, picked topics more germane to New England, including John Quincy Adams, Francis Parkman, and Robert Gould Shaw.

Lodge, born in 1850, had been a child during the years of the war. But he had imbibed some of the rhetoric of the time. He, rather than Roosevelt, contributed an essay on Abraham Lincoln. In his brief discussion of the wartime president, Lodge pointed out that the war had been an attempt at the "dissolution of the Union by the slave power" which "meant not only the destruction of an empire, but the victory of the forces of barbarism. ${ }^{3}$ He placed the blame for the war upon the slaveholding oligarchy, victory over which had shattered an internal empire.

Roosevelt, though born in 1858 , had not been quite old enough to take in the spirit of the times, as had Lodge. Roosevelt emphasized that the Civil War had left "terrible and heartrending memories" but that it also gave "North and South... a common fund of glorious memories." In his telling, all Americans were "richer for valor displayed by those who fought so valiantly for the right, and by those who, no less valiantly, fought for what they deemed the right." ${ }^{4}$ Absent, of course, was a clear acknowledgment that the leaders of the South had led it to war. Instead, Roosevelt emphasized the shared experience of the North and South and the heroism both sides had demonstrated.

\footnotetext{
${ }^{3}$ Ibid., 284.

${ }^{4}$ Ibid., 185 .
} 
But Roosevelt's heroic soldiers, both North and South, had been embedded in the Slave Power thesis during the war. The thesis held that southerners had been corrupted, beguiled, and bamboozled by their leaders. Such a view excused the southern ranks from complicity in secession. Rather than an innovation, Roosevelt's idea of common heroism was a vestige of the Slave Power conspiracy thesis. Because the southern aristocracy had been toppled, it made little sense to continue to harp on their baleful influence. And because slavery as an institution, but not the enslaved African Americans themselves, had been central to the Slave Power thesis, it was possible to cast the war as a conflict between "North and South" that gave a united America "a common fund of glorious memories." By defining the war in terms of the subversion of white democracy by white men, the Slave Power thesis allowed Americans to talk about the war without being forced to consider the struggles of African Americans during Reconstruction. 


\section{Bibliography \\ $* * * * * * * * * * * * * * * * * * * *$}

\section{Primary Sources}

\section{Newspapers}

Connecticut

New Haven Daily Palladium

Illinois

Chicago Tribune

New York

New York Herald

New York Tribune

\section{Books and Articles}

Abbott, Abdial R. "The Negro in the War of the Rebellion." In Military Essays and Recollections: Papers Read Before the Commandery of the State of Illinois, Military Order of the Loyal Legion of the United States, vol. III, 373-384. Chicago: The Dial Press, 1899. Reprint, Wilmington, NC: Broadfoot Publishing, 1992.

Acken, J. Gregory, ed. Inside the Army of the Potomac: The Civil War Experience of Captain Francis Adams Donaldson. Mechanicsburg, PA: Stackpole Books, 1998.

Adams, Ida Bright, ed. "The Civil War Letters of James Rush Holmes." The Western Pennsylvania Historical Magazine 44 no. 2 (June 1961): 105-127.

Addeman, J. M. Reminiscences of Two Years with the Colored Troops. Providence: N. Bangs Williams \& Co., 1880. In Personal Narratives of the War of the Rebellion, Being Papers Read before the Rhode Island Soldiers and Sailors Historical Society, vol. II. Wilmington, NC: Broadfoot Publishing, 1993.

Aldrich, C. Knight, ed. Quest for a Star: The Civil War Letters and Diaries of Colonel Francis T. Sherman of the 88th Illinois. Knoxville: University of Tennessee Press, 1999.

Andersen, Mary Ann, ed. The Civil War Diary of Allen Morgan Geer, Twentieth Regiment, Illinois Volunteers. Denver: Robert C. Appleman, 1977.

Arden, Linda Foster. Letters from the Storm: The Intimate Letters of Lt. J. A. H. Foster, 155th Pennsylvania Volunteers, ed. Walter L. Powell. Chicora, PA: Mechling Bookbindery, 2010.

Armstrong, William H. "The Negro as Soldier." In War Papers Read Before the Indiana 
Commandery, Military Order of the Loyal Legion of the United States, 316-33. Indianapolis: The Commandery, 1898. Reprint, Wilmington, NC: Broadfoot Publishing, 1992.

Athearn, Robert G, ed. "The Civil War Diary of John Wilson Phillips." The Virginia Magazine of History and Biography 62 no. 1 (January 1954): 95-123.

Bahde, Thomas, ed. The Story of My Campaign: The Civil War Memoir of Francis T. Moore, Second Illinois Cavalry. With a foreword by Michael Fellman. DeKalb: Northern Illinois University Press, 2011.

Baker, James H. "General U.S. Grant--His Military Character and Position in History." In Glimpses of the Nation's Struggle: Papers Read Before the Minnesota Commandery of the Military Order of the Loyal Legion of the United States, 1892-1897, 4th Series, 379-400. St. Paul: H. L. Collins, 1989. Reprint, Wilmington, NC: Broadfoot Publishing, 1992.

Banasik, Michael E., ed. Duty, Honor, and Country: The Civil War Experiences of Captain William P. Black, Thirty-Seventh Illinois Infantry. Iowa City: Camp Pope Bookshop, 2006.

Barr, Thomas F. "Costs and Compensations of the War." In Military Essays and Recollections: Papers Read Before the Commandery of the State of Illinois, Military Order of the Loyal Legion of the United States, Vol. I, 519-28. Chicago: A. C. McClurg and Company, 1891. Reprint, Wilmington, NC: Broadfoot Publishing, 1992.

Benedict, George G. War Paper No. 4, Vermont Commandery of the Loyal Legion, Read March 14, 1893: The Element of Romance in Military History. In Vermont War Papers and Miscellaneous States Papers and Addresses for the Military Order of the Loyal Legion of the United States, 59-77. Wilmington, NC: Broadfoot Publishing, 1994.

Beaudry, Louis N. Historic Records of the Fifth New York Cavalry, First Ira Harris Guard, Its Organization, Marches, Raids, Scouts, Engagements, and General Services During the Rebellion of 1861-1865, with Observations of the Author by the Way, Giving Sketches of the Armies of the Potomac and of the Shenandoah. Also, Interesting Accounts of Prison Life and of the Secret Service. Complete Lists of Its Officers and Men. Albany: S. R. Gray, 1865.

-. Records of the Fifth New York Cavalry, First Ira Harris Guard, Its Organization, Marches, Raids, Scouts, Engagements, and General Services During the Rebellion of 1861-1865, with Observations of the Author by the Way, Giving Sketches of the Armies of the Potomac and of the Shenandoah. Also, Interesting Accounts of Prison Life and of the Secret Service. Complete Lists of Its Officers and Men. 2d Ed. Albany: S. R. Gray, 1865. 
Records of the Fifth New York Cavalry, First Ira Harris Guard, Its Organization, Marches, Raids, Scouts, Engagements, and General Services During the Rebellion of 1861-1865, with Observations of the Author by the Way, Giving Sketches of the Armies of the Potomac and of the Shenandoah. Also, Interesting Accounts of Prison Life and of the Secret Service. Complete Lists of Its Officers and Men. 3d Ed., enlarged. Albany: J. Munsell, 1868.

Records of the Fifth New York Cavalry, First Ira Harris Guard, Its

Organization, Marches, Raids, Scouts, Engagements, and General Services During the Rebellion of 1861-1865, with Observations of the Author by the Way, Giving Sketches of the Armies of the Potomac and of the Shenandoah. Also, Interesting Accounts of Prison Life and of the Secret Service. Complete Lists of Its Officers and Men. 4th Ed., enlarged. Albany: J. Munsell, 1874.

---------.War Journal of Louis N. Beaudry, Fifth New York Cavalry: The Diary of a Union Chaplain Commencing February 16, 1863, ed. Richard E. Beaudry. Jefferson, NC: McFarland, 1996.

Beasecker, Robert, ed. "I Hope to Do My Country Service": The Civil War Letters of John Bennitt, M.D., Surgeon, 19th Michigan Infantry. With a foreword by William M. Anderson. Detroit: Wayne State University Press, 2005.

Bee, Robert L., ed. The Boys from Rockville: The Civil War Narratives of Sgt. Benjamin Hurst, Company D, 14th Connecticut Volunteers. Knoxville: University of Tennessee Press, 1998.

Beecher, Harris. History of the 114th Regiment N.Y.S.V. Where It Went, What It Saw, and What It Did. Norwich: J.F. Hubbard, Jr., 1866.

Billings, John D. Hardtack and Coffee: Or, The Unwritten Story of Army Life. Boston: George M. Smith, 1887.

Bird, Kermit Molyneux, ed. Quill of the Wild Goose: Civil War Letters and Diaries of Private Joel Molyneux, 141st Pennsylvania Volunteer Infantry. Shippensburg, PA: Burd Street Press, 1996.

Black, Wilfred W., ed. "Civil War Letters of E. N. Boots, Virginia 1862." The Virginia Magazine of History and Biography 69 no. 2 (April 1961): 194-209.

Blackburn, George M., ed. "Dear Carrie...": The Civil War Letters of Thomas N. Stevens. Mount Pleasant, MI: Clarke Historical Library, 1984.

Blair, William Allan, ed. A Politician Goes to War: The Civil War Letters of John White Geary. University Park: Pennsylvania State University Press, 1995. 
Bliss, George N. Prison Life of Lieut. James M. Fales. Providence: N. Bangs Williams, 1882.

Bohrnstedt, Jennifer Cain, ed. Soldiering with Sherman: The Civil War Letters of George F. Cram. Introduction by Orville Vernon Burton. DeKalb: Northern Illinois University Press, 2000.

While Father is Away: The Civil War Letters of William H. Bradbury. Comp. by Kassandra R. Chaney. Lexington: University Press of Kentucky, 2003.

Boudrye, Louis N. Historic Records of the Fifth New York Cavalry...See: Beaudry, Louis

[Boyer, Earl E., ed.] Civil War Diaries of Capt. Albert Heffley and Lt. Cyrus P. Heffley, Company F-142nd Regt. Penna. Vol. Army of the Potomac. Apollo, PA: Closson Press, 2000.

Brady, James P., comp. Hurrah for the Artillery! Knap's Independent Battery "E", Pennsylvania Light Artillery. Gettysburg: Thomas Publications, 1992.

[Brown, E. R.] The Twenty-Seventh Indiana Volunteer Infantry in the War of the Rebellion 1861 to 1865 First Division 12th and 20th Corps: A History of Its Recruiting, Organization, Camp Life, Marches and Battles, Together with a Roster of the Men Composing It, and the Names of All Those Killed in Battle or Who Died of Disease, and as Far As Can Be Known, of Those Who Were Wounded. Monticello, IN: n.p., [1899].

Bumbera, Marlene C., comp. The Civil War Letters of Cpl. John H. Strathern, Eighth Pennsylvania Reserve Volunteer Corps. Apollo, PA: Closson Press, 1994.

Byrne, Frank L., ed. Uncommon Soldiers: Harvey Reid and the 22nd Wisconsin March with Sherman. Knoxville: University of Tennessee Press, 2001.

Cairnes, J. E. The Slave Power: Its Character, Career, \& Probably Designs: Being an Attempt to Explain the Real Issues Involved in the American Contest. London: Parker, Son \& Bourn, 1862.

Calkins, E. A. "History of the Loyal Legion." In War Papers: Being Papers Read Before the Commandery of the State of Wisconsin, Military Order of the Loyal Legion of the United States, vol. III, 343-52. Milwaukee: Commandery of the State of Wisconsin, 1903. Reprint, Wilmington, NC: Broadfoot Publishing, 1993.

Carnahan, James R. "Personal Recollections of Chickamauga." In Sketches of War History, 1861-1865: Papers Read Before the Ohio Commandery of the Military Order of the Loyal Legion of the United States, 1883-1886, Vol. I, 401-22. Cincinnati: Robert Clarke \& Co., 1888. Reprint, Wilmington, NC: Broadfoot Publishing, 1991. 
Chamberlain, Joshua L. "America's First President." In Military Essays and Recollections of the Pennsylvania Commandery, Military Order of the Loyal Legion of the United States: Volume 1: February 22, 1886-May 6, 1903, comp. Michael A. Cavanaugh, 1-30. Wilmington, NC: Broadfoot Publishing, 1995.

Chamberlin, William H. History of the Eighty-First Regiment Ohio Infantry Volunteers During the War of the Rebellion. Cincinnati: Gazette Steam-Printing House, 1865 .

Chisman, James A., ed. 76th Regiment Pennsylvania Volunteer Infantry Keystone Zouaves: The Personal Recollections 1861-1865 of Sergeant John A. Porter Company " $B$ ". Wilmington, NC: Broadfoot Publishing, 1988.

Clark, James H. The Iron Hearted Regiment: Being an Account of the Battles, Marches and Gallant Deeds Performed by the 115th Regiment N.Y. Vols., Also a List of the Dead, Wounded, an Account of Hundreds of Brave Men Shot on a Score of Hard Fought Fields of Strife, a Complete Statement of Harper's Ferry Surrender, Sketches of the Officers, a History of the Flags and Those Who Bore Them, Together with Touching Incidents, Thrilling Adventures, Amusing Scenes, Etc., Etc., Etc. Albany: J. Munsell, 1865.

Cobb, John C. "One Year of My More Than Three Years' Service with the Army of the Gulf." In War Papers Read Before the Commandery of the State of Maine, Military Order of the Loyal Legion of the United States, vol. III, 296-305. Portland: LaFavor Tower Company, 1908. Reprint, Wilmington, NC: Broadfoot Publishing, 1992.

Coe, David, ed. Mine Eyes Have Seen the Glory: Combat Diaries of Union Sergeant Hamlin Alexander Coe. Rutherford, NJ: Fairleigh Dickinson University Press, 1975.

The Commemoration of the Lincoln Centenary by the Ohio Commandery of the Military Order of the Loyal Legion of the United States at Their Headquarters February 12, 1909. N.p., n.d. In Sketches of War History 1861-1865: A Compilation of Miscellaneous Papers Compiled for the Ohio Commandery of the Loyal Legion February 1885-February 1909, 283-313. Wilmington, NC: Broadfoot Publishing, 1993.

Connor, Selden. "The Boys of 1861." In War Papers Read Before the Commandery of the State of Maine, Military Order of the Loyal Legion of the United States vol. I, 323-43. Portland, ME: Thurston Print, 1898. Reprint, Wilmington, NC: Broadfoot Publishing, 1992.

----------. "The Colored Troops." In In War Papers Read Before the Commandery of the 
State of Maine, Military Order of the Loyal Legion of the United States, vol. III, 61-82. Portland: LaFavor Tower Company, 1908. Reprint, Wilmington, NC: Broadfoot Publishing, 1992.

Conyngham, D. P. The Irish Brigade and Its Campaigns: With Some Account of the Corcoran Legion, and Sketches of the Principal Officers. New York: William McSorley \& Co., 1867.

Crane, William. "Bugle Blasts." In Sketches of War History, 1861-1865: Papers Read Before the Ohio Commandery of the Military Order of the Loyal Legion of the United States, 1883-1886, Vol. I, 233-51. Cincinnati: Robert Clarke \& Co., 1888. Reprint, Wilmington, NC: Broadfoot Publishing, 1991.

Cudworth, William H. History of the First Regiment (Massachusetts Infantry), from the 25th of May, 1861, to the 25th of May, 1864, Including Brief References to the Operations of the Army of the Potomac. Boston: Walker, Fuller, and Company, 1866.

Curtis, Oscar F., ed. The Personal Letters of Captain Joseph Willis Young, 97th Regiment Indiana Volunteers, 4th Division 15th A.C., Army of the United States, Civil War. Monroe: Monroe County Historical Society, 1962.

Davenport, Alfred. Camp and Field Life of the Fifth New York Volunteer Infantry (Duryee Zouaves). New York: Dick and Fitzgerald, 1879.

Davidson, Henry M. History of Battery A, First Regiment Ohio Vol. Light Artillery. Milwaukee: Daily Wisconsin Print House, 1865.

Davis, William W. H. History of the 104th Pennsylvania Regiment, from August 22nd, 1861 to September 30th, 1864. Philadelphia: Jas. B. Rodgers, 1866.

Day, D. L. My Diary of Rambles with the 25th Mass. Volunteer Infantry, with Burnside's Coast Division; 18th Army Corps; and Army of the James. Milford, MA: King \& Billings, 1884.

Denison, Frederic. Shot and Shell: The Third Rhode Island Heavy Artillery in the Rebellion, 1861-1865. Providence: Third R.I.H. Art. Vet. Association, 1879.

Dennis, John B. "March of the Sixth Massachusetts Through Baltimore." In Civil War Sketches and Incidents: Papers Read by Companions of the Commandery of the State of Nebraska, Military Order of the Loyal Legion of the United States, 122140. Omaha: The Commandery, 1902. Reprint, Wilmington, NC: Broadfoot Publishing, 1992.

Dodge, William Sumner. A Waif of the War: or, The History of the Seventy-Fifth Illinois 
Infantry, Embracing the Entire Campaigns of the Army of the Cumberland. Chicago: Church \& Goodman, 1866.

Doyle, Julian, John David Smith, and Richard M. McMurry, eds. This Wilderness of War: The Civil War Letters of George W. Squier, Hooiser Volunteer. Knoxville: University of Tennessee Press, 1998.

Drew, Franklin. "The Civil War." In War Papers Read Before the Commandery of the State of Maine, Military Order of the Loyal Legion of the United States, Vol. II, 311-22. Portland, ME: Lefavor-Tower Company, 1902. Reprint, Wilmington, NC: Broadfoot Publishing, 1992.

Duncan, Russell, ed. Blue-Eyed Child of Fortune: The Civil War Letters of Robert Gould Shaw. Athens: University of Georgia Press, 1992.

Dunlap, Leslie W., ed. "Your Affectionate Husband, J.F. Culver": Letters Written During the Civil War. With notes by Edwin C. Bearss. Iowa City: Friends of the U niversity of Iowa Libraries, 1978.

Duram, James C. and Eleanor A. Duram, ed. Soldier of the Cross: The Civil War Diary and Correspondence of Rev. Andrew Jackson Hartsock. Manhattan, KS: Military Affairs/Aerospace Historian, 1979.

Eden, Robert C. The Sword and the Gun: A History of the 37th Wis. Volunteer Infantry, from its First Organization to its Final Muster Out. Madison: Atwood \& Rublee, 1865.

Edwards, Arthur. "Those Who Fought Without Guns." In Military Essays and Recollections: Papers Read Before the Commandery of the State of Illinois, Military Order of the Loyal Legion of the United States, Vol. I, 441-52. Chicago: A. C. McClurg and Company, 1891. Reprint, Wilmington, NC: Broadfoot Publishing, 1992.

Elder, Donald, III, ed. A Damned Iowa Greyhound: The Letters of William Henry Harrison Clayton. Iowa City: University of Iowa Press, 1998.

Emilio, Luis F. A Brave Black Regiment: The History of the 54th Massachusetts, 186365. New introduction by Gregory J. W. Urwin. Boston: Boston Book Company, 1894. Reprint, New York: Da Capo, 1995.

Emmerson, James A. A Record of the Twenty-Third Regiment Mass. Vol. Infantry in the War of the Rebellion 1861-1865 with Alphabetical Roster, Company Rolls; Portraits; Maps; Etc. Boston: William Ware, 1886.

Fatout, Paul, ed. Letters of a Civil War Surgeon. West Lafayett, IN: Purdue University Press, 1996. 
[Fiske, Joseph E.] War Letters of Capt. Joseph E. Fiske [Harvard, '61]: Written to His Parents During the War of the Rebellion from Andover Theological Seminary and Encampments in North Carolina and from Southern Prisons. Wellesley: The Magnus Press, n.d.

Fleharty, Stephen. Our Regiment, a History of the 102d Illinois Infantry Volunteers, With Sketches of the Atlanta Campaign, the Georgia Raid, and the Campaign of the Carolinas. Chicago: Brewster \& Hanscom, 1865.

Flower, Milton E., ed. Dear Folks at Home: The Civil War Letters of Leo W. And John I. Faller with an Account of Andersonville. Carlisle: Cumberland County Historical Society and Hamilton Library Association, 1963.

Floyd, Fred C. History of the Fortieth (Mozart) Regiment New York Volunteers, which was Composed of Four Companies from New York, Four Companies from Massachusetts, and Two Companies from Pennsylvania. Boston: F. H. Gilson, 1909.

Freeman, Henry V. "A Colored Brigade in the Campaign and Battle of Nashville." In Military Essays and Recollections: Papers Read Before the Commandery of the State of Illinois, Military Order of the Loyal Legion of the United States, vol. II, 399-421. Chicago: A. C. McClurg and Company, 1894. Reprint, Wilmington, NC: Broadfoot Publishing, 1992.

Frymoyer, Curtis, ed. "The Civil War Letters of Henry Rice and James Nolan." The Cedar County Historical Review (June 1961), 1-21.

Furness, William Eliot. "The Negro as Soldier." In Military Essays and Recollections: Papers Read Before the Commandery of the State of Illinois, Military Order of the Loyal Legion of the United States, vol. II, 457-87. Chicago: A. C. McClurg and Company, 1894. Reprint, Wilmington, NC: Broadfoot Publishing, 1992.

Gage, Moses D. From Vicksburg to Raleigh; or, a Complete History of the Twelfth Regiment Indiana Volunteer Infantry, and the Campaigns of Grant and Sherman, with an Outline of the Great Rebellion. Chicago: Clarke \& Co, 1865.

Gates, Arnold, ed. The Rough Side of War: The Civil War Journal of Chesley A. Mosman. Garden City, NY: Basin Publishing, 1987.

Gavin, William Gilfillan, ed. Infantryman Pettit: The Civil War Letters of Corporal Frederick Pettit. New York: Avon Books, 1991.

George, W. J. "Church Built at Petersburg by Engineers During the Civil War." Professional Memoirs Corps of Engineers, United States Army and Engineer Department at Large 4 (1912): 521-22. 
Gordon, S. C. "Reminiscences of the Civil War from a Surgeon's Point of View." In War Papers Read Before the Commandery of the State of Maine, Military Order of the Loyal Legion of the United States vol. I, 129-144. Portland, ME: Thurston Print, 1898. Reprint, Wilmington, NC: Broadfoot Publishing, 1992.

Graham, Matthew J. The Ninth Regiment New York Volunteers (Hawkins Zouaves): Being a History of the Regiment and Veteran Association from 1860 to 1900. New York: E.P. Corby \& Co., 1900.

Grimsley, Mark and Todd D. Miller, eds. The Union Must Stand: The Civil War Diary of John Quincy Adams Campbell, Fifth Iowa Volunteer Infantry. Knoxville: University of Tennessee Press, 2000.

Haas, Ralph. Dear Esther: The Civil War Letters of Private Aungier Dobbs Centerville, Pennsylvania, Company "A", The Ringgold Cavalry Company, 22nd Pennsylvania Cavalry, June 29, 1861 to October 31, 1865, ed. Philip Insely. Apollo, PA: Closson Press, 1991.

[Haines, Zenas T.] Letters from the Forty-Fourth Regiment M.V.M.: A Record of the Experience of a Nine Months' Regiment in the Department of North Carolina in 1862-3. Boston: Herald Job Office, 1863.

Hammond, Mary Acton, ed. "'Dear Mollie': Letters of Captain Edward A. Acton to His Wife, 1862." Pennsylvania Magazine of History and Biography 89 no. 1 (January 1965): 3-51.

Hanaburgh, D. H. History of the One Hundred and Twenty-Eighth Regiment, New York Volunteers (U.S. Infantry) in the Late Civil War. Pokeepsie [sic]: n.p., 1894.

Hannaford, G. A. "The Loyal Legion." In War Sketches and Incidents as Related by Companions of the Iowa Commandery of the Military Order of the Loyal Legion of the United States, vol. I, 316-21. Des Moines: Press of P. C. Kenyon, 1893. Reprint, Wilmington, NC: Broadfoot Publishing, 1994.

Hanson, John W. Historical Sketch of the Old Sixth Regiment of Massachusetts Volunteers During Its Three Campaigns, 1861, 1862, 1863, and 1864: Containing a History of the Several Companies Previous to 1861, and the Names and Military Record of Each Man Connected with the Regiment During the War. Boston: Lee and Shepard, 1866.

Harkness, E. J. "Reflections Concerning the War." In Military Essays and Recollections: Papers Read Before the Commandery of the State of Illinois, Military Order of the Loyal Legion of the United States, Vol. IV, 522-43. Chicago: Cozzens \& Beaton, 1907. Reprint, Wilmington, NC: Broadfoot Publishing, 1992. 
Hayes, Rutherford B. "The Loyal Legion." In Personal Recollections of the War of the Rebellion: Addresses Delivered Before the New York Commandery of the Loyal Legion of the United States, 1883-1891, ed. James Grant Wilson and Titus Munson Coan, 375-80. New York: The Commandery, 1891. Reprint, Wilmington, NC: Broadfoot Publishing, 1992.

Hedrick, David T. and Gordon Barry Davis, Jr., ed. I'm Surrounded by Methodists...Diary of John H. W. Stuckenberg, Chaplain of the 145th Pennsylvania Volunteer Infantry. Gettysburg: Thomas Publications, 1995.

Helmreich, Jonathan, ed. The Petersburg with the Army of the Potomac: The Civil War Letters of Levi Bird Duff, 105th Pennsylvania Volunteers. Jefferson, NC: McFarland \& Company, 2009.

Hill, A. F. Our Boys. The Personal Experiences of a Soldier in the Army of the Potomac. Philadelphia: John E. Potter, 1864.

History of the Fighting Fourteenth. N.p.: n.p., 1911.

Holcomb, Julie, ed. Southern Sons, Northern Soldiers: The Civil War Letters of the Remley Brothers, 22nd Iowa Infantry. With an introduction by Steven A. Woodworth. DeKalb: Northern Illinois University Press, 2004.

Hogan, Edwin P., ed. Waiting for Jacob: A Civil War Story. Latrobe, PA: Saint Vincent College Center for North Appalachian Studies, 2000.

Hopkins, Charles A. The March to the Sea. Providence: The Society, 1885. In Personal Narratives of the War of the Rebellion, Being Papers Read Before the Rhode Island Soldiers and Sailors Historical Society, vol. V. Wilmington, NC: Broadfoot Publishing, 1993.

Horton, Joshua H. and Solomon Teverbaugh. History of the Eleventh Regiment (Ohio Volunteer Infantry), Containing the Military Record, So Far as it is Possible to Obtain It, of Each Officer and Enlisted Man in the Command, a List of Deaths, an Account of the Veterans, Incidents of Field and Camp, Names of Three Months' Volunteers, Compiled from the Official Records. Dayton: W. H. Shuey, 1866.

Houghton, Edwin B. The Campaigns of the Seventeenth Maine. Portland, ME: Short \& Loring, 1866.

[Howe, Henry Warren.] Passages from the Life of Henry Warren Howe: Consisting of Diary and Letters Written During the Civil War, 1861-1865. Lowell: CourierCitizen Press, 1899.

Howe, James H. "The Loyal Legion." In Glimpses of the Nation's Struggle: A Series of 
Papers Read Before the Minnesota Commandery of the Loyal Legion of the United States, 2d Series. Ed. Edward D. Neill, 280-88. St. Paul: St. Paul Book and Stationery Company, 1890. Reprint, Wilmington, NC: Broadfoot Publishing, 1992.

Hunter, Lloyd A., ed. For Duty and Destiny: The Life and Civil War Diary of Hoosier Soldier and Educator William Taylor Stott. Indianapolis: Indiana Historical Society Press, 2010.

Hunter, Robert. "Historical Sketch." In Album: Portraits of Companions of the Commandery of the State of Ohio, Military Order of the Loyal Legion of the United States, 1-6. Cincinnati: n.p., 1893. Reprint, Wilmington, NC: Broadfoot Publishing, 1993.

Hurst, Samuel. Journal-History of the Seventy-Third Ohio Volunteer Infantry. Chillicothe: n.p., 1866.

Hyde, William L. History of the One Hundred and Twelfth Regiment N.Y. Volunteers. Fredonia: W. McKinstry, 1865.

Illisevich, Robert and Jonathan Helmreich, ed. The Civil War Diaries of Seth Waid III. Meadville, PA: Crawford County Historical Society, 1993.

Jackson, Harry F. and Thomas E. O'Donnell, ed. Back Home in Oneida: Hermon Clarke and His Letters. Syracuse: Syracuse University Press, 1965.

James, Garth W. "The Assault on Fort Wagner." In War Papers: Being papers Read Before the Commandery of the State of Wisconsin, Military Order of the Loyal Legion of the United States, vol. I, 9-30. Milwaukee: n.p., 1891. Reprint, Wilmington, NC: Broadfoot Publishing, 1993.

Jordan, William B., ed. The Civil War Journals of John Mead Gould 1861-1865. Baltimore: Butternut and Blue, 1997.

Judson, Amos. History of the Eighty-Third Regiment Pennsylvania Volunteers. Ed. James A. Trulock and Alice Rains Trulock. Erie: B.F.H. Lynn, 1865. Reprint, Arlington: Stonewall House, 1985.

Kaiser, Leo M., ed. "The Civil War Diary of Florison D. Pitts." Mid-America: An Historical Review 40 no.1 (January 1958): 22-63.

Kellogg, Mary, comp. Army Life of an Illinois Soldier: Including a Day-by-Day Record of Sherman's March to the Sea. With a foreword by John Y. Simon. Washington, D.C.: Globe Printing Company, 1906. Reprint, Carbondale: Southern Illinois University Press, 1996. 
Kemper, Andrew C. "The Night After the Battle." In Sketches of War History, 18611865: Papers Read Before the Ohio Commandery of the Military Order of the Loyal Legion of the United States, 1883-1886, Vol. I, 37-53. Cincinnati: Robert Clarke \& Co., 1888. Reprint, Wilmington, NC: Broadfoot Publishing, 1991.

Kerr, D. C. "The Loyal Legion." In Glimpses of the Nation's Struggle: Papers Read Before the Minnesota Commandery of the Military Order of the Loyal Legion of the United States, 1889-1892, 3rd Series, 132-34. St. Paul: D.D. Merrill Company, 1893. Reprint, Wilmington, NC: Broadfoot Publishing, 1992.

Kinnear, John R. History of the Eighty-Sixth Regiment Illinois Volunteer Infantry During Its Term of Service. Chicago: Tribune Company's Book and Job Printing Office, 1866.

Kiper, Richard L., ed. Dear Catharine: Dear Taylor: The Civil War Letters of a Union Soldier and His Wife. Lawrence: University Press of Kansas, 2002.

Larimer, Charles F., ed. Love and Valor: Intimate Civil War Letters Between Captain Jacob and Emeline Ritner. Western Springs, IL: Sigourney Press, 2000.

Lewis, Osceola. History of the One Hundred and Thirty-Eighth Regiment, Pennsylvania Volunteer Infantry. Norristown: Wills, Iredell \& Jenkins, 1866.

Life of David Bell Birney, Major-General United States Volunteers. Philadelphia: King \& Baird, 1867.

Logan, John A. The Great Conspiracy: Its Origin and History. New York: A. R. Hart, 1866.

Longacre, Edward G., ed. From Antietam to Fort Fisher: The Civil War Letters of Edward King Wightman, 1862-1865. Rutherford, NJ: Fairleigh Dickinson University Press, 1986.

Lowe, David W., ed. Meade's Army: The Private Notebooks of Lt. Col. Theodore Lyman. Kent, OH: Kent State University Press, 2007.

Mannis, Jedediah and Galen R. Wilson, ed. Bound to Be a Soldier: The Letters of Private James T. Miller, 111th Pennsylvania Infantry, 1861-1864. Knoxville: University of Tennessee Press, 2001.

McLaughlin, Florence C., ed. "'Dear Sister Jennie--Dear Brother Jacob': The Correspondence Between a Northern Soldier and His Sister in Mechanicsburg, Pennsylvania, 1861-1864." Western Pennsylvania Historical Magazine 60 no. 2 (April 1977): 109-143.

Meade, George Gordon, ed. The Life and Letters of George Gordon Meade, Major- 
General United States Army 2 vols. New York: Charles Scribner's Sons, 1913.

Merrill, Samuel. The Campaigns of the First Maine and District of Columbia Cavalry. Portland, ME: Bailey and Noyes, 1866.

Miller, Brian Craig, ed. "A Punishment on the Nation": An Iowa Soldier Endures the Civil War. Kent, OH: Kent State University Press, 2012.

Mitchell, Charles D. "Field Notes of the Selma Campaign." In Sketches of War History 1861-1865: Papers Prepared for the Commandery of the State of Ohio, Military Order of the Loyal Legion of the United States, 1903-1908, vol. VII, ed. Theodore F. Allen, Edward S. McKee, and J. Gordon Taylor, 174-194. Cincinnati: Monfort \& Company, 1908. Reprint, Wilmington, NC: Broadfoot Publishing, 1992.

Mitchell, Thomas. The Kindred Organizations: The Society of the Cincinnati and the Military Order of the Loyal Legion of the United States. In Civil War Papers of the California Commandery of the Military Order of the Loyal Legion of the United States, 17-24. Wilmington, NC: Broadfoot Publishing, 1995.

Monroe, J. Albert. Reminiscences of the War of the Rebellion of 1861-5. Providence: N. Bangs Williams \& Co., 1881. In Personal Narratives of the War of the Rebellion, Being Papers Read before the Rhode Island Soldiers and Sailors Historical Society, vol. II. Wilmington, NC: Broadfoot Publishing, 1993.

Moore, James P. "War's First Rude Alarm in 1861." In Glimpses of the Nation's Struggle: Papers Read Before the Minnesota Commandery of the Military Order of the Loyal Legion of the United States, 1892-1897, 4th Series, 8-23. St. Paul: H. L. Collins, 1989. Reprint, Wilmington, NC: Broadfoot Publishing, 1992.

Morgan, Thomas J. Reminiscences of Service with Colored Troops in the Army of the Cumberland. Providence: The Society, 1885. In Personal Narratives of the War of the Rebellion, Being Papers Read Before the Rhode Island Soldiers and Sailors Historical Society, vol. V. Wilmington, NC: Broadfoot Publishing, 1993.

Mowris, J. A. A History of the One Hundred Seventeenth Regiment, N.Y. Volunteers (Fourth Oneida) from Date of Its Organization, August 1862, Till That of Its Muster Out, June, 1865. Harford, CT: Case, Lockwood, and Company, 1866.

[Muffly, J.W., ed.] The Story of Our Regiment: A History of the 148th Pennsylvania Vols. Des Moines: Kenyon Printing \& Mf. Co., 1904.

Murphey, Thomas G. Four Years in the War: The History of the First Regiment of Delaware Veteran Volunteers (Infantry), Containing an Account of Marches, Battles, Incidents, Promotions, and Names of All the Officers and Men Who Have Been Connected with the Regiment from Its Organization in 1861 to the Close of the War. Philadelphia: James S. Claxton, 1866. 
Nanzig, Thomas P., ed. The Badax Tigers: From Shiloh to the Surrender with the 18th Wisconsin Volunteers. Lanham, MD: Rowman \& Littlefield, 2002.

Nation, Richard F. and Stephen E. Towne, eds. Indiana's Civil War: The Civil War in Documents. Athens: Ohio University Press, 2009.

Norton, Henry Allyn. "Colored Troops in the War of the Rebellion." In Glimpses of the Nation's Struggle: Papers Read Before the Minnesota Commandery of the Military Order of the Loyal Legion of the United States, 5th Series, 59-73. St. Paul: Review Publishing, 1903. Reprint, Wilmington, NC: Broadfoot Publishing, 1992.

Norton, Oliver Willcox. Army Letters 1861-1865, Being Extracts from Private Letters to Relatives and Friends from a Soldier in the Field During the Late Civil War with an Appendix Containing Copies of Some Official Documents, Papers and Addresses of a Later Date. Chicago: O. L. Deming, 1903.

O'Shaughnessy, Mary Searing, ed. Alonzo's War: Letters from a Young Civil War Soldier. Madison, NJ: Fairleigh Dickinson University Press, 2012.

Paddock, George L. "The Beginnings of an Illinois Volunteer Regiment in 1861. In Military Essays and Recollections: Papers Read Before the Commandery of the State of Illinois, Military Order of the Loyal Legion of the United States, vol. II, 253-267. Chicago: A. C. McClurg and Company, 1894. Reprint, Wilmington, NC: Broadfoot Publishing, 1992.

Palm, Ronn, Richard Sauers, and Patrick A. Schroeder, comp. and ed. The Bloody 85th: The Letters of Milton McJunkin, a Western Pennsylvania Soldier in the Civil War. Lynchburg, VA: Schroeder Publications, 2002.

Patrick, Jeffrey L., ed. Three Years with Wallace's Zouaves: The Civil War Memoirs of Thomas Wise Durham. Macon, GA: Mercer University Press, 2003.

Patrick, Jeffrey L. and Robert J., Willey. Fighting for Liberty and Right: The Civil War Diary of William Bluffton Miller, First Sergeant, Company K, Seventy-Fifth Indiana Volunteer Infantry. Knoxville: University of Tennessee Press, 2005.

Pellett, Elias P. History of the 114th Regiment New York State Volunteers, Containing a Perfect Record of Its Services, Embracing All Its Marches, Campaigns, Battles, Sieges, and Sea-Voyages, with a Biographical Sketch of Each Officer, and a Complete Register of the Regiment, Wherein Appears the Name of Every Officer and Enlisted Man who has Ever Belonged to the Same, with Full Remarks Relating Thereto. Norwich: Telegraph \& Chronicle Power Press Print Co., 1866.

Perkins, Howard Cecil, ed. Northern Editorials on Secession. 2 vols. New York: D. 
Appleton-Century Company, 1942.

Petty, A. W. M. History of the Third Missouri Cavalry from Its Organization in Palmyra, Missouri, 1861, up to November Sixth, 1864, with an Appendix and Recapitulation. Little Rock: J. Wm. Denby, 1865.

Pierce, Lyman B. History of the Second Iowa Cavalry, Containing a Detailed Account of Its Operation, Marches, and Battles in Which It Has Participated; also, a Complete Roster of Each Company. Burlington, IA: Hawk-Eye Printing Establishment, 1865.

Popchock, Barry, ed. Soldier Boy: The Civil War Letters of Charles O. Musser, 29th Iowa. Iowa City: University of Iowa Press, 1995.

Post, Lydia Minturn, ed. Soldiers' Letters from Camp, Battle-field and Prison. New York: Bunce \& Huntington, 1865.

Powers, George W. The Story of the Thirty-Eighth Regiment of Massachusetts Volunteers. Cambridge: Dakin and Metcalf, 1866.

Reyburn, Philip J. and Terry L. Wilson, eds. "Jottings from Dixie": The Civil War Dispatches of Sergeant Major Stephen F. Fleharty, U.S.A. Baton Rouge: Louisiana State University Press, 1999.

Rickard, James H. Services with Colored Troops in Burnside's Corps. Providence: The Society, 1894. In Personal Narratives of the Events of the War of the Rebellion, Being Papers Read Before the Rhode Island Soldiers and Sailors Historical Society. Wilmington, NC: Broadfoot Publishing, 1993.

Riddle, Francis A. "The Soldier's Place in Civilization." In Military Essays and Recollections: Papers Read Before the Commandery of the State of Illinois, Military Order of the Loyal Legion of the United States, vol. II, 515-35. Chicago: A. C. McClurg and Company, 1894. Reprint, Wilmington, NC: Broadfoot Publishing, 1992.

Robertson, James I., Jr., ed. The Civil War Letters of General Robert McAllister. New Brunswick, NJ: Rutgers University Press, 1965. Reprint, Baton Rouge: Louisiana State University Press, 1998.

Rogers, William H. History of the One Hundred and Eighty-Ninth Regiment of New-York Volunteers. New York: John A. Gray \& Green, 1865.

Roosevelt, Theodore and Henry Cabot Lodge. Hero Tales from American History: Or the Story of Some Americans Who Showed That They Knew How to Live and How to Die. New York: Charles Scribner's Sons, 1906. 
Rowell, Eliphalet. "Six Months in the Military Department of Virginia and North Carolina." In War Papers Read Before the Commandery of the State of Maine, Military Order of the Loyal Legion of the United States, Vol. II, 41-60. Portland, ME: Lefavor-Tower Company, 1902. Reprint, Wilmington, NC: Broadfoot Publishing, 1992.

Russ, William A., Jr., ed. "Civil War Letters Concerning Members of Co. G, 174th Reg., P.V.I." Susquehanna University Studies V no. 3 (1955): 179-220.

Sands, Francis P. B. Military Order of the Loyal Legion of the United States Commandery of the District of Columbia: War Papers 86: The Loyal Legion and the Civil War. In War Papers: Being Papers Read Before the Commandery of the District of Columbia, Military Order of the Loyal Legion of the United States, vol. 4, 263-78. Wilmington, NC: Broadfoot Publishing, 1993.

Sauers, Richard A., ed. The Civil War Journal of Colonel William J. Bolton, 51st Pennsylvania, April 20, 1861-August 2, 1865. Conshohocken, PA: Combined Publishing, 2000.

Savage, James W. "The Loyal Element in North Carolina During the War." In Civil War Sketches and Incidents: Papers Read by Companions of the Commandery of the State of Nebraska, Military Order of the Loyal Legion of the United States, 1-5. Omaha: The Commandery, 1902. Reprint, Wilmington, NC: Broadfoot Publishing, 1992.

Severance, M. J. "The Results of War." In Glimpses of the Nation's Struggle: A Series of Papers Read Before the Minnesota Commandery of the Loyal Legion of the United States, 2d Series. Ed. Edward D. Neill, 367-80. St. Paul: St. Paul Book and Stationery Company, 1890. Reprint, Wilmington, NC: Broadfoot Publishing, 1992.

Sewall, John A. "Echoes from Life in Camp." In War Papers Read Before the Commandery of the State of Maine, Military Order of the Loyal Legion of the United States vol. IV, 73-89. Portland, ME: Lefavor-Tower, 1915. Reprint, Wilmington, NC: Broadfoot Publishing, 1992.

Sibley, Henry H. "Remarks." In Glimpses of the Nation's Struggle: A Series of Papers Read Before the Minnesota Commandery of the Loyal Legion of the United States, 2d Series. Ed. Edward D. Neill, 223-26. St. Paul: St. Paul Book and Stationery Company, 1890. Reprint, Wilmington, NC: Broadfoot Publishing, 1992.

Silber, Nina and Mary Beth Stevens, eds. Yankee Correspondence: Civil War Letters Between New England Soldiers and the Home Front. Charlottesville: University Press of Virginia, 1996.

Simmons, L. A. History of the 84th Reg't Ill. Vols. Macomb: Hampton Brothers, 1866. 
Soper, E. B. "Our Order of the Loyal Legion." In War Sketches and Incidents as Related by Companions of the Iowa Commandery of the Military Order of the Loyal Legion of the United States, vol. I, 322-25. Des Moines: Press of P. C. Kenyon, 1893. Reprint, Wilmington, NC: Broadfoot Publishing, 1994.

Sperry, A. F. History of the 33d Iowa Volunteer Infantry Regiment 1863-6. Ed. Gregory J. W. Urwin and Cathy Kunzinger Urwin. 1866. Reprint, Fayetteville: University of Arkansas Press, 1999.

Stevenson, Thomas M. History of the 78th Regiment OVVI, from Its "Muster-In" to Its "Muster-Out," Comprising its Organization, Marches, Campaigns, Battles, and Skirmishes. Zanesville: Hugh Dunne, 1865.

Styple, William B., ed. Writing and Fighting the Civil War: Soldier Correspondence to the New York Sunday Mercury. Kearny, NJ: Belle Grove Publishing, 2004.

Sumbardo, C. L. "Incidents of Prison Life, with Causes of Confederate Cruelty." In In Glimpses of the Nation's Struggle: Papers Read Before the Minnesota Commandery of the Military Order of the Loyal Legion of the United States, 1889-1892, 3rd Series, 347-77. St. Paul: D.D. Merrill Company, 1893. Reprint, Wilmington, NC: Broadfoot Publishing, 1992.

Swedberg, Claire E., ed. Three Years with the 92d Illinois: The Civil War Diary of John M. King. Mechanicsville, PA: Stackpole Books, 1999.

Sweeney, Charles H. "Our Friend--The Enemy." In War Sketches and Incidents as Related by the Companions of the Iowa Commandery, Military Order of the Loyal Legion of the United States, vol. II, 478-87. Des Moines: Iowa Commandery, 1898. Reprint, Wilmington, NC: Broadfoot Publishing, 1994.

Sylvester, Loran Lutes, ed. "The Civil War Letters of Charles Harding Cox." Indiana Magazine of History 68 no. 1 (March 1972): 24-78.

Vanderslice, Catherine H. The Civil War Letters of George Washington Beidelman. New York: Vantage Press, 1978.

Walkley, Stephen. History of the Seventh Connecticut Volunteer Infantry, Hawley's Brigade, Terry's Division, Tenth Army Corps 1861-1865. N.p.: n.d.

War Diary and Letters of Stephen Minot Weld 1861-1865. N.p.: Riverside Press, 1912.

Watson, Ronald, ed. From Ashby to Andersonville: The Civil War Diary and Personal Reminiscences of Private George A. Hitchcock, 21st Massachusetts Infantry Regiment. Capmbell, CA: Savas Publishing, 1997. 
Whitman, Walt. The Correspodence: Volume I: 1842-1867. Ed. Edwin Haviland Miller. New York: New York University Press, 1961.

Whitney, J. H. E. The Hawkins Zouaves: (Ninth N.Y.V.) Their Battles and Marches. New York: The Author, 1866.

Wilcox, Lyman. "The South in War Times." In War Papers: Being Papers Read Before the Commandery of the State of Michigan, Military Order of the Loyal Legion of the United States, 12-38. Detroit: The Commandery, 1898. Reprint, Wilmington, NC: Broadfoot Publishing, 1993.

Wilkin, Jacob W. "Vicksburg." In Military Essays and Recollections: Papers Read Before the Commandery of the State of Illinois, Military Order of the Loyal Legion of the United States, Vol. IV, 215-37. Chicago: Cozzens \& Beaton, 1907. Reprint, Wilmington, NC: Broadfoot Publishing, 1992.

Wilson, Eugene M. "The Blessings of War." In Glimpses of the Nation's Struggle: A Series of Papers Read Before the Minnesota Commandery of the Military Order of the Loyal Legion of the United States, 167-178. St. Paul: St. Paul Book and Stationery Company, 1887. Reprint, Wilmington, NC: Broadfoot Publishing, 1992.

Wilson, Henry. History of the Rise and Fall of the Slave Power in America. 3 vols. Boston: Houghton Mifflin and Company, 1872-1877.

Wittenberg, Eric J., ed. "We Have It Damn Hard Out Here": The Civil War Letters of Sergeant Thomas W. Smith, 6th Pennsylvania Cavalry. Kent, OH: Kent State University Press, 1999.

Wood, George L. The Seventh Regiment, A Record. New York: James Miller, 1865.

Wood, Wales W. A History of the Ninety-Fifth Regiment, Illinois Infantry Volunteers from its Organization in the Fall of 1862 Until its Final Discharge from the United States Service, in 1865. Chicago: Tribune Company's Book and Job Printing Press, 1865.

Woodward, E. M. Our Campaigns; or, the Marches, Bivouacs, Battles, Incidents of Camp Life, and History of Our Regiment During Its Three Year Term of Service. Philadelphia: John E. Potter, 1865.

Zimm, John, ed. This Wicked Rebellion: Wisconsin Soldiers Write Home. Madison: Wisconsin Historical Society Press, 2012.

\section{Secondary Works}

\section{Books and Articles}


Ash, Stephen V. "Civil War Exodus: The Jews and Grant's General Order No. 11." In Jews in the Civil War: A Reader, ed. Jonathan D. Sarna and Adam Mendelsohn, 363-84. New York: New York University Press, 2010.

Ashworth, John. "Free Labor, Wage Labor, and Slave Power: Republicanism and the Republican Party in the 1850s." In The Market Revolution in America: Social, Political, and Religious Expressions, 1800-1880. Ed. Melvyn Stokes and Stephen Conway, 128-48. Charlottesville: University of Virginia Press, 1996.

Ayers, Edward L. "What Caused the Civil War." In What Caused the Civil War: Reflections on the South and Southern History, 131-44. New York: W.W. Norton, 2005.

Beatie, Russel H. Army of the Potomac: Volume III: McClellan's First Campaign, March 1862-May 1862. New York: SavasBeatie, 2007.

Berry, Stephen W., II. All That Makes a Man: Love and Ambition in the Civil War South. New York: Oxford University Press, 2003.

Berwanger, Eugene H. The Frontier Against Slavery: Western Anti-Negro Prejudice and the Slavery Extension Controversy. Urbana: University of Illinois Press, 1967.

Blight, David W. Race and Reunion: The Civil War in American Memory. Cambridge: Belknap Press of Harvard University Press, 2001.

Boucher, Chauncey S. "In Re That Aggressive Slaveocracy." Mississippi Valley Historical Review 8 no. 1/2 (June-September 1921): 13-79.

Bradbury, John F. "'Good Water \& Wood but the Country is a Miserable Botch': Flatland Soldiers Confront the Ozarks." Missouri Historical Review XC, no. 2 (January 1996): 166-86.

Buck, Paul H. The Road to Reunion 1865-1900. Boston: Little, Brown, 1937.

Bunker, Gary L. and John J. Appel. "'Shoddy' Antisemitism and the Civil War." In Jews in the Civil War: A Reader, ed. Jonathan D. Sarna and Adam Mendelsohn, 31134. New York: New York University Press, 2010.

Burchard, Peter. One Gallant Rush: Robert Gould Shaw and His Brave Black Regiment. New York: St. Martin's Press, 1965.

Carmichael, Peter S. "We Respect a Good Soldier, No Matter What Flag He Fought Under: The 15th New Jersey Remembers Spotsylvania." In The Spotsylvania Campaign, ed. Gary W. Gallagher, 203-222. Chapel Hill: University of North Carolina Press, 1998. 
Cecere, David A. "Carrying the Home Front to War: Soldiers, Race, and New England Culture During the Civil War." In Union Soldiers and the Northern Home Front: Wartime Experience, Postwar Adjustment, ed. Paul A. Cimbala and Randall M. Miller, 293-326. New York: Fordham University Press, 2002.

Chambers, Thomas A. Memories of War: Visiting Battlegrounds and Bonefields in the Early American Republic. Ithaca, NY: Cornell University Press, 2012.

Cheng, Eileen Ka-May. The Plain and Noble Garb of Truth: Nationalism and Impartiality in American Historical Writing, 1784-1860. Athens: University of Georgia Press, 2008.

Cuccia, Phillip. "'Gorillas' and White Glove Gents: Union Soldiers in the Red River Campaign." Louisiana History: The Journal of the Louisiana Historical Association 36, no. 4 (Autumn 1995): 413-30.

Cunliffe, Marcus. Soldiers \& Civilians: The Martial Spirit in America 1776-1865. New York: The Free Press, 1968.

Cushman, Stephen. Bloodu Promenade: Reflections of a Civil War Battle. Charlottesville: University of Virginia Press, 1999.

Dailey, Jane Elizabeth. Before Jim Crow: The Politics of Race in Postemancipation Virginia. Chapel Hill: University of North Carolina Press, 2000.

Davis, David Brion. The Slave Power Conspiracy and the Paranoid Style. Baton Rouge: Louisiana State University Press, 1969.

DeGruccio, Michael. "Letting the War Slip Through Our Hands: Material Culutre and the Weakness of Words in the Civil War Era." In Weirding the War: Stories from the Civil War's Ragged Edges, ed. Stephen Berry, 15-35. Athens: University of Georgia Press, 2011.

Dornbusch, Charles. Military Bibliography of the Civil War, 3 vols. New York: New York Public Library, 1961-1972.

Downs, Jim. Sick from Freedom: African American Illness and Suffering During the Civil War and Reconstruction. Oxford: Oxford University Press, 2012.

Duncan, Russell. Where Death and Glory Meet: Robert Gould Shaw and the 54th Massachusetts Infantry. Athens: University of Georgia Press, 1999.

Eby, Cecil D., Jr. "Porte Crayon": The Life of David Hunter Strother. Chapel Hill: University of North Carolina Press, 1960. 
Fabian, Ann. The Unvarnished Truth: Personal Narratives in Nineteenth-Century America. Berkeley: University of California Press, 2000.

Fahs, Alice. The Imagined Civil War: Popular Literature of the North and South, 1861 1865. Chapel Hill: University of North Carolina Press, 2001.

Felton, Silas. Military Bibliography of the Civil War Vol. 4, Revised. Dayton: Morningside Books, 2003.

Fields, Barabara J. "Ideology and Race in American History." In Region, Race, and Reconstruction: Essays in Honor of C. Vann Woodward, ed. J. Morgan Kousser and James M. McPherson, 143-177. New York: Oxford University Press, 1982.

Fleche, Andre. "'Shoulder to Shoulder as Comrades Tried': Black and White Union Veterans and Civil War Memory." Civil War History: A Journal of the Middle Period 51, no. 2 (June 2005): 175-201.

------. The Revolution of 1861: The American Civil War in the Era of Nationalist Conflict. Chapel Hill: University of North Carolina Press, 2012.

Foner, Eric. Free Soil, Free Labor, and Free Men: The Ideology of the Republican Party Before the Civil War. New York: Oxford University Press, 1970.

Foote, Lorien. The Gentlemen and the Roughs: Violence, Honor, and Manhood in the Union Army. New York: New York University Press, 2010.

Foster, Gaines M. Ghosts of the Confederacy: Defeat, the Lost Cause, and the Emergence of the New South, 1865 to 1913. New York: Oxford University Press, 1987.

Frank, Joseph Allan. With Ballot and Bayonet: The Political Socialization of American Civil War Soldiers. Athens: University of Georgia Press, 1998.

Frederickson, George M. The Black Image in the White Mind: The Debate on AfroAmerican Character and Destiny, 1817-1914. New York: Harper and Row, 1971. Reprint, Hanover, NH: Wesleyan University Press, 1987.

Freehling, William W. The Road to Disunion: Volume I: Secessionists at Bay, 17761854. New York: Oxford University Press, 1990.

--------. The Road to Disunion: Volume II: Secessionists Triumphant, 1854-1861. New York: Oxford University Press, 2007.

Gallagher, Gary W. Causes Won, Lost, and Forgotten: How Hollywood and Popular Art Shape What We Know About the Civil War. Chapel Hill: University of North Carolina Press, 2008. 
--------. The Union War. Cambridge: Harvard University Press, 2011.

Gallagher, Gary W. and Alan T. Nolan, eds. The Myth of the Lost Cause and Civil War History. Bloomington: University of Indiana Press, 2000.

Gallman, J. Matthew. Mastering Wartime: A Social History of Philadelphia During the Civil War. New York: Cambridge University Press, 1990.

Gannon, Barbara A. The Won Cause: Black and White Comradeship in the Grand Army of the Republic. Chapel Hill: University of North Carolina Press, 2011.

Gara, Larry. "Slavery and the Slave Power: A Crucial Distinction." Civil War History 15 no. 1 (March 1969): 5-18.

Gilmore, Glenda. Gender and Jim Crow: Women and the Politics of White Supremacy in North Carolina, 1896-1920. Chapel Hill: University of North Carolina Press, 2000.

Glickstein, Jonathan A. American Exceptionalism, American Anxiety: Wages, Competition, and Degraded Labor in the Antebellum United States. Charlottesville: University of Virginia Press, 2002.

Gordon, Lesley J. "All Who Went into That Battle Were Heroes: Remembering the 16th Regiment Connecticut Volunteers at Antietam." In The Antietam Campaign, ed. Gary W. Gallagher, 169-191. Chapel Hill: University of North Carolina Press, 1999.

Green, James N. "The Rise of Book Publishing." In The History of the Book in America: Volume 2: An Extensive Republic: Print, Culture, and Society in the New Nation 1790-1840, ed. Robert A. Goss and Mary Kelley, 75-127. Chapel Hill: University of North Carolina Press, 2010.

Gross, Ariela J. What Blood Won't Tell: A History of Race on Trial in America. Cambridge: Harvard University Press, 2008.

Hale, Grace Elizabeth. Making Whiteness: The Culture of Segregation in the South, 1890-1940. New York: Pantheon Books, 1998.

Harris, M. Keith. "Slavery, Emancipation, and Veterans of the Union Cause: Commemorating Freedom in the Era of Reconciliation, 1885-1915." Civil War History: A Journal of the Middle Period 53 no. 3 (September 2007): 264-90.

Hess, Earl J. Liberty, Virtue, and Progress: Northerners and Their War for the Union, 2nd ed. New York: Fordham University Press, 1997.

Higginbotham, Don. George Washington and the American Military Tradition. Athens: 
University of Georgia Press, 1985.

Hofstadter, Richard. "The Paranoid Style in American Politics." In The Paranoid Style in American Politics and Other Essays, 3-40. New York: Vintage Books, 1967.

Hubben, Hubert W. Civil War Iowa and the Copperhead Movement. Ames: Iowa State University Press, 1980.

Humphreys, Margaret. Intensely Human: The Health of the Black Soldier in the American Civil War. Baltimore: The Johns Hopkins University Press, 2008.

Hunt, Robert. The Good Men Who Won the War: Army of the Cumberland Veterans and Emancipation Memory. Tuscaloosa: University of Alabama Press, 2010).

Inscoe, John C. "'Moving Through Deserter Country': Fugitive Accounts of the Inner Civil War in Southern Appalachia." In The Civil War in Appalachia: Collected Essays, ed. Kenneth W. Noe and Shannon H. Wilson, 158-86. Knoxville: University of Tennessee Press, 1997.

Jackson, William J. New Jerseyans in the Civil War: For Union and Liberty. New Brunswick, NJ: Rutgers University Press, 2000.

Jimmerson, Randall. The Private Civil War: Popular Thought During the Sectional Conflict. Baton Rouge: Louisiana State University Press, 1988.

Jordan, Irvin L. Black Confederates and Afro-Yankees in Civil War Virginia. Charlottesville: University Press of Virginia, 1995.

Kaser, David. Books and Libraries in Camp and Battle: The Civil War Experience. Westport, CT: Greenwood Press, 1984.

Keehn David C. Knights of the Golden Circle: Secret Empire, Southern Secession, Civil War. Baton Rouge: Louisiana State University Press, 2013.

Klement, Frank L. The Copperheads in the Middle West. Chicago: University of Chicago Press, 1960.

Koschnik, Albrecht. "Let a Common Interest Bind Us Together": Associations, Partisanship, and Political Culture in Philadelphia, 1775-1840. Charlottesville: University of Virginia Press, 2007.

Laurie, Bruce. "Labor and Labor Organization." In A History of the Book in America: Volume 3: The Industrial Book 1840-1880, ed. Scott E. Casper, Jeffrey D. Groves, Stephen W. Nissenbaum, and Michael Winship, 70-89. Chapel Hill: University of North Carolina Press, 2007. 
Lawson, Melinda. "Imaging Slavery: Representations of the Peculiar Institution on the Northern Stage, 1776-1860." Journal of the Civil War Era 1 no. 1 (March 2011): 25-55.

Linderman, Gerald. Embattled Courage: The Experience of Combat in the American Civil War. New York: Free Press, 1987.

Link, William A. Roots of Secession: Slavery and Politics in Antebellum Virginia. Chapel Hill: University of North Carolina Press, 2003.

Lott, Eric. Love and Theft: Blackface Minstrelsy and the American Working Class. New York: Oxford University Press, 1993.

Luskey, Brian P. On the Make: Clerks and the Quest for Capital in Nineteenth-Century America. New York: New York University Press, 2010.

Mahan, Harold E. Benson J. Lossing and Historical Writing in the United States 18301890. Westport, CT: Greenwood Press, 1996.

Mahar, William J. Behind the Burnt Cork Mask: Early Blackface Minstrelsy and Antebellum Popular Culture. Urbana: University of Illinois Press, 1999.

Manning, Chandra. What This Cruel War Was Over: Soldiers, Slavery, and the Civil War. New York: Knopf, 2007.

McConnell, Stuart. Glorious Contentment: The Grand Army of the Republic, 1865-1900. Chapel Hill: University of North Carolina Press, 1992.

McPherson, James M. For Cause and Comrades: Why Men Fought in the Civil War. New York: Oxford University Press, 1997.

Meier, Kathryn Shively. Nature's Civil War: Common Soldiers and the Environment in 1862 Virginia. Chapel Hill: University of North Carolina Press, 2013.

Milroy, Elizabeth. "Avenue of Dreams: Patriotism and the Spectator at Philadelphia's Great Central Sanitary Fair." In Making and Remaking Pennsylvania's Civil War, ed. William Blair and William Pencak, 23-58. University Park: Pennsylvania State University Press, 2001.

Mitchell, Reid. Civil War Soldiers. New York: Viking, 1988.

--------- "Not the General but the Soldier: The Study of Civil War Soldiers." In Writing the Civil War: The Quest to Understand, ed. James M. McPherson and William J. Cooper, Jr., 81-95. Columbia: University of South Carolina Press, 1998.

Myers, John L. "The Writing of History of the Rise and Fall of the Slave Power in 
America." Civil War History 31 no. 2 (June 1985): 144-62.

Myers, Minor, Jr. Liberty Without Anarchy: A History of the Society of the Cincinnati. Charlottesville: University Press of Virginia, 1993.

Nalty, Sean. "'Come Weal, Come Woe, I am with the Anti-Slavery Party': Federalism and the Formation of the Pennsylvania Union Party." In A Political Nation: New Directions in Mid-Nineteenth-Century American Political History, ed. Gary W. Gallagher and Rachel A. Shelden, 143-66. Charlottesville: University of Virginia Press, 2012.

Neeley, Mark E., Jr. The Boundaries of American Political Culture in the Civil War Era. Chapel Hill: University of North Carolina Press, 2005.

Neff, John R. Honoring the Civil War Dead: Commemoration and the Problem of Reconciliation. Lawrence: University Press of Kansas, 2005.

Nelson, Megan Kate. Ruin Nation: Destruction and the American Civil War. Athens: University of Georgia Press, 2012.

Oakes, James. Freedom National: The Destruction of Slavery in the United States, 18611865. New York: Norton, 2012.

O'Malley, Michael. "Rags, Blacking, and Paper Soldiers: Money and Race in the Civil War." In The Cultural Turn in U.S. History: Past, Present, and Future, ed. James W. Cook, Lawrence B. Glickman, and Michael O'Malley, 95-120. Chicago: University of Chicago Press, 2008.

Orr, Timothy. "'A Viler Enemy in Our Rear': Pennsylvania Soldiers Confront the North's Antiwar Movement." In The View from the Ground: Experiences of Civil War Soldiers, ed. Aaron-Sheehan Dean, 171-98. Lexington: University Press of Kentucky, 2007.

Osterweis, Rollin G. The Myth of the Lost Cause 1865-1900. New York: Archon Books, 1973.

Pressly, Thomas J. Americans Interpret Their Civil War. Princeton: Princeton University Press, 1954.

Prokopowicz, Gerald J. All for the Regiment: The Army of the Ohio, 1861-1862. Chapel Hill: University of North Carolina Press, 2001.

Ramold, Steven J. Baring the Iron Hand: Discipline in the Union Army. DeKalb: Northern Illinois University Press, 2010.

Reardon, Carol. "'We Are All in This War': The 148th Pennsylvania and Home Front 
Dissension in Centre County During the Civil War." In Union Soldiers and the Northern Home Front: Wartime Experiences, Postwar Adjustments, ed. Paul A. Cimbala and Randall M. Miller, 3-29. New York: Fordham University Press, 2002.

Richards, Leonard L. The Slave Power: The Free North and Southern Domination, 1780 1860. Baton Rouge: Louisiana State University Press, 2000.

Robertson, James I., Jr. Soldiers Blue and Gray. Columbia: University of South Carolina Press, 1988.

Roediger, David R. The Wages of Whiteness: Race and the Making of the American Working Class. With new introduction by Kathleen Cleaver. New York: Verso Books, 2007.

Rose, Anne C. Victorian America and the Civil War. Cambridge: Cambridge University Press, 1992.

Rotundo, E. Anthony. American Manhood: Transformations in Masculinity from the Revolution to the Modern Era. New York: Basic Books, 1993.

Ryan, Mary P. Cradle of the Middle Class: The Family in Oneida County, New York, 1790-1865. New York: Cambridge University Press, 1981.

Sachs, Aaron. Arcadian America: The Death and Life of an Environmental Tradition. New Haven: Yale University Press, 2013.

Sarna, Jonathan D. When General Grant Expelled the Jews. New York: Nextbook, 2012.

Saxton, Alexander. The Rise and Fall of the White Republic: Class Politics and Mass Culture in Nineteenth-Century America. New York: Verso, 1990.

---------. "Blackface Minstrelsy." In Inside the Minstrel Mask: Readings in Nineteenth-Century Blackface Minstrelsy, ed. Annemarie Bean, James V. Hatch, and Brooks McNamara, 67-85. Hanover, NH: Wesleyan University Press, 1996.

Shaffer, Donald R. After the Glory: The Struggles of Black Civil War Veterans. Lawrence: University Press of Kansas, 2004.

Shaw, Kathleen. "'Johnny Has Gone for a Soldier': Youth Enlistment in a Northern County." Pennsylvania Magazine of History and Biography 135 no. 4 (October 2011): 419-46.

Shea, William L. "A Semi-Savage State: The Image of Arkansas in the Civil War." The Arkansas Historical Quarterly 48 no. 4 (Winter 1989): 309-28. 
Sheehan-Dean, Aaron. "The Blue and the Gray in Black and White: Assessing the Scholarship on Civil War Soldiers." In The View from the Ground: Experiences of Civil War Soldiers, ed. Aaron Sheehan-Dean, 9-30. Lexington: University of Kentucky Press, 2007.

Shoaf, Dana. "'For Every Man Who Wore the Blue': The Military Order of the Loyal Legion of the United States and the Charges of Elitism After the Civil War." In Union Soldiers and the Northern Home Front: Wartime Experiences, Postwar Adjustments, ed. Paul A. Cimbala and Randall M. Miller, 463-81. New York: Fordham University Press, 2002.

Silber, Nina. Gender and the Sectional Conflict. Chapel Hill: University of North Carolina Press, 2008.

Simon, John. "The Obnoxious Order." In Jews in the Civil War: A Reader, ed. Jonathan D. Sarna and Adam Mendelsohn,353-62. New York: New York University Press, 2010.

Smith, Adam I. P. No Party Now: Politics in the Civil War North. New York: Oxford University Press, 2006.

---------. "Conservatism, Transformation, and the War for the Union." In Reconfiguring the Union: Civil War Transformations, ed. Iwan W. Morgan and Philip John Davies, 41-58. New York: Palgrave Macmillan, 2013.

Smith, Michael Thomas. "Abraham Lincoln, Manhood, and Nineteenth-Century American Political Culture." In This Distracted and Anarchical People: New Answers for Old Questions About the Civil War-Era North, ed. Andrew L. Slap and Michael Thomas Smith, 29-41. New York: Fordham University Press, 2013.

Smith, Timothy B. The Golden Age of Battlefield Preservation: The Decade of the 1890s and the Establishment of America's First Five Military Parks. Knoxville: University of Tennessee Press, 2008.

---------. A Chickamauga Memorial: The Establishment of America's First Civil War National Military Park. Knox ville: University of Tennessee Press, 2009.

Snell, Mark A. "'If They Would Know What I Know It Would Be Pretty Hard to Raise One Company in York': Recruiting, the Draft, and Society's Response in York County, Pennsylvania." In Union Soldiers and the Northern Home Front: Wartime Experiences, Postwar Adjustments, ed. Paul A. Cimbala and Randall M. Miller, 69-118. New York: Fordham University Press, 2002.

Starr, Stephen Z. "The Grand Old Regiment." Wisconsin Magazine of History 48 no. 1 (Autumn 1964): 21-31. 
Stearns, Peter N. Be a Man! Males in Modern Society, 2d ed. New York: Holmes and Miller, 1990.

Stott, Richard. Jolly Fellows: Male Milieus in Nineteenth-Century America. Baltimore: The Johns Hopkins University Press, 2009.

Tewell, Jeremy. A Self-Evident Lie: Southern Slavery and the Threat to American Freedom. Kent, OH: Kent State University Press, 2013.

Toll, Robert C. Blacking Up: The Minstrel Show in Nineteenth-Century America. New York: Oxford University Press, 1974.

Voegeli, V. Jacque. Free But Not Equal: The Midwest and the Negro During the Civil War. Chicago: University of Chicago Press, 1967.

Watts, Edward. In This Remote Country: French Colonial Culture in the Anglo-American Imagination, 1760-1860. Chapel Hill: University of North Carolina Press, 2006.

Weber, Jennifer L. Copperheads: The Rise and Fall of Lincoln's Opponents in the North. New York: Oxford University Press, 2006.

Weinberg, Adelaide. John Elliot Cairnes and the American Civil War: A Study in AngloAmerican Relations. London: Kingswood Press, 1969.

White, Jonathan W. "'For My Part I Dont Care Who Is the Elected President': The Union Army and the Elections of 1864." In This Distracted and Anarchical People: New Answers for Old Questions About the Civil War-Era North, ed. Andrew L. Slap and Michael Thomas Smith,104-122. New York: Fordham University Press, 2013.

Wiebe, Robert H. The Search for Order, 1877-1920. New York: Macmillan, 1967.

Wiley, Bell Irvin. The Life of Johnny Reb: The Common Soldier of the Confederacy. Indianapolis: Bobbs-Merrill, 1943.

--------. The Life of Billy Yank: The Common Soldier of the Union. Indianapolis: BobbsMerrill, 1952.

Wilson, Charles Reagan. Baptized in Blood: The Religion of the Lost Cause, 1865-1920. Athens: University of Georgia Press, 1980.

Winship, Michael. "Manufacturing and Book Production." In A History of the Book in America: Volume 3: The Industrial Book, 1840-1880, ed. Scott E. Casper, Jeffrey D. Groves, and Michael Winship, 40-69. Chapel Hill: University of North Carolina Press, 2007. 
---------. "The National Book Trade System: Part 1: Distribution and Trade." In $A$ History of the Book in America: Volume 3: The Industrial Book, 1840-1880, ed. Scott E. Casper, Jeffrey D. Groves, and Michael Winship, 117-130. Chapel Hill: University of North Carolina Press, 2007.

Wyatt-Brown, Bertram. Southern Honor: Ethics and Behavior in the Old South. New York: Oxford University Press, 1982.

\section{Master's Thesis}

Luebke, Peter Clayton. "'To Transmit and Perpetuate the Fruits This Victory': Union Regimental Histories, 1865-1866, and the Meaning of the Great Rebellion." MA Thesis: University of Virginia, 2007. 